\title{
Remedial Action Plan and Site DESIGN FOR STABILIZATION OF THE INACTIVE URANIUM MILL TAILINGS Sites at Slick Rock, Colorado

Remedial Action Selection Report

AtTACHMENT 2, GEOLOGY REPORT

ATTACHMENT 3, GROUND WATER HYDROLOGY REPORT

ATTACHMENT 4, WATER RESOURCES

PROTECTION STRATEgY

Final

September 1995

Appendix B of the Cooperative Agreement

No. DE-FC04-81AL16257 
INTENDED FOR PUBLIC RELEASE

This report has been reproduced from the best available copy. Available in paper copy and microfiche.

Number of pages in this report: 1735

DOE and DOE contractors can obtain copies of this report from:

Office of Scientific and Technical Information

P.O. Box 62

Oak Ridge, TN 37831

(615) 576-8401

This report is publicly available from:

National Technical Information Service

Department of Commerce

5285 Port Royal Road

Springfield, VA 22161

(703) $487-4650$ 


\title{
REMEDIAL ACTION PLAN AND SITE DESIGN FOR STABILIZATION OF THE INACTIVE URANIUM MILL TAILINGS SITES AT SLICK ROCK, COLORADO
}

Final.

September 1995

\author{
Prepared for \\ U.S. Department of Energy \\ Environmental Restoration Division \\ UMTRA Project Team \\ Albuquerque, New Mexico \\ Prepared by \\ Jacobs Engineering Group Inc. \\ Albuquerque, New Mexico
}

\section{DISCLAIMER}

\footnotetext{
This report was prepared as an account of work sponsored by an agency of the United States Government. Neither the United States Government nor any agency thereof, nor any of their employees, makes any warranty, express or implied, or assumes any legal liability or responsibility for the accuracy, completeness, or usefulness of any information, apparatus, product, or process disclosed, or represents that its use would not infringe privately owned rights. Reference herein to any specific commercial product, process, or service by trade name, trademark, manufacturer, or otherwise does not necessarily constitute or imply its endorsement, recommendation, or favoring by the United States Government or any agency thereof. The views and opinions of authors expressed herein do not necessarily state or reflect those of the United States Government or any agency thereof.
} 


\section{DISCLAIMER}

Portions of this document may be illegible in electronic image products. Images are produced from the best available original document. 


\section{EXECUTIVE SUMMARY}

\section{INTRODUCTION}

The Slick Rock uranium mill tailings sites are located near the small community of Slick Rock, in San Miguel County, Colorado. There are two designated Uranium Mill Tailings Remedial Action (UMTRA) Project sites at Slick Rock: the Union Carbide (UC) site and the North Continent (NC) site. Both sites are adjacent to the Dolores River. The UC site is approximately 1 mile (mi) (2 kilometers [km]) downstream of the NC site. Contaminated materials cover an estimated 55 acres (ac) (22 hectares [ha]) at the UC site and 12 ac $(4.9 \mathrm{ha})$ at the NC site. The sites contain former mill building concrete foundations, tailings piles, demolition debris, and areas contaminated by windblown and waterborne radioactive materials. The total estimated volume of contaminated materials is approximately 621,000 cubic yards $(475,000$ cubic meters). In addition to the contamination at the two processing site areas, 13 vicinity properties were contaminated. Contamination associated with the UC and NC sites has leached into ground water.

\section{REMEDIAL ACTION}

Pursuant to the requirements of the Uranium Mill Tailings Radiation Control Act (UMTRCA) (42 USC $\$ 7901$ et seq.), the proposed remedial action plan (RAP) will satisfy the final U.S. Environmental Protection Agency (EPA) standards in 40 CFR Part 192 (60 FR 2854) for cleanup, stabilization, and control of the residual radioactive material (RRM) (tailings and other contaminated materials) at the disposal site at Burro Canyon. The requirements for control of the RRM (Subpart A) will be satisfied by the construction of an engineered disposal cell.

The proposed remedial action will consist of relocating the uranium mill tailings, contaminated vicinity property materials, demolition debris, and windblown/waterborne materials to a permanent repository at the Burro Canyon disposal site. The site is approximately 5 road $\mathrm{mi}(8 \mathrm{~km})$ northeast of the mill sites on land. recently transferred to the DOE by the Bureau of Land Management. The disposal site location was based on public input, environmental considerations, and regulatorily acceptable design opportunities.

The disposal cell will be partially below grade. Excavation for the cell will penetrate through the Dakota Sandstone and into the low-permeability claystones and mudstones of the underlying Burro Canyon Formation, where the contaminated material will be placed into the base of the cell. The excavation will be approximately 30 feet (ft) ( 9 meters [m]) deep at the shallow end of the disposal cell and approximately 45 to $50 \mathrm{ft}$ (14 to $15 \mathrm{~m}$ ) at the deep end of the cell. Most of the Dakota Sandstone and the mudstone/claystone of the Burro Canyon Formation are considered rippable by large bulldozers, but some limited blasting may be required. An on-site geologist will monitor and evaluate the disposal cell excavation to limit the amount of blasting. The mudstone/claystone of the Burro Canyon Formation will provide a natural impermeable barrier from the base of the disposal cell ranging from 7 to $39 \mathrm{ft}(2$ to $12 \mathrm{~m})$ up the side wall to form a continuous, saucer-shaped bottom and side liner. The RRM will be covered with a 4-ft 8-inch $(1.4-\mathrm{m})$ cover on the 
topslopes and a $5-\mathrm{ft}(1.5-\mathrm{m})$ cover on the sideslopes. Both the topslope and sideslope covers will include a radon/infiltration barrier, layers to protect the barrier against frost penetration and moisture buildup, a sand and gravel bedding/drainage layer, and a rock erosion-protection layer at the surface of the cell.

\section{DESIGN ANALYSES}

This proposed RAP incorporates the results of detailed investigation of geologic, geomorphic, and seismic conditions at the disposal site. The disposal site will be geomorphically stable (i.e., against gully erosion in the cell vicinity or slope failure). Seismic design parameters were developed for the geotechnical analyses of the disposal cell. Cell stability was analyzed to ensure long-term performance in meeting design standards, including slope stability, settlement, and liquefaction potential.

The proposed cell cover and erosion protection features also were analyzed and designed to protect the RRM against surface water and wind erosion. The location of the cell precludes the need for permanent drainage or interceptor ditches. Rock to be used on the cell top-, side-, and toeslopes was sized to withstand probable maximum precipitation events.

The requirements for radon emissions of 40 CFR Part 192, Subpart A, will be met with the disposal cell's $1.5-\mathrm{ft}(0.45-\mathrm{m})$-thick, fine-grained radon barrier.

\section{GROUND WATER COMPLIANCE}

To achieve compliance with the final EPA ground water protection standards (60 FR 2854), the U.S. Department of Energy (DOE) proposes a supplemental standard that will ensure protection of human health and the environment. This standard applies to the ground water in the uppermost aquifer, defined as the low-yield ground water in the upper sandstone unit of the Burro Canyon Formation. The disposal cell foundation will be separated from the uppermost aquifer by a thick layer (50 to $65 \mathrm{ft}$ [15 to $20 \mathrm{~m}$ ) of lowpermeability mudstone. Ground water in the underlying lithologic units is protected from potential site-related contamination by low-permeability mudstone/claystone units and upward vertical hydraulic gradients that inhibit downward migration of water. This supplemental standard will be narrative and will not include numerical concentration limits for hazardous constituents identified in the RRM at the Slick Rock sites. In addition, point of compliance monitoring is not proposed. Ground water monitoring would not be effective at the Burro Canyon disposal site and is therefore not proposed because insufficient yield in the uppermost aquifer precludes its future use. The only point of exposure that could potentially affect human health or the environment would be surface seepage at the base of the disposal cell mesa. During remedial action construction, stand pipes will be installed in the bottom of the disposal cell to drain any accumulating water via sump pumps. In lieu of ground water monitoring, the DOE will conduct compliance monitoring through visual inspections to locate surface expressions of seepage at and in the vicinity of the Burro Canyon disposal site. These visual inspections will include looking for physical evidence of mineralization, phreatophyte vegetation, and saturated zones at sandstone outcrops. The lateral movement of tailings pore fluids will be monitored through the installation of a minimum of one piezometer in the $\mathrm{Kd} 1$ and $\mathrm{Kd} 2$ sandstones of 
SLICK ROCK REMEDIAL

the Dakota Sandstone at the toe of the cell. Details will be provided in the long-term surveillance and maintenance plan. 
1.0 INTRODUCTION . . . . . . . . . . . . .

1.1 EPA standards $\ldots \ldots \ldots \ldots \ldots \ldots \ldots \ldots \ldots \ldots \ldots \ldots \ldots \ldots \ldots \ldots \ldots, 1-2$

1.2 Site and proposed action $\ldots \ldots \ldots \ldots \ldots \ldots \ldots \ldots \ldots \ldots, 1-2$

1.2.1 History ......................... 1-2

1.2.2 Location ......................... 1-2

1.2.3 Contaminated materials $\ldots \ldots \ldots \ldots \ldots \ldots \ldots \ldots \ldots, 1-4$

1.2.4 Remedial action...................... 1-4

1.3 Scope and content ......................... 1-10

1.4 Remedial action selection organization $\ldots \ldots \ldots \ldots \ldots \ldots \ldots \ldots \ldots$ 1-10

1.5 Collateral documents $\ldots \ldots \ldots \ldots \ldots \ldots \ldots \ldots \ldots \ldots \ldots \ldots \ldots$

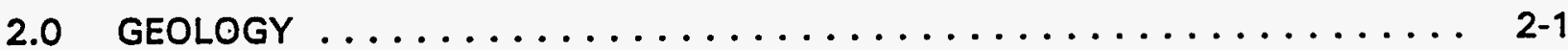

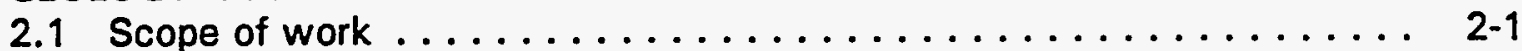

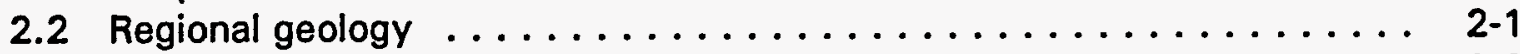

2.2.1 Regional physiography $\ldots \ldots \ldots \ldots \ldots \ldots \ldots \ldots \ldots \ldots, 2-2$

2.2.2 Stratigraphic setting $\ldots \ldots \ldots \ldots \ldots \ldots \ldots \ldots \ldots \ldots, 2-2$

2.2.3 Structural setting $\ldots \ldots \ldots \ldots \ldots \ldots \ldots \ldots \ldots \ldots \ldots, 2-2$

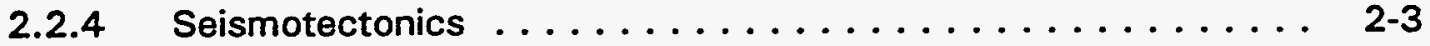

2.2.5 Resource development .................. 2-4

2.3 Site geology .......................... $2-5$

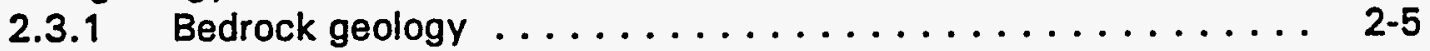

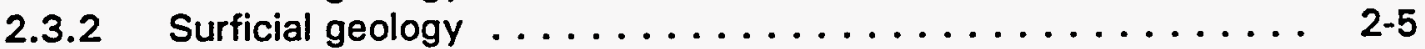

2.3.3 Geomorphology .................... $2-5$

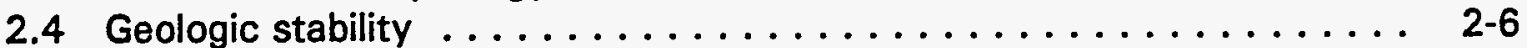

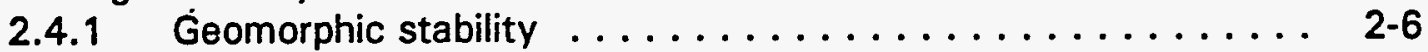

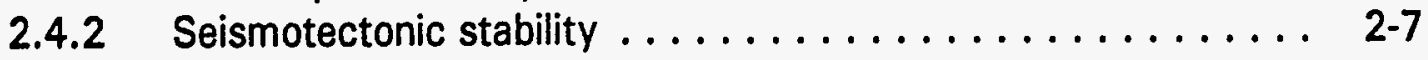

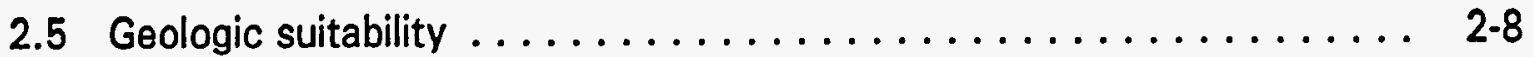

3.0 GEOTECHNICAL ENGINEERING $\ldots \ldots \ldots \ldots \ldots \ldots \ldots \ldots \ldots \ldots \ldots \ldots \ldots \ldots$

3.1 Introduction ............................

3.2 Site and material characterization ................. 3-1

3.2.1 Geotechnical investigation $\ldots \ldots \ldots \ldots \ldots \ldots \ldots \ldots$ 3-1

3.2.2 Testing program $\ldots \ldots \ldots \ldots \ldots \ldots \ldots \ldots \ldots \ldots \ldots \ldots . \ldots \ldots$

3.2.3 Ground water conditions $\ldots \ldots \ldots \ldots \ldots \ldots \ldots \ldots \ldots . \ldots \ldots$

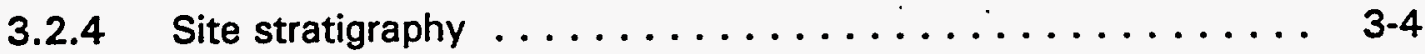

3.3 Geotechnical engineering evaluation $\ldots \ldots \ldots \ldots \ldots \ldots \ldots \ldots$ 3-5

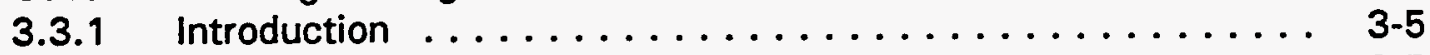

3.3.2 Slope stability $\ldots \ldots \ldots \ldots \ldots \ldots \ldots \ldots \ldots \ldots \ldots, 3-5$

3.3.3 Settlement ....................... 3-6

3.3.4 Liquefaction potential . . . . . . . . . . . . . . . .

3.3.5 Cover design ........................ 3-7

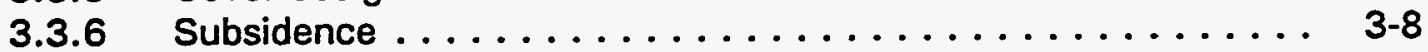

3.4 Construction details $\ldots \ldots \ldots \ldots \ldots \ldots \ldots \ldots \ldots \ldots \ldots \ldots . .3 .8$

3.4.1 Construction methods and features $\ldots \ldots \ldots \ldots \ldots \ldots .3 .8$ 


\section{TABLE OF CONTENTS (Continued)}

Section

3.4.2 Testing and inspection $\ldots \ldots \ldots \ldots \ldots \ldots \ldots \ldots . .3-9$

3.4.3 Construction activities and construction sequence $\ldots \ldots \ldots 3-10$

3.5 Summary ........................... 3 .13

4.0 SURFACE WATER HYDROLOGY AND EROSION PROTECTION . . . . . . . . 4-1

4.1 Hydrologic description and remedial action design ........... 4-1

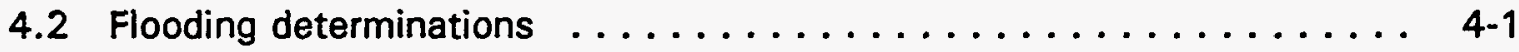

4.2.1 Probable maximum precipitation .............. 4-1

4.2.2 Infiltration losses ..................... 4-1

4.2.3 Time of concentration .................. 4-3

4.2.4 Rainfall distributions - probable maximum precipitation ..... 4-3

4.2.5 Computation of probable maximum flood ........... 4-3

4.3 Flow depth and velocities . . . . . . . . . . . . . . . 4-3

4.3.1 Adjacent waterways ................... 4-3

4.3.2 Drainage ditches ...................... 4-4

4.3.3 Top and sides of the embankment ............... 4 4-4

4.4 Erosion protection ......................... 4.4

4.4.1 Topslopes ........................ 4.4

4.4 .2 Sideslopes $\ldots \ldots \ldots \ldots \ldots \ldots \ldots \ldots \ldots \ldots \ldots \ldots \ldots$ 4.4

4.4.3 Toe and sides of the embankment . . . . . . . . . . . . . 4-5

4.5 Rock durability . . . . . . . . . . . . . . . . . . . . . 4-5

4.6 Quality control testing and inspection for erosion protection . . . . . . 4-5

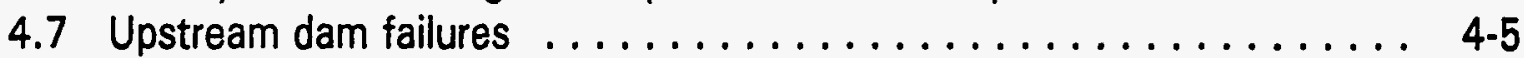

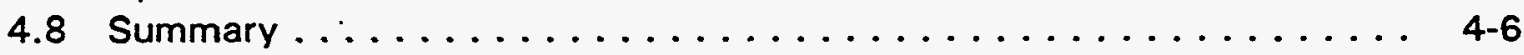

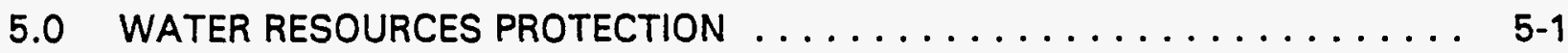

5.1 Hydrogeologic characterization ................... $5-1$

5.1 .1 Identification of hydrogeologic units $\ldots \ldots \ldots \ldots \ldots \ldots \ldots$ 5-1

5.1.2 Hydraulic and transport properties . . . . . . . . . . . 5-8

5.1 .3 Geochemical conditions ................... 5-10

5.1 .4 Characterization methods .................. 5-12

5.1 .5 Water use ......................... 5-16

5.2 Conceptual design features for water resources protection . . . . . 5-17

5.3 Disposal ............................. 5-18

5.3.1 Ground water protection standard for disposal ......... 5-19

5.3.2 Narrative supplemental standard ... . . . . . . . . . . . 5-22

5.3.3 Point of exposure ...................... 5-24

5.4 Performance assessment and demonstration . . . . . . . . . . . 5-28

5.5 Ground water monitoring . . . . . . . . . . . . . . . . 5-29

5.6 Ground water cleanup . . . . . . . . . . . . . . . . . . . 5-29

5.6.1 Ground water cleanup standard . . . . . . . . . . . . 5-29

5.6 .2 Cleanup demonstration $\ldots \ldots \ldots \ldots \ldots \ldots \ldots \ldots \ldots \ldots$ 5-30

5.6 .3 Cleanup monitoring program ................. 5-30 
TABLE OF CONTENTS (Concluded)

Section

Page

5.7 Water resources protection strategy summary . . . . . . . . . 5-30

6.0 RADON ATTENUATION AND SITE CLEANUP $\ldots \ldots \ldots \ldots \ldots \ldots \ldots \ldots$

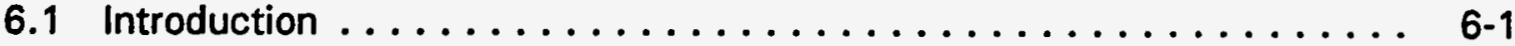

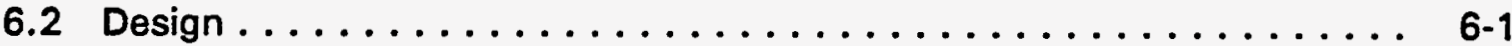

6.3 Radon barrier parameters $\ldots \ldots \ldots \ldots \ldots \ldots \ldots \ldots \ldots \ldots \ldots \ldots . \ldots \ldots$

6.3.1 Long-term moisture . . . . . . . . . . . . . . . . . . . 6-2

6.3 .2 Radon diffusion ......................... $6-2$

6.3.3 Radon emanation .......................... 6-3

6.3.4 Dry densities and porosities ................. 6-3

6.3.5 Layer thickness ........................... 6.4

6.3.6 Radium-226 concentrations ................. 6.4

6.3.7 Ambient radon concentration ................... $6-4$

6.4 Evaluation of radon barrier . . . . . . . . . . . . . . . . 6-4

6.5 Site cleanup .............................. 6.5

6.5.1 Radiological site characterization ............... 6-5

6.5 .2 Standards for cleanup ................... 6-7

6.5.3 Verification of cleanup ................... 6-8

6.6 Summary and conclusion . . . . . . . . . . . . . . . . . 6-8

7.0 LIST OF CONTRIBUTORS $\ldots \ldots \ldots \ldots \ldots \ldots \ldots \ldots \ldots \ldots \ldots \ldots$

8.0 REFERENCES $\ldots \ldots \ldots \ldots \ldots \ldots \ldots \ldots \ldots \ldots \ldots \ldots \ldots \ldots \ldots \ldots \ldots$

ATTACHMENT 1 SPECIFICATIONS, DESIGN DRAWINGS, INFORMATION FOR REVIEWERS, INFORMATION FOR BIDDERS, CALCULATIONS AND REPORTS, COST ESTIMATES

ATTACHMENT 2 GEOLOGY REPORT

ATTACHMENT 3 GROUND WATER HYDROLOGY REPORT

ATTACHMENT 4 WATER RESOURCES PROTECTION STRATEGY 


\section{LIST OF FIGURES}

\section{Figure}

Page

1.1 Locations of the North Continent and Union Carbide

sites near Slick Rock, Colorado . . . . . . . . . . . . . . . . . . . . 1-3

1.2 Union Carbide and North Continent sites near Slick Rock, Colorado . . . . . . 1-5

1.3 Locations of Burro Canyon disposal site and processing sites near Slick Rock, Colorado . . . . . . . . . . . . . . 1-7

1.4 Disposal cell near Slick Rock, Colorado . . . . . . . . . . . . . . . . . . 1-8

1.5 Cross section of disposal cell, Burro Canyon disposal site near Slick Rock, Colorado ........................... 1-9

3.1 Remedial action schedule, Slick Rock, Colorado, sites . . . . . . . . . . 3-14

4.1 Drainage systems, Burro Canyon disposal site area near Slick Rock, Colorado . . . . . . . . . . . . . . . . . . . 4-2

5.1 Ground water and surface water sampling locations near Slick Rock, Colorado ... . . . . . . . . . . . . . . . . . . . . . 5-2

5.2 Geologic cross section (northwest-southeast), NC and UC sites near Slick Rock, Colorado . . . . . . . . . . . . . . . . . . . . . . . . . . 5-3

5.3 Monitor well locations, Burro Canyon disposal site near Slick Rock, Colorado . . . . . . . . . . . . . . . . . . . 5-6

5.4 Geologic cross section (northwest-southeast), Burro Canyon disposal site near Slick Rock, Colorado . . . . . . . . . . . . . . 5 5-7

5.5 Structural map of upper sandstone unit, Burro Canyon Formation near Slick Rock, Colorado . . . . . . . . . . . . . . 5-25

5.6 Representative diagrammatic section of strata, Burro Canyon Formation near Slick Rock, Colorado . . . . . . . . . . . . 5-26

6.1 Areal extent of Ra-226 soil concentrations exceeding $5 \mathrm{pCi} / \mathrm{g}$ at the NC and UC tailings sites near Slick Rock, Colorado . . . . . . . . . . . 6-6 


\section{LIST OF TABLES}

Table

Page

1.1 Contaminated material volumes at the Slick Rock, Colorado, processing sites ........................... 1-6

1.2 Relationship between design details, criteria, and supporting calculations, Slick Rock, Colorado, site . . . . . . . . . . . . . 1-11

3.1 Results of slope stability analysis, Slick Rock, Colorado, site . . . . . . . . 3-16

3.2 Cover components and their functions $\ldots \ldots \ldots \ldots \ldots \ldots \ldots$

4.1 Rock size requirements and layer thicknesses for the Burro Canyon, Colorado, disposal cell .................... 4 4-5

5.1 Average hydraulic properties at the Slick Rock, Colorado, processing sites ............................. 5-8

5.2 Average hydraulic properties at the Slick Rock, Colorado, disposal site . . . . . . . . . . . . . . . . . . . . . . . . . 5 5-9

5.3 Summary of hazardous constituents identified at the Slick Rock, Colorado, processing sites . . . . . . . . . . . . . . . . . . . 5-21

6.1 Background radioactivity and radiological conditions at the Slick Rock, Colorado, sites 


\section{LIST OF ACRONYMS}

\section{Acronym}

ALARA

ASTM

DOE

EPA

FE

$M C L$

ME

MSL

NC

NRC

ORNL

PHA

PMP

POC

$Q A$

QC

RAC

RAP

RAS

RRM

SF\&C

SPEAR

SRP

$T_{C}$

TAC

TAD

TDS

TER

UC

UMTRA

UMTRCA

\section{Definition}

as low as reasonably achievable

American Society for Testing and Materials

U.S. Department of Energy

U.S. Environmental Protection Agency

floating earthquake

maximum concentration limit

maximum earthquake

mean sea level

North Continent

U.S. Nuclear Regulatory Commission

Oak. Ridge National Laboratory

peak horizontal acceleration

probable maximum precipitation

point of compliance

quality assurance

quality control

Remedial Action Contractor

remedial action plan

remedial action selection

residual radioactive material

standard format and content

Software Program for Environmental Analysis and Reporting

standard review plan

time of concentration

Technical Assistance Contractor

Technical Approach Document

total dissolved solids

technical evaluation report

Union Carbide

Uranium Mill Tailings Remedial Action

Uranium Mill Tailings Radiation Control Act 


\subsection{INTRODUCTION}

The inactive uranium mill tailings sites near Slick Rock, Colorado, were designated as 2 of 24 abandoned uranium tailings sites to be remediated by the U.S. Department of Energy (DOE) under the Uranium Mill Tailings Radiation Control Act (UMTRCA) of 1978 (42 USC $\$ 7901$ et seq.). The UMTRCA requires that the U.S. Nuclear Regulatory Commission (NRC) concur with the DOE's remedial action plan (RAP) and certify that the remedial action complies with the standards promulgated by the U.S. Environmental Protection Agency (EPA). The RAP, which includes this remedial action selection (RAS) report, serves two purposes. First, it describes the activities proposed by the DOE to accomplish long-term stabilization and control of residual radioactive material (RRM) at the inactive uranium processing sites near Slick Rock, Colorado. Second, this document and the remainder of the RAP, upon concurrence and execution by the DOE, the state of Colorado, and the NRC, will become Appendix B of the cooperative agreement between the DOE and the state of Colorado.

The DOE objective in preparing this RAP is to comply with EPA regulations in Subparts $A$ through $C$ of 40 CFR Part 192. All remedial action planning and design considerations contained herein reflect the incorporation of this regulatory guidance. Therefore, by performing all remedial action activities in accordance with the design presented in this RAP, the DOE will meet the standards of 40 CFR Part 192. Section 1.1 summarizes these regulations.

\section{$1.1 \quad$ EPA STANDARDS}

As required by Title I of the UMTRCA, remedial action at the Slick Rock sites must comply with regulations established by the EPA in 40 CFR Part 192, Subparts $A$ through $C$. The regulations are summarized below:

- The disposal site shall be designed to stabilize and control the tailings and other RRM for 1000 years to the extent reasonably achievable and, in any case, for at least 200 years (40 CFR \$192.02(b)).

- The disposal site design shall prevent radon-222 flux from RRM into the atmosphere from exceeding 20 picocuries per square meter per second $\left(\mathrm{pCi} / \mathrm{m}^{2} \mathrm{~s}\right)$, or from increasing the annual average concentration of radon-222 in air by more than 0.5 picocurie per liter (pCi/L) (40 CFR $\$ 192.02(b)$ ).

- The remedial action shall be conducted to provide reasonable assurance that as a result of any RRM at any designated processing site the concentration of radium-226 in land, averaged over 100 square meters $\left(\mathrm{m}^{2}\right)$, does not exceed the background level by more than 5 picocuries per gram (pCi/g), averaged over the first 15 centimeters $(\mathrm{cm})$ of soil below the surface and $15 \mathrm{pCi} / \mathrm{g}$ averaged over $15-\mathrm{cm}$-thick layers of soil more than $15 \mathrm{~cm}$ below the surface (40 CFR §192.12(a)). 
In September 1985, the U.S. Court of Appeals for the Tenth Circuit remanded the ground water standards contained in 40 CFR \$192.2(a)(2)-(3). The court stipulated that the EPA promulgate new ground water standards of a general nature applicable to all Title I uranium mill sites.

In September 1987, the EPA issued proposed standards in response to the court remand. The final standards were issued in January 1995 (60 FR 2854). These standards apply to disposal of the tailings (Subpart A), cleanup of ground water contaminated by the former mills (Subpart B), and implementation of the remedial action (Subpart $\mathrm{C}$ ).

\subsection{SITE AND PROPOSED ACTION}

\subsubsection{History}

The first uranium concentrating plant in the world was constructed near the UC site in 1898 by the French chemical scientists, Ponilot and Voiligne. The plant operated for only a few years before it was abandoned. While no tailings or structures remain from this old operation, some radiological contamination is associated with this former mill site.

The Slick Rock tailings sites consist of two tailings piles: one each at the Union Carbide (UC) site and the North Continent (NC) site. Umetco, a subsidiary of the Union Carbide Corporation, now owns both sites. The UC mill began operating in 1957, and processed ore mined from the surrounding area. Upgraded material from the UC site was trucked to the mill in Rifle, Colorado. The NC mill site dates to 1931, when it was owned by Shattuck Chemical Company. The federal government acquired control of the site through the Union Mines Development Corporation with the specific purpose of supplying uranium and vanadium for the Manhattan Project. Umetco became the owner of the site in 1957. Except for some concrete foundations, all the mill buildings have been removed from the UC site. The former recreational building and dormitory remain adjacent to the site. Mobile homes have been removed from a trailer park area off the site, leaving concrete pads. All structures (including foundations) have been removed from the NC site. Both tailings piles were covered with soil and are at least partially vegetated.

\subsubsection{Location}

Both the UC and NC tailings sites are in San Miguel County, Colorado (Figure 1.1). The tailings sites are adjacent to the Dolores River and are surrounded by steep, juniper-covered hillsides and cliffs of the Dolores River Canyon. The tailings sites are 5500 feet $(\mathrm{ft})(1700$ meters [m]) above mean sea level (MSL), while the surrounding hillsides reach $6500 \mathrm{ft}(2000 \mathrm{~m})$ above MSL. The UC tailings site is approximately 1 mile (mi) (2 kilometers [km]) downstream of the NC tailings site. 


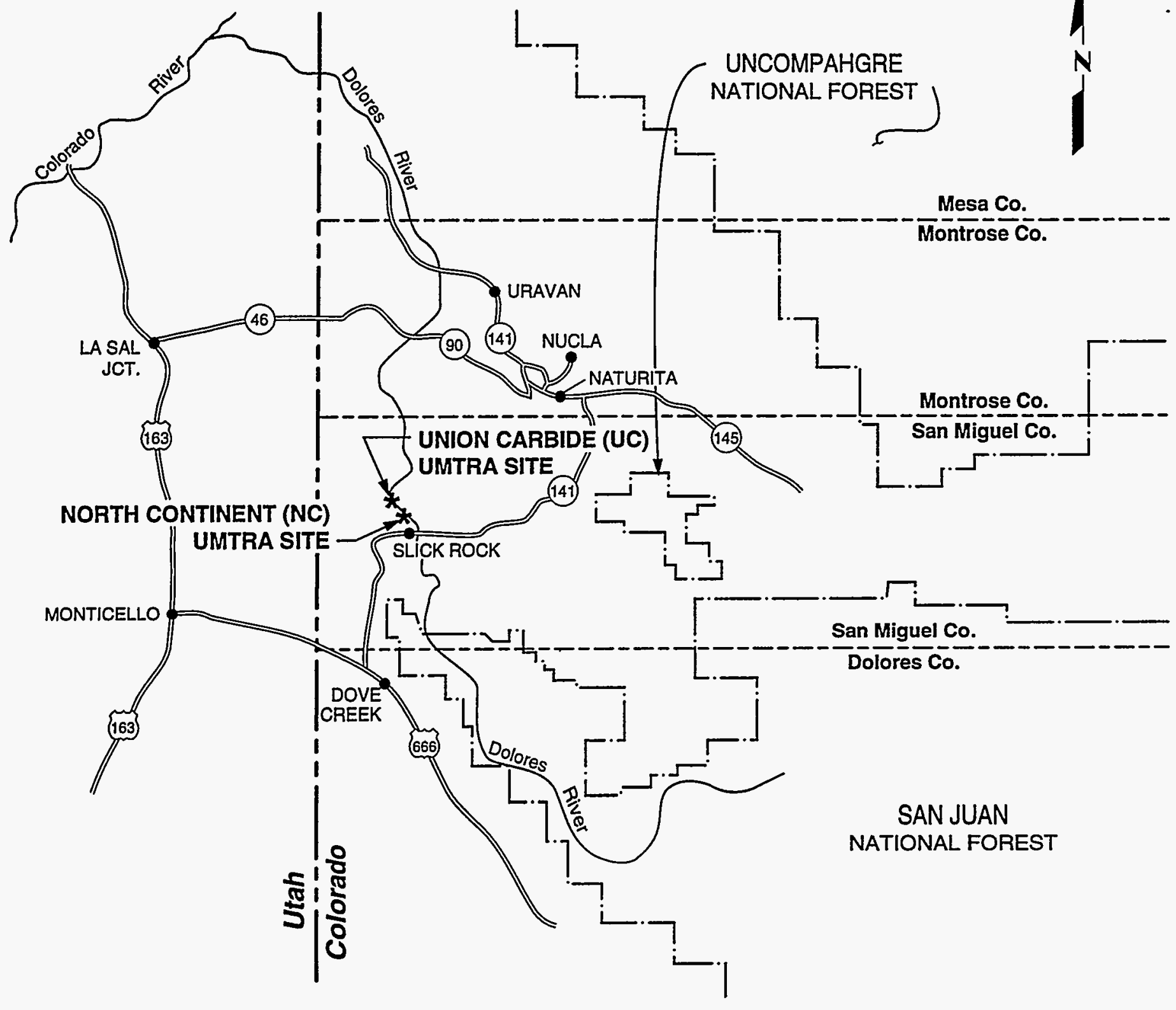

LEGEND
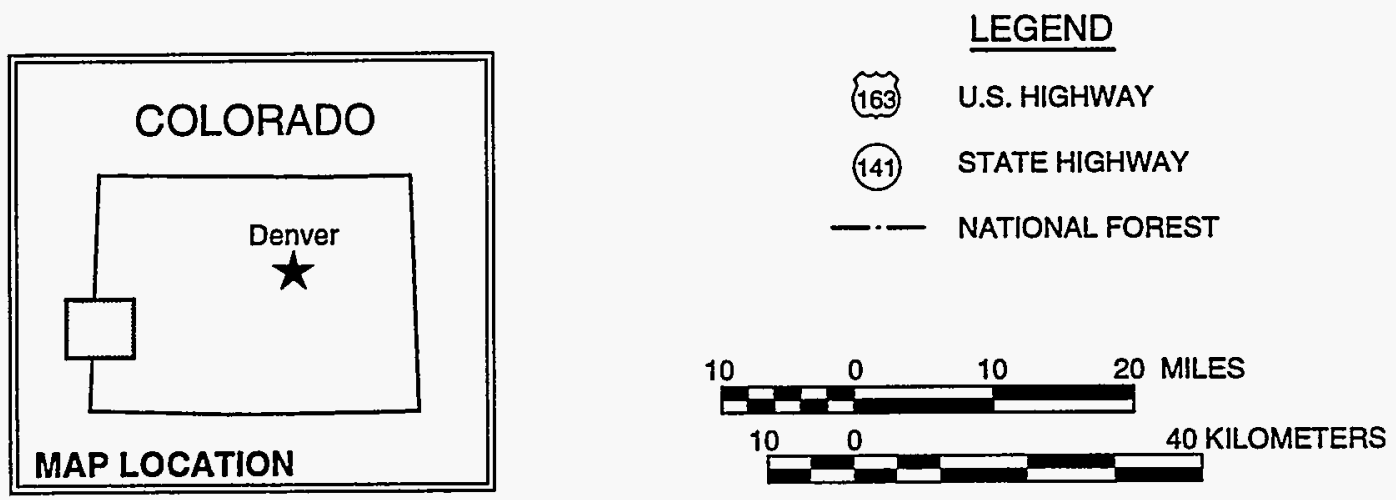

FIGURE 1.1

LOCATIONS OF THE NORTH CONTINENT AND UNION CARBIDE SITES NEAR SLICK ROCK, COLORADO 
The sites are arid with a mean annual precipitation of 9 inches $(200$ millimeters [mm]). The dominant land use in the area is grazing. A gas sweetener plant is adjacent to the UC tailings pile. As mining was common in the area in the past, there are now numerous abandoned mines and mining roads. The area is sparsely populated; six people live within $1.6 \mathrm{mi}(2.6 \mathrm{~km})$ of the site.

\subsubsection{Contaminated materials}

The UC tailings site consists of the tailings pile, former mill site, and windblown/ waterborne contaminated areas (Figure 1.2). The tailings pile and the surrounding contaminated land cover 55 acres (ac) (22 hectares [ha]). Approximately 536,000 cubic yards $\left(y d^{3}\right)\left(410,000\right.$ cubic meters $\left.\left[\mathrm{m}^{3}\right]\right)$ of contaminated material at the UC site are distributed as shown in Table 1.1.

The NC tailings site consists of the tailings pile and windblown contaminated areas (Figure 1.2). The tailings pile is difficult to differentiate from the surrounding contaminated land. Approximately 12 ac (4.9 ha) are contaminated, with approximately $85,000 \mathrm{yd}^{3}\left(65,000 \mathrm{~m}^{3}\right)$ of contaminated materials distributed as shown in Table 1.1.

\subsubsection{Remedial action}

The proposed remedial action consists of removing all tailings-contaminated material from both former mill sites to the Burro Canyon disposal site approximately $2.5 \mathrm{mi}(4.0 \mathrm{~km})$ east of the UC and NC processing sites in Sections 21 and 28, Township 44 North, Range 18 West (Figure 1.3). Contaminated materials will be transported over an approximately $6-\mathrm{mi}(10-\mathrm{km})$ haul route. The approximately $1-\mathrm{mi}(2-\mathrm{km})$ access road from Colorado State Highway 141 to the Burro Canyon disposal site will require upgrading, as will the access road between the NC site and Highway 141. The remainder of the haul route is on state- and county-maintained roads.

Figures 1.4 and 1.5 present the disposal cell. Disposal will consist of constructing a 12-ac (4.9-ha) engineered cell partially below grade. The location of the disposal cell will optimize the saddle and mesa topography at the Burro Canyon site. The cell will be shaped to avoid or minimize detrimental effects of surface water drainage and potential geomorphic change.

To this end, the edge of the tailings and contaminated materials in the disposal cell will be no closer than $100 \mathrm{ft}(30 \mathrm{~m})$ to the edge of the mesa.

The disposal cell will hold approximately $621,000 \mathrm{yd}^{3}\left(475,000 \mathrm{~m}^{3}\right)$ of contaminated material and cover an area approximately $610 \mathrm{ft}(190 \mathrm{~m})$ wide and $900 \mathrm{ft}(280 \mathrm{~m})$ long. The height of the cell will range from $30 \mathrm{ft}(9 \mathrm{~m})$ to $50 \mathrm{ft}(15 \mathrm{~m})$ above the existing ground surface. The disposal cell footprint will be excavated to prepare for emplacement of the contaminated materials. Some of the excavated materials will be used as fill along the embankment sides and 
Table 1.1 Contaminated material volumes at the Slick Rock, Colorado, processing sites

\begin{tabular}{lrr}
\hline & \multicolumn{2}{c}{ Volume } \\
\cline { 3 - 3 } & \multicolumn{1}{c}{$\left(\mathrm{yd}^{3}\right)$} & \multicolumn{1}{c}{$\left(\mathrm{m}^{3}\right)$} \\
\hline UC site & & \\
Tailings & 296,000 & 226,000 \\
Contaminated materials & 237,500 & 181,600 \\
Demolition debris & 2,850 & 2,180 \\
Subtotal & 536,350 & 409,780 \\
NC site & & \\
Contaminated soil/tailings & 84,800 & 64,800 \\
$\quad$ Subtotal & 84,955 & 64,919 \\
\hline Totals (rounded) & 621,300 & 474,700 \\
\hline
\end{tabular}

for the upper portion of the cover. Most, if not all, of the remaining excavated material will be used for the radon barrier.

All contaminated materials will be covered with a $1.5-\mathrm{ft}(0.45-\mathrm{m})$-thick layer of fine-grained materials that will constitute a radon barrier to prevent release of radon into the atmosphere. A 2-ft $(0.6-\mathrm{m})$-thick frost-protection layer of fine-grained material will be placed over the radon barrier, and then a 6 -inch $(150-\mathrm{mm})$ sand and gravel bedding layer. The top of the cover will consist of riprap ranging in depth from 8 to 12 inches $(200$ to $300 \mathrm{~mm})$. The disposal cell will have a 2- to 4-percent topslope and 25-percent sideslopes. The completed disposal cell will occupy an area of 12 ac ( 4.9 ha). A buffer area of 32 ac (13 ha) will bring the total final disposal site area to 44 ac (18 ha).

The remedial action is expected to take 24 months. During the summer of the first year, the sites will be prepared, the existing dirt road upgraded, the disposal cell excavated, existing foundations demolished, and contaminated materials from the UC and NC sites excavated and placed. A 3- to 5-month winter shutdown will be scheduled. The second-summer activities will include collecting cover materials from the Dolores River rock borrow site and constructing the cover system. Final site grading and site restoration will also be performed.

Detailed drawings of the disposal cell facility are shown in Attachment 1, Drawing Nos. SRK-0-10-0330 through SRK-DS-10-0338.

After the contaminated materials are removed, the processing sites will be restored with uncontaminated fill and revegetated or mulched. After remedial action, the processing site eventually will be released for use consistent with existing land use controls. 


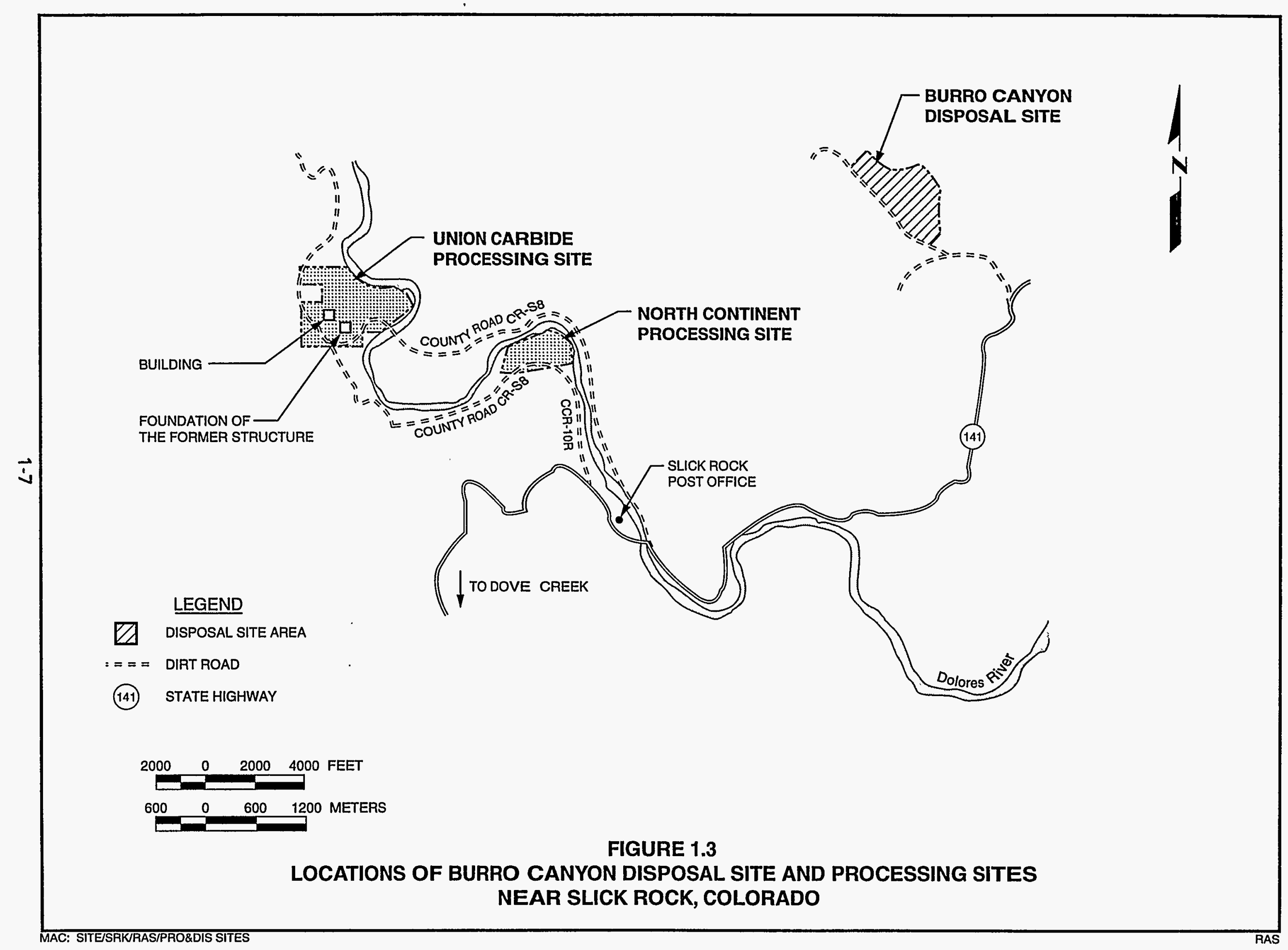




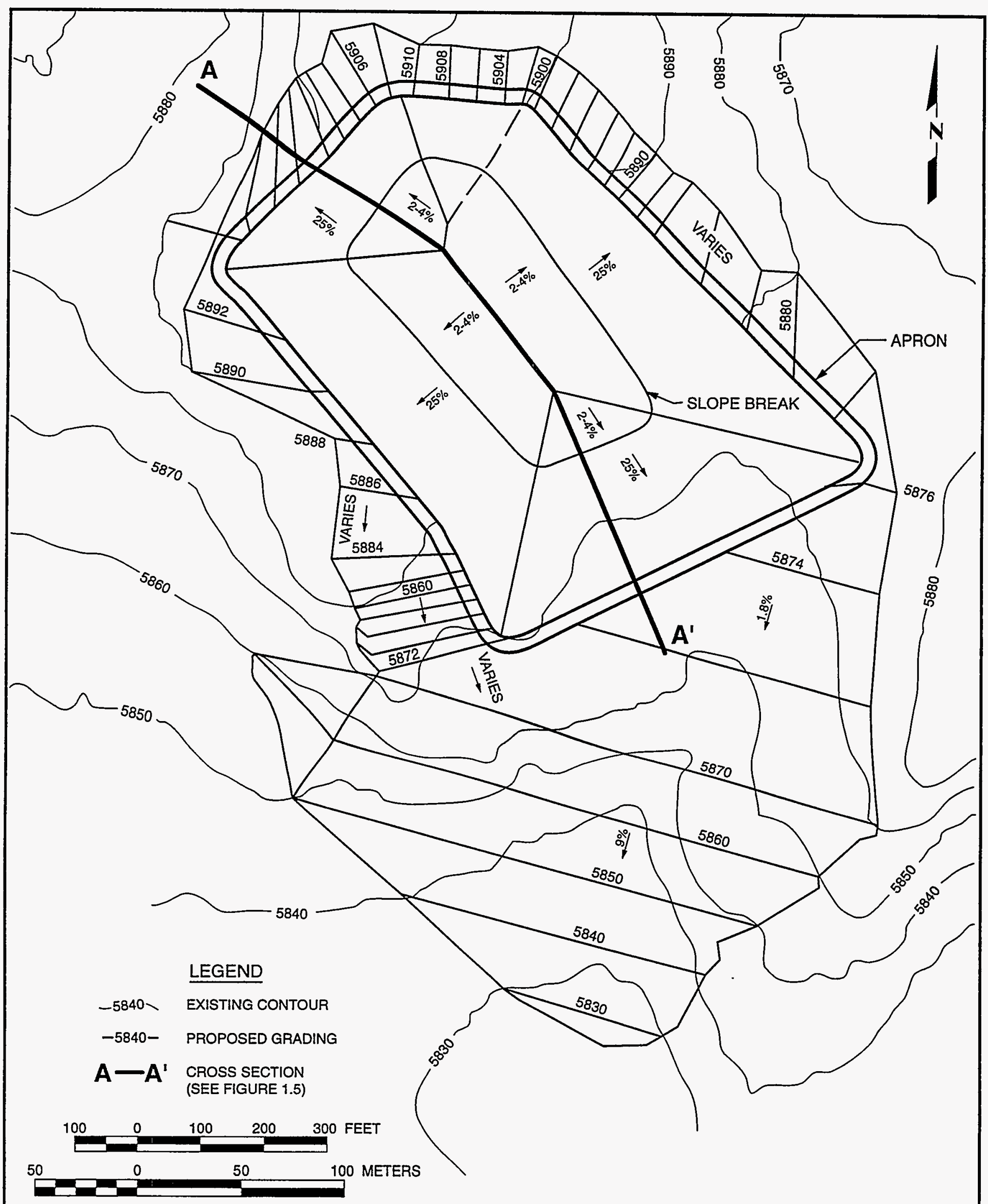

FIGURE 1.4

DISPOSAL CELL

NEAR SLICK ROCK, COLORADO 


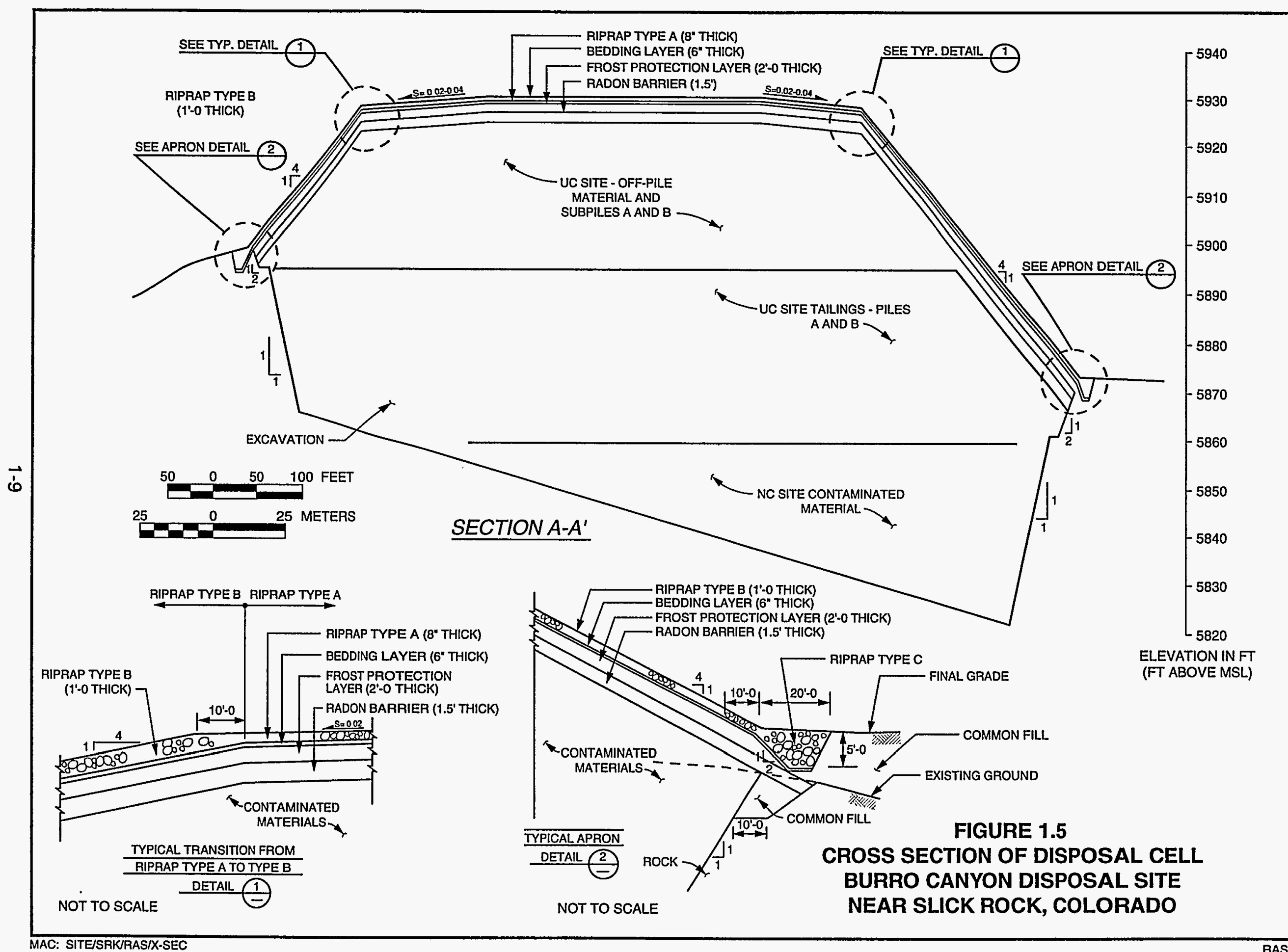


This RAS report has been structured to provide a brief but comprehensive description of the remedial action proposed for the Slick Rock sites. Data and supporting information generated for this remedial action are too extensive to be incorporated into this single document, although pertinent information and data are included, as are references to supporting documents. The RAP consists of this RAS and the following attached reports, which describe various aspects of the remedial action in more detail:

- Attachment 1. Specifications, Design Drawings, Information for Reviewers, Information for Bidders (four volumes), Calculations (four volumes), Reports (one volume), and Cost Estimates (one volume).

- Attachment 2, Geology Report.

- Attachment 3, Ground Water Hydrology Report.

- Attachment 4, Water Resources Protection Strategy.

1.4 REMEDIAL ACTION SELECTION ORGANIZATION

Sections 2.0 through 6.0 are organized by technical discipline. The approach adopted in the RAS report is similar to that adopted by the NRC for site technical evaluation reports (TER). This RAS report is formatted in accordance with the requirements of NRC standard format and content (SF\&C) guide (NRC, 1989) for remedial action selection for Uranium Mill Tailings Remedial Action (UMTRA) Project sites and has been compiled to facilitate NRC preparation of its TERs. The RAS report does not contain design details. These are available in supporting documents, reports, drawings, specifications, and calculations (see Attachment 1).

Table 1.2 summarizes the relationship between design details and criteria and supporting calculations and reports.

\subsection{COLLATERAL DOCUMENTS}

The environmental assessment of remedial action at the Slick Rock sites (DOE, 1994) describes existing conditions at the sites, the proposed remedial actions and alternatives, and the environmental impacts of the proposed remedial action. It also includes environmental details not reported in this RAP.

An additional supporting document is the Technical Approach Document (TAD) (DOE, 1989), which describes technical approaches and procedures used on the UMTRA Project. The TAD also discusses major technical areas, design considerations, surface water hydrology and erosion control, geotechnical aspects of pile design, radiological issues (the design of the radon barrier, in particular), and protection of ground water resources. 


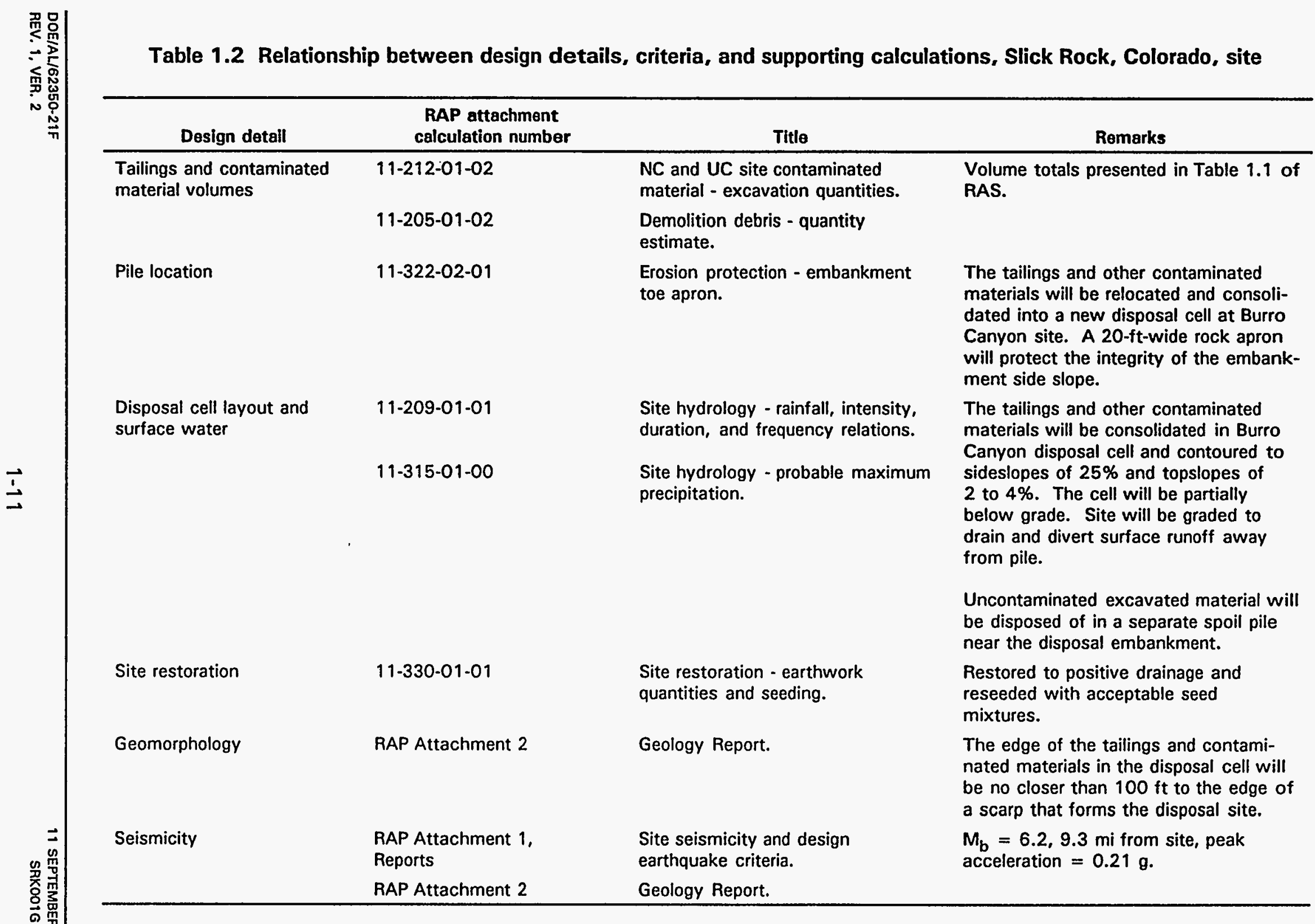


Table 1.2 Relationship between design details, criteria, and supporting calculations, Slick Rock, Colorado (Concluded)

\begin{tabular}{|c|c|c|c|}
\hline Design detail & $\begin{array}{c}\text { RAP attachment } \\
\text { calculation number }\end{array}$ & $\begin{array}{r}\text { Title } \\
\end{array}$ & $\begin{array}{l}\text { Remarks } \\
\end{array}$ \\
\hline \multirow[t]{4}{*}{ Erosion protection } & $11-322-01-00$ & $\begin{array}{l}\text { Erosion protection - embankment top- } \\
\text { and sideslopes. }\end{array}$ & $\begin{array}{l}\text { Riprap sizes and layer thickness were } \\
\text { determined. }\end{array}$ \\
\hline & $11-322-02-01$ & $\begin{array}{l}\text { Erosion protection - embankment toe } \\
\text { apron. }\end{array}$ & \\
\hline & $11-322-03-00$ & $\begin{array}{l}\text { Erosion protection - gradations and } \\
\text { layer thickness. }\end{array}$ & \\
\hline & $11-231-02-02$ & $\begin{array}{l}\text { Erosion protection - rock quality } \\
\text { evaluation. }\end{array}$ & \\
\hline \multirow[t]{3}{*}{ Radon/infiltration barrier } & $11-275-01-00$ & $\begin{array}{l}\text { Radon barrier design - statistical } \\
\text { analysis of radium- } 226 \\
\text { concentration data. }\end{array}$ & $\begin{array}{l}\text { Design thickness of } 1.5 \mathrm{ft}(0.45 \mathrm{~m} / \text { will } \\
\text { limit radon flux to meet EPA criteria. } \\
\text { Permeability will be less than } \\
10^{-7} \mathrm{~cm} / \mathrm{s} \text {. }\end{array}$ \\
\hline & $11-340-01-00$ & $\begin{array}{l}\text { Radon barrier design - RAECOM } \\
\text { input data. }\end{array}$ & \\
\hline & $11-340-02-01$ & $\begin{array}{l}\text { Radon barrier design - design } \\
\text { thickness. }\end{array}$ & \\
\hline \multirow[t]{5}{*}{ Geotechnical } & $11-250-04-03$ & $\begin{array}{l}\text { Embankment design - embankment } \\
\text { material properties. }\end{array}$ & $\begin{array}{l}\text { Properties used in stability and cover } \\
\text { cracking analysis. }\end{array}$ \\
\hline & $11-321-03-00$ & $\begin{array}{l}\text { Cover design - frost penetration } \\
\text { depth. }\end{array}$ & Frost penetration layer was provided. \\
\hline & $11-323-01-01$ & $\begin{array}{l}\text { Embankment design - settlement } \\
\text { and cover cracking analysis. }\end{array}$ & $\begin{array}{l}\text { There is no potential for cover cracking } \\
\text { due to differential settlement. }\end{array}$ \\
\hline & $11-310-02-00$ & $\begin{array}{l}\text { Embankment design - excavation } \\
\text { stability. }\end{array}$ & The excavation slopes are stable. \\
\hline & $11-310-01-00$ & $\begin{array}{l}\text { Embankment design - stability } \\
\text { analysis. }\end{array}$ & $\begin{array}{l}\text { The factor of safety exceeds minimum } \\
\text { requirement. }\end{array}$ \\
\hline \multirow[t]{2}{*}{ Ground water } & RAP Attachment 3 & Ground Water Hydrology Report. & \\
\hline & RAP Attachment 4 & $\begin{array}{l}\text { Water Resources Protection } \\
\text { Strategy. }\end{array}$ & Narrative supplemental standard. \\
\hline
\end{tabular}


Copies of these documents, as well as supporting data and calculations, are on file in the UMTRA Project Office, Albuquerque, New Mexico. 


\subsection{GEOLOGY}

This section documents that at the Burro Canyon disposal site, the DOE has adequately characterized the impact of geologic conditions on the long-term performance objectives of remedial action as defined by 40 CFR $\$ 192.02$.

The EPA standards listed in 40 CFR Part 192 do not include generic or site-specific requirements for characterization of the geological conditions at UMTRA Project sites. Rather, 40 CFR Part 192 requires that controls must be effective for 1000 years to the extent achievable, and in any case for at least 200 years. To achieve this long-term stability, certain geologic performance objectives must be met. For example, the NRC standard review plan (SRP) (NRC, 1985) requires information about basic regional and site geology and site stratigraphy. This information is the basis of the geotechnical and ground water aspects of disposal cell performance evaluation, described in Sections 3.0 and 5.0 of this document. An evaluation of the potential geomorphic hazards is required, and the DOE should show that potential geomorphic change will not affect the site or the disposal cell integrity throughout its design life. The site geological characterization should estimate earthquake-induced ground accelerations that could occur at the site, as well as the potential for other types of tectonic hazards that could affect the performance of the disposal cell. Geological site characterization also must demonstrate that future resource development will not adversely affect the disposal cell's stability during the design life. Additional criteria that support an evaluation of the adequacy of the site, regional geology, and the basis of the work described herein are in the TAD (DOE, 1989).

\subsection{SCOPE OF WORK}

The Technical Assistance Contractor (TAC) conducted detailed investigations of geologic, geomorphic, and seismic conditions at the site. Geologic investigations were carried out in accordance with the procedures and approaches described in the TAD (DOE, 1989) to gather the data specified in the NRC SRP and SF\&C guide. These investigations included the compilation and analysis of previously published and unpublished geological literature and data; review and analysis of historical and instrumental seismic data; geological field mapping and observations; review of site-specific subsurface geological and geotechnical data, including borehole logs and samples from boreholes, test pits, and trenches; aerial reconnaissance and analysis of stereo-pair aerial photographs; geologic interpretation of existing land satellite (LANDSAT) imagery; and studies of previous work. Details of data gathering and interpretation procedures are provided in the documents referenced in this section.

\subsection{REGIONAL GEOLOGY}

As noted in the NRC SRP, regional geology must be defined in sufficient detail to provide a clear perspective and orientation to site-specific subsurface information. 
The DOE has characterized the regional geologic conditions in the site geology report (Attachment 2). Information in this RAS report was derived from published studies referenced in Attachment 2 . The site region is defined as the area within a $40-\mathrm{mi}(65-\mathrm{km})$ radius of the disposal site.

\subsubsection{Regional physiography}

As required in the NRC SF\&C guide, the following main physiographic features of the region will be characterized:

- Type of geomorphic surface that surrounds the site.

- General relief and topography of the region.

- Regional drainage systems.

- Major regional geomorphic processes.

The Burro Canyon site is in the northeastern part of the Colorado Plateau physiographic province near its boundary with the southern Rocky Mountain province. This portion of the Colorado Plateau is characterized by large-scale folds, unwarped plateaus, and deep, narrow river canyons. The entrenched meanders of the Dolores River and the folded belt of the Paradox Basin are the principal features of the region.

Further details of the regional physiographic setting and the basis for the above description are contained in Section 2.1 of Attachment 2. That section describes the geomorphic landforms, relief and topography of the region, drainage systems, and types and rates of the major geomorphic processes.

\subsubsection{Stratigraphic setting}

Bedrock in the site region includes exposures of complete stratigraphic sequences of Mesozoic deposits. Most upper Cretaceous and all Tertiary deposits have been removed by erosion. Paleozoic rocks underlie the region but are rarely exposed.

Further details of the technical approach to and the results of the characterization of the regional and site stratigraphy are in Section 2.2 of Attachment 2. Figures 2.3, 3.1, and 3.2 of Attachment 2 show the bedrock within the site region and site area. Table 2.1 of Attachment 2 describes the stratigraphic units, further detailing the age, name, thickness, lithology, induration, relation to adjacent units, and geographic distribution.

\subsubsection{Structural setting}

The site is in the Colorado Plateau structural province, an intercontinental subplate with a thicker crust than adjoining provinces. Substructures within the plateau consist of broad basins containing thick Tertiary deposits and uplift structures with exposures of Precambrian basement rock. 
Details of the site structural setting are described in Section 2.3 of

Attachment 2. The regional structural elements (Figures 2.4 and 2.5 of Attachment 2) show the relationship of the site region to adjoining structural provinces.

The bedrock structure of the disposal site foundation is described in Section 3.1 of Attachment 2 and is illustrated on the geology map in Figure 3.1 of Attachment 2.

\subsubsection{Seismotectonics}

The DOE has characterized the potential for tectonic activity in local and regional structures that may contribute to earthquake generation and may affect the suitability of the site and design as follows.

\section{Seismicity}

The seismotectonic characteristics of the Colorado Plateau and adjacent provinces are given in Table 2.2 of Attachment 2. The maximum earthquake (ME) of the source area and the resultant acceleration at the site are shown in Table 2.5 of Attachment 2.

The historical seismicity of the region of all earthquakes of magnitude 3.0 or greater within a $93-\mathrm{mi}(150-\mathrm{km})$ radius of the site is presented in Table 2.4 of Attachment 2. This historical record is derived from the seismic data for a radius of $125 \mathrm{mi}(201 \mathrm{~km})$ from the site including the date, location coordinates, depth of focus, intensity, and magnitude. The original 1985 earthquake data file for this site have been updated by reference to the 1989 data file of the nearby Dry Flats site near Naturita, Colorado (NGDC, 1989) and an additional update for the area (NGDC/NOAA, 1994). Because the largest earthquake predicted or experienced within the western United States is a magnitude 8.2 event, the accepted attenuation/distance relationship for this event at a distance of $40 \mathrm{mi}(65 \mathrm{~km})$ is not expected to result in a peak horizontal acceleration (PHA) at the site that would exceed the PHA for a 6.2 magnitude event as a floating earthquake (FE) $9.3 \mathrm{mi}(15 \mathrm{~km})$ away. The $65-\mathrm{km}$ site radius is therefore considered appropriate for design purposes.

The seismic record is discussed in detail in Section 2.4 of Attachment 2. It describes seismic activity that is related to remote seismic source zones. A brief summary of the main points follows.

Seismicity for the site region, based upon credible locations of historical earthquakes and instrumentally located epicenters, has occurred mostly in the border zones of the Colorado Plateau and in the Intermountain Seismic Zone. The largest events recorded within the Colorado Plateau are in the range of magnitude 5.3 to 5.7 . The largest earthquake within a $125-\mathrm{mi}(201-\mathrm{km})$ radius was of magnitude $5.5130 \mathrm{mi}(210 \mathrm{~km})$ southeast of the site in the Rio Grande Rift area near the New Mexico-Colorado state line. Only one macroseismic 
earthquake occurred within the site region, with a magnitude 4.0 event in 1970 , at a distance of $33 \mathrm{mi}(53 \mathrm{~km})$.

The following information is the basis of the parameters used in designing the disposal cell to ensure stability against earthquake-induced instability (see Section 4.2 of Attachment 2).

\section{Tectonics}

Section 2.4 of Attachment 2 details the seismotectonic setting related to the structural geology of the region. The tectonic provinces are defined in Figure 2.4 of Attachment 2. These provinces are based on previously referenced studies of the region that present the correlation of structural features with seismic activity. Evidence of tectonic activity with the Colorado Plateau province and adjacent provinces (such as uplift or subsidence rates, evidence of active fault traces, and volcanism) are cited as characteristics of each province. Plate 2.1 of Attachment 2 shows the epicentral locations within a $40-\mathrm{mi}(65-\mathrm{km})$ site radius relative to the known fault systems within the site region. Important aspects of the regional tectonics are summarized below.

The interior portion of the Colorado Plateau province in which the disposal site is located is considered stable, with a more active border zone on its east, west, and south sides. Neogene faulting is rare within the interior. An exception is the Uncompahgre Uplift structure, where minor earthquakes have been associated with faults on its northeastern side and its southeastern terminus with the western mountains. These faults are located beyond the site region.

This information on the site region tectonics is the basis of the estimation of site-specific seismic design parameters.

\subsubsection{Resource development}

To ensure that future resource development will not jeopardize the remedial action, the occurrence of recoverable resources in the site area must be characterized. Resources of concern are those which, if exploited, could result in inadvertent intrusion into the disposal site.

Economic resources in the site region consist essentially of uranium and vanadium ore located within the Salt Wash Member of the Morrison Formation. The nearest mine is approximately $0.5 \mathrm{mi}(0.8 \mathrm{~km})$ southwest of the site in the Slick Rock uranium mining district.

The DOE has identified the resources occurring nearest the site, such as uranium ore and gas and oil deposits. Suspected uranium and vanadium ore zones 1 to $2 \mathrm{ft}(0.3$ to $0.6 \mathrm{~m})$ thick occur at depths of $900 \mathrm{ft}(300 \mathrm{~m})$ below the site. These ore deposits are not considered economically important resources at the present time because of the depressed uranium market. Based on the calculation for the impact of mining at that depth (presented in the 
appendix to Attachment 2), future resource development will not affect or be affected by the proposed remedial action.

Further details of the resources of the site and region are presented in Section 2.5 of Attachment 2. The locations of mineral resources are shown in Figures 2.7 and 2.8 of Attachment 2.

\subsection{SITE GEOLOGY}

Bedrock geological conditions at the site are characterized primarily to provide the basic information required for site geotechnical stability evaluations and ground water performance assessments. Surficial geologic conditions are characterized to establish the geomorphic history and processes at the site, and hence to determine that long-term stability standards will be met.

The procedures used to characterize site geology and the details of that site characterization are contained in Section 3.0 of Attachment 2. Figures 3.1 through 3.7 of Attachment 2 characterize the site geology and geomorphology through topographic base maps and cross sections. Salient site geologic features are described below.

\subsubsection{Bedrock geology}

The bedrock that underlies the site consists of shales and thin sandstones of the lower unit of the Dakota Sandstone, which is underlain by the mudstone/ claystone of the Burro Canyon Formation. The most significant strata in terms of hydrogeology are an upper sandstone at a depth of about $100 \mathrm{ft}(30 \mathrm{~m})$, a middle sandstone at a depth of about $200 \mathrm{ft}(60 \mathrm{~m})$, and a lower sandstone at a depth of about $300 \mathrm{ft}(90 \mathrm{~m})$. The cell will be founded in the mudstone, siltstone, and claystone strata of the lower Dakota Sandstone and the top of the Burro Canyon Formation.

\subsubsection{Surficial geology}

Surficial deposits on the approximately 18-ac (7.3-ha) mesa surface consist of thin soil covering the interior drainage basin of the site. Thickness ranges from less than $1 \mathrm{ft}(0.3 \mathrm{~m})$ at the perimeter to $4 \mathrm{ft}(1 \mathrm{~m})$ along the interior drainage swale. Because most of the surface area will be utilized in the cell design, the soil will be stripped to bedrock and stockpiled for other use. The surficial soils on and around the site are shown in Figure 3.7 of Attachment 2 and are discussed in Section 3.2 of Attachment 2. The DOE concludes that the surficial deposits will not detrimentally affect the long-term stability of the disposal cell.

\subsubsection{Geomorphology}

Site geomorphology is characterized to confirm the stability of the current landscape and to provide reasonable assurance that stability will be maintained 
for the performance period required by the standards. The DOE has characterized the regional and site geomorphology by referring to published literature, topographic maps, site inspections, and the procedures described in the TAD. Details of the regional geomorphology are provided in Section 2.1 of Attachment 2. Site-specific geomorphology is described in detail in Section 3.3 of Attachment 2. The main aspects of the geomorphology directly relevant to site remedial action are summarized below.

The site lies on a small mesa protected by outcrops of the resistant sandstone strata in the lower Dakota Sandstone. The rim of the mesa forms the drainage divide so that no off-site overland flow can occur. Drainage on the mesa is interior with only a single outlet founded on sandstone that occurs at the south rim. The principal geomorphic processes at the site are scarp retreat and head cutting. All tributary drainage around the mesa terminates on the exposed rock rim of the mesa. Natural armoring of the mesa slopes has developed from the detritus of the sandstone ledges.

The DOE has examined the geomorphic processes that could affect site stability and has described the geomorphic processes that created the landforms and that are likely to take place in the future (see Sections 2.1 and 3.3 of Attachment 2). This characterization is considered sufficient to assess the geomorphic stability of the site, as described in Section 2.4.1 of this report (where the DOE confirms that there is a reasonable assurance that stability will be maintained for the performance period of the design standards).

\subsection{GEOLOGIC STABILITY}

This section describes the local geologic and seismic conditions likely to affect the geotechnical stability of the disposal cell and the long-term stability of the landscape environment. It also analyzes the characteristics of unconsolidated deposits and geomorphic processes at the site that may affect long-term stability. In general, this section characterizes the suitability of the site geology including lithology, stratigraphy, and structural conditions as a foundation for the disposal cell.

\subsubsection{Geomorphic stability}

The DOE provides evidence of the long-term stability of the site in Section 3.0 and describes the stability that is expected for the performance period of the proposed remedial action in Section 4.0 of Attachment 2. The main aspects of the geomorphic stability of the site are discussed below.

The site has experienced long-term geomorphic stability. The topography indicates stable conditions are likely to continue for the performance period of the remedial action. The evidence for geomorphic stability is shown by the resistance of the cap rock sandstone to development of gullies on the mesa sideslopes and in the exit drainage of the mesa top. 
To enhance geomorphic stability, a minimum setback of $100 \mathrm{ft}(30 \mathrm{~m})$ from the edge of the mesa escarpment is recommended for the contaminated materials. Where the integrity of the mesa rim is encroached, the sideslopes will require placement of erosion protection rock. The central drainage exit at the south side should not be overlapped by the cell. The gully should be backfilled with material from the cell excavation to provide additional protection against the headward advance of this tributary.

The age of the geomorphic surfaces has been established in the preceding sections by reference to the rate of the scarp retreat. The DOE has identified and quantified geomorphic processes that could influence the disposal cell and remedial action. Specific projections relating to recommendations and engineering designs for site stability are presented regarding the potential for scarp retreat and headward advance of the tributaries. On the basis of these evaluations, the DOE concludes that the site is geomorphically stable and will continue to be for the performance period of the disposal cell.

\subsubsection{Seismotectonic stability}

The DOE has determined that the disposal site and designs will provide long-term stability during seismic events by developing an understanding of the anticipated ground motion at the site as a result of these events. Having catalogued the seismic activity, identified the significant geologic structures, and delineated the tectonic provinces, the DOE provides an analysis of the seismic sources that would most affect the stability of the site in Section 2.4 of Attachment 2. Each potentially active fault and the remote seismotectonic sources are shown in Table 4.1 of Attachment 2 and discussed in the text, with the calculated ME and the estimated ME of previous studies. Using appropriate attenuation relationships for the site region, the PHA for these sources and an FE are presented also. Only one fault system has been identified as having a critical potential acceleration relative to the FE as a design event. This fault system is determined to be noncapable so that the FE is determined to be the design earthquake.

The design earthquake for this site was determined to be an $M_{L}=6.2$ event occurring at a distance of $9.3 \mathrm{mi}(15 \mathrm{~km})$ from the site as an FE. The PHA of bedrock at the site is estimated to be 0.21 gravity $(\mathrm{g})$. Details of the studies leading to this conclusion are given in Section 4.2 of Attachment 2.

Specific seismic parameters to be used for the design are presented in the following design criteria section. These criteria were used in conjunction with appropriate soil strength parameters, pile geometry, and ground water information to assess slope stability. The geotechnical engineering aspects of the remedial action at the Slick Rock, Colorado, sites are presented in Section $\mathbf{3 . 0}$ of this document and in applicable calculation sets of Attachment 1 .

Seismic design parameters were derived using the procedures presented in Section 1.2 of Attachment 2. These procedures are set forth in the TAD 
(DOE, 1989). The acceleration attenuation relationship of Campbell (1981) was used to derive the on-site PHA.

\section{Design criteria}

The disposal cell is designed to include the criteria below:

- Long-term slope stability seismic coefficient: $K=0.14$ (0.66 of PHA).

- Short-term slope stability seismic coefficient: $K=0.11(0.5$ of PHA).

- Liquefaction analysis: ground surface horizontal acceleration $a_{\max }=0.21 \mathrm{~g}$.

Potential geologic conditions, including seismic shaking, liquefaction, on-site rupture, ground collapse, and volcanism, are ruled out as forces potentially disturbing to the disposal cell, either because they will not occur or because the geotechnical design of the cell is formulated to resist such forces.

\subsection{GEOLOGIC SUITABILITY}

On the basis of the site characterization described in this section and supporting documents, the details of the final RAP, and the provisions for stability included in the design of the disposal cell, the DOE concludes that there is reasonable assurance that regional and site geologic conditions have been characterized adequately to meet the requirements of 40 CFR Part 192. Conditions potentially affecting long-term stability have been identified and either avoided by design layout or mitigated by the details of the remedial action design. 


\subsection{GEOTECHNICAL ENGINEERING}

\section{$3.1 \quad$ INTRODUCTION}

This section and supporting references describe the geotechnical engineering aspects of the remedial action at the Slick Rock, Colorado, sites. The following aspects of the remedial action are described: geotechnical information related to the processing, borrow, and disposal sites; design details related to the disposal site and the disposal cell and its cover; and materials associated with the remedial action, including the foundation and excavation materials, tailings, and other contaminated materials. Related geologic aspects, such as site geology, geomorphology, and geomorphic and seismic characterization, are presented in Section 2.0. Surface water and erosion control are described in Section 4.0. Ground water conditions at the sites are described in Section 5.0.

SITE AND MATERIAL CHARACTERIZATION

\subsubsection{Geotechnical investigation}

Geotechnical investigations and site characterization programs were performed at both processing sites and at the disposal and borrow sites. The data obtained during these site characterization programs are presented in Attachment 1, Information for Bidders, Volumes I, II, III, and IV (September 1995). The geotechnical investigations included excavating test pits and augering boreholes. See Attachment 1, Drawing Nos. SRK-GE-10-0304 and SRK-PS-10-0318, SRK-PS-10-0325, and SRK-DS-10-0338, for the locations of test pits and boreholes. Test pit and borehole logs are compiled and included in Attachment 1, Information for Bidders, Volumes III and IV; and Appendix B of Attachment 3.

\section{Processing sites}

Tailings materials at the Slick Rock processing sites are located at the UC tailings pile and the NC tailings pile. Two site characterization programs were conducted at the processing sites. The pre-1987 program conducted by the TAC included 3 test pits at the NC pile and 19 test pits excavated at the UC pile. The DOE conducted additional subsurface investigations at the UC pile by augering 51 boreholes and performing 12 piezocone soundings. Another 26 boreholes were advanced at the NC site. Bulk samples were taken for laboratory analyses that required larger amounts of material.

Additional data were collected at the Slick Rock processing sites during investigations performed in 1987 and 1989. The TAC drilled another 13 boreholes at the UC site in 1989. The Remedial Action Contractor (RAC) also collected and analyzed soil samples from an additional 20 boreholes and 21 test pits at the UC site and 2 boreholes and 12 test pits at the NC site. All 
applicable logs from the processing site can be found in Attachment 1 , Information for Bidders, Volume III; and Appendix B of Attachment 3.

\section{Disposal site}

The DOE conducted the disposal area subsurface investigations, obtaining geotechnical data from 20 test pits excavated with a backhoe. The test pits were advanced to depths of 3 to $10 \mathrm{ft}(1$ to $3 \mathrm{~m})$. Additional geotechnical data were obtained during 1990 and 1993. Sixteen well boreholes and six core holes were advanced during 1990. The core holes were drilled to depths ranging from 80 to $430 \mathrm{ft}(20$ to $130 \mathrm{~m})$. Seven core holes and seven test pits were advanced during November 1993. The core holes were drilled to depths up to $37 \mathrm{ft}(11 \mathrm{~m})$, and the test pits were advanced to depths of $10 \mathrm{ft}(3 \mathrm{~m})$.

Disturbed and undisturbed samples were obtained from the boreholes using standard sampling and penetration techniques. Only disturbed samples of material were obtained from test pits. Test pit and borehole logs are compiled and presented in Attachment 1, Information for Bidders, Volume III; and Appendix B of Attachment 3.

\section{Potential borrow areas}

The DOE conducted numerous investigations of borrow areas. A total of 27 test pits ( 9 by the TAC and 18 by the RAC) were excavated and logged to characterize the soil at the proposed Disappointment Valley borrow site. All test pits were excavated using a backhoe. Bulk samples were collected at both borrow sites for laboratory determination of moisture content and the geotechnical characteristics of remolded samples. Laboratory testing later determined that fine-grained material from the excavation of the Burro Canyon disposal site is suitable as the radon barrier material and its use minimizes the overall environmental impact to the area. Samples of the erosion protection rock, ranging from gravel to cobble-sized material, were obtained from 23 test pits excavated in the Dolores River borrow sites located between the UC and NC piles. Two of the 23 test pits are located at the Troy Rose gravel pit. An additional rock borrow source is located about $0.2 \mathrm{mi}(0.4 \mathrm{~km})$ south of the UC mill site on the western bank of the Dolores River. Rock samples from this site were obtained from three deep test pits and three boreholes. Test pit logs are compiled and presented in Attachment 1, Information for Bidders, Volume IV; and Appendix B of Attachment 3.

\subsubsection{Testing program}

The materials at the Slick Rock processing sites were classified and tested. The testing program included sieve analysis (gradation), Atterberg limits, specific gravity, moisture density determinations, compaction and consolidation tests, determination of saturated hydraulic conductivity, percolation and water pressure tests, capillary moisture analysis, direct shear tests, and triaxial shear strength tests. The results of the individual tests are presented in 
Attachment 1, Information for Bidders, Volume IV. Summary tables and selected geotechnical design parameters are found in Attachment 1, Volume 1, Calculation No. 11-250-04-03.

\section{Disposal site foundation and borrow materials}

The DOE conducted the geotechnical engineering testing program for the Burro Canyon disposal site and proposed Disappointment Valley radon barrier borrow site, as well as the proposed radon barrier material from the Burro Canyon and Dolores River rock borrow sites. The test program for characterizing the disposal site foundation soils included performing field moisture and density tests in five test pits using the sand-cone method. Soil from depths of 3 to $10 \mathrm{ft}(1$ to $3 \mathrm{~m})$ below the surface were tested. Additional data on the disposal site foundation were obtained from laboratory testing of borehole samples taken from depths ranging from 20 to $90 \mathrm{ft}(6$ to $30 \mathrm{~m})$ below the ground surface. The proposed Disappointment Valley and Burro Canyon borrow site test programs (for radon barrier material) included soil classification and material properties testing. Testing included gradation, Atterberg limits, consolidation tests, saturated hydraulic conductivity, organic content, capillary moisture, triaxial shear strength, and moisture-density relationships. Rock durability tests and petrographic analyses were performed on rock from the Dolores River borrow sites. The durability tests performed were the Los Angeles abrasion, sulfate soundness, sodium adsorption and specific gravity, and Brazilian tensile strength tests. Petrographic analyses were performed as described by the American Society for Testing and Materials (ASTM) (ASTM, 1991). The results of the individual tests are contained in Attachment 1, Information for Bidders, Volumes III and IV.

\section{Conclusion}

All laboratory and field testing procedures followed the standards published by the ASTM or the U.S. Army Corps of Engineers, Engineering Manual EM 1110-2-1906 (USACE, 1970a). The testing program employed a sufficient number of samples and tests to define all critical soil parameters appropriate for support of the engineering analyses. In addition, the scope of the testing program and the use of resulting data to define material properties are in general conformance with the applicable provisions of the NRC SRP (NRC, 1985). Quality assurance $(Q A)$ and quality control $(O C)$ activities followed appropriate UMTRA Project procedures.

\subsubsection{Ground water conditions}

\section{Processing sites and rock borrow sites}

Three ground water systems are present in the vicinity of the UC and NC sites and the proposed rock borrow sites: 1) the unconfined Dolores River alluvium, 2) the semiconfined to confined Entrada Formation, and 3) the semiconfined to confined Navajo Sandstone. These three hydrostratigraphic units may be locally 
interconnected in the vicinity of the processing sites. Additional information is provided in Section 5.1 of this document.

\section{Disposal site/Burro Canyon borrow material site}

Four hydrostratigraphic units consisting of one unsaturated unit and three saturated units underlie the Burro Canyon disposal site. The unsaturated hydrostratigraphic unit is the lowest unit of the Dakota Sandstone and the uppermost Burro Canyon Formation claystones and mudstones. The three saturated sandstone units are within the Burro Canyon Formation at approximate depths of 100,200 , and $300 \mathrm{ft}(30,60$, and $90 \mathrm{~m})$, and are described as the upper, middle, and lower sandstone units, respectively. The upper sandstone unit of the Burro Canyon Formation is the uppermost aquifer underlying the disposal cell footprint. This unit is characterized by low yield and limited use. Ground water movement in the upper sandstone unit is unconfined. Ground water in lithologic units underlying the upper sandstone unit is protected from potential site-related contamination by 1 ) hydrogeologic isolation provided by the low permeability mudstone units that inhibit the downward migration of water, and 2) upward vertical hydraulic gradients in the confined lower and middle sandstone units of the Burro Canyon Formation.

\subsubsection{Site stratigraphy}

\section{Processing sites}

The UC site lies on a bench of Entrada Formation with a thin, probably discontinuous Quaternary terrace gravel cover and overlaps the bedrock bench toward the river onto a thicker, younger gravel deposit. The NC site lies partially on sandstone and mudstone of the Salt Wash Member of the Morrison Formation and partially on Quaternary terrace gravels.

At Slick Rock, the slimes were removed for processing at Rifle, Colorado, leaving only sand tailings. Tailings in the UC pile generally contain less than 15 percent fines, while samples of NC tailings contain generally less than 5 percent fines.

\section{Disposal/borrow site}

The soil at the Burro Canyon disposal site consists of reddish-brown, sandy clay to clayey sand with thicknesses ranging from 0 to $1.5 \mathrm{ft}(0$ to $0.46 \mathrm{~m})$ at the perimeter of the mesa top to 0.25 to $4.5 \mathrm{ft}(0.076$ to $1.4 \mathrm{~m})$ in the middle of the site. In most places, the soil is directly underlain by a thin sandstone stratum. In a few locations, the soil covers a dark-gray, carbonaceous shale/claystone. The lower Dakota Sandstone and the upper unit of the Burro Canyon Formation form the foundation at the site. A more detailed discussion of the stratigraphy and geology of the disposal site is presented in Section 2.0 and Attachment 2. 


\section{Additional borrow sites}

The proposed borrow sites for riprap and gravel are adjacent to the Dolores River. The stratigraphy of the sites is generally sand overlying a moderately thick river terrace deposit. The terrace deposits contain subrounded, gravel-size particles and subrounded cobbles ranging in size from 6 to 8 inches $(200 \mathrm{~mm})$ in diameter. Based on the site characterization data and flood and floodplain analyses, the terrace deposits should contain a sufficient quantity of largediameter rock to construct the erosion protection features of the Burro Canyon disposal cell.

\subsection{GEOTECHNICAL ENGINEERING EVALUATION}

\subsubsection{Introduction}

This section and the supporting documents referenced in Table 1.2 present the engineering evaluation of the information and analyses that were undertaken to demonstrate that the proposed remedial action design will meet the EPA standards for long-term stability, including slope stability, settlement, liquefaction, and cover cracking. The analyses were performed for design-basis events such as the design earthquake, the design flood, and extreme meteorological conditions.

\subsubsection{Slope stability}

The geotechnical stability of the disposal embankment slopes was evaluated. The most critical slope sections were analyzed for the short-term, end-of-construction state and the long-term state. Excavation slopes were evaluated to ensure stability during construction. A brief description follows of the work that supports these conclusions.

\section{Disposal cell slopes}

A plan of the pile layout and the location of the most critical sections are presented in Attachment 1, Calculation No. 11-310-01-00. Soil parameters for the compacted tailings and radon barrier were established by appropriate testing of representative material. Values of soil parameters for the select fill, riprap, and foundation materials were assigned, based on published data and data obtained from the geotechnical explorations at the site. Soil parameters used for the evaluation are presented in Attachment 1, Calculation No. 11-250-04-03.

The Modified Janbu Method and infinite slope methods were employed to assess the conditions to which the critical slope might be subjected. Results are shown in Table 3.1. Factors of safety against slope failure were analyzed for both static and seismic loading conditions. The seismic stability of the slope was investigated by the pseudostatic method of analysis using horizontal seismic coefficients of 0.11 for the short-term case and 0.14 for the long-term 
Table 3.1 Results of slope stability analysis, Slick Rock, Colorado, site

\begin{tabular}{|c|c|c|c|c|c|}
\hline \multirow[b]{2}{*}{ Case } & \multirow{2}{*}{$\begin{array}{l}\text { Loading } \\
\text { condition }\end{array}$} & \multicolumn{2}{|c|}{$\begin{array}{l}\text { Required factor of } \\
\text { safety }\end{array}$} & \multirow{2}{*}{$\begin{array}{l}\text { Short-term } \\
\text { conditions } \\
\text { (EOC) }\end{array}$} & \multirow[b]{2}{*}{$\begin{array}{l}\text { Long-term } \\
\text { conditions }\end{array}$} \\
\hline & & Short-term & Long-term & & \\
\hline Excavation slope & Static & 1.3 & 1.5 & 1.3 & 1.5 \\
\hline Embankment slope & $\begin{array}{l}\text { Static } \\
\text { Seismic }\end{array}$ & $\begin{array}{l}1.3 \\
1.0\end{array}$ & $\begin{array}{l}1.5 \\
1.0\end{array}$ & $\begin{array}{l}3.03 \\
2.02\end{array}$ & $\begin{array}{l}3.00 \\
1.84\end{array}$ \\
\hline Infinite slope (shallow plane) & $\begin{array}{l}\text { Static } \\
\text { Seismic }\end{array}$ & $\begin{array}{l}1.3 \\
1.0\end{array}$ & $\begin{array}{l}1.5 \\
1.0\end{array}$ & $\begin{array}{l}2.67 \\
1.85\end{array}$ & $\begin{array}{l}6.32 \\
4.00\end{array}$ \\
\hline
\end{tabular}

${ }^{a}$ As specified by the TAD (DOE, 1989).

EOC - end of construction.

case. Pseudostatic methods are considered acceptable because of the conservatism employed in determining soil parameters and seismic coefficient values. Minimum requirements for the static loading conditions and seismic loading conditions are specified in the TAD (DOE, 1989).

\section{Excavation slopes}

The excavation slopes will be 1 horizontal to 1 vertical $(1: 1)$ along the disposal cell perimeter. Soil parameters for the disposal area foundation material were assigned on the basis of data obtained from geotechnical explorations and published data; they are presented in Attachment 1, Calculation No. 11-25004-03. A minimum 1.3 safety factor against failure was determined for the temporary (during construction) excavation slope, and a safety factor of 1.5 was calculated for the permanent (post-construction) slope. The analysis of the excavation slope stability is presented in Attachment 1, Calculation No. 11-310-02-00.

\section{Conclusion}

The methods of analysis employed are considered to be conservative approaches and satisfy the requirements in the TAD (DOE, 1989). In addition, the most critical conditions to which the slopes might be subjected have been considered and the characteristics of all slopes have been well defined. From the results of the slope stability evaluation, it can be concluded that the embankment slopes would be stable under short-term and long-term conditions, and thus would comply with the EPA standard 40 CFR \$192.02(a) for long-term stability.

\subsubsection{Settlement}

As a result of volume changes in the tailings and foundation materials, differential settlement of the disposal cell was evaluated to determine the 
potential for disruptive conditions such as surface water flow concentration, ponding, or cracking of the radon barrier cover. The locations evaluated were chosen to determine the range of total and differential settlements across the cell. A detailed analysis of settlement is presented in Attachment 1. Calculation No. 11-323-01-01.

Soil parameters for the radon barrier and compacted tailings were determined from appropriate testing of representative material. The other materials, including the select fill and foundation, were assigned soil parameter values on the basis of data obtained from geotechnical investigations and published data.

The amount of primary and secondary settlement and the time rates of primary settlement that will occur at specified locations of the disposal cell were calculated. The secondary consolidation at different locations was compared to determine long-term differential settlement gradients across the interface. Based on the results of this analysis (see Attachment 1, Calculation No. 11-323-01-01), the cover will not experience cracking, nor will water collect on the top of the embankment.

\subsubsection{Liquefaction potential}

For liquefaction to occur, a soil must be saturated, loose, and cohesionless. Both the compacted tailings and foundation material satisfy the cohesionless criterion, but because of an infiltration-inhibiting radon/infiltration barrier and a depth of 80 to $150 \mathrm{ft}(20$ to $50 \mathrm{~m})$ to ground water, the tailings and foundation material will not become saturated. In addition, neither the compacted tailings nor the medium dense-to-dense foundation material can be considered loose. Therefore, the stabilized tailings embankment is not susceptible to liquefaction.

\subsubsection{Cover design}

Figure 1.5 shows a cross section of the cover system. A more detailed layout of the cover system is shown in Attachment 1, Drawing Nos. SRK-DS-10-0335 and SRK-DS-10-0336. The design for the disposal embankment cover consists of the following layers, descending from the top: an 8-inch $(200-\mathrm{mm})$-thick layer of riprap; a 6 -inch $(150-\mathrm{mm})$-thick sand/gravel layer; a $2.0-\mathrm{ft}(0.61-\mathrm{m})-$ thick frost protection layer; and a $1.5-\mathrm{ft}(0.45-\mathrm{m})$-thick radon barrier. The only difference between the top and sideslope covers is that the riprap layer on the sideslope will be $1.0 \mathrm{ft}(0.30 \mathrm{~m})$ thick. Cover component material types and functions are listed in Table 3.2.

\section{Conclusion}

The material properties and available quantities for the cover materials have been adequately defined in a manner that conforms with the applicable provisions of the SRP. In addition, the performance of the cover system has been evaluated using both state-of-the-art techniques and standard engineering methods; the result is that the cover will remain effective for a period of time 
Table 3.2 Cover components and their functions

\begin{tabular}{|c|c|c|}
\hline Cover component & Material type & Function \\
\hline Erosion protection layer & Riprap & $\begin{array}{l}\text { Prevents erosion of the disposal cell by } \\
\text { surface water runoff. }\end{array}$ \\
\hline \multirow[t]{3}{*}{ Bedding layer } & Sand/gravel & $\begin{array}{l}\text { Prevents displacement of large- } \\
\text { diameter rock. }\end{array}$ \\
\hline & & $\begin{array}{l}\text { Protects frost-protection layer (fine- } \\
\text { grained material) from erosion. }\end{array}$ \\
\hline & & Drains water laterally. \\
\hline Frost protection layer & $\begin{array}{l}\text { Fine-grained soil } \\
\text { with some sand }\end{array}$ & $\begin{array}{l}\text { Protects the radon/infiltration barrier } \\
\text { from the effects of freezing and } \\
\text { thawing. }\end{array}$ \\
\hline \multirow[t]{2}{*}{ Radon barrier } & Sandy clay & Inhibits radon emissions. \\
\hline & & $\begin{array}{l}\text { Inhibits infiltration through the } \\
\text { underlying contaminated material. }\end{array}$ \\
\hline
\end{tabular}

that is in compliance with the EPA standard for long-term performance (40 CFR $\S 192.02$ ).

\subsubsection{Subsidence}

Because mining may take place beneath the Burro Canyon disposal site in the future, the potential exists for subsidence of the foundation soil of the disposal cell footprint. The potential effect of subsidence on the stability of the disposal cell was assessed in the appendix to Attachment 2, TAC Calculation No. SRK04-90-03-03-00. Based on previous mining practices in the area and conservative assumptions for analysis, future uranium and vanadium mining of the Upper Salt Wash Formation will not adversely affect the long-term stability of the disposal cell at Burro Canyon. The top of the Upper Salt Wash Formation is approximately $900 \mathrm{ft}(300 \mathrm{~m})$ below the surface of the Burro Canyon disposal site.

\subsection{CONSTRUCTION DETAILS}

\subsubsection{Construction methods and features}

Detailed descriptions of the remedial action are provided in Attachment 1, including site plans and engineering drawings that convey the remedial action design features and construction specifications that provide a detailed explanation of the proposed construction methods. In addition, Attachment 1, Calculations, Volumes I through VI, contains calculations that support the remedial action design features and volumes of materials. 
Remedial action will meet the following general construction requirements:

- The partially below-grade disposal cell will be excavated through Dakota Sandstone into the claystones and mudstones of the Burro Canyon Formation. Most of the Dakota Sandstone and the mudstone/claystone of the Burro Canyon Formation are considered to be rippable by large bulldozers, but some limited blasting may be required. Excavation of the disposal cell will be monitored and evaluated on the site by a geologist to limit the amount of blasting.

- The maximum percentage of organics contained within the reshaped disposal cell should not exceed 5 percent by volume, and the material should be distributed so as to avoid pockets or layers of organic matter.

- All uncontaminated vegetation and organic material in areas subject to excavation and placement should be removed and disposed of off the site.

- Contaminated demolition debris should be reduced to manageable pieces and carefully placed in the embankment to ensure that voids and nesting do not occur around the debris and that the adjacent contaminated materials are compacted to 90 percent of the Standard Proctor density (ASTM D69890) (ASTM, 1991).

- Excavation of all contaminated materials should be monitored carefully to prevent the inclusion of unnecessary, uncontaminated material in the pile.

- The surfaces of all areas where fill materials will be placed should be proof-rolled before placement of contaminated materials. Soft zones should be excavated and replaced with compacted material.

- The relocated tailings and contaminated materials should be compacted to at least 90 percent of the Standard Proctor density (ASTM D698-90) (ASTM, 1991) and should be moisture-conditioned or dried to specified moisture content to achieve specified density.

- Design criteria for the radon barrier cover include 1) placement at a minimum of 95 percent of the Standard Proctor density (ASTM D698-90) (ASTM, 1991), 2) placement at or above the optimum moisture content, and 3) compaction by a kneading method.

\subsubsection{Testing and inspection}

Attachment 1, Subcontract Documents, details the methods, procedures, and frequencies by which construction materials and activities will be tested and inspected to verify compliance with the design specifications.

Quality will be controlled in accordance with the UMTRA QA plan (DOE, 1993). The DOE and the TAC will conduct $Q A$ audits and an in-process surveillance to 
verify and ensure that remedial action activities are performed in accordance with approved UMTRA Project requirements.

\subsubsection{Construction activities and construction sequence}

\section{General}

Construction activities will take place at the following locations: the existing tailings sites (UC and NC sites), areas contaminated by windblown and waterborne tailings, and the Burro Canyon disposal site.

During remedial action construction, all contaminated runoff will be contained. Contaminated disturbed areas at the UC site will be graded so that runoff flows to a retention basin. Construction at the NC site will occur over a short period and during the dry early summer months; therefore, collection ditches and a wastewater retention basin will not be required. Uncontaminated disturbed areas will be graded to divert runoff from contaminated areas.

Ditches at the UC site and the Burro Canyon disposal site will be sized to carry the peak runoff flows from a 10-year storm event. They will serve to divert uncontaminated runoff away from the sites and to divert contaminated runoff to the retention basins for temporary storage or treatment and discharge.

The retention basins will receive water from contaminated areas and decontamination activities, including equipment and truck washdowns. The retention basins at the processing site and the disposal site are designed to retain the runoff from a 10-year, 24-hour storm; the maximum accumulated volume in the basin due to the average monthly runoff; wastewater generated from the remedial action activities; and all sediment inflow during the remedial action.

The emergency spillways from the basins are designed to discharge the 25-year, 6-hour storm runoff while $1 \mathrm{ft}(0.3 \mathrm{~m})$ of freeboard is maintained between the tops of the embankments and the maximum water surface. Normally, a wastewater discharge will not be necessary during the construction period. However, if an event greater than the 10-year storm occurs, wastewater may have to be discharged from the retention ponds. The characteristics of any wastewater or storm water to be discharged from the ponds will be specified in applicable federal and state permits.

\section{Wastewater treatment}

Wastewater will be directed to the retention basin to provide primary settling as well as flow and contaminant equalization. Any water remaining in the retention basin may be treated further if a discharge is required. Also, water collected in the retention basin will be used only for dust control within contaminated areas and for compaction of contaminated material. 


\section{Equipment decontamination pad}

To prevent contaminated materials from being carried out of the construction areas, decontamination pads with a holding pond and a pump will be provided at the UC and NC sites, and the Burro Canyon disposal site to wash contaminated equipment, as required.

\section{Dust control}

Dust generated by excavating, earthmoving, vehicle use, temporary material stockpiling, and other activities will be controlled and minimized by the use of water and water-based surfactants. Only uncontaminated water will be used to control dust in uncontaminated areas.

Water recycled from the wastewater retention ponds will be used to suppress dust created by stockpiling and working with contaminated materials.

\section{Construction sequence}

The following construction sequence is proposed for the remedial action. The final schedule will contain more details and the construction subcontractor will be allowed flexibility in the final construction sequence. Activities are presented in the order in which they should occur, although some events will be concurrent.

1. Erect site perimeter fences and remove existing fences.

2. Perform clearing and grubbing at the UC, NC, and Burro Canyon sites.

3. Start excavating the Burro Canyon disposal cell foundation. Stockpile soils removed for later use as cover/radon barrier material.

4. Construct, upgrade, and maintain access roads to the NC and Burro Canyon sites, including excavations at the junction of the Burro Canyon site access road and Highway 141.

5. Excavate and stockpile contaminated materials from access control and decontamination pad areas in the UC and NC sites.

6. Construct access control areas and decontamination pads at the UC, NC, and Burro Canyon sites.

7. Construct the temporary bypass road at the UC site.

8. At the UC and Burro Canyon sites, construct retention basins and temporary drainage ditches. Stockpile contaminated materials excavated at the UC site during this process for later disposal in the tailings embankment; stockpile excavated uncontaminated materials for later use as 
fill. Perform grading required for site drainage. At the NC and Burro Canyon sites, construct silt fences.

9. Demolish abandoned structures and utilities encountered and stockpile the debris of the UC site for haul to the Burro Canyon site.

10. Clean up windblown/waterborne contamination at the UC site, including the small area west of the bridge and the gas line right-of-way. Stockpile material within the fenced area or haul to the Burro Canyon site.

11. Complete preparation of the tailings embankment foundation.

12. Excavate and transport the NC contaminated materials, including demolition debris, to the Burro Canyon embankment.

13. Demolish the temporary facilities at the NC site and perform final site grading of the NC area.

14. Excavate and transport the UC-contaminated materials to the tailings embankment.

15. Seal existing monitor wells.

16. Demolish decontamination and wash facilities, including the decontamination pad sump, and dispose of the debris in the tailings embankment.

17. Dispose of contaminated sediments from the temporary drainage ditches and the washwater retention basins of the UC and Burro Canyon areas in the tailings embankment, as required, and dispose of the synthetic membrane liner.

18. Construct the $1.5-\mathrm{ft}(0.45-\mathrm{m})$-thick radon barrier cover over the contaminated material in the tailings embankment.

19. Construct the $2-\mathrm{ft}(0.45-\mathrm{m})$-thick frost protection layer over the radon barrier.

20. Place erosion protection materials over the frost protection barrier. The erosion protection materials shall consist of a 6 -inch $(150-\mathrm{mm})$-thick layer of bedding material topped by a layer of rock riprap.

21. Remove and dispose of the subcontractor's stockpiled material and remove the site perimeter fencing.

22. Grade and restore the Burro Canyon and UC sites to provide drainage, including placement of uncontaminated fill, conditioning, and revegetation. 


\section{Schedule}

Remedial action began on 15 March 1995. Winter shutdown periods may be up to 5 months. The proposed construction schedule is shown in Figure 3.1, but it may be refined during the final design process.

\section{$3.5 \quad$ SUMMARY}

Geotechnical engineering and construction evaluations were conducted using common engineering practices and commonly accepted techniques. These evaluations extended to levels of detail that are in general conformance with applicable provisions of the NRC SRP for UMTRA Project Title I mill tailings RAPs. Evaluation of the previous results show that the proposed remedial action design will comply with EPA standard 40 CFR Part 192, Subpart A, for geotechnical engineering and construction. 


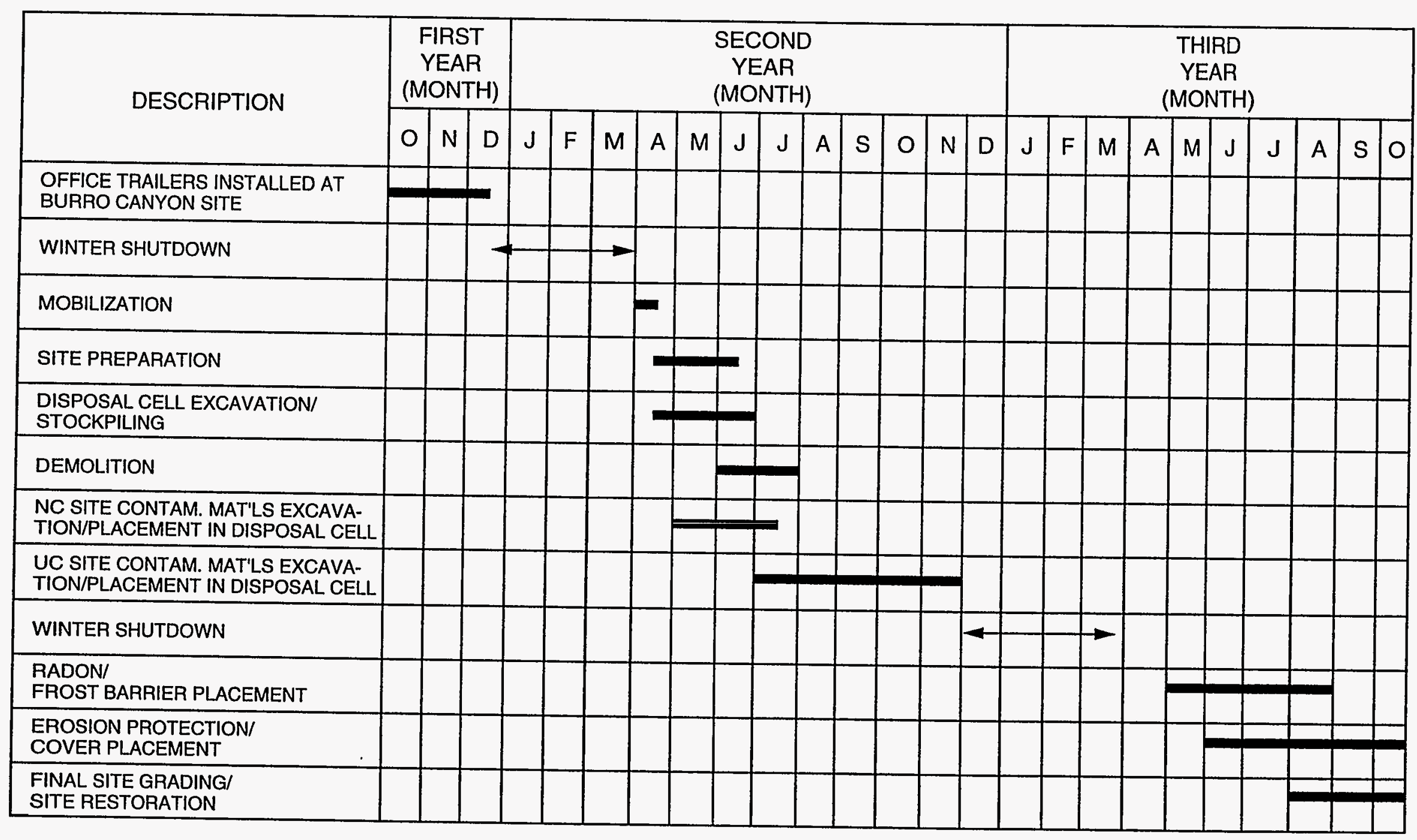

FIGURE 3.1

REMEDIAL ACTION SCHEDULE SLICK ROCK, COLORADO, SITES 


\subsection{SURFACE WATER HYDROLOGY AND EROSION PROTECTION}

\subsection{HYDROLOGIC DESCRIPTION AND REMEDIAL ACTION DESIGN}

The elevations of the Burro Canyon disposal site range from 5870 to $5912 \mathrm{ft}$ (1790 to $1802 \mathrm{~m}$ ) above MSL. The disposal site is on a small mesa completely isolated from runoff from upland drainages. The drainage north and east of the site is the Nicholas Wash Basin. The disposal site and basins south of the site drain into Joe Davis Canyon. Runoff in the two shallow drainages in the center of the site (mesa) drains by sheet flow until it reaches the south edge of the mesa; there the flow concentrates into a well-defined gully that incises the rim. Flooding is not considered a hazard at the Burro Canyon disposal site because of its distance from and elevation above the closest stream channel. The drainage characteristics of the Burro Canyon disposal site are illustrated in Figure 4.1.

The erosion protection riprap on the topslopes and sideslopes of the disposal cell will be sized to withstand an on-cell probable maximum precipitation (PMP) storm runoff. The cell also will be protected by a $20-\mathrm{ft}(6-\mathrm{m})$-wide, $5-\mathrm{ft}(2-\mathrm{m})-$ deep apron along the toe of the sideslopes. The areas surrounding the disposal cell will be backfilled as required, graded to control surface drainage, and seeded.

\subsection{FLOODING DETERMINATIONS}

To determine the impact of flooding to the sites, the DOE calculated peak flows and velocities and evaluated the need for erosion protection features. All erosion protection features must withstand extreme meteorologic events such as the PMP.

\subsubsection{Probable maximum precipitation}

The determination of the site design PMP is presented in Attachment 1 , Calculation No. 11-315-01-00. A local thunderstorm PMP of approximately 8.1 inches $(210 \mathrm{~mm})$ in 1 hour is calculated for a small upland watershed (i.e., the disposal site). The PMP rainfall estimate was developed using Hydrometeorological Report No. 49 (NOAA, 1977).

\subsubsection{Infiltration losses}

In computing the peak flow rate for the design of the rock erosion protection for the disposal cell top, sideslopes, and toe apron, the DOE assumed no infiltration would occur. This estimate is conservative with respect to erosion protection design (see Attachment 1, Calculation Nos. 11-322-01-00 and 11-322-02-01). 


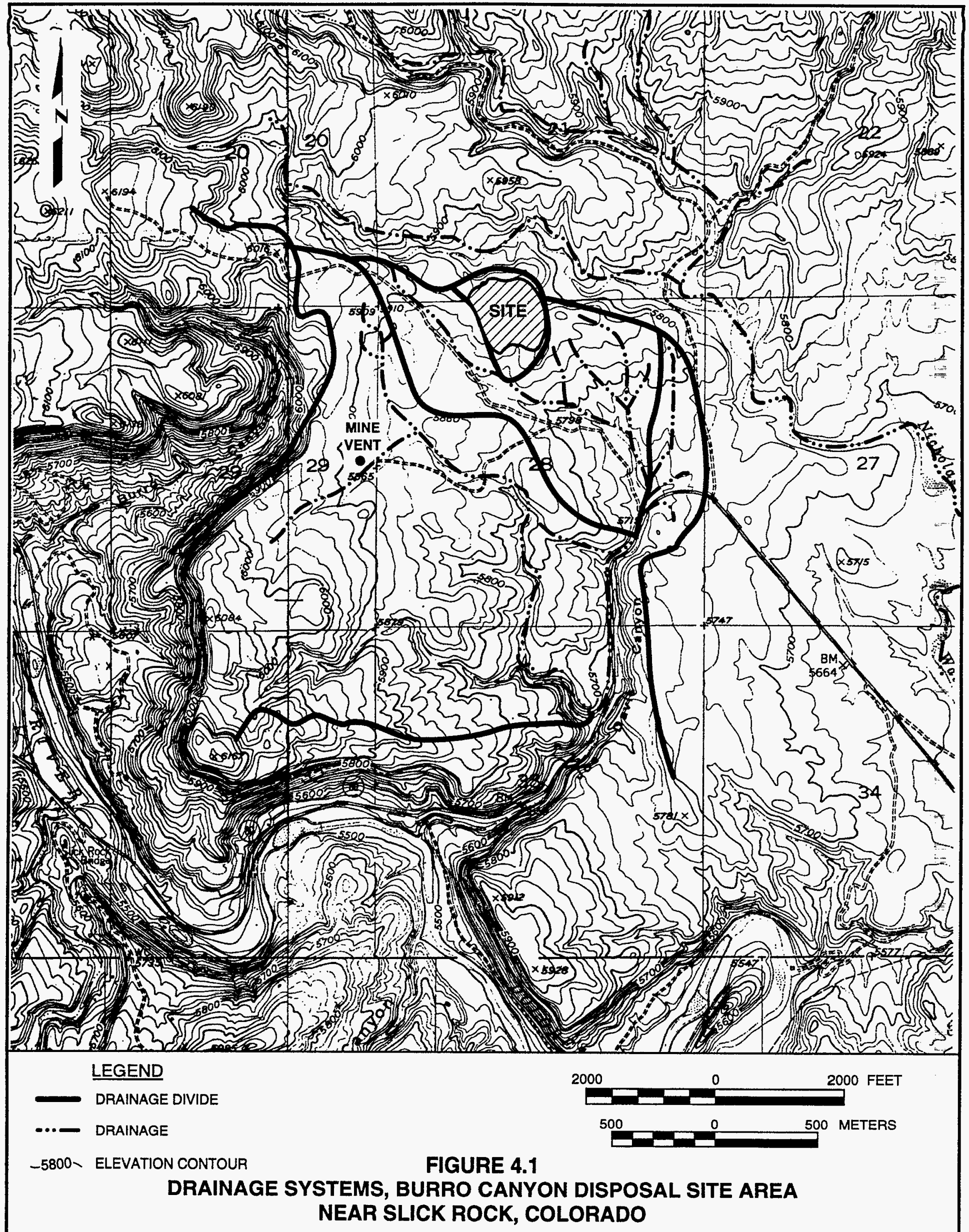




\subsubsection{Time of concentration}

The time of concentration $\left(T_{c}\right)$ is the time required for runoff to reach the outlet of a drainage basin, starting from the most remote point in that basin. For a given volume of runoff, the peak runoff for a given drainage basin (area) is inversely proportional to the $T_{c}$ for that basin. If the $T_{c}$ is conservatively computed to be small, the peak discharge will be conservatively large.

The $T_{c}$ for the topslopes and sideslopes was determined by dividing the slope lengths by the estimated flow velocities. The flow velocities were determined using the Manning Equation. For the design rock size and a critical path length of $130 \mathrm{ft}(40 \mathrm{~m})$, the $T_{c}$ for the topslope is 2.0 minutes; however, a minimum $T_{c}$ of 2.5 minutes is used in all applicable calculations. The $T_{c}$ for the sideslope is 3.2 minutes for a critical path length of $340 \mathrm{ft}(104 \mathrm{~m})$. The $T_{c}$ 's are included in Attachment 1. Calculation Nos. 11-322-01-00 and 11-322-02-01.

\subsubsection{Rainfall distributions-probable maximum precipitation}

The DOE derived PMP rainfall depths and intensities from Hydrometeorological Report No. 49 (NOAA, 1977). The temporal distribution of the PMP depths and intensities was performed in accordance with the procedure described in the TAD (DOE, 1989).

\subsubsection{Computation of probable maximum flood}

\section{Adjacent waterways}

Because the disposal site is on a small mesa, flooding in adjacent waterways will not impinge on the disposal cell. In addition, no upland drainages contribute runoff toward the site.

\section{On-site drainage}

The Rational Formula and PMP rainfall intensity were used to determine the peak flow rates. Peak unit flow at the end of the topslope is 0.158 cubic feet per second per $\mathrm{ft}\left(\mathrm{ft}^{3} / \mathrm{s} / \mathrm{ft}\right)\left(0.0147\right.$ cubic meters per second per meter $\left.\left[\mathrm{m}^{3} / \mathrm{s} / \mathrm{m}\right]\right)$. Peak unit flow for the sideslope and the toe apron is $0.39 \mathrm{ft}^{3} / \mathrm{s} / \mathrm{ft}$ (Attachment 1, Calculation Nos. 11-322-01-00 and 11-322-02-01).

\subsection{FLOW DEPTH AND VELOCITIES}

\subsubsection{Adjacent waterways}

Because the disposal cell is on a small mesa that is much higher than the surrounding terrain, flooding in adjacent waterways will not impinge on the site. Therefore, analyses of adjacent waterways were not necessary. 


\subsubsection{Drainage ditches}

Because of the disposal cell's location, no permanent drainage or interceptor ditches are required at the Burro Canyon disposal site. A naturally formed swale at the southern end of the mesa will be filled and graded (10 percent maximum) to facilitate drainage from the top-and sideslopes of the disposal cell.

\subsubsection{Top and sides of the embankment}

Manning's Equation was used to estimate a flow depth based on the peak sheet flow rate, slope, and an assumed Manning's $n$ value. The appropriateness of the assumed Manning's $n$ then was checked using the U.S. Army Corps of Engineers equation (USACE, $1970 \mathrm{~b}$ ). Based on the calculated $D_{50}$ rock size, the flow depth and velocity at the end of the topslope will be approximately $0.10 \mathrm{ft}(30 \mathrm{~mm})$ and $1.51 \mathrm{ft} / \mathrm{s}(0.46 \mathrm{~m} / \mathrm{s})$, respectively. For the $4: 1$ sideslopes, the calculated flow depth and velocity are $0.11 \mathrm{ft}(33 \mathrm{~mm})$ and $3.6 \mathrm{ft} / \mathrm{s}$ $(1.16 \mathrm{~m} / \mathrm{s})$, respectively (see Attachment 1, Calculation No. 11-322-01-00).

The slope of the toe transitions from 25 percent on the sideslopes to a 2-percent apron slope. Based on the design $D_{50}$ rock size, the flow depth and mean flow velocity over the toe apron will be $0.12 \mathrm{ft}(0.037 \mathrm{~m})$ and $3.17 \mathrm{ft} / \mathrm{s}$ $(0.97 \mathrm{~m} / \mathrm{s})$, respectively (see Attachment 1, Calculation No. 11-322-02-00).

\subsection{EROSION PROTECTION}

\subsubsection{Topslopes}

The surface layer of riprap on the topslope, which is designed to protect the disposal cell from wind and water erosion, has been sized to withstand the erosive velocities resulting from an on-pile PMP. The DOE proposes to use an 8 -inch $(200-\mathrm{mm})$-thick layer of rock with a required $D_{50}$ of 1.7 inches $(43 \mathrm{~mm})$. The riprap will be placed on a 6 -inch $(150-\mathrm{mm})$-thick bedding layer. The safety factor method was used to determine the appropriate rock size for the topslope. A detailed discussion of rock sizing, including gradation information, is presented in Attachment 1. Calculation Nos. 11-322-01-00 and 11-322-03-00.

\subsubsection{Sideslopes}

The rock layer on the sideslopes, which also protects the disposal cell from wind and water erosion, is designed to withstand an occurrence of the local on-pile PMP. The DOE proposes to use a 1-ft $(0.3-\mathrm{m})$-thick layer of rock with a required $D_{50}$ of approximately 4 inches $(100 \mathrm{~mm})$. The $D_{50}$ rock size where the sideslope transitions to the toe apron will be 5.8 inches $(150 \mathrm{~mm})$. The rock layer will be placed on a $0.5-\mathrm{ft}(0.2-\mathrm{m})$ bedding layer. Stephenson's Method was used to determine the required rock sizes. The gradation and required thickness of cover layers are presented in Attachment 1, Calculation No. 11-322-01-00. 


\subsubsection{Toe and sides of the embankment}

At the toe of the disposal cell, the DOE will place a 20-ft (6-m)-wide, 5-ft (2-m)-deep layer of rock, with a minimum $D_{50}$ rock size of 5.8 inches $(145 \mathrm{~mm})$. Rock in the toe apron will be placed on a 6-inch $(150-\mathrm{mm})$-thick sand/gravel bedding layer (see Attachment 1, Calculation No. 11-322-02-01). Several methods were used to estimate the rock size required for the toe apron, including the safety factors method (Stevens et al., 1976), the U.S. Army Corps of Engineers Stilling Basin Method (USACE, 1965), and the Stephenson Method (Stephenson, 1979). The toe apron is designed to protect against local scour due to runoff from a PMP event. Erosion protection requirements are presented in Table 4.1.

Table 4.1 Rock size requirements and layer thicknesses for the Burro Canyon, Colorado, disposal cell

\begin{tabular}{|c|c|c|c|c|c|}
\hline \multirow[b]{2}{*}{ Location and grade } & \multicolumn{3}{|c|}{ Rock size requirement } & \multicolumn{2}{|c|}{ Layer thickness } \\
\hline & Rock size & (inches) & (mm) & (inches) & $(\mathrm{mm})$ \\
\hline Topslopes $(2 \%)$ & $D_{50}$ & 1.7 & 43 & 8 & 200 \\
\hline Sideslopes $(25 \%)^{a}$ & $D_{50}$ & 4.0 & 100 & 12 & 300 \\
\hline Toe protection & $D_{50}$ & 5.8 & 150 & 60 & $1.5 \mathrm{~m}$ \\
\hline
\end{tabular}

\subsection{ROCK DURABILITY}

The proposed rock borrow sites are within $5 \mathrm{mi}(8 \mathrm{~km})$ of the Burro Canyon disposal site. These sources are adjacent to the Dolores River and near the UC and NC sites. The gravel and riprap from the selected borrow sites were tested in accordance with the methods and tests described in NUREG/CR-2642 (Lindsey et al., 1982). The average score of the tested material was 77. A total of 14 samples were tested and complete results of the tests are presented in Attachment 1, Calculation No. 11-231-02-02.

\subsection{QUALITY CONTROL TESTING AND INSPECTION FOR EROSION PROTECTION}

Attachment 1 provides details of testing and inspection procedures.

\subsection{UPSTREAM DAM FAILURES}

McPhee Dam is approximately $36 \mathrm{mi}(58 \mathrm{~km})$ (linear distance) upstream of the Burro Canyon disposal site. Based on a flood and floodplain analysis of the Dolores River that included a dam-break scenario, a local PMP event by itself would cause much higher water levels in the Dolores River near Slick Rock than a catastrophic failure of the McPhee Dam and the subsequent release of 
impounded water. As the Burro Canyon disposal site is nearly $400 \mathrm{ft}(100 \mathrm{~m})$ higher than the invert elevation of the Dolores River, it will not be affected by the probable maximum flood or a breach of the McPhee Dam.

\subsection{SUMMARY}

The DOE concludes that the Burro Canyon disposal cell design will meet EPA requirements as stated in 40 CFR Part 192 with regard to flood design measures and erosion protection. An adequate hydraulic design has been provided to reasonably ensure stability of the contaminated material and tailings for a period of up to 1000 years. 


\subsection{WATER RESOURCES PROTECTION}

The DOE must demonstrate compliance with EPA standards for ground water protection at inactive uranium mill tailings sites. These standards are contained in Subparts $A$ and $C$ of 40 CFR Part 192 (60 FR 2854) under Title I of the UMTRCA, as amended. This section summarizes the water resources protection strategy for the Slick Rock uranium mill tailings Burro Canyon disposal site and demonstrates compliance with the final EPA ground water standards (60 FR 2854). A detailed hydrogeologic characterization of ground water at the UC and NC processing sites and the Burro Canyon disposal site is presented in Attachment 3. The water resources protection strategy for the Burro Canyon disposal site is presented in Attachment 4.

To achieve compliance with the final EPA ground water protection standards in Subpart A of 40 CFR Part 192 (60 FR 2854), the DOE proposes to apply supplemental standards based on limited use ground water because of low yield (less than 150 gallons per day [gpd]) $\left(6.6 \times 10^{-3}\right.$ liters per second [L/s]) in the uppermost aquifer.

Ground water in lithologic units underlying the upper sandstone unit of the Burro Canyon Formation (uppermost aquifer) is protected from potential site-related contamination by hydrogeologic isolation. Low permeability mudstone units separate the three (upper, middle, and lower) sandstone units of the. Burro Canyon Formation, and upward vertical hydraulic gradients in the lower and middle sandstone units inhibit the downward migration of water. As a result, the proposed remedial action will ensure protection of human health and the environment.

\subsection{HYDROGEOLOGIC CHARACTERIZATION}

The DOE has characterized the hydrogeologic units, aquifer hydraulic and transport properties, tailings materials, geochemical conditions, and water use at the Slick Rock UC and NC processing sites and the Burro Canyon disposal site. Major points are discussed in the following subsections. Attachment 3 describes in detail the hydrologic site characterization efforts.

\subsubsection{Identification of hydrogeologic units}

\section{Processing site}

The uppermost aquifer at the NC and UC sites consists of three hydrostratigraphic units: the Quaternary alluvium associated with the Dolores River floodplain deposits, the Slick Rock and Dewey Bridge Members of the Entrada Formation, and the Navajo Sandstone. A plan map of the NC and UC sites is provided in Figure 5.1. Figure 5.2 provides a geologic cross section transecting both the UC and NC processing sites. Ground water flow is unconfined in the alluvium and is expected to be semiconfined to confined in the underlying Entrada Formation and the Navajo Sandstone. These three formations may be hydraulically connected on a localized basis, based on lithologic data and ground water levels. Ground water elevations in the 


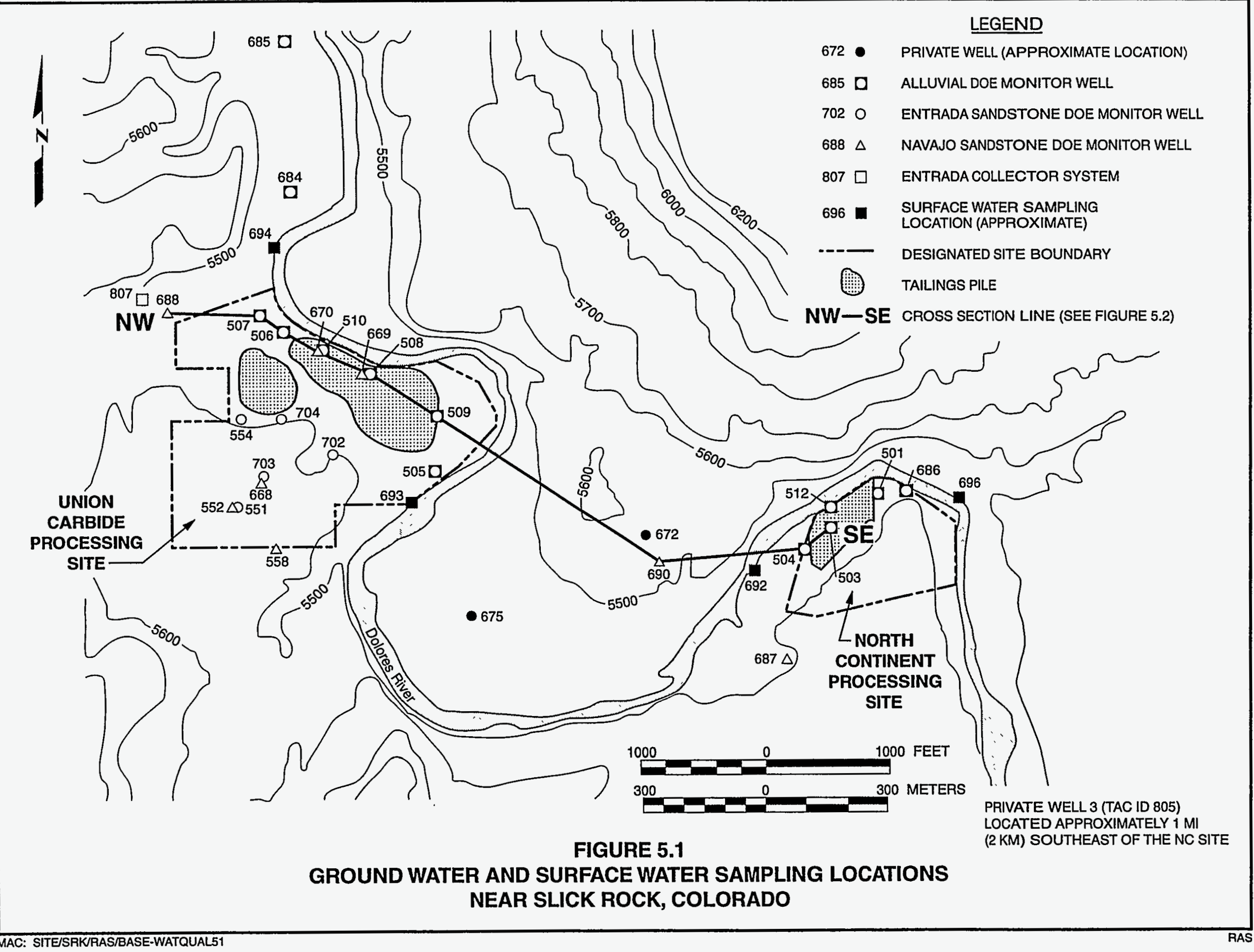




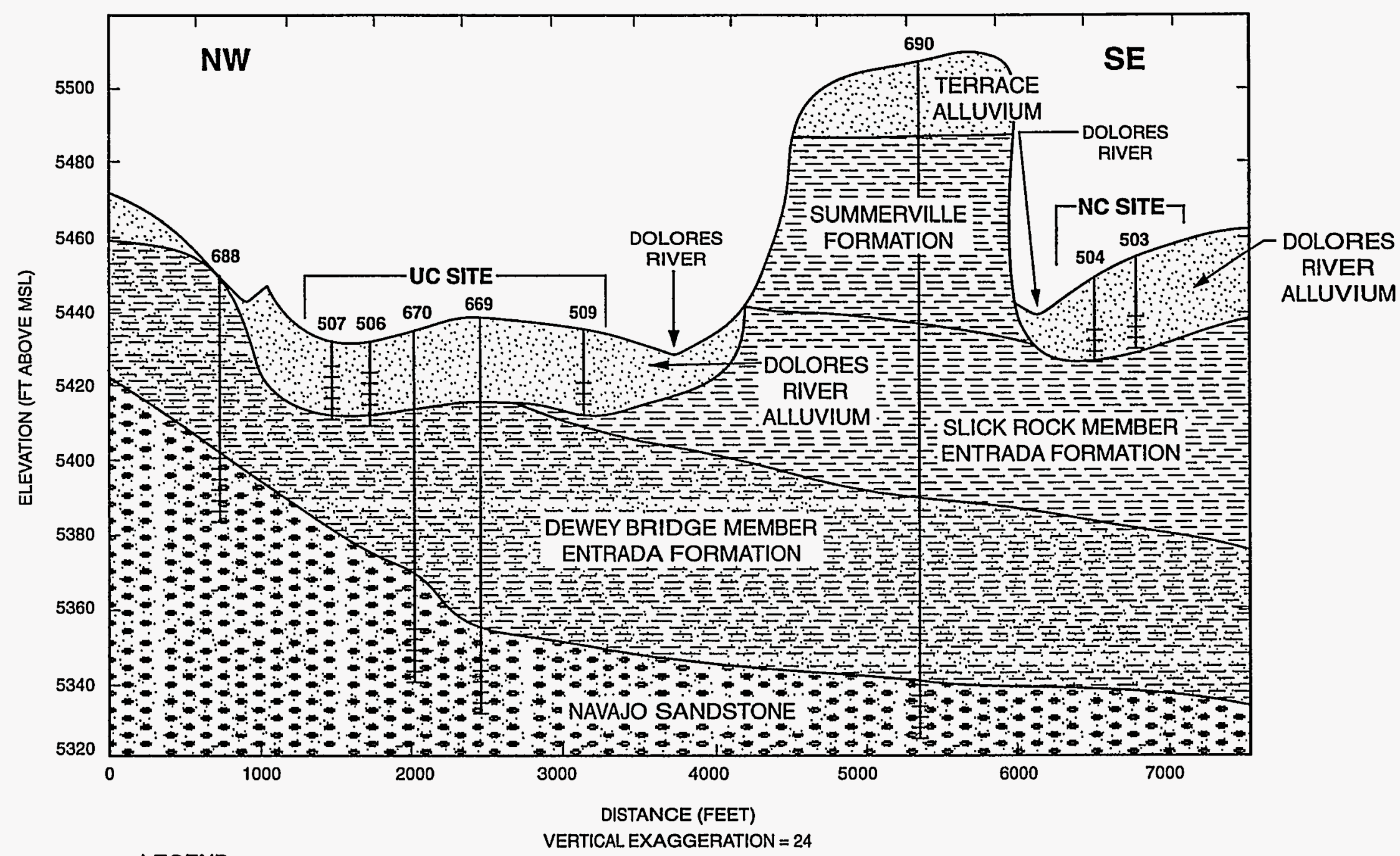

LEGEND

VERTICAL EXAGGERATION $=24$

MONITOR WELL
SCREENED INTERVAL

NOTE: SEE FIGURE 5.1 FOR CROSS SECTION LOCATION.

FIGURE 5.2

GEOLOGIC CROSS SECTION (NORTHWEST-SOUTHEAST)

NC AND UC SITES NEAR SLICK ROCK, COLORADO 
alluvium, Entrada Formation, and Navajo Sandstone remain relatively constant and do not show seasonal fluctuations.

The Dolores River alluvium is composed of unconsolidated clayey sands, sandy gravels, and cobbles from the ground surface to an approximate depth of $20 \mathrm{ft}$ $(6 \mathrm{~m})$ at both the UC and NC sites. Quaternary alluvium materials also cap the tops of terraces surrounding the Dolores River floodplain. However, the occurrence of ground water in the alluvium at the processing sites is limited to the recent channel and paleochannels of the Dolores River. The depth to ground water at both processing sites ranges from 5 to $20 \mathrm{ft}(2$ to $6 \mathrm{~m})$ in wells screened in the alluvium and is approximately the same as the surface water level of the Dolores River. Ground water flow in the alluvium is generally to the north.

The Jurassic Entrada Formation underlies the alluvium in the Dolores River floodplain and underlies the Summerville Formation in terraced areas adjacent to the floodplain (Figure 5.2). Two members of the Entrada Formation are present: the Slick Rock Member and the Dewey Bridge Member, which dip toward the northeast. The Slick Rock Member is composed of light brown fine-grained sand that is generally not well cemented and therefore erodes easily. The Dewey Bridge Member of the Entrada Formation underlies the Slick Rock Member at the NC processing site. At the UC site, where the Slick Rock Member is absent, the Dewey Bridge Member directly underlies Dolores River alluvium; it consists of reddish-brown clayey siltstone, viery fine-grained sandstone, and shale. The Dewey Bridge Member is more impermeable than the Slick Rock Member. The tops of the Dewey Bridge and Slick Rock Members of the Entrada Formation were encountered beneath the alluvial deposits to depths ranging from 1 to $88 \mathrm{ft}(0.3$ to $27 \mathrm{~m})$. Ground water movement appears to be to the east in the Entrada Formation, based on available water level data from monitor wells on the UC site. However, this representation may be biased by a limited number of monitor wells placed across a relatively small areal extent of the UC site.

The Navajo Sandstone underlies the Entrada Formation throughout the Slick Rock area at depths ranging from 53 to $173 \mathrm{ft}(16$ to $53 \mathrm{~m})$ below the surface. The Navajo Sandstone is composed of light-brown to reddish-brown, finegrained sandstone. The direction of ground water flow in the Navajo Sandstone is generally to the north at both processing sites. Variability in the directions of horizontal and vertical ground water flow is expected to be primarily a result of differences in subsurface material permeability. The static ground water elevations suggest that ground water in the Navajo Sandstone is semiconfined to confined, depending upon the permeability and thickness of the overlying hydrostratigraphic units. Because the bottom of the Navajo Sandstone was not encountered in any of the DOE borings, the thickness of the Navajo Sandstone has not been determined directly in the area of the Slick Rock processing sites. However, Shawe et al. (1968) report that the Navajo Sandstone ranges from 0 to $420 \mathrm{ft}(128 \mathrm{~m})$ thick in the Slick Rock area. 


\section{Disposal site}

A site plan with hydrogeologic testing locations at the Burro Canyon site is shown in Figure 5.3. Four hydrostratigraphic units, consisting of one unsaturated unit and three saturated units, underlie the Burro Canyon disposal site, as shown in the geologic cross section in Figure 5.4. The unsaturated hydrostratigraphic unit is the lowest unit of the Dakota Sandstone and the uppermost Burro Canyon claystones and mudstones. The three saturated sandstone units within the Burro Canyon Formation are at approximate depths of 100,200 , and $300 \mathrm{ft}(30,60$, and $90 \mathrm{~m})$ and are described.as the upper, middle, and lower units, respectively. These units are composed of fine- to medium-grained sandstone layers ranging from 25 to $75 \mathrm{ft}(7.6$ to $23 \mathrm{~m})$ thick. The sandstone layers are hydrogeologically separated from one another by interbedded mudstone and siltstone units approximately 50 to $65 \mathrm{ft}(15$ to $20 \mathrm{~m}$ ) thick.

The lowest unit of Dakota Sandstone consists primarily of low-permeability carbonaceous shale and mudstone. Two thin sandstone layers, approximately 1 to $6 \mathrm{ft}(0.3$ to $2 \mathrm{~m})$ thick, are interbedded with the shales and mudstones in the lower Dakota Sandstone.

The uppermost aquifer at the Burro Canyon disposal site is the upper sandstone unit of the Burro Canyon Formation. Ground water in this unit is unconfined and the yield is very low. The top of the upper sandstone unit is 50 to $100 \mathrm{ft}(20$ to $30 \mathrm{~m}$ ) below the surface. The depth to the water table ranges from 75 to $110 \mathrm{ft}(23$ to $34 \mathrm{~m})$. Measured ground water elevations have remained constant over time. The upper sandstone unit is not a current or potential source of drinking water because the quantity of water available is less than $150 \mathrm{gpd}\left(6.6 \times 10^{-3} \mathrm{~L} / \mathrm{s}\right)$, as evidenced by on-site aquifer performance tests. As a result, the ground water in the upper sandstone unit is limited use ground water, as defined in 40 CFR $\$ 192.11(e)$ of the final EPA ground water standards (60 FR 2854).

The middle sandstone unit is a confined aquifer approximately 55 to $75 \mathrm{ft}$ (17 to $23 \mathrm{~m}$ ) thick. It is overlain by approximately 60 to $70 \mathrm{ft}$ (about $20 \mathrm{~m}$ ) of laterally extensive mudstone. The top of the middle sandstone unit occurs between 140 and $191 \mathrm{ft}(42$ to $58.2 \mathrm{~m})$ below the surface in the vicinity of the disposal cell footprint. The potentiometric surface is approximately $40 \mathrm{ft}(12 \mathrm{~m})$ above the top of the middle sandstone unit, resulting in an upward hydraulic gradient.

The lower sandstone unit of the Burro Canyon Formation is $39 \mathrm{ft}(12 \mathrm{~m})$ thick beneath the disposal cell, and the top of the unit is approximately 250 to $300 \mathrm{ft}$ $(76$ to $91 \mathrm{~m})$ below the surface. Ground water in this unit is confined by the thick sequence of overlying low-permeability mudstones and siltstones of the Burro Canyon Formation and has an upward gradient with the potentiometric surface averaging $52 \mathrm{ft}(16 \mathrm{~m})$ above the middle sandstone unit. 


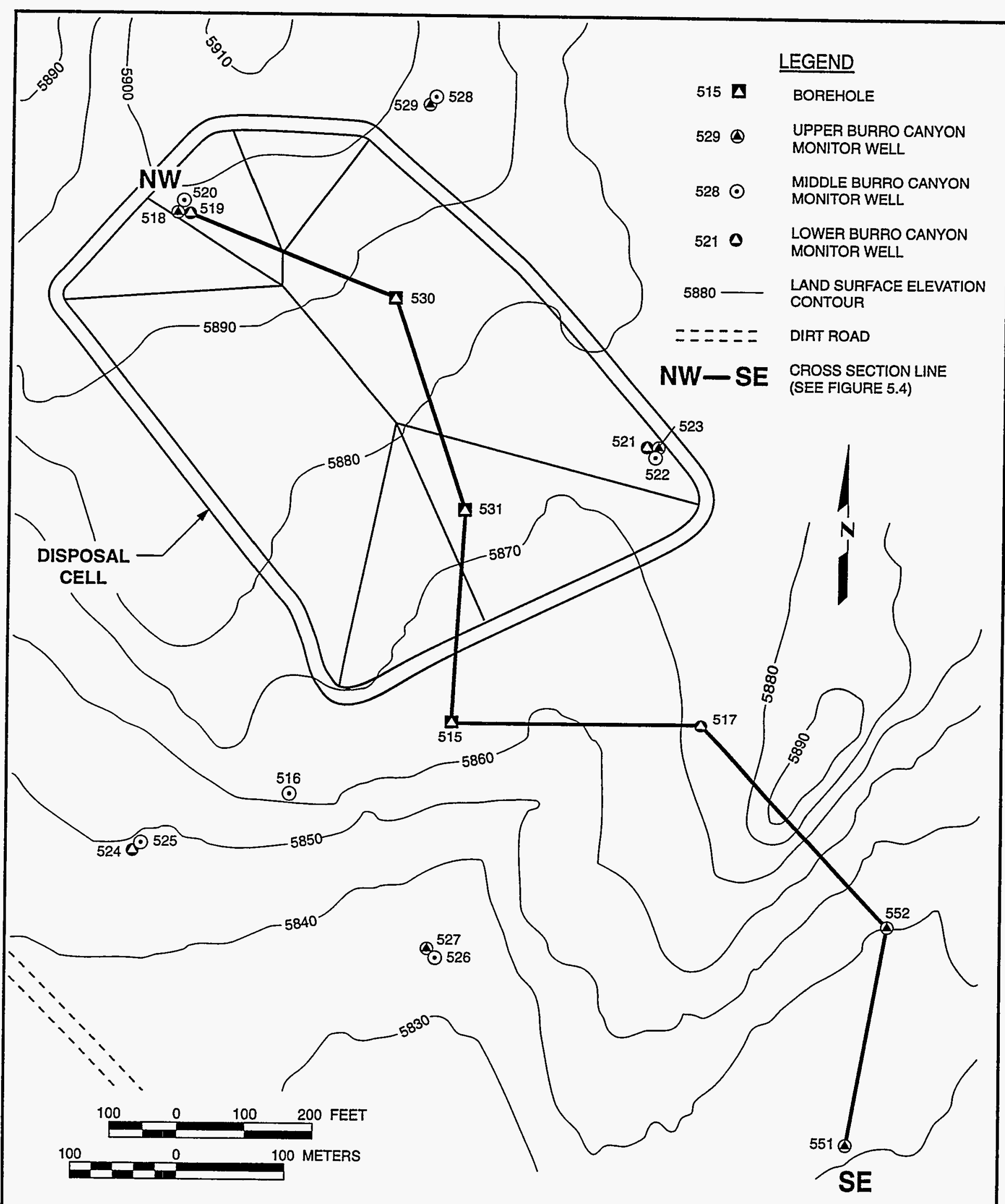

FIGURE 5.3

MONITOR WELL LOCATIONS

BURRO CANYON DISPOSAL SITE NEAR SLICK ROCK, COLORADO 


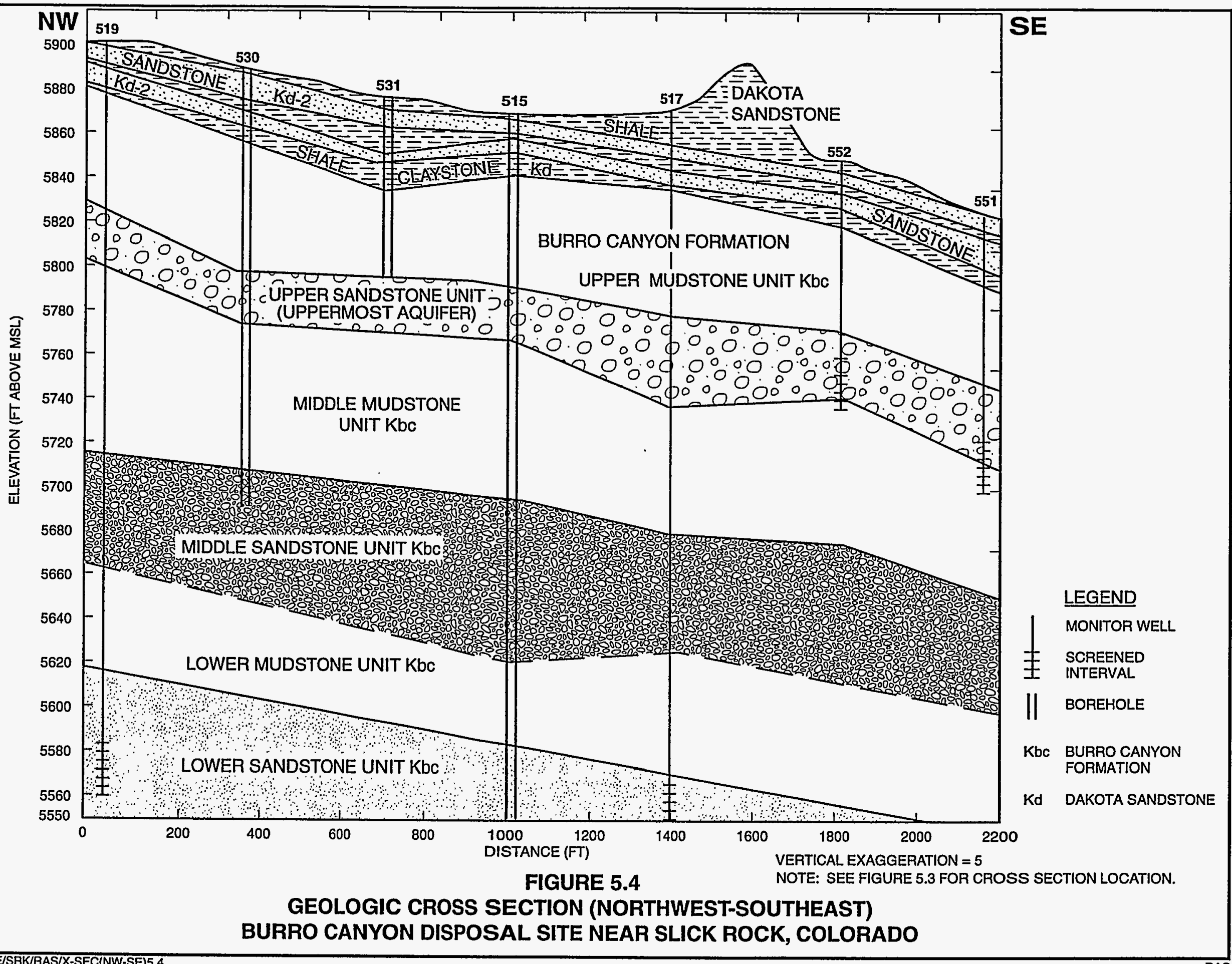


The source of recharge to the Burro Canyon Formation sandstone is approximately 0.25 to $0.75 \mathrm{mi}(0.40$ to $1.2 \mathrm{~km})$ northeast of the site. Sandstone beds outcrop along the east limb of the Disappointment syncline and intercept tributaries to the Nicholas Wash drainage system. Ground water then flows to the south-southeast and eventually dissipates (discharges) into the surrounding geologic strata south of the Burro Canyon disposal site.

\subsubsection{Hydraulic and transport properties}

\section{Processing sites}

Slug tests were conducted in the shallow alluvium and in the Navajo Sandstone at the NC and UC processing sites in 1986 and 1987. The middle hydrostratigraphic unit, the Entrada Formation, was not tested. Table.5.1 shows the hydraulic conductivities estimated for the Dolores River alluvium and the Navajo Sandstone at the Slick Rock, Colorado, processing sites.

Table 5.1 Average hydraulic properties at the Slick Rock, Colorado, processing sites

\begin{tabular}{lcc}
\hline \multicolumn{1}{c}{ Characteristic } & Dolores River alluvium & Navajo Sandstone \\
\hline $\begin{array}{l}\text { Average hydraulic conductivity } \\
\text { (UC) }\end{array}$ & $14 \mathrm{ft} / \mathrm{day}$ & $2.4 \times 10^{-2} \mathrm{ft} /$ day \\
Average hydraulic conductivity & $23 \mathrm{ft} / \mathrm{day}$ & $\left(8.5 \times 10^{-6} \mathrm{~cm} / \mathrm{s}\right)$ \\
(NC) & $\left(8.1 \times 10^{-3} \mathrm{~cm} / \mathrm{s}\right)$ & Not determined \\
$\begin{array}{l}\text { Average linear ground water } \\
\text { velocity (UC) }\end{array}$ & $160 \mathrm{ft} / \mathrm{yr}$ & $1 \mathrm{ft} / \mathrm{yr}\left(1 \times 10^{-6} \mathrm{~cm} / \mathrm{s}\right)$ \\
$\begin{array}{l}\text { Average linear ground water } \\
\text { velocity (NC) }\end{array}$ & $\left(1.5 \times 10^{-4} \mathrm{~cm} / \mathrm{s}\right)$ & Not determined \\
\hline
\end{tabular}

The average linear ground water velocity in the alluvium at the NC site was estimated to be $100 \mathrm{ft}$ per $\mathrm{yr}(\mathrm{ft} / \mathrm{yr})\left(1 \times 10^{-4} \mathrm{~cm} / \mathrm{s}\right)$, based on an average hydraulic conductivity of $23 \mathrm{ft} /$ day $\left(8.1 \times 10^{-3} \mathrm{~cm} / \mathrm{s}\right)$, a hydraulic gradient of 0.003 , and an effective porosity of 0.25 for sand and gravel (Freeze and Cherry, 1979). The average linear ground water velocity in the alluvium at the UC site is estimated to be $160 \mathrm{ft} / \mathrm{yr}\left(1.5 \times 10^{-4} \mathrm{~cm} / \mathrm{s}\right)$, based on an average hydraulic conductivity of $14 \mathrm{ft} /$ day $\left(4.9 \times 10^{-3} \mathrm{~cm} / \mathrm{s}\right)$, a hydraulic gradient of 0.008 , and an effective porosity of 0.25 . The Dolores River alluvium is recharged by seepage from the Dolores River upstream and by precipitation. Ground water discharges from the alluvium into the Dolores River downgradient.

The average linear ground water velocity of the Navajo Sandstone is considerably lower than that of the alluvium. The calculated average linear ground water velocity in the Navajo Sandstone is $1 \mathrm{ft} / \mathrm{yr}\left(1 \times 10^{-6} \mathrm{~cm} / \mathrm{s}\right)$, based on an average hydraulic conductivity of $2.4 \times 10^{-2} \mathrm{ft} /$ day $\left(8.5 \times 10^{-6} \mathrm{~cm} / \mathrm{s}\right)$ 
under a hydraulic gradient of 0.02 and an estimated effective porosity of 0.30 (Cooley et al., 1969). The Navajo Sandstone is expected to be recharged by seepage from the Dolores River and overlying stratigraphic units when ground water movement is semiconfined. Ground water discharges into surrounding stratigraphic units.

\section{Disposal site}

Table 5.2 presents average aquifer parameters and average linear ground water velocities for the Dakota Sandstone and the Burro Canyon Formation. The hydraulic conductivities of the unsaturated Dakota Sandstone bedrock and the unsaturated Burro Canyon mudstones were determined by field packer tests. The average horizontal hydraulic conductivity of the lower Dakota Sandstone was $4 \times 10^{-1} \mathrm{ft} / \mathrm{day}\left(1 \times 10^{-4} \mathrm{~cm} / \mathrm{s}\right)$, and the average horizontal hydraulic conductivity of the Burro Canyon mudstones was $6 \times 10^{-3} \mathrm{ft} / \mathrm{day}\left(2 \times 10^{-6}\right.$ $\mathrm{cm} / \mathrm{s}$ ). Packer tests indicate that the saturated horizontal hydraulic conductivity of the Dakota Sandstone is moderate and is several orders of magnitude greater than the Burro Canyon mudstone. The hydraulic conductivity decreases with depth in the Burro Canyon mudstone, reflecting decreased fracture permeability with depth.

Table 5.2 Average hydraulic properties at the Slick Rock, Colorado, disposal site

\begin{tabular}{|c|c|c|c|c|c|}
\hline \multirow[b]{2}{*}{ Characteristic } & \multirow{2}{*}{$\begin{array}{l}\text { Dakota } \\
\text { Sandstone }\end{array}$} & \multirow{2}{*}{$\begin{array}{l}\text { Burro Canyon } \\
\text { mudstone }\end{array}$} & \multicolumn{3}{|c|}{ Burro Canyon Formation Sandstone unit } \\
\hline & & & Upper & Middle & Lower \\
\hline $\begin{array}{l}\text { Hydraulic } \\
\text { conductivity }\end{array}$ & $\begin{array}{l}4 \times 10^{-1} \mathrm{ft} / \mathrm{day} \\
\left(1 \times 10^{-4} \mathrm{~cm} / \mathrm{s}\right)\end{array}$ & $\begin{array}{l}6 \times 10^{-3} \mathrm{ft} / \text { day } \\
\left(2 \times 10^{-6} \mathrm{~cm} / \mathrm{s}\right)\end{array}$ & $\begin{array}{l}4 \times 10^{-2} \mathrm{ft} / \mathrm{day} \\
\left(1 \times 10^{-5} \mathrm{~cm} / \mathrm{s}\right)\end{array}$ & $\begin{array}{l}9 \times 10^{-2} \mathrm{ft} / \mathrm{day} \\
\left(3 \times 10^{-5} \mathrm{~cm} / \mathrm{s}\right)\end{array}$ & $\begin{array}{c}5 \times 10^{-3} \mathrm{ft} / \text { day } \\
\left(2 \times 10^{-6}\right. \\
\mathrm{cm} / \mathrm{s})\end{array}$ \\
\hline $\begin{array}{l}\text { Average linear } \\
\text { ground water } \\
\text { velocity }\end{array}$ & NA & NA & $\begin{array}{c}6 \mathrm{ft} / \mathrm{yr} \\
\left(6 \times 10^{-6} \mathrm{~cm} / \mathrm{s}\right)\end{array}$ & $\begin{array}{c}2 \mathrm{ft} / \mathrm{yr} \\
\left(2 \times 10^{-6} \mathrm{~cm} / \mathrm{s}\right)\end{array}$ & $\begin{array}{c}1 \mathrm{ft} / \mathrm{yr} \\
\left(1 \times 10^{-6}\right. \\
\mathrm{cm} / \mathrm{s})\end{array}$ \\
\hline
\end{tabular}

NA - not applicable.

The average linear ground water velocity in the Burro Canyon upper sandstone unit was estimated to be $6 \mathrm{ft} / \mathrm{yr}\left(6 \times 10^{-6} \mathrm{~cm} / \mathrm{s}\right)$, based on an average hydraulic conductivity of $4 \times 10^{-2} \mathrm{ft} /$ day $\left(1 \times 10^{-5} \mathrm{~cm} / \mathrm{s}\right)$, a hydraulic gradient of 0.04 , and an effective porosity of 0.10 . The average saturated thickness of the upper sandstone unit (uppermost aquifer) is $12 \mathrm{ft}(4 \mathrm{~m})$. Ground water flows southeast along the axis of the Disappointment syncline.

The average linear ground water velocity of the Burro Canyon middle sandstone unit is $2 \mathrm{ft} / \mathrm{yr}\left(2 \times 10^{-6} \mathrm{~cm} / \mathrm{s}\right)$, assuming an average hydraulic conductivity of $9 \times 10^{-2} \mathrm{ft} /$ day $\left(3 \times 10^{-5} \mathrm{~cm} / \mathrm{s}\right)$, a hydraulic gradient of 0.02 , and an effective porosity of 0.2 . The confined conditions in this unit create a substantial upward 
hydraulic potential. The potentiometric surface of the middle unit averages $42 \mathrm{ft}(13 \mathrm{~m})$ above the top of the sandstone unit. This potentiometric surface, however, is not higher in elevation than the overlying potentiometric surface measured in monitor wells screened in the upper sandstone unit. The direction of ground water flow is to the southeast. Recharge to the middle sandstone unit occurs upgradient from the disposal cell, approximately 0.25 to $0.75 \mathrm{mi}$ $(0.40$ to $1.2 \mathrm{~km})$ northeast of the site. Sandstone beds outcrop along the east limb of the Disappointment syncline and intercept tributaries to the Nicholas Wash drainage system. Ground water then flows to the south-southeast and eventually dissipates (discharges) into the surrounding geologic strata south of the Burro Canyon disposal site.

The average linear ground water velocity in the Burro Canyon lower sandstone unit is $1 \mathrm{ft} / \mathrm{yr}\left(1 \times 10^{-6} \mathrm{~cm} / \mathrm{s}\right)$, assuming a hydraulic conductivity of $5 \times$ $10^{-3} \mathrm{ft} /$ day $\left(2 \times 10^{-6} \mathrm{~cm} / \mathrm{s}\right)$, a gradient of 0.06 , and an effective porosity of 0.1 . Ground water in this unit is confined by the thick sequence of overlying lowpermeability mudstones and siltstones of the Burro Canyon Formation. Ground water has an upward gradient, with the potentiometric surface 169 to $240 \mathrm{ft}$ $(51.5$ to $73 \mathrm{~m})$ above the top of the lower sandstone unit and averaging $52 \mathrm{ft}$ $(16 \mathrm{~m})$ above the middle sandstone unit. The lower sandstone unit has an extremely low velocity and well yield. Vertical recharge to and discharge from the lower sandstone unit is restricted because the low-permeability interbedded claystone and siltstone strata impede infiltration.

\subsubsection{Geochemical conditions}

\section{Processing site}

Background ground water quality is defined as the quality of ground water expected at the site if uranium processing had not occurred. Background ground water quality is characterized as follows for each of the three hydrostratigraphic units:

Dolores River alluvium. Background ground water quality in the alluvial materials is characterized as a calcium sodium sulfate type at both the NC and UC sites. Total dissolved solids (TDS) concentrations measured in alluvial background monitor wells range from 622 to 1180 milligrams per liter (mg/L), and average $800 \mathrm{mg} / \mathrm{L}$ at the NC site and $963 \mathrm{mg} / \mathrm{L}$ at the UC site. The background $\mathrm{pH}$ ranges from 6.9 to 7.7. Concentrations or activities of chromium, molybdenum, uranium, and radium-226 and -228 exceeded the maximum concentration limits (MCLs) in one or more background alluvial monitor wells.

Entrada Formation. Background ground water quality of the Entrada Formation is characterized as a calcium-bicarbonate to sodium-bicarbonate type. The pH of ground water in the Entrada Formation at the UC site is slightly above neutral, ranging from 7.8 to 8.0. TDS concentrations measured in the Entrada background monitor wells range from 147 to $1990 \mathrm{mg} / \mathrm{L}$. Selenium and 
radium-226 and -228 exceeded their respective MCLs in ground water samples collected from the background monitor wells screened in the Entrada Formation. No monitor wells are screened in the Entrada Formation at the NC site.

Navajo Sandstone. Background ground water quality in the Navajo Sandstone is characterized as a sodium-bicarbonate type at the NC site and a magnesiumbicarbonate type at the UC site. The $\mathrm{pH}$ of ground water measured in background NC and UC monitor wells screened in the Navajo Sandstone ranges from 7.2 to 8.2. TDS concentrations are generally lower at the UC site (ranging from 229 to $1160 \mathrm{mg} / \mathrm{L}$ ) than at the NC site (ranging from 492 to $1530 \mathrm{mg} / \mathrm{L}$ ). The MCLs for chromium, molybdenum, radium-226 and -228 , selenium, silver, and uranium were equaled or exceeded on one or more occasions in Navajo Sandstone background monitor well samples.

\section{Tailings}

The NC tailings site consists of the tailings pile and windblown contaminated areas, covering approximately 12 ac (4.9 ha). The tailings primarily consist of sandy gravel, sand, and silty sand. At the UC site, the tailings pile and surrounding contaminated land cover 55 ac (22 ha). The tailings consist of mostly fine- to medium-grained sand with some clayey sand and silt. The tailings material is finer-grained at the UC site than at the NC site. Seepage from the tailings has contaminated the ground water in the alluvium beneath both the NC and UC sites.

The chemical characteristics of the NC and UC tailings materials were evaluated by pore fluid sampling with suction lysimeters. The $\mathrm{pH}$ of the tailings pore fluid is near-neutral, ranging from 6.2 to 7.8. The TDS concentrations range from 2430 to $33,900 \mathrm{mg} / \mathrm{L}$. Average concentrations of arsenic, cadmium, molybdenum, selenium, and uranium exceeded the MCLs in lysimeter samples collected from the NC site. At the UC site, the average pore fluid concentrations of cadmium, molybdenum, nitrate, selenium, and uranium exceeded the MCLs.

On-site and downgradient (baseline) water quality has been compared to that of background ground water. Average TDS concentrations in baseline alluvial ground water (ranging from $2393 \mathrm{mg} / \mathrm{L}$ at the NC site to $3059 \mathrm{mg} / \mathrm{L}$ at the UC site) are approximately 3 times those of background. The primary regulated hazardous constituents of concern in the Dolores River alluvium are molybdenum, nitrate, selenium, and uranium at the UC processing site and selenium and uranium at the NC processing site. The baseline water quality of the Entrada Formation also appears to be affected by uranium processing activities; the average TDS concentrations in baseline Entrada monitor wells $(1070 \mathrm{mg} / \mathrm{L})$ are approximately 3 times those observed in background Entrada monitor wells $(303 \mathrm{mg} / \mathrm{L})$ and concentrations of selenium exceed the $\mathrm{MCL}$ and background. Baseline water quality in the Navajo Sandstone does not appear to be affected by processing activities. TDS, $\mathrm{pH}$, and the regulated constituents show minimal variation between background and baseline water quality. 


\section{Disposal site}

Ground water quality data were characterized individually for each sandstone unit in the Burro Canyon Formation because the units are hydrogeologically separated from one another. Ground waters in the upper and middle Burro Canyon Formation sandstone units have been classified as sulfate-sodiumbicarbonate. Ground water in the lower Burro Canyon Formation sandstone unit is sodium-bicarbonate. Ground water $\mathrm{pH}$ is near-neutral to slightly above neutral, ranging from 7.2 to 9.1 in the upper sandstone unit, 7.2 to 7.6 in the middle sandstone unit, and 8.6 to 9.6 in the lower sandstone unit. TDS concentrations tend to decrease with depth, ranging from 556 to $973 \mathrm{mg} / \mathrm{L}$ in the upper sandstone unit, 422 to $696 \mathrm{mg} / \mathrm{L}$ in the middle sandstone unit, and 256 to $485 \mathrm{mg} / \mathrm{L}$ in the lower sandstone unit.

Naturally occurring selenium and radium-226 and -228 have equaled or exceeded the EPA MCLs in monitor wells screened in the upper sandstone unit. In addition, the EPA MCL for radium-226 and -228 was exceeded slightly in one monitor well screened in the middle-sandstone unit, in a one-time occurrence.

\subsubsection{Characterization methods}

The DOE characterized the hydrogeologic setting of the processing and disposal sites by installing monitor wells, collecting water level data from these monitor wells, and performing hydraulic testing of the properties, tailings source-term characterization through pore water analyses, and periodic ground water quality analyses from select monitor wells. These site characterization activities provide sufficient information to design and implement a surface remediation plan for relocating the RRM to the Burro Canyon disposal site. Attachment 3 provides details of these characterization efforts. The characterization programs conducted by DOE followed procedures outlined in the standard operating procedures for the UMTRA Project (JEG, n.d.) and the TAD (DOE, 1989).

Ground water quality was characterized by analyzing constituents listed in Table 8.1 of the TAD (DOE, 1989). The standard operating procedures for the UMTRA Project (JEG, n.d.) outline procedures for sampling, preserving, storing, and analyzing samples and include $\mathrm{OA}$ and $\mathrm{QC}$ protocols.

Attachment 3 provides a statistical treatment of ground water quality in the uppermost aquifer at both the processing and disposal sites. The statistical analyses include the minimum, mean, median, maximum, percentage of nondetects, and the 98-percent confidence interval for background, on-site, and downgradient ground water quality. Ground water quality can be characterized by describing an average concentration and a statistical maximum. The procedures for calculating average and statistical maximum concentrations are discussed in the Statistical Analysis of Ground-Water Monitoring Data at RCRA Facilities-Interim Final Guidance (EPA, 1989) and are described in the TAD. Average concentrations of hazardous constituents are represented statistically by a mean or median, depending on the proportion of nondetects, the 
distribution of the water quality data, and the number of samples available. The following guidelines apply:

- If the coefficient of variation of the data is greater than 1, the distribution is assumed to be lognormal and the geometric mean is reported.

- If the coefficient of variation of the data is less than 1 , the distribution is assumed to be normal and the arithmetic mean is reported.

- If more than 15 percent of the data are below detection, the median is reported.

- If fewer than four samples are available, the median is reported. Distribution types are unknown if fewer than four samples are reported.

The statistical maximum is the upper limit of the 98-percent confidence interval for the true average concentration assuming normal or lognormal distributions. A nonparametric upper confidence interval is used if more than 15 percent of the data are below detection. If fewer than four samples are reported, the maximum observed concentration is chosen as a statistical maximum. When most of the data are below detection, the reported statistical maximum may be the detection limit divided by two, as computed by the UMTRA Project Software Program for Environmental Analysis and Reporting (SPEAR) system (DOE, 1992a). When the statistical values calculated are below the actual laboratory detection limits, the laboratory detection limits reported in Table 8.1 of the TAD (DOE, 1989) are applied.

\section{Processing sites}

Site-specific studies that addressed ground water at the Slick Rock NC and UC processing sites were initiated in 1981. Ford, Bacon \& Davis Utah Inc.

(FBDU, 1981) conducted an engineering assessment. The DOE initiated a reconnaissance investigation of the Slick Rock NC and UC sites in November 1984. Initial hydrogeologic characterization efforts at the processing sites continued through 1986. These investigations included the installation of six shallow monitor wells in the Dolores River alluvium, four deep monitor wells in the Navajo Sandstone, nine auger borings to the top of bedrock, and three test pits. From this limited hydrogeological characterization, it appeared that the Navajo Sandstone was confined by the Entrada Formation and an upward potentiometric gradient existed from the Navajo Sandstone into the Entrada Formation.

Additional site characterization at the UC site continued during 1987. Related field activities included excavating 22 test pits, conducting surface geophysical testing, drilling 10 borings, and packer testing 2 boreholes in the Entrada Formation. The DOE drilled one borehole and installed three monitor wells in the Entrada Formation in 1989. Near-surface ground water was encountered in these monitor wells. Additional drilling in the Entrada indicated the presence of 
buried paleochannels incised by the ancestral Dolores River. In August 1989, the DOE completed a seismic refraction survey across the UC processing site. In addition, the data produced from some of these field activities suggested that the Entrada Formation may not be laterally extensive across the site and may not completely separate the Dolores River alluvium from the Navajo Sandstone, as was previously thought.

To more accurately define these subsurface features, the DOE initiated a final site characterization drilling program. Monitor wells $(10)$ and exploratory boreholes (12) were installed in September 1989. This program identified 1) the locations, dimensions, and gradients of paleochannels; 2) numerous terraces associated with the incision of the Dolores River; 3 ) the presence of nearsurface ground water in the Entrada Formation and the Navajo Sandstone across parts of the UC processing site; and 4) the susceptibility of the Navajo Sandstone aquifer to contamination, due to localized erosion of the Entrada Formation confining beds. As a result, it was concluded that the Entrada Formation may not be a laterally extensive confining unit as was originally thought. Additional information regarding ground water occurrence and hydraulic properties is provided in Sections 3.1.3 and 3.1.4 of Attachment 3. Tables 3.1 and 3.2 of Appendix A of Attachment 3 provide monitor well construction information for the NC and UC processing sites, respectively. Appendix $B$ of Attachment 3 provides lithologic logs and construction information for all DOE monitor wells.

Ground water elevations were measured and water table maps were constructed to determine the direction of ground water flow and hydraulic gradients. Slug tests were performed in the shallow alluvial material and in the Navajo Sandstone to estimate hydraulic conductivity. Sediment, tailings, surface water, ground water, and lysimeter pore fluid samples were collected at the NC and UC processing sites and analyzed to characterize existing conditions. Lysimeter pore fluid samples were analyzed to characterize the tailings source term. Ground water samples have been used to establish the nature and estimate the extent of contamination caused by uranium processing activities. The frequency and duration of sample collection is a function of when the monitor wells were installed, their proximity to the processing sites, and water quality data.

\section{Disposal site}

Three site-specific hydrologic investigations have been conducted in the vicinity of the Burro Canyon disposal site. In 1985, preliminary testing was conducted southeast of the current Burro Canyon disposal site location. Eight test pits and three boreholes were excavated to determine whether the location was suitable as a relocated disposal site. The area was found to be suitable for tailings disposal, as reported in the Comparative Analysis of Disposal Site Alternatives Report for the UMTRA Project Slick Rock Sites Located at Slick Rock, Colorado (DOE, 1986). 
A second detailed site investigation was conducted during 1990 and 1991 at the current Burro Canyon disposal site. During 1990, the DOE installed 14 monitor wells, 4 boreholes, and 13 test pits to characterize lithology, ground water elevations and hydraulic gradients, aquifer properties, and ground water quality at the disposal site.

Additional testing was conducted in 1991 in response to two issues raised by Colorado Department of Health (now the Colorado Department of Public Health and Environment): 1) the extent of the mudstone aquitard between the upper and middle sandstone units of the Burro Canyon Formation southeast (downgradient) of the Burro Canyon disposal site, and 2) the degree of downgradient saturation in the upper sandstone unit. An exploration core hole was drilled approximately $900 \mathrm{ft}(300 \mathrm{~m})$ from the edge of the disposal cell to a total depth of $179 \mathrm{ft}(54.6 \mathrm{~m})$ below the surface. The exploration core hole confirmed that the Burro Canyon mudstone and sandstone units were continuous. A monitor well placed approximately $10 \mathrm{ft}(3 \mathrm{~m})$ north of the exploration core hole was completed to the base of the upper Burro Canyon Formation sandstone unit for a total depth of $113 \mathrm{ft}(34.4 \mathrm{~m})$. A second monitor well, placed approximately $650 \mathrm{ft}(200 \mathrm{~m})$ southeast of the edge of the Burro Canyon disposal cell, was drilled through the upper sandstone unit (from 72 to $101 \mathrm{ft}$ (22 to $30.8 \mathrm{ml}$ ) and the mudstone aquitard (from 101 to $169 \mathrm{ft}$ [30.8 to $51.5 \mathrm{~m}]$ ) and $10 \mathrm{ft}(3 \mathrm{~m})$ into the middle sandstone unit for a total depth of $179 \mathrm{ft}(54 \mathrm{~m})$. This well was then backfilled with bentonite and a screen was installed at the base of the upper sandstone unit from 80 to $100 \mathrm{ft}$ $(20$ to $30 \mathrm{~m})$, with filter pack material from 65 to $102 \mathrm{ft}(20$ to $31.1 \mathrm{~m})$. Geophysical logs (natural gamma, gamma-gamma, neutron, and resistivity) were run in the exploratory borehole and five DOE monitor wells.

Table 3.42, Appendix A of Attachment 3, presents monitor well information. Appendix B of Attachment 3 provides the lithologic logs and monitor well construction information:

The chemical and mineralogical properties of Burro Canyon sediment samples were characterized in 1990 by Pittsburgh Mineral \& Environmental Technology, Inc. (PMET, 1990). Sediment samples were collected from the Dakota Sandstone (sandstones and shales) and from Burro Canyon Formation (mudstones and sandstones). The laboratory work included chemical analyses, polarized light microscopy with modal analyses, chemical analyses, and $X$-ray diffraction analyses.

Relatively undisturbed samples were recovered for visual inspection and laboratory tests to determine unsaturated hydraulic conductivity, porosity, and other selected parameters. Five sediment samples were collected from sandstones and shales of the Dakota Sandstone and mudstones and sandstones of the Burro Canyon Formation. Laboratory analyses were conducted to determine moisture contents, bulk densities, porosities, saturated hydraulic conductivities, soil moisture retention curves, and particle densities (Daniel B. Stephens \& Associates, Inc., 1991). 
Ground water elevations were measured to map the potentiometric surface to determine the direction of ground water flow and hydraulic gradients. Bailer recovery tests, aquifer performance tests, and slug injection tests were conducted to determine hydraulic parameters of the upper, middle, and lower Burro Canyon Formation sandstone units. Water quality samples collected from selected wells in the Burro Canyon Formation sandstone units established background water quality at the disposal site.

\subsubsection{Water use}

\section{Processing site}

No municipal water supply wells exist at or in the vicinity of Slick Rock, Colorado. The community of Slick Rock consists of a combination restaurant/ general store. About 10 people, including residents of two trailers in the vicinity of the community, live within $10 \mathrm{mi}(16 \mathrm{~km})$ of the UC and NC processing sites.

A well survey conducted in February 1994 indicated 18 private wells currently or historically exist within a $2-\mathrm{mi}(3-\mathrm{km})$ radius of the Slick Rock UC and NC processing sites. Fourteen of these wells are registered with the Colorado Division of Water Resources, and the remaining four are nonregistered. Detailed information regarding private well locations, well permits, sampling dates, well construction, ground water units of completion, well status, and water use is provided in Table 3.41 of Appendix A to Attachment 3. Well permit information indicates that the nearby private wells are screened in the alluvium, and Entrada Formation and Navajo Sandstone. The 1994 well survey and follow-up water sampling of private wells indicated that of the 18 private wells, 2 are actively used, 11 existing wells are presumed to be inactive, 3 wells adjacent to the site that could not be located in the field are presumed to be sealed, and the status of 2 registered wells approximately $2 \mathrm{mi}(3 \mathrm{~km})$ east (upgradient of the processing sites) is unknown because of limited roadway access. Three private wells are downgradient of the UC site and are expected to be beyond the reach of the contaminant plume, as evidenced by the water quality in downgradient alluvial DOE monitor wells. The remainder of the wells are upgradient or crossgradient of the UC site. Of the two active wells, one is crossgradient and on the other side of the Dolores River from the NC and UC sites. Water quality monitoring conducted in February 1994 indicates that the water quality in this private well has not been affected by uranium processing activities. A ground water flow boundary appears to follow the course of the Dolores River and is expected to hydrologically separate these three wells from the NC tailings, which are on the opposite side of the Dolores River from the private wells. The other active well is upgradient of both sites.

In addition to the 18 private wells, a collector system that taps the Entrada Formation is located along a cliff face approximately $1500 \mathrm{ft}(450 \mathrm{~m})$ west (upgradient) of the UC site. This collector system appears to be in good condition and is believed to be used for livestock. 
Staff from the Bureau of Land Management and U.S. Geological Survey reported in February 1994 that they were unaware of any additional ground water users within $2 \mathrm{mi}(3 \mathrm{~km})$ of the UC and NC processing sites.

Surface water from the Dolores River is another potential source of water in the processing site vicinity. The Dolores River will be the construction water source used during remedial action construction. Rights to the surface water will be secured prior to surface remedial action construction.

\section{Disposal site}

No known registered or private wells are actively used within the upper sandstone unit of the Burro Canyon Formation within a $2-\mathrm{mi}(3-\mathrm{km})$ radius of the Burro Canyon disposal site.

Ground water development in the vicinity of the disposal site should not increase over the next 50 years, because not enough water is available to support development on any time scale. The first saturated hydrostratigraphic unit, the upper sandstone unit, has a low yield lless than 150 gpd $16.6 \times 10^{-3}$ $\mathrm{L} / \mathrm{s}])$, and therefore is classified as limited use in accordance with $40 \mathrm{CFR}$ $\$ 192.11(\mathrm{e})$ of the EPA ground water protection standards (60 FR 2854). By definition, limited use ground water is not a current or potential source of drinking water.

\subsection{CONCEPTUAL DESIGN FEATURES FOR WATER RESOURCES PROTECTION}

This section summarizes the principal design features of the Burro Canyon disposal site. Section 3.3 describes in detail the design features of the Burro Canyon disposal cell. The design features will ensure compliance and do not rely on active maintenance to ensure adequate long-term performance. Additional details and specifications of the conceptual design are provided in Attachment 1.

The disposal cell will hold approximately $621,000 \mathrm{yd}^{3}\left(475,000 \mathrm{~m}^{3}\right)$ of contaminated material and cover an area approximately $610 \mathrm{ft}(190 \mathrm{~m})$ wide and $900 \mathrm{ft}(280 \mathrm{~m})$ long along the southwest face of the mesa. The height of the cell will range from 30 to $50 \mathrm{ft}(9$ to $15 \mathrm{~m})$ above the existing ground surface. The completed disposal cell will occupy an area of 12 ac ( 4.9 ha). A buffer area of $32 \mathrm{ac}$ (13 ha) will bring the total area to $44 \mathrm{ac}$ (18 ha). The DOE will schedule long-term surveillance of the disposal area.

The disposal cell cover will have a rock riprap surface layer and additional components below the rock. A detailed schematic of the cover is shown in Attachment 1, Drawing Nos. SRK-DS-10-0335 and SRK-DS-10-0336.

The design for the disposal embankment cover consists of the following layers, in descending order: 
- Erosion protection layer. A layer of riprap (8 to 12 inches [200 to $300 \mathrm{~mm}$ ) will prevent erosion of the disposal cell by surface water runoff.

- Bedding layer. A 6-inch (150-mm)-thick sand/gravel bedding layer will prevent displacement of large diameter rock, protect the underlying frostprotection layer from erosion, and drain water laterally.

- Frost-protection laver. A 2-ft $(0.61$-m)-thick frost-protection layer, consisting of fine-grained soil with some sand, will protect the radon/infiltration barrier from the effects of freezing and thawing.

- Radon barrier layer. A $1.5-\mathrm{ft}(0.45-\mathrm{m})$-thick sandy clay radon barrier will inhibit radon emanation and reduce infiltration through the underlying contaminated material.

The material properties and available quantities for the cover materials have been adequately defined to conform with the applicable provisions of the SRP. In addition, the performance of the cover system has been evaluated using both state-of-the-art techniques and standard engineering methods. The results indicate the cover will remain effective for a period of time that is in compliance with the EPA standard for long-term performance (40 CFR \$192.02).

Natural, stable materials have been proposed for use in constructing the Burro Canyon disposal cell to ensure long-term performance. Materials for the rock erosion protection layer have been selected, based on durability, suitability, and size, to perform adequately over the design life of the disposal cell. The compacted radon barrier material will be protected from erosion by the overlying cover components.

The final EPA standards in Subparts A and C of 40 CFR Part 192 (60 FR 2854) require information and assessments to demonstrate that the disposal of RRM complies with ground water protection and performance standards. The required information and assessments can be categorized as follows: the ground water protection standard (see Section 5.3.1); a performance assessment and a closure performance standard (see Section 5.4); and a monitoring and corrective action program (see Section 5.5). The purpose of the ground water protection and performance standards is to establish the minimum acceptable performance of the disposal and control of RRM to prevent or control future releases of hazardous constituents. The performance assessment confirms the adequacy of the disposal cell and provides corrective action that may be necessary if the disposal cell does not perform adequately (NRC, 1989). The following sections describe in detail the four components of the ground water protection and performance standards. 


\subsubsection{Ground water protection standard for disposal}

The Burro Canyon disposal cell is designed to control radioactive materials and nonradioactive contaminants as required by the final EPA ground water protection standards in 40 CFR $\$ 192.02$ (a)(3) (60 FR 2854). The final ground water protection compliance strategy applies supplemental standards for limited use ground water. Protection of human health and the environment will be achieved because the uppermost aquifer has a low yield (less than $150 \mathrm{gpd}$ [6.6 $\left.\times 10^{-3} \mathrm{~L} / \mathrm{s}\right]$ ), as demonstrated in on-site aquifer performance tests. No known potable water supply wells exist within the uppermost aquifer in a $2-\mathrm{mi}(3-\mathrm{km})$ radius of the disposal site. The uppermost aquifer is hydrogeologically isolated from underlying saturated units by thick (50- to 65-ft [15- to 20-m]) mudstone units and by significant upward vertical hydraulic gradients. A narrative supplemental standard is provided in Section 5.3.2.

The ground water protection standard consists of three components: 1 ) a list of hazardous constituents, 2) a corresponding list of concentration limits for the constituents, and 3) a point of compliance (POC) (NRC, 1989). The DOE has identified hazardous constituents in the tailings pore fluids measured in lysimeter samples and in shallow alluvial ground water at the processing sites. For this narrative supplemental standard application, no concentration limits or POCs have been established for the identified potentially hazardous constituents because the uppermost aquifer at the Burro Canyon disposal site meets the insufficient yield criteria of limited use ground water, as defined in 40 CFR $\$ 192.11(\mathrm{e})$ of the final EPA ground water standards (60 FR 2854). There is no historic or current beneficial use of ground water in the upper sandstone unit of the Burro Canyon Formation. As a result, defining concentration limits and a POC would not further protect human health and the environment. A demonstration that the remedial action is as close as reasonable to meeting the otherwise applicable standard is presented in Section 5.3.2.

\section{Hazardous constituents}

Hazardous constituents at the Burro Canyon disposal site were identified from characterization of the tailings materials. A description of the uranium recovery process and an evaluation of ground water quality data are included in Attachment 3.

Hazardous constituents potentially of concern at the Burro Canyon disposal site have been determined, based on two criteria: 1 ) they must be present in (or reasonably expected to be present in) or derived from the RRM to be stabilized at the disposal site, and 2) they must be constituents listed in the final EPA ground water protection standards (60 FR 2854).

Average concentrations or activities of eight inorganic hazardous constituents with MCLs that 1 ) are related to uranium processing activities, and 2) exceeded laboratory method detection limits in the lysimeter pore fluid samples from the NC or UC sites include arsenic, cadmium, lead, molybdenum, net gross alpha, 
nitrate, selenium, and uranium. Six additional hazardous constituents without MCLs that exceeded the laboratory method detection limits are antimony, copper, thallium, tin, vanadium, and zinc. Table 5.3 summarizes the hazardous constituents identified at the UC and NC processing sites.

Ground water at the processing site was screened for the organic hazardous constituents. One organic screening ground water sample was collected from a DOE monitor well at the NC processing site and another was collected from a DOE monitor well at the UC processing site. No organic hazardous constituents were detected in the monitoring well sample collected from the UC processing site. Two organic compounds were detected in the NC ground water sample; however, the concentrations of the detected organic compounds are believed to be the result of laboratory contamination, rather than from the processing operations at the NC site. Additional discussion is provided in Section 3.1.6 of Attachment 3.

The DOE has evaluated the potential effects of relocating the tailings to the Burro Canyon disposal site and has determined that because the uppermost aquifer has a low yield (less than $150 \mathrm{gpd}\left[6.6 \times 10^{-3} \mathrm{~L} / \mathrm{s}\right]$ ) and is not a current or potential source of water, hazardous constituents from the tailings source term will not affect human health and the environment. The Burro Canyon disposal cell will minimize release of the hazardous constituents identified in Table 5.3. Approximately 50 to $65 \mathrm{ft}(15$ to $20 \mathrm{~m})$ of low-permeability $(2.3 \mathrm{x}$ $10^{-6} \mathrm{~cm} / \mathrm{s}\left[6.5 \times 10^{-3} \mathrm{ft} /\right.$ dayl] interbedded mudstone and siltstone sequences will separate the base of the disposal cell from the uppermost aquifer (upper sandstone unit of the Burro Canyon Formation). The upper sandstone unit is hydrogeologically separated from the middle sandstone unit by another 60 to $70 \mathrm{ft}$ (about $20 \mathrm{~m}$ ) of mudstone and by an upward vertical gradient. As a result, if any potentially hazardous constituents are released below the disposal cell foundation, the low-permeability mudstone and siltstone sequences are expected to limit further migration. Therefore, the disposal cell design should result in human health standards being met in the first potentially usable aquifer beneath the disposal cell (the middle unit of the Burro Canyon Formation). Additional discussion of potential points of exposure is presented in Section 5.3.3. The uppermost aquifer is hydrogeologically isolated from the underlying water bearing units by low-permeability mudstone and upward vertical gradients, as discussed in Attachment 3.

\section{Proposed concentration limits}

To achieve compliance with the final EPA ground water protection standards (60 FR 2854) at the disposal site, the DOE proposes to apply a narrative supplemental standard based on limited use ground water due to insufficient yield in the uppermost aquifer. A narrative supplemental standard is reasonable for the Burro Canyon disposal site for the following reasons: 
Table 5.3 Summary of hazardous constituents identified at the Slick Rock, Colorado, processing sites ${ }^{\mathrm{a}}$

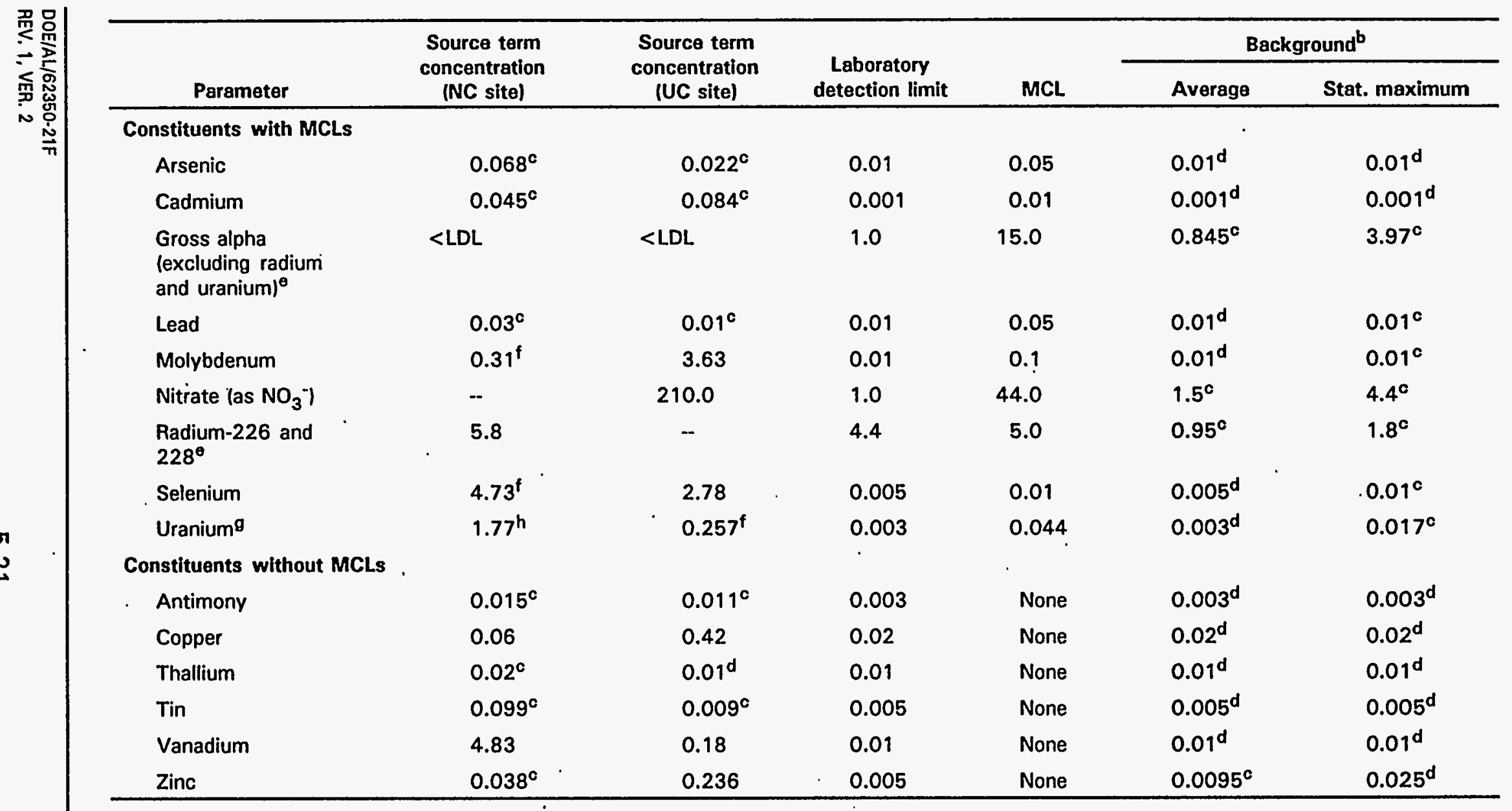

${ }^{a}$ All units are in milligrams per liter unless otherwise noted. Source-term concentrations are based on lysimeter samples collected from January 1989 to October 1992.

background ground water quality in the Burro Canyon Formation, upper sandstone unit (uppermost aquifer).

cNonparametric distribution.

${ }^{d}$ Statistical values are below laboratory detection limits in Table 8.1 of the Technical Approach Document (DOE, 1989).

Units are picocuries per liter.

fNormal distribution; mean is arithmetic.

${ }^{9}$ Confirmation of equilibrium between uranium isotopes (U-234/-238) will be undertaken as part of the ground water monitoring program.

hLognormal distribution; mean is geometric.

$<L D L=$ value is less than laboratory detection limit.

Dash indicates constituent is not present. 
- The quantity of water available is less than $150 \mathrm{gpd}\left(6.6 \times 10^{-3} \mathrm{~L} / \mathrm{s}\right)(40$ CFR $\$ 192.11(e)(3)$ ), as demonstrated by on-site aquifer performance testing.

- Due to limited yield, there is no historic or existing beneficial use of the ground water in the uppermost aquifer.

- The proposed disposal cell foundation will be separated from the uppermost aquifer by a thick layer of low-permeability mudstone (50 to $65 \mathrm{ft}[15$ to $20 \mathrm{ml}$ ).

- Ground water in the sandstone units underlying the uppermost aquifer is protected from potential site-related contamination by the low-permeability mudstone units that inhibit the downward migration of water and steady state upward vertical hydraulic gradients in the lower and middle sandstone units of the Burro Canyon Formation.

- There is no evidence of discharge anywhere in the vicinity of the site; therefore, there is no point of exposure.

- The remedial action at the Burro Canyon disposal site comes as close to meeting the otherwise applicable standards (40 CFR Part 192) as is reasonable under the circumstances (see Section 5.2 for a discussion of disposal cell design features for protection of ground water). A discussion of how the remedial action at the Burro Canyon disposal site will protect human health and the environment is provided in Section 5.3.3.

\section{Point of compliance}

A POC has not been established for the Burro Canyon disposal site for the reasons previously discussed.

\subsubsection{Narrative supplemental standard}

The NRC must consider the following four items before granting supplemental standards (NRC, 1989); 1) the criteria for applicability, 2) description of the supplemental standard, 3) demonstration that the remedial action satisfies the proposed supplemental standard, and 4) demonstration that the supplemental standard is as low as reasonable under the circumstances. Items 1,3 , and 4 are discussed in this section. Item 2 is discussed in Section 5.3.1.

\section{Applicability criteria}

To achieve compliance with the final EPA ground water protection standards, the DOE proposes the application of a narrative supplemental standard (Subpart C of 40 CFR Part 192) at the Burro Canyon disposal site. Ground water in the uppermost aquifer meets the definition of limited use (40 CFR $\$ 192.11$ (e)) 
based on insufficient yield and ground water use. These criteria are discussed below.

The EPA defines "sufficient yield" as a quantity of water from a well or spring sufficient to meet the long-term needs of an average family (EPA, 1986). The yield must be sustainable into the future. The EPA has estimated that the lowest quantity that meets this requirement is $150 \mathrm{gpd}\left(6.6 \times 10^{-3} \mathrm{~L} / \mathrm{s}\right)$. Ground waters with yields less than this criterion are defined as limited use.

The ground water protection standards in 40 CFR \$192.02(a)(3) apply to the uppermost aquifer hydraulically downgradient from the disposal unit. The upper sandstone unit of the Burro Canyon Formation is the uppermost aquifer at the Burro Canyon disposal site. Ground water in this unit occurs under semiunconfined conditions at constant levels and does not show seasonal fluctuations. The upper sandstone unit is not a current or potential source of drinking water because the quantity. of water available is less than $150 \mathrm{gpd}$ (6.6 $\times 10^{-3} \mathrm{~L} / \mathrm{s}$ ), as evidenced by on-site aquifer performance tests. As a result, the ground water in the upper sandstone unit is limited use ground water, as defined in 40 CFR $\$ 192.11$ (e) of the final EPA ground water standards (60 FR 2854). Furthermore, the upper sandstone unit is hydrogeologically isolated from the underlying middle and lower sandstone units, as discussed in Section 3.2.3 of Attachment 3.

By definition, limited use ground water is not a current or potential source of drinking water. No known registered or private wells are actively used within the upper sandstone unit of the Burro Canyon Formation in a 2-mi $(3-\mathrm{km})$ radius of the Burro Canyon disposal site, because of limited yield. . Furthermore, ground water development in the vicinity of the disposal site should not increase over the next 50 years, because there is not enough water available to support development on any time scale.

Demonstration that remedial action satisfies the proposed supplemental standard

This section describes potential impacts of ground water use to human health and the environment. There are no historic or existing beneficial uses of ground water in the upper sandstone unit of the Burro Canyon Formation, based on the applicability criteria discussed above.

Human health and the environment will be protected for the following reasons:

- The quantity of water available is less than $150 \mathrm{gpd}\left(6.6 \times 10^{-3} \mathrm{~L} / \mathrm{s}\right)(40$ CFR \$192.11(e)(3)), preventing future ground water development and use.

- Ground water in the uppermost aquifer beneath the Burro Canyon disposal site is not a current or potential source of drinking water. 
- The Burro Canyon disposal cell foundation will be separated from the uppermost aquifer by 50 to $65 \mathrm{ft}(15$ to $20 \mathrm{~m})$ low-permeability mudstone.

- The first potentially usable aquifer beneath the disposal site, the middle sandstone unit, will meet human health standards because it is separated from the disposal cell by over $100 \mathrm{ft}(30 \mathrm{~m})$ of mudstone (including the upper and middle mudstone units of the Burro Canyon Formation, collectively) and steady-state upward vertical hydraulic gradients in the middle and lower sandstone units, thus inhibiting the downward migration of water.

- There is no point of exposure downgradient from the disposal site. Details are provided in Section 5.3.3.

\section{As low as reasonable under the circumstances}

The Burro Canyon disposal cell design meets the as low as reasonable under the circumstances criterion. The design features, described in Section 5.2, will ensure that human health and the environment are protected. Active maintenance will not be required to ensure long-term performance. The Burro Canyon disposal embankment cover will use natural, stable materials to prevent surface erosion, provide protection against freezing and thawing, and inhibit radon emanation and water seepage, by incorporating design features that are as close to meeting the otherwise applicable standards as are reasonable under the circumstances.

\subsubsection{Point of exposure}

Pursuant to 40 CFR Part 192, this section assesses the potential for human and environmental exposure and concludes that the probability of exposure is low enough to prevent adverse impacts from ground water contamination. For this discussion, points of exposure can be divided into two categories: 1) surface expressions where water enters the uppermost aquifer as precipitation and outflows as surficially exposed drainage, and 2) subsurface drainage.

\section{Surface points of exposure}

The upper sandstone unit is recharged by infiltration of water from the surface outcrop upgradient of the site. Sandstone beds outcrop along the east limb of the Disappointment syncline and intercept tributaries to the Nicholas Wash drainage system. Ground water movement in the upper sandstone unit parallels the axis of the Disappointment syncline and eventually dissipates (discharges) into the Burro Canyon Formation southeast of the disposal site (Figure 5.5). The Burro Canyon Formation has a grade of approximately 3 percent. Joe Davis Canyon is about $1 \mathrm{mi}(2 \mathrm{~km})$ south of the disposal site. Based on a cross section shown in Figure 5.6 (modified from Shawe et al., 1968), the upper sandstone unit of the Burro Canyon Formation is present only as a cap at the top of Joe Davis Canyon. Any potential seepage into Joe Davis Canyon from 


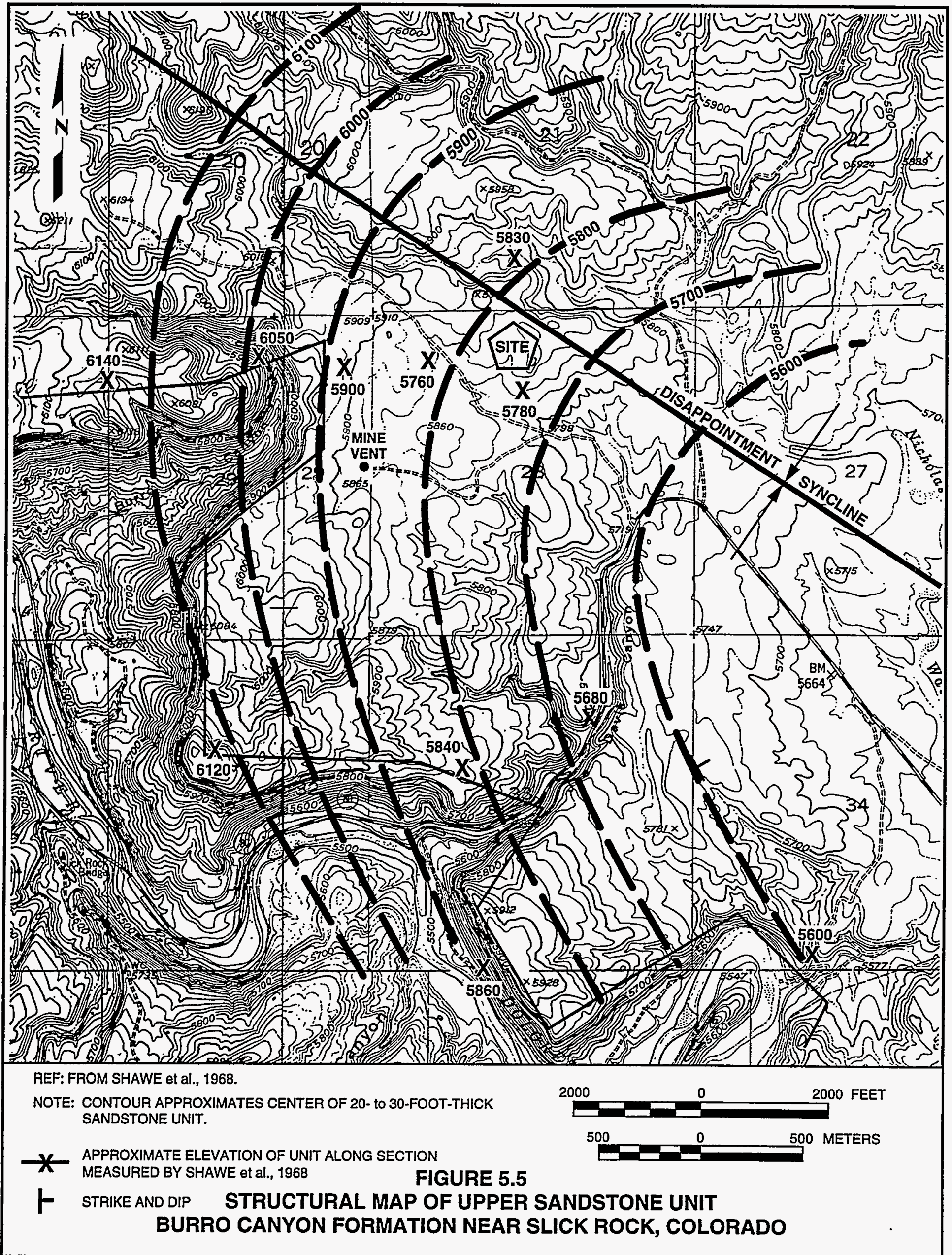


NOTE: PORTION OF SECTION B-B' SHOWN BELOW

SHADED ON LOCATION MAP.

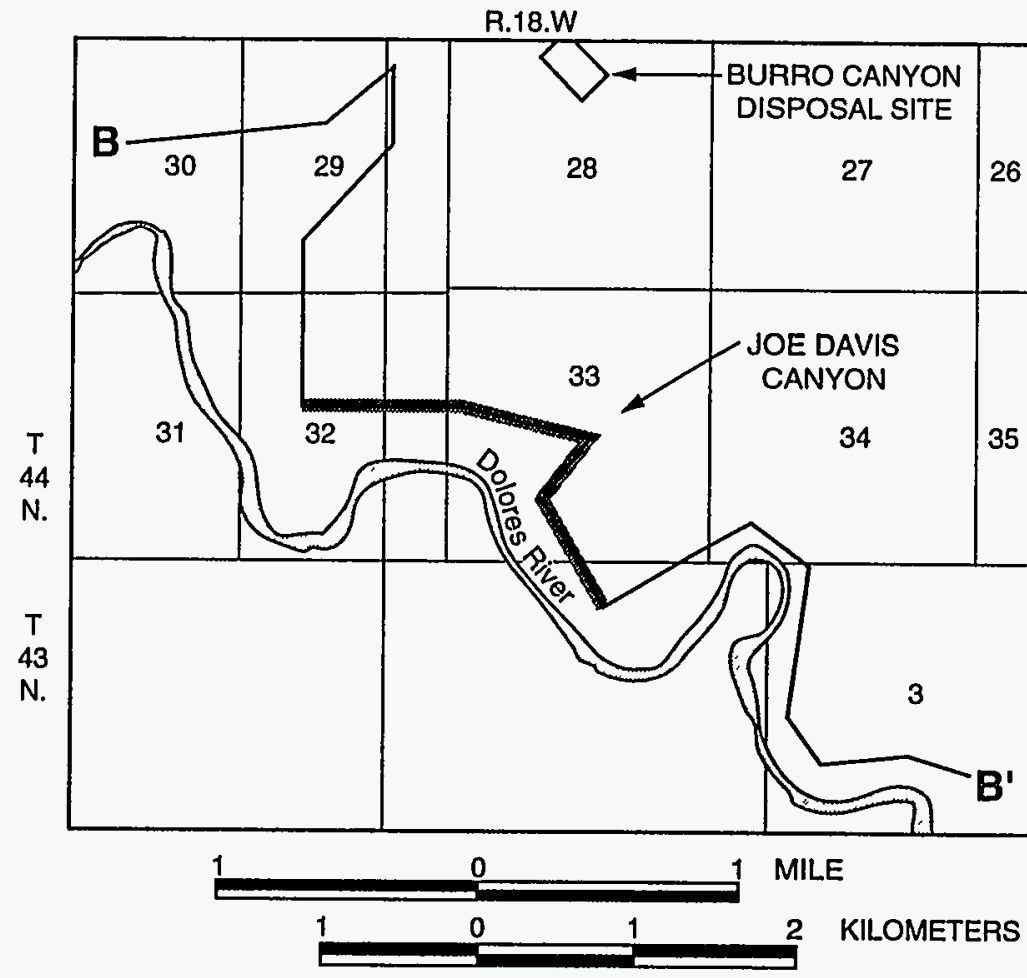

1

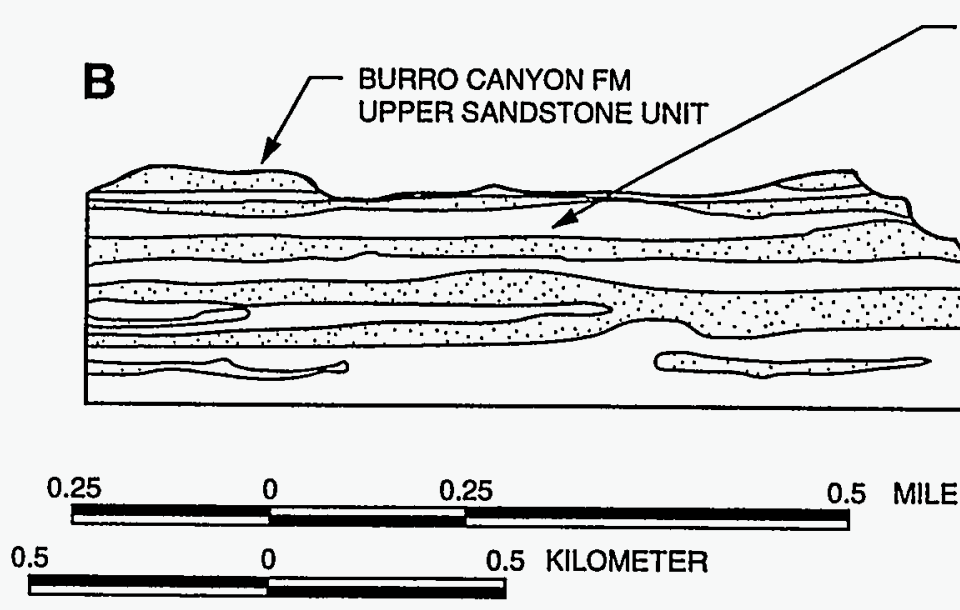

BURRO CANYON FM MIDDLE SANDSTONE UNIT

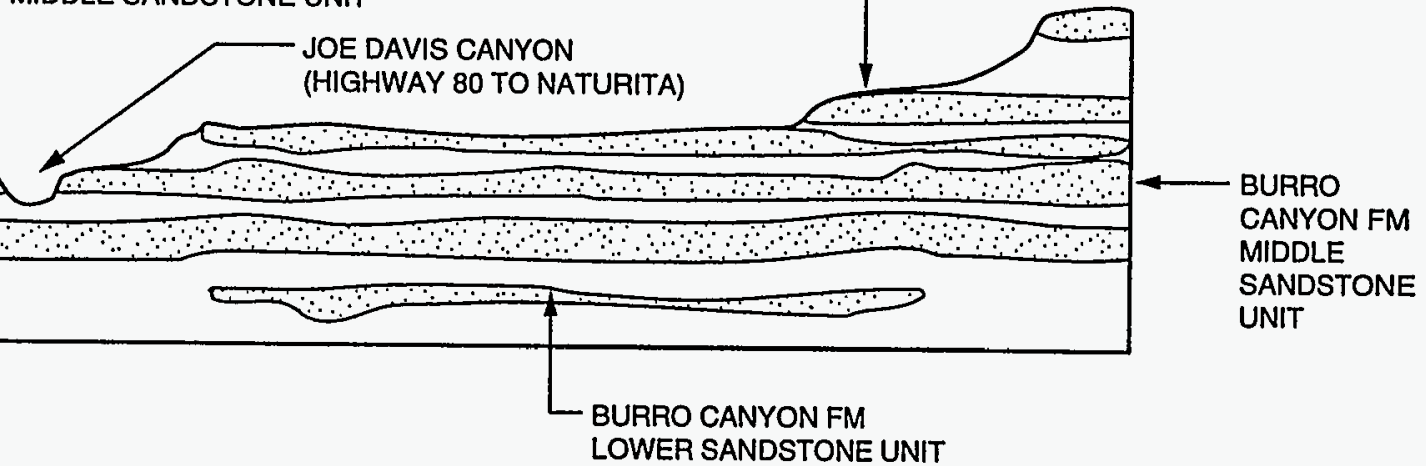

FIGURE 5.6

FROM SHAWE et al., 1968.

REPRESENTATIVE DIAGRAMMATIC SECTION OF STRATA BURRO CANYON FORMATION NEAR SLICK ROCK, COLORADO 
the Burro Canyon Formation is expected to be from the middle and/or lower Burro Canyon Formation sandstone units. Furthermore, based on the direction of ground water movement, Joe Davis Canyon is crossgradient from the Burro Canyon disposal cell. Therefore, any potential leachate from the disposal cell would never reach Joe Davis Canyon.

Additional potential points of exposure include two thin sandstone layers of the Dakota Sandstone that outcrop at the base of the disposal cell mesa within 200 to $300 \mathrm{ft}(60$ to $90 \mathrm{~m})$ of the toe of the disposal cell. As the Dakota Sandstone is incised during disposal cell construction, the lateral migration of contaminated pore fluid through relatively permeable sandstone layers is a potential concern. A water balance calculation was performed to assess whether contaminated fluid could leach from the disposal cell through the thin sandstone layers of the Dakota Sandstone and form seeps where the layers outcrop at the base of the small mesa (Appendix C to Attachment 3, Calculation No. SRK-09-94-12-0100). Data collected from the Burro Canyon disposal site, laboratory tests, and measurements reported in the literature were used in this calculation. Given that the sand tailings are very dry (level of saturation is less than 20 percent) and little water addition is required to meet either compaction or dust control requirements, almost no water is available to cause lateral or vertical seepage.

The disposal cell design calls for excavating to a depth of 10 to $36 \mathrm{ft} 13.0$ to $10.9 \mathrm{~m}$ ) into the claystones and mudstones at the base of the Dakota Sandstone and Burro Canyon Formation upper mudstone unit. These natural foundation materials will cut off any potential pathways of seepage and create a liner effect.

The excavated mudstone/claystone will provide an impermeable layer from the base of the pit ranging from 7 to $39 \mathrm{ft}(2.0$ to $12 \mathrm{~m})$ up the side wall, effectively forming a continuous saucer-shaped bottom and side liner. These natural, low-permeability mudstone and claystone materials will further mitigate any potential of a saturation front moving into the sandstone stringers of the Dakota Sandstone.

This calculation demonstrated that the relatively small volume of leachate from the dry sand tailings will not create seeps at the base of the mesa at the Burro Canyon disposal site.

\section{Subsurface points of exposure}

Subsurface drainage potentially could result from transient drainage of excess moisture from the tailings. The tailings at the Slick Rock sites consist of sand and poorly-graded sand with silt. The tailings saturated hydraulic conductivity is approximately $140 \mathrm{ft} /$ day $\left(4.9 \times 10^{-2} \mathrm{~cm} / \mathrm{s}\right)$, which is characteristic of a clean, free-draining sand (Freeze and Cherry, 1979). As a result, the tailings will have a low moisture content when they are placed in the disposal cell. This low moisture content of the RRMs, coupled with a $1.5-\mathrm{ft}(0.45-\mathrm{m})$-thick radon 
barrier, will inhibit radon emanation and water seepage through the underlying contaminated material.

Approximately 50 to $65 \mathrm{ft}(15$ to $20 \mathrm{~m})$ of low-permeability $\left(6.5 \times 10^{-3} \mathrm{ft} /\right.$ day $\left.\left[2.3 \times 10^{-6} \mathrm{~cm} / \mathrm{s}\right]\right)$ interbedded mudstone and siltstone sequences will separate the base of the disposal cell from the upper sandstone unit of the Burro Canyon Formation. Ground water in lithologic units underlying the uppermost aquifer also is protected from potential seepage from the disposal cell by 1) hydrogeologic isolation, provided by the low-permeability Burro Canyon mudstone units that inhibit the downward migration of water, and 2) upward vertical hydraulic gradients in the lower and middle sandstone units of the Burro Canyon Formation.

\subsection{PERFORMANCE ASSESSMENT AND DEMONSTRATION}

The DOE is required to demonstrate that the performance of the disposal cell will comply with the final EPA ground water protection standards in 40 CFR $\$ 192.02$ (a)(3) (60 FR 2854). To achieve compliance, the DOE proposes to apply supplemental standards, because the uppermost aquifer is not a current or potential source of drinking water due to limited yield.

Aquifer performance testing has been conducted at the Burro Canyon disposal site to assess the hydraulic properties and amount of interconnection between the saturated units of the Burro Canyon Formation. The results of these and other site-specific hydrogeologic investigations (described in Attachment 3) demonstrate that ground water is protected from potential site-related contamination in the upper sandstone unit of the Burro Canyon Formation (uppermost aquifer) and in the underlying sandstone units. Hydrogeologic isolation is provided by the low-permeability mudstone units above and below the uppermost aquifer and by upward vertical hydraulic gradients in the middle and lower sandstone units of the Burro Canyon Formation.

The DOE has demonstrated that the proposed RAP at the disposal site will comply with Subpart A of the final EPA ground water protection standards in 40 CFR Part 192 (60 FR 2854). The disposal cell will minimize the release of hazardous constituents to ground water and surface water and will minimize radon emissions to the atmosphere to the extent necessary to protect human health and the environment (40 CFR \$192.02(a)(4)). Natural, stable materials have been proposed for use in the construction of the disposal cell so that long-term performance is ensured (see Section 3.3). The DOE also has demonstrated that design features necessary for compliance with the ground water protection standards minimize the need for further disposal site maintenance. Because sustainable amounts of ground water are not available from the upper sandstone unit, no existing or potential users are in the area. 


\subsection{GROUND WATER MONITORING}

Pursuant to 40 CFR $\$ 192.02(a)(4)(b)$, this section addresses a ground water monitoring plan to be carried out during and after the remedial action period. The DOE has determined that proposing concentration limits and monitoring a POC at the Burro Canyon disposal site would not further protect human health and the environment for the reasons discussed in Sections 5.3.1 and 5.3.2. Section 5.3.3 provides an assessment of the potential effects of exposure on human health and the environment and a determination that the probability of exposure will be low enough to prevent adverse impacts from ground water contamination. Points of exposure have been divided into two categories: 1) surface expressions where the source of recharge is precipitation and discharge is surficially exposed drainage, and 2) subsurface drainage. Ground water monitoring would not be effective at the Burro Canyon disposal site, and is therefore not proposed, because insufficient yield in the uppermost aquifer will preclude its future use. Stand pipes will be installed in the bottom of the disposal cell to drain any accumulating water, using sump pumps, during remedial action construction. The only point of exposure that could potentially affect human health or the environment would be surface seepage at the base of the disposal cell mesa. In lieu of ground water monitoring, the DOE will conduct long-term surveillance monitoring by conducting inspections to locate surface expressions of seepage at and in the vicinity of the Burro Canyon disposal site. These visual inspections will include looking for physical evidence of mineralization, phreatophyte vegetation, and the presence of saturated zones at sandstone outcrops. Additionally, the DOE will monitor lateral movement of tailings fluids through the installation of a minimum of one piezometer in the sandstone lenses of the Dakota Sandstone near the toe of the cell. The details will be provided in the long-term surveillance plan.

\subsection{GROUND WATER CLEANUP}

The DOE is responsible for demonstrating compliance of cleanup or control of existing processing-related ground water contamination at the Slick Rock sites with the final EPA ground water protection standards in Subparts $B$ and $C$ of 40 CFR Part 192.

\subsubsection{Ground water cleanup standard}

The current level of site characterization is sufficient to address only whether remedial action (relocation of RRM) will comply with the final EPA ground water protection standards. The DOE has decided that ground water compliance with Subpart $B$ will be addressed under a separate DOE program and will be part of a separate National Environmental Policy Act process. Additional ground water characterization may be conducted to include water quality, ground water flow, and aquifer properties. A conceptual ground water restoration strategy will be developed. 
The current level of characterization at the Slick Rock processing sites is sufficient to address only whether the remedial action will comply with Subpart A of the final EPA ground water protection standards (60 FR 2854). Additional investigations will be conducted as necessary to determine the appropriate ground water compliance strategy for the UC and NC processing sites. The surface remedial action will not preclude or interfere with any potential ground water remediation activities at these processing sites.

\subsubsection{Cleanup demonstration}

Demonstration of cleanup and control of existing processing-related ground water contamination will be addressed under a separate DOE UMTRA Project program and will be part of a separate process to comply with the National Environmental Policy Act. The proposed remedial action will not preclude or interfere with active ground water restoration at the processing sites, should it be required, because the tailings will be relocated to a remote disposal site.

\subsubsection{Cleanup monitoring program}

Ground water monitoring and site characterization will continue at the processing sites, as needed. Procedures for collecting, handling, and analyzing ground water samples are outlined in the UMTRA Project standard operating procedures (JEG, n.d.) on file at the UMTRA Project Document Control Center.

\subsection{WATER RESOURCES PROTECTION STRATEGY SUMMARY}

To achieve compliance with the final EPA ground water protection standards in Subpart A of 40 CFR Part 192 (60 FR 2854), the DOE proposes to apply supplemental standards for limited use ground water because of low yield (less than $\left.150 \mathrm{gpd}\left(6.6 \times 10^{-3} \mathrm{~L} / \mathrm{s}\right]\right)$ in the uppermost aquifer. The proposed remedial action will ensure protection of human health and the environment. A summary follows of the principal features of the water resources protection strategy for the Burro Canyon disposal site.

- Uranium tailings and associated contaminated materials at the UC and NC mill sites will be consolidated and relocated to the Burro Canyon disposal site. These materials will be placed in a partially below-grade disposal cell designed to reduce radon emanation, resist degradation, reduce infiltration, and withstand differential settlement.

- The disposal cell foundation and the site location will be optimized by the favorable hydrogeologic and geochemical conditions of the site. A multiplecomponent cover has been designed, consisting of the following layers, in descending order: 1) riprap, to prevent erosion of the disposal cell by surface water runoff; 2) a sand and gravel bedding layer, to prevent displacement of large-diameter rock, protect the underlying frost protection layer from erosion, and drain water laterally; 3) a frost-protection layer (finegrained soil with some sand), to protect the radon/infiltration barrier from 
the effects of freezing and thawing; and 4) a sandy clay radon barrier, to inhibit radon emanation and infiltration through the underlying contaminated material. The excavation will penetrate the low-permeability claystone and mudstones of the Burro Canyon Formation to provide the base of the cell an impermeable barrier to vertical migration.

- Low moisture contents in the sand tailings (level of saturation less than 20 percent) and the addition of little water during construction will limit the volume of water that could create a saturated zone (pond) at the contact of the Burro Canyon Formation.

- The proposed ground water protection compliance strategy applies supplemental standards. The demonstrated quantity of water available from the uppermost aquifer is less than $150 \mathrm{gpd}\left(6.6 \times 10^{-3} \mathrm{~L} / \mathrm{s}\right)$ and is classified as limited use because it refers to ground water that is not a current or potential source of drinking water.

- Ground water in lithologic units underlying the upper sandstone unit of the Burro Canyon Formation (uppermost aquifer) is protected from potential siterelated contamination by hydrogeologic isolation provided by the lowpermeability mudstone units that inhibit downward migration of water.

- Ground water monitoring would not be effective at the Burro Canyon disposal site, and is therefore not proposed, because insufficient yield in the uppermost aquifer will preclude its future use. The only point of exposure that could potentially affect human health or the environment would be surface seepage at the base of the disposal cell mesa. Stand pipes will be installed in the bottom of the disposal cell to drain any accumulating water, using sump pumps, during remedial action construction. In lieu of ground water monitoring, the DOE will conduct compliance monitoring by conducting inspections to locate surface expressions of seepage at and in the vicinity of the Burro Canyon disposal site. These visual inspections will include looking for physical evidence of mineralization, phreatophyte vegetation, and saturated zones at sandstone outcrops. In addition to visual inspections, the DOE will install a minimum of one piezometer near the toe of the disposal cell to monitor lateral movement of tailings pore fluid. The screen or well point of the piezometer will be installed across the sandstone lenses of the Dakota Sandstone. Monitoring details will be provided in the long-term surveillance and monitoring plan.

- Demonstration of cleanup and control of existing processing-related ground water contamination at the UC and NC sites will be addressed under a separate DOE UMTRA Project program and will be part of a separate process to comply with the National Environmental Policy Act. The proposed surface remedial action will not preclude or interfere with active ground water restoration at the processing site, should it be required, because the tailings will be relocated to a remote disposal site. 


\subsection{RADON ATTENUATION AND SITE CLEANUP}

\subsection{INTRODUCTION}

This section summarizes the disposal cell design and relevant parameters used to evaluate the radon barrier, site radiological characteristics, and radiological survey plan to provide reasonable assurance that compliance with the final EPA standards outlined in 40 CFR Part 192 (60 FR 2854) will be achieved.

\subsection{DESIGN}

The proposed remedial action will consolidate contaminated materials from the NC and UC areas within the boundaries of the designated Slick Rock sites into a single disposal cell at the Burro Canyon disposal site. The approximate volume of these contaminated materials is $621,000 \mathrm{yd}^{3}\left(475,000 \mathrm{~m}^{3}\right)$. In addition, an estimated $3000 \mathrm{yd}^{3}\left(2000 \mathrm{~m}^{3}\right)$ of uncontaminated demolition debris from the recreation building, other site structures, and on-site scrap materials will be disposed of in the main disposal cell. Efforts will be made to place materials with relatively low radium-226 concentrations over materials with higher concentrations. A compacted (95 percent) earthen radon barrier $1.5-\mathrm{ft}$ $(0.45-\mathrm{m})$-thick will be placed directly over the contaminated material. The sequencing of contaminated material within the cell and cover replacement will reduce the radon flux to below the EPA standards, to levels that are as low as reasonably achievable (ALARA).

Additional cover components will be placed sequentially above the primary earthen radon barrier. On the topslope, these components will consist of a 2.0-ft $(0.61-\mathrm{m})$-thick frost-protection layer, a 6 -inch $(150-\mathrm{mm})$-thick bedding layer, and an 8-inch (200-mm)-thick riprap layer. The sideslopes will contain the same layers as the topslope; however, the sideslope riprap layer will be $1.0 \mathrm{ft}$ $(0.3 \mathrm{~m})$ thick.

The radon barrier, frost-protection layer, and bedding layer all will contribute to the reduction of surface radon flux; however, to be conservative, only the radon barrier was considered in the radon flux attenuation calculations.

\subsection{RADON BARRIER PARAMETERS}

The radon barrier design parameters and supporting calculations were used in conjunction with the RAECOM model (NRC, 1984) to determine the cover thickness needed to control radon flux to meet the EPA standard of $20 \mathrm{pCi} / \mathrm{m}^{2} \mathrm{~s}$. Procedures for determining the thickness of the radon barrier are described in the TAD (DOE, 1989).

Specific parameters discussed below include long-term moisture content, radon diffusion, radon emanation, bulk density, specific gravity, porosity, layer thickness, and average radium-226 concentrations. The RAECOM input 
parameters for the Slick Rock materials are presented in Attachment 1 , Calculation No. 11-321-01-00 (Radon Barrier Design).

The planned source for the frost-protection material is the excavated Burro Canyon material. The frost-protection material may contain a slightly greater percentage of coarse material than the radon barrier. For purposes of calculation, 95 percent compaction was used for the radon barrier material, whereas 90 percent relative compaction was assumed for the frost-protection layer.

\subsubsection{Long-term moisture}

The average long-term moisture content for the earthen radon barrier and contaminated material was determined by using the optimum and capillary moisture content, the Rawls procedure, and the in situ residual moisture. In general, the lowest value obtained from the tests was selected to characterize the radon barrier. Eight radon barrier soil samples from the Burro Canyon borrow site were tested separately. The in situ residual moisture content was compared to the minus 15 bar capillary moisture content for the same sample, and the lower value was selected as the long-term moisture content of the sample. The average long-term moisture content was calculated to be 9.5 percent by weight using selected values of each sample. An average value of 6 percent was determined for the frost-protection layer.

Separate sample sets were tested from each of the representative areas of contamination to determine their respective long-term moisture content: the NC site (two samples) and the UC site (five samples). In situ moisture tests on these samples yielded values that are at or near typical residual moisture content values for similar materials. Therefore, minus 15 bar capillary suction measurements were not conducted on these samples. The volume-weighted average moisture contents for the NC site and UC site were 8.5 and 6.2 percent moisture by weight, respectively.

\subsubsection{Radon diffusion}

Average radon diffusion coefficients for the earthen radon barrier material and contaminated materials were determined using eight different cover soil samples and three and four soil samples from the NC and UC contaminated areas, respectively. Radon diffusion for each type of material was measured in the laboratory as a function of moisture content. For each soil sample, three to six diffusion measurements were made at moisture contents in a representative range around the estimated long-term moisture content mean. Test results for the cover and contaminated materials were plotted separately, and a best fit to an analytical model curve was obtained for each material category using a least squares methodology. An average radon diffusion coefficient of $1.5 \mathrm{E}-02 \mathrm{~cm}^{2} / \mathrm{s}$ was derived for the earthen component of the radon barrier. The calculated diffusion coefficient for the frost-protection layer was $0.039 \mathrm{~cm}^{2} / \mathrm{s}$. This value 
is rather conservative, being equivalent to a typical diffusion value for sand. Diffusion coefficients of $2.9 \mathrm{E}-02$ and $1.9 \mathrm{E}-02 \mathrm{~cm}^{2} / \mathrm{s}$ were estimated for the UC tailings and offpile material, respectively. A diffusion coefficient of $1.9 \mathrm{E}-02 \mathrm{~cm}^{2} / \mathrm{s}$ was estimated for the contaminated material from the NC site. Each diffusion coefficient value selected corresponds to the individual estimated long-term moisture content for the effective material.

\subsubsection{Radon emanation}

In general, radon emanation has been shown to be statistically independent of both moisture and radium-226 concentrations using standard regression and statistical analysis. Twelve standard measurements of radon emanation for NC tailings-contaminated materials ranged from 0.23 to 0.62 , with an arithmetic average of 0.42 and a standard error of the mean of \pm 0.03 . Fourteen standard measurements of radon emanation for UC tailings-contaminated materials ranged from 0.10 to 0.29 , with an arithmetic average of 0.19 and a standard error of the mean of \pm 0.02 . Nine standard measurements of radon emanation for UC offpile-contaminated materials ranged from 0.31 to 0.59 , with an arithmetic average of 0.45 and a standard error of the mean of \pm 0.03 . The UC subpiles had an average emanation fraction of 0.19 , giving a volume-weighted average for the UC subpile/offpile soils of $0.31+1-0.02$.

\subsubsection{Dry densities and porosities}

The dry densities, specific gravities, and porosities for the earthen radon barrier and contaminated materials were determined using standard tests, assuming a design compaction of 95 and 90 percent, respectively. Radon barrier soils had maximum dry densities ranging from 1.50 to 1.76 grams per cubic centimeter $\left(\mathrm{g} / \mathrm{cm}^{3}\right)$ and specific gravities of 2.65 to 2.75 , for separate measurements made on seven and five cover soil samples, respectively. An average density at 95-percent compaction of $1.64 \mathrm{~g} / \mathrm{cm}^{3}$ and an average specific gravity of 2.69 were used to obtain a representative porosity of 0.39 for the radon barrier.

The density for the frost barrier was calculated to be $1.56 \mathrm{~g} / \mathrm{cm}^{2}$ with a specific gravity of 2.67. Based on these values, a porosity of 0.418 was determined. As a result of special studies on the effects of freeze and thaw, an 11.5 percent increase in porosity is expected. Consequently, the porosity value has been adjusted to 0.466 for the frost-protection layer.

A representative number of contaminated material samples were tested for maximum dry density (22) and specific gravity (31). The respective average compacted density (90 percent compaction) and specific gravity for each contaminated area were $1.64 \mathrm{~g} / \mathrm{cm}^{3}$ and 2.70 for the UC offpile and subpile soils, $1.46 \mathrm{~g} / \mathrm{cm}^{3}$ and 2.69 for the UC tailings, and $1.51 \mathrm{~g} / \mathrm{cm}^{3}$ and 2.70 for the NC area. The estimated porosities for these soils, UC offpile/subpiles, UC tailings, and NC area overall were $0.39,0.46$, and 0.44 , respectively. 


\subsubsection{Layer thickness}

Specific thicknesses of three discrete layers of contaminated materials were calculated for NC site materials, UC tailings and subpile materials, and UC offpile materials. Thicknesses for the contaminated layers were calculated based on estimated volumes of materials and their ultimate geometric locations in the disposal cell, with layers sequentially placed in increasing numerical order from bottom to top. Volumes of materials were determined from radiometric measurements and radiological analyses of soil samples and from boring and test pit material collected across the Slick Rock sites. Information on layer thicknesses can be found in Calculation Nos. 11-212-01-01 and 11-321-02-00 of Attachment 1.

\subsubsection{Radium-226 concentrations}

Average radium-226 concentrations were estimated based on an assessment of radiometric measurements (hand-held and borehole gamma logs), and radiochemical and gamma spectroscopic measurements of contaminated material collected from surface soil samples, test pits, and boreholes within each subarea. Incremental radium-226 depth profiles were constructed at each measurement grid point within the subareas. The average radium-226 concentration for each subarea was determined by integrating the profiles over the volume contained between the topographical surfaces defining the ground surface and the excavation depth required to comply with EPA cleanup standards. Estimated design volumes are shown in Table 1.1 of this document.

\subsubsection{Ambient radon concentration}

An ambient radon concentration in air of $1.5 \mathrm{pCi} / \mathrm{L}$ was used for the RAECOM computer code. The code input for ambient radon concentrations was based on 24-hr background air samples collected with continuous radon samplers in the vicinity of the Slick Rock sites (FBDU, 1977). However, radon monitoring at the disposal site for four quarters prior to remedial action (August 1990 through August 1991) using integrating Track-Etch ${ }^{10}$ detectors indicates that an ambient radon concentration of $0.5 \mathrm{pCi} / \mathrm{L}$ is more appropriate (DOE, 1991). Using either radon concentration value will result in equivalent radon barrier design thickness determinations.

\subsection{EVALUATION OF RADON BARRIER}

The radon barrier was evaluated for compliance with the EPA radon flux standard of $20 \mathrm{pCi} / \mathrm{m}^{2} \mathrm{~s}$ using the above parameters (Section 6.3.7) in the RAECOM code. Only the clay material excavated at Burro Canyon that will be used as the frost-protection layer and the radon barrier directly over contaminated material were considered for these calculations. With a $2-\mathrm{ft}$ $(0.6-\mathrm{m})$ frost-protection layer, a minimum thickness of $1.5 \mathrm{ft}(0.45 \mathrm{~m})$ of radon barrier material is required to achieve a flux of $20 \mathrm{pCi} / \mathrm{m}^{2} / \mathrm{s}$ per the standard, assuming a worst-case scenario of average plus standard error of the mean 
values for all parameters. Considering the far likelier case based on average values for RAECOM parameters and the 2-ft $(0.6-\mathrm{m})$ frost-protection layer, the minimal radon barrier thickness would be $0.75 \mathrm{ft}(0.23 \mathrm{~m})$. The $1.5-\mathrm{ft}(0.46-\mathrm{m})$ for the proposed radon barrier, with the frost-protection layer and the bedding material not considered in the RAECOM calculations, provide clear and reasonable assurance of compliance with the final EPA 40 CFR Part 192 standard for radon flux.

\subsection{SITE CLEANUP}

Extensive field sampling and radiological surveys were conducted by several investigators to determine the extent and degree of contamination at the Slick Rock sites. Figure 6.1 shows the distribution of contaminated materials. Some of the areas shown in Figure 6.1 have been determined to be contaminated by uranium ore from mine runoff.

\subsubsection{Radiological site characterization}

Details of site characterization data are presented in Calculation No. 11-212-01-02 in Attachment 1. Measurements of background radioactivity near the Slick Rock sites and measurements of existing radiological site conditions are summarized in Table 6.1.

Approximately $621,000 \mathrm{yd}^{3}\left(475,000 \mathrm{~m}^{3}\right)$ of contaminated materials cover 69 ac (28 ha) at the Slick Rock processing sites. This excludes the contaminated soil thinly dispersed over 17 ac $(6.9 \mathrm{ha})$ in the floodplain area across the Dolores River from the UC sites where the DOE proposes to apply supplemental standards.

Additional areas of contamination outside the designated UC and NC sites were determined to be residual uranium ore transported by natural forces from uranium mining spoils or from naturally occurring uranium ore bodies. For example, there are a number of old uranium mines in the ridge above the floodplain north of the UC mill site (Area 1). Radionuclide ratios in samples collected from this area are typical of natural uranium ore (Attachment 1. Calculation No. 11-270-01-00). Therefore, there are no plans to remediate these areas. However, in the area across the river from the UC site some of the RRM may be windblown tailings from the site. This is the area for which supplemental standards will be requested. Additional sampling will be planned, as necessary, to confirm these conclusions.

Estimated design volumes for the various major contaminated materials are presented in Table 1.1. Depths of contamination range from less than $0.5 \mathrm{ft}$ $(0.2 \mathrm{~m})$ for windblown areas east of the Dolores River to approximately 14 and $50 \mathrm{ft}(4$ and $15 \mathrm{~m})$ at the NC and UC tailings piles, respectively. The radium-226 soil concentration at the NC and UC sites ranges from 1 to $8903 \mathrm{pCi} / \mathrm{g}$, with a volume-weighted average of $345 \mathrm{pCi} / \mathrm{g}$ for the NC site 


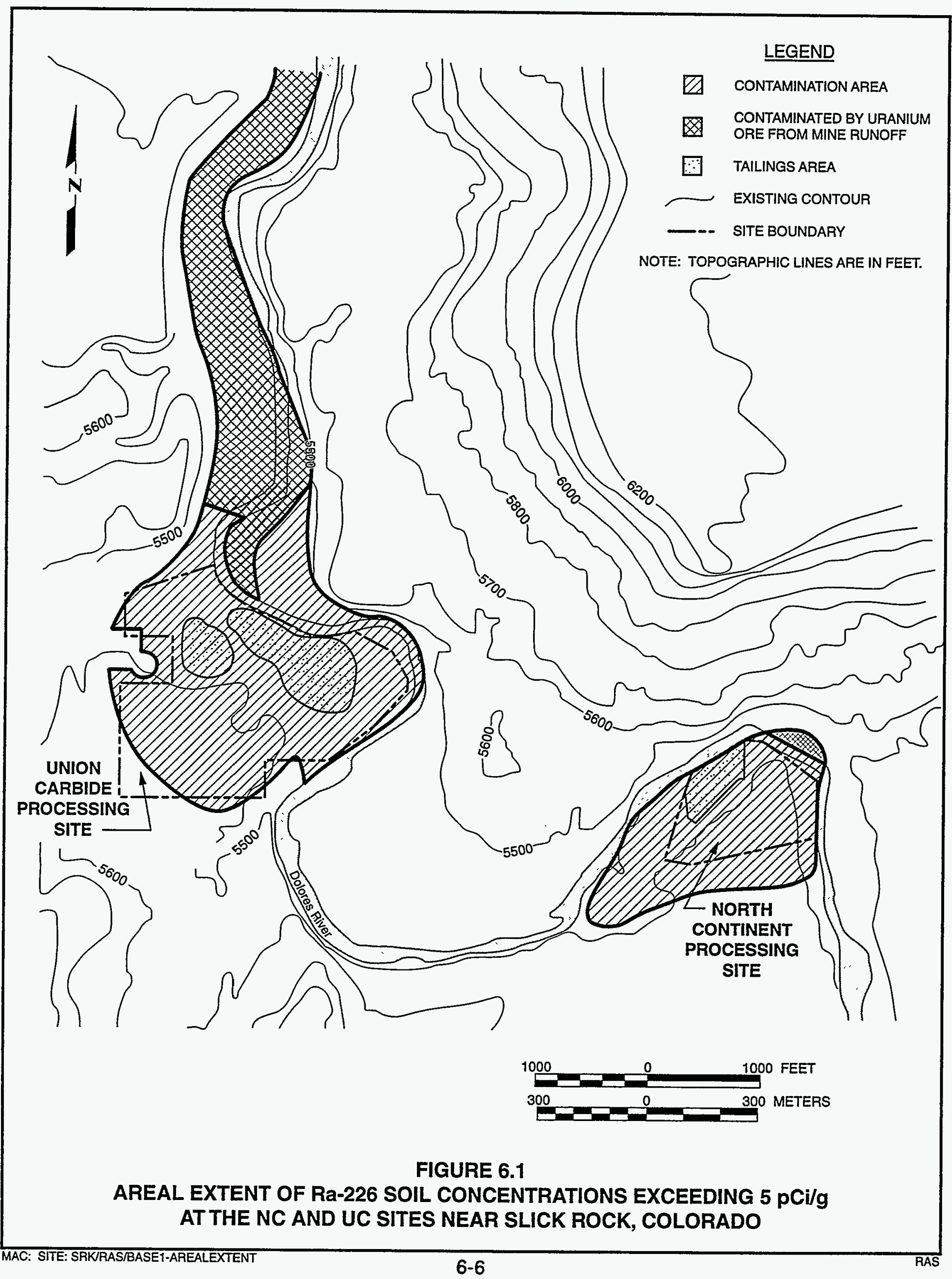


Table 6.1 Background radioactivity and radiological conditions at the Slick Rock, Colorado, sites

\begin{tabular}{lccc}
\hline \multicolumn{1}{c}{ Parameter } & Background & NC site & UC site \\
\hline Gamma exposure rate $\left(\mu \mathrm{R} / \mathrm{hr}^{\mathrm{a}}\right.$ & 13 & 160 & 63 \\
Radon-222 (pCi/L) & 0.5 & 4.1 & 1.4 \\
Radon flux $\left(\mathrm{pCi} / \mathrm{m}^{2} \mathrm{~s}\right)$ & $\mathrm{NA}$ & 240 & 70 \\
Radium-226 $(\mathrm{pCi} / \mathrm{g})^{\mathrm{b}}$ & 1.4 & 345 & . \\
\hline
\end{tabular}

${ }_{\mu} \mu \mathrm{R} / \mathrm{hr}-$ microroentgens per hour.

bolume-weighted average.

NA - not applicable.

materials, $135 \mathrm{pCi} / \mathrm{g}$ for the UC site tailings, and $35 \mathrm{pCi} / \mathrm{g}$ for the UC offpile and subpile materials.

\subsubsection{Standards for cleanup}

The DOE is committed to removing contaminated materials and placing them in an engineered, off-site disposal cell to meet all final EPA standards in $40 \mathrm{CFR}$ Part 192. Applying the supplemental standard provisions of 40 CFR Part 192 that are appropriate to vicinity properties will exclude the floodplain area across the Dolores River from the UC site from the remedial action. An appropriate application will be developed and submitted for NRC concurrence. The application will be based on the following conditions: limited long-term health impacts, presented by the low-level radium-226 contamination dispersed over an estimated $17 \mathrm{ac}$ (6.9 ha) with an average concentration of $7.4 \pm 1.4 \mathrm{pCi} / \mathrm{g}$ (the initial survey results will be verified to ensure that this criterion for applying supplemental standards is accurate. The evaluation shall be handled by an independent group from Oak Ridge National Laboratories [ORNL]). Human habitation of the area is unlikely because the river (on one side) and the steep cliffs (on the other) limit access to the site. Remedial action would be very costly due to the need for a temporary bridge across the Dolores River; furthermore, destruction of scarce riparian habitat during remedial action would result in long-term environmental harm.

All disturbed areas on the processing site and vicinity properties will be restored to grade for adequate control of surface drainage. Current plans do not include releasing contaminated material or buildings for unrestricted use; decontamination will achieve levels that meet EPA standards, NRC limits, and guidelines and requirements of the UMTRA Project Environmental, Health, and Safety Plan (DOE, 1992b). 


\subsubsection{Verification of cleanup}

Excavation control monitoring will be conducted during remedial action to prevent both inadequate underexcavation and costly overexcavation. Verification sampling will ensure radium-226 design standards are met for surface and subsurface soils (5 and $15 \mathrm{pCi} / \mathrm{g}$ above background). The verification survey will provide reasonable assurance of compliance with the standards.

Areas contaminated with thorium-230 will be excavated and verified in accordance with the NRC-approved generic protocol for thorium-230 cleanup and verification at UMTRA Project sites. This protocol is available at the UMTRA Project Document Control Center in Albuquerque, New Mexico (Surmeier, 1993).

The DOE and the TAC will conduct independent radiological and health/safety audits during remedial action to ensure that all activities are performed to meet federal, state, and local standards and guidelines. $Q C$ and $Q A$ requirements and procedures are in place to ensure that adequate cleanup and subsequent verification are properly implemented and documented (DOE, 1993).

Final verification surveys will document average radium-226 (and thorium-230, when applicable) concentrations in the top 6 -inch $(150-\mathrm{mm})$ layer of soil on all area grids less than or equal to $100 \mathrm{~m}^{2}$ at the site. Nine-plug, composite-surface soil samples will be collected above the water table for each grid area less than or equal to $100 \mathrm{~m}^{2}$ and analyzed by gamma spectroscopy or other analytical methods approved by the UMTRA Project Team to verify compliance with EPA standards.

In addition, a nine-point composite in situ gamma measurement technique may be used in windblown-contaminated areas. This hand-held verification protocol will be site-specific and must be approved by the UMTRA Project Team. The RTRAK mobile gamma detection unit may be used to verify contaminated areas that are too large to sample by hand methods. Verification sampling for thorium-230 will be performed in accordance with NRC-approved generic protocols for thorium-230 cleanup and verification at UMTRA Project sites.

If areas with cobbly soils are encountered during cleanup and verification, an NRC-approved procedure (MK-F, 1994) may be implemented at the site for bulk radionuclide concentration determinations, excavation depth control, and site verification. This approved procedure provides an appropriate quantitative method for cleanup and verification of soils that contain a high percentage of gravels, cobbles, and boulders.

\subsection{SUMMARY AND CONCLUSION}

The DOE is committed to cleaning up the Slick Rock sites in accordance with EPA standards, NRC guidelines, and UMTRA Project health and safety 
requirements. The disposal cell and radon barrier design will reduce the surface radon flux to levels below the final EPA standards defined in 40 CFR $\$ 192.02(b)$. Actual radon flux levels will be verified upon completion of the disposal cell to demonstrate compliance with 40 CFR Part 61, Subpart T, "National Emission Standards for Radon Emissions from the Disposal of Uranium Mill Tailings." Appropriate supplemental standards will be developed that will exclude the floodplain area across the river from the UC site from remedial action. Confirmation of the initial sampling assessment of this property shall be undertaken as a Vicinity Property Inclusion Survey, carried out by ORNL. These supplemental standards will be submitted for NRC approval. To date, data have been collected, verified, and analyzed to provide a reasonable preliminary disposal cell design; subsequent refinements of the final design will ensure the fulfillment of DOE's commitment. 


\subsection{LIST OF CONTRIBUTORS}

The following individuals contributed to the preparation of this report.

\begin{tabular}{|c|c|}
\hline Name & Contribution \\
\hline M. B. Leaf & Overall document responsibility \\
\hline D. Jones, P. Suniga & Document coordination \\
\hline G. Lindsey & Geology, seismicity \\
\hline K. Monks, K. Lambert & Hydrology, hydrogeology \\
\hline J. Crain & $\begin{array}{l}\text { Document coordination; engineering, surface water } \\
\text { hydrology }\end{array}$ \\
\hline A. Meijer & Geochemistry \\
\hline $\begin{array}{l}\text { W. James, G. Simiele, } \\
\text { M. Brennan }\end{array}$ & Radiation, health physics \\
\hline $\begin{array}{l}\text { L. Sanchez, P. Suniga, L. Keith, } \\
\text { c. Slosberg }\end{array}$ & Text processing \\
\hline $\begin{array}{l}\text { E. Bond, J. Brannan, B. Harvey, } \\
\text { E. Wagner }\end{array}$ & Graphic design \\
\hline J. Torline, D. Kale, D. Thalley & $\begin{array}{l}\text { Technical editing and document production } \\
\text { coordination }\end{array}$ \\
\hline
\end{tabular}




\subsection{REFERENCES}

ASTM (American Society for Testing and Materials), 1991. "Soil and Rock, Building Stones, Geotextiles," Annual Book of ASTM Standards, Volume 04.08, Philadelphia, Pennsylvania.

Campbell, K. W., 1981. "Near-Source Attenuation of Peak Horizonal Acceleration," in Bulletin of the Seismological Society of America, Vol. 71, pp. 2039-2070.

Cooley et al. (M. E. Cooley, J. W. Hershbarger, J. P. Akers, and W. F. Hardt), 1969. Regional Hydrogeology of the Navajo and Hopi Reservations, Arizona, New Mexico, and Utah, U.S. Geological Survey Professional Paper 521-A, Washington, D.C.

Daniel B. Stephens \& Associates, Inc., 1991. Laboratory Analysis of Soil Hydraulic Properties of the Burro Canyon Rock Samples, prepared for the U.S. Department of Energy, UMTRA Project Office, Albuquerque Operations Office, Albuquerque, New Mexico.

DOE (U.S. Department of Energy), 1994. Environmental Assessment of Remedial Action at the Slick Rock Uranium Mill Tailings Sites, Slick Rock, Colorado, DOE/EA-0339, Revision 2, prepared by the U.S. Department of Energy, UMTRA Project Office, Albuquerque Operations Office, Albuquerque, New Mexico.

DOE (U.S. Department of Energy), 1993. UMTRA Project Quality Assurance Plan, UMTRA-DOE/AL-185, Revision 4, prepared by the U.S. Department of Energy, UMTRA Project Office, Albuquerque Operations Office, Albuquerque, New Mexico.

DOE (U.S. Department of Energy), 1992a. Software Program for Environmental Analysis and Reporting (SPEAR) System, U.S. Department of Energy, UMTRA Project Office, Albuquerque Operations Office, Albuquerque, New Mexico.

DOE (U.S. Department of Energy), 1992b. UMTRA Project Environmental, Health, and Safety Plan, UMTRA-DOE/AL-150224.0006, DOE UMTRA Project Office, Albuquerque Operations Office, Albuquerque, New Mexico.

DOE (U.S. Department of Energy), 1991. Analysis of Infiltration through a Clay Radon Barrier at an UMTRA Disposal Cell, UMTRA-DOE/AL-400667.0000, prepared by the U.S. Department of Energy, UMTRA Project Office, Albuquerque Operations Office, Albuquerque, New Mexico.

DOE (U.S. Department of Energy), 1989. Technical Approach Document, UMTRA-DOE/AL-050425.0002, DOE UMTRA Project Office, Albuquerque Operations Office, Albuquerque, New Mexico. 
DOE (U.S. Department of Energy), 1986. Comparative Analysis of Disposal Site Alternatives Report for the UMTRA Project Slick Rock Sites Located at Slick Rock, Colorado, DOE UMTRA Project Office, Albuquerque Operations Office, Albuquerque, New Mexico.

EPA (U.S. Environmental Protection Agencyl, 1989. Statistical Analysis of Ground-Water Monitoring Data at RCRA Facilities-Interim Final Guidance, EPA/530-SW-89-026.

EPA (U.S. Environmental Protection Agency), 1986. Guidelines for Ground-Water Classification Under the EPA Ground-Water Protection Strategy, final draft, EPA Office of Ground-Water Protection, Office of Water, Washington, D.C.

FBDU (Ford, Bacon \& Davis Utah, Inc.), 1981. Engineering Assessment of Inactive Uranium Mill Tailings, Slick Rock Sites, Slick Rock, Colorado, DOE/UMT-0115, FBDU 360-07, UC 70, prepared by FBDU, Salt Lake City, Utah, for the U.S. Department of Energy, UMTRA Project Office, Albuquerque Operations Office, Albuquerque, New Mexico.

FBDU (Ford, Bacon \& Davis Utah Inc.), 1977. Engineering Assessment of the Inactive Uranium Mill Tailings, Slick Rock, Colorado, DOE/UMT-0115, prepared by FBDU, Salt Lake City, Utah, for the U.S. Department of Energy, Albuquerque Operations Office, Albuquerque, New Mexico.

Freeze, R. A., and J. A. Cherry, 1979. Ground Water, Prentice-Hall, Inc., Englewood Cliffs, New Jersey.

JEG (Jacobs Engineering Group Inc.), n.d. Albuquerque Operations Manual, standard operating procedures, prepared by Jacobs Engineering Group Inc., Albuquerque, New Mexico, Albuquerque Operations Office, Albuquerque, New Mexico.

Lindsey et al. (C. G. Lindsey, L. W. Long, and C. W. Begej), 1982. Long-Term Survivability of Riprap for Armoring Uranium Mill Tailings and Covers: $A$ Literature Review, NUREG/CR-2642, U.S. Nuclear Regulatory Commission, Washington, D.C.

MK-F (Morrison Knudsen-Ferguson), 1994. "Soil Verification Using Cobbles-to-Fines Corrections," OP-003-4, standard operating procedure.

NGDC/NOAA (National Geophysical Data Center and National Oceanic Atmospheric Administration), 1994. "Seismicity Within $150 \mathrm{Km}$ of $38.08 \mathrm{~N}, 108.87 \mathrm{~W}$," epicenter map and table of earthquake data, Boulder, Colorado.

NGDC/NOAA (National Geophysical Data Center and National Oceanic Atmospheric Administration), 1989. "Dry Flats site, Colorado: Epicentral Compilation for Magnitude $M=4$ and I = I-IV," Boulder, Colorado. 
NOAA (National Oceanic and Atmospheric Administration), 1977. Hydrometeorological Report No. 49, Probable Maximum Precipitation Estimates - Colorado River and Great Basin Drainages, Silver Spring, Maryland.

NRC (U.S. Nuclear Regulatory Commission), 1989. Standard Format and Content for Documentation of Remedial Action Selection at Title 1 Uranium Mill Tailings Sites, Staff Technical Position, February 24, 1989.

NRC (U.S. Nuclear Regulatory Commission), 1985. Standard Review Plan for the UMTRCA Title I Mill Tailings Remedial Action Plans, U.S. Nuclear Regulatory Commission, Washington, D.C.

NRC (U.S. Nuclear Regulatory Commission), 1984. Radon Attenuation Handbook for Uranium Mill Tailings Cover Design, NUREG/CR-3533, U.S. Nuclear Regulatory Commission, Washington, D.C.

PMET (Pittsburgh Mineral \& Environmental Technology), 1990. Chemical and Mineralogical Characterization of Soil Samples from Slick Rock, CO (Burro Canyonl, prepared by Wolfgang Baum of PMET, for Jacobs Engineering Group Inc., Albuquerque Operations Office, Albuquerque, New Mexico.

Shawe et al. (D. R. Shawe, G. C. Simmons, and N. L. Archibold), 1968. Stratigraphy of Slick Rock District and Vicinity, San Miguel and Dolores Counties, Colorado, U.S. Geological Survey Professional Paper 576-A, Washington, D.C.

Stephenson, D., 1979. Rockfill in Hydrologic Engineering, Elsevier Scientific Publishing Company, New York, New York.

Stevens et al. (M. A. Stevens, D. B. Simons, and G. L. Lewis), 1976. "Safety Factors for Riprap Protection," in Journal of Hydraulic Engineering, American Society of Civil Engineers.

Surmeier, J., 1993. Chief, Uranium Recovery Branch Division of Low-Level Waste Management \& Decommissioning, Office of Nuclear Materials Safety and Safeguards, U.S. Nuclear Regulatory Commission, Washington, D.C., personal communication to A. Chernoff, Jacobs Engineering Group Inc., UPDCC File Location No. 0.20.5.2.5, Albuquerque, New Mexico, 22 December 1993.

USACE (U.S. Army Corps of Engineers), 1970a. Laboratory Soils Testing, EM-1110-21906, U.S. Department of the Army, Office of the Chief of Engineers, Washington, D.C.

USACE (U.S. Army Corps of Engineers), 1970b. Hydraulic Design of Flood Control Channels, EM-1110-2-1601, U.S. Department of the Army, Office of the Chief of Engineers, Washington, D.C. 
USACE (U.S. Army Corps of Engineers), 1965. "Hydraulic Design of Spillways," EM11102-1603, U.S. Department of the Army, Office of the Chief of Engineers, Washington, D.C.

\section{CODE OF FEDERAL REGULATIONS}

40 CFR Part 61, National Emission Standards for Hazardous Air Pollutants, U.S. Environmental Protection Agency.

40 CFR Part 192, Health and Environmental Protection Standards for Uranium and Thorium Mill Tailings, U.S. Environmental Protection Agency.

\section{FEDERAL REGISTER}

60 FR 2854, Groundwater Standards for Remedial Actions at Inactive Uranium Processing Sites; Final Rule, 11 January 1995.

\section{UNITED STATES CODE}

42 USC $\$ 7901$ et seq., Uranium Mill Tailings Radiation Control Act, 8 November 1978. 
ATTACHMENT 2

GEOLOGY REPORT 
TABLE OF CONTENTS

Section

Page

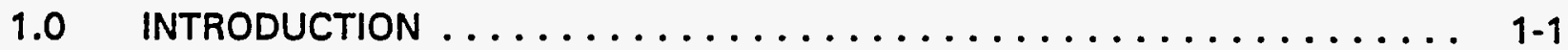

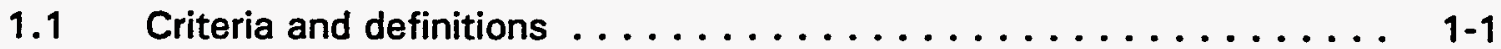

1.2 Scope of work ......................... 1-4

2.0 REGIONAL GEOLOGY ......................... 2-1

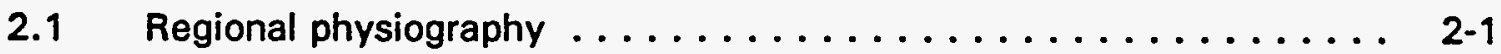

2.2 Stratigraphic setting ....................... 2-10

2.3 Structural setting ....................... 2-16

2.4 Seismotectonics .......................... 2-22

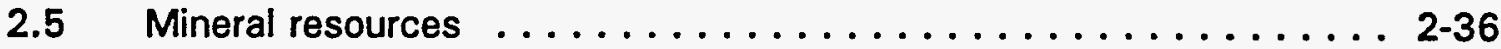

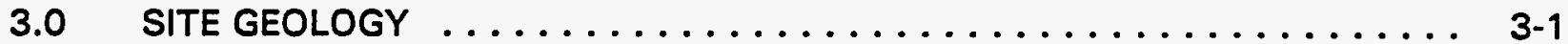

3.1 Bedrock geology $\ldots \ldots \ldots \ldots \ldots \ldots \ldots \ldots \ldots \ldots \ldots \ldots$

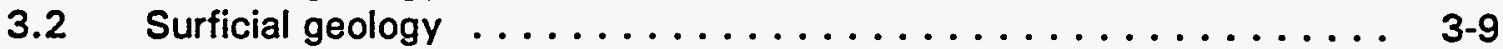

3.3 Geomorphology ......................... 3-9

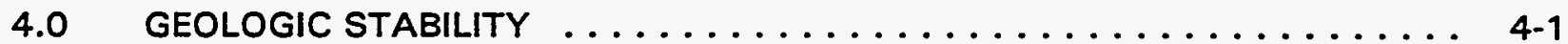

4.1 Geomorphic stability ..................... 4 . . .

4.2 Seismotectonic stability .................... 4 .

$5.0 \quad$ GEOLOGIC SUITABILITY $\ldots \ldots \ldots \ldots \ldots \ldots \ldots \ldots \ldots \ldots \ldots \ldots$

5.1 Foundation materials ...................... 5-1

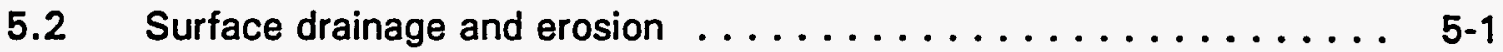

5.3 Seismicity ............................ $5-1$

5.4 Unexploited natural resources . . . . . . . . . . . . . . . 5-1

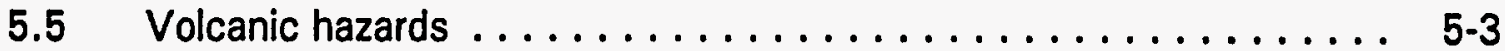

5.6 Potential future impact of sait-collapse phenomena . . . . . . . 5-3

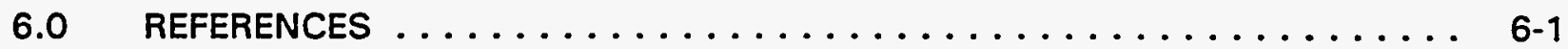

APPENDIX EVALUATION OF SUBSIDENCE POTENTIAL (BURRO CANYON) 
LIST OF FIGURES

Figure

Page

2.1 Physiographic map of the Colorado Plateau . . . . . . . . . . . . . 2-2

2.2 Regional physiographic features, Burro Canyon, Colorado, site . . . . . . 2-3

2.3 Regional stratigraphic section, Burro Canyon, Colorado . . . . . . . . . . 2-11

2.4 Structural and seismotectonic setting, Burro Canyon disposal site near

Slick Rock, Colorado . . . . . . . . . . . . . . . . . . . . . . . . 2-17

2.5 Regional geologic structure, Burro Canyon, Colorado, area . . . . . . . . . 2-19

2.6 Epicentral compilation of $M \geq 3$ earthquakes within $150 \mathrm{~km}$ (93 mi)

of the Burro Canyon disposal site near Slick Rock, Colorado . . . . . . . . . . 2-24

2.7 Areas of mineral resource development, Burro Canyon region near

Slick Rock, Colorado . . . . . . . . . . . . . . . . . . . . . . 2-37

2.8 Mining and claims areas, Burro Canyon disposal site near Slick Rock,

Colorado ............................. 2-38

3.1 Site geologic map, Burro Canyon disposal site near Slick Rock, Colorado . . . 3-2

3.2 Geology and topography, Burro Canyon disposal site near Slick Rock,

Colorado ................................ 3-3

3.3 Geologic cross section A-A', Burro Canyon disposal site near Slick Rock,

Colorado ................................ $3-4$

3.4 Geologic cross section B-B', Burro Canyon disposal site near Slick Rock,

Colorado ................................ 3-5

3.5 Geologic cross section C-C', Burro Canyon disposal site near Slick Rock, Colorado .............................. 3-6

3.6 Geologic cross section $D-D^{\prime}$, Burro Canyon disposal site near Slick Rock, Colorado .............................. 3-7

3.7 Surficial geology, Burro Canyon area near Slick Rock, Colorado . . . . . . . . 3-10

3.8 Drainage systems, Burro Canyon area near Slick Rock, Colorado . . . . . . . 3-11

Plate 2.1 Fault and epicenter map, Burro Canyon site, Colorado 


\section{LIST OF TABLES}

\section{Table}

Page

2.1 Stratigraphic units in the Burro Canyon, Colorado, disposal site area . . . . 2-12

2.2 Seismotectonic characteristics of the Colorado Plateau and adjacent provinces . . . . . . . . . . . . . . . . . . . . . . . 2-26

2.3 Probabilistic estimates of maximum acceleration, velocity, and intensity in the Burro Canyon, Colorado, site area . . . . . . . . . . . . . . 2-27

2.4 Earthquakes of $M \geq 3.0$ within $150 \mathrm{~km}$ of the Burro Canyon, Colorado, disposal site ................................ 2-31

2.5 Estimated maximum peak horizontal ground acceleration from MEs on regional seismotectonic features, Burro Canyon Colorado, site area . . . . 2-35

4.1 Summary of analysis of mapped faults and lineaments within a $65-\mathrm{km}$ radius of the Burro Canyon, Colorado, disposal site . . . . . . . . . . 4-4 


\section{LIST OF ACRONYMS}

$\begin{array}{ll}\text { ATC } & \text { Applied Technology Council } \\ \text { BLM } & \text { Bureau of Land Management } \\ \text { DOE } & \text { U.S. Department of Energy } \\ \text { EPA } & \text { U.S. Environmental Protection Agency } \\ \text { FE } & \text { floating earthquake } \\ \text { LANDSAT } & \text { land satellite } \\ \text { LSA } & \text { low-sun-angle } \\ M_{b} & \text { body-wave magnitude } \\ M_{L} & \text { local magnitude } \\ \text { MS } & \text { surface-wave magnitude } \\ \text { ME } & \text { maximum earthquake } \\ \text { MMI } & \text { Modified Mercalli Intensity } \\ \text { MSL } & \text { mean sea level } \\ \text { NGDC } & \text { National Geophysical Data Center } \\ \text { NOAA } & \text { National Oceanic and Atmospheric Administration } \\ \text { NRC } & \text { U.S. Nuclear Regulatory Commission } \\ \text { PGA } & \text { peak ground acceleration } \\ \text { PHA } & \text { peak horizontal acceleration } \\ \text { PHV } & \text { peak horizontal velocity } \\ \text { RAC } & \text { Remedial Action Contractor } \\ \text { RAP } & \text { remedial action plan } \\ \text { TAC } & \text { Technical Assistance Contractor } \\ \text { TAD } & \text { Technical Approach Document } \\ \text { UMTRA } & \text { Uranium Mill Tailings Remedial Action } \\ \text { UPDCC } & \text { UMTRA Project Document Control Center } \\ \text { USGS } & \text { U.S. Geological Survey }\end{array}$




\subsection{INTRODUCTION}

\section{$1.1 \quad$ CRITERIA AND DEFINITIONS}

This section presents definitions and criteria used in conducting site hazard evaluations. They are presented to standardize usage throughout this document and are pertinent to the seismic hazard evaluation because of the wide range of interpretation or usages of certain seismological terms.

Design life. As specified by the U.S. Environmental Protection Agency (EPA) standards for remedial action at inactive uranium processing sites 140 CFR Part 192), the controls implemented at Uranium Mill Tailings Remedial Action (UMTRA) Project sites must be effective for up to 1000 years, to the extent reasonably achievable, and in any case for at least 200 years. In assessing seismic and geomorphic hazards, the criteria established and the methodologies applied seek to ensure that the reclaimed wastes will not be damaged by earthquake ground motions, related ground rupture, or erosional encroachment for up to 1000 years.

Design earthquake. The magnitude of the earthquake that produces the largest on-site peak horizontal acceleration (PHA) is the magnitude of the design earthquake. This controlling earthquake could be the floating earthquake (FE) or an earthquake whose magnitude is derived from a relationship between capable fault rupture and/or fault length and maximum magnitude.

Capable fault. A capable fault is defined as a fault that has exhibited one or more of the following characteristics:

- Movement at or near the ground surface at least once within the past 35,000 years, or movement of a recurring nature within the past 500,000 years.

- Macroseismicity instrumentally determined with records of sufficient precision to demonstrate a direct relationship with the fault.

- A structural relationship to a capable fault such that movement on one fault could be reasonably expected to cause movement on the other.

This definition is essentially the one adopted by the U.S. Nuclear Regulatory Commission (NRC) for siting nuclear power plants (Appendix A of 10 CFR Part 100).

Acceleration. Acceleration is defined as the mean of the peaks of the two horizontal components of an accelerogram record. The exact term used is "peak horizontal acceleration." In a recent study by Keaton (1994a), the attenuation relationship of Campbell (1981), which was used for UMTRA Project seismic hazard analysis through 1993, was compared with more recent relationships to 
determine whether it is still applicable with the state-of-the-art approaches. Other comparative studies were consulted, such as Campbell (1984), Joyner and Boore (1988), and Johnson et al. (1992). Keaton interviewed several key authors and assessed comparisons of methodology and conservatism with more recent relationships that included Boore and Joyner (1994), Frankel et al. (1994), Boore et al. (1994), and Campbell and Bozorgnia (1994). These studies differ in philosophical approach; for example, Boore et al. believe the shape of the attenuation relationship is independent of earthquake magnitude, whereas Campbell and Bozorgnia believe shape is magnitude-dependent. The conclusion of this comparison, supported by attenuation curves of each study, is that Campbell's 1981 approach is reasonable and appropriate even though the database was smaller. However, because of the history of support for Campbell by the U.S. Department of Energy (DOE), NRC, and Technical Assistance Contractor (TAC), it is appropriate that DOE adopt the enhancements and refinements contained in Campbell and Bozorgnia (1994). Keaton's study is on file in the UMTRA Document Control Center (UPDCC), Albuquerque, New Mexico.

Magnitude and intensity. Magnitude was originally defined by C. F. Richter as the base-10 logarithm of amplitude of the largest deflection observed on a torsion seismograph located 62 miles (mi) (100 kilometers [km]) from the epicenter. This local magnitude $\left(\mathrm{M}_{L}\right)$ value may not be the same as the body-wave $\left(M_{b}\right)$ and surface-wave $\left(M_{S}\right)$ magnitudes derived from measurements at teleseismic distances. Unless specified otherwise, Richter magnitude values are used in the seismic hazard evaluations.

Intensity is the index of the effects of an earthquake on the human population and made-made structures and is based on the Modified Mercalli Intensity (MMI) scale.

Because preinstrumental earthquakes are reported in intensity and more recent instrumental records are in magnitude, several equations have been proposed to relate these values. Unless otherwise specified, the following relationship developed by Gutenberg and Richter (1956) is applied.

$$
M=1+2 / 3 I_{0}
$$

where $M=$ magnitude in the Richter scale and $\mathrm{l}_{0}=\mathrm{MMI}$ in the epicenter area.

It is generally acknowledged that some confusion prevails in the use of various magnitude scales in the engineering and seismic literature. This confusion results from the lack of instrumental data in places such as the Colorado Plateau, limitations of the instruments themselves, the complex nature of seismic phenomena, and the fact that different scales are used for different purposes. The $M_{L}$ scale is used primarily in the western United States and the $M_{b}$ scale is considered more appropriate for the central and eastern United States. This is because the $M_{L}$ and $M_{b}$ scales are proportional to the ground motion amplitudes near one second period, which is the part of the ground 
motion spectrum of most interest to engineers (Nuttli and Herrmann, 1982). Magnitudes of design earthquakes for the UMTRA Project will be specified in terms $M_{L}$ for earthquakes of less than magnitude 6.5. Magnitudes above 6.5 sometimes are expressed as $M_{S}$, depending on the method used to calculate maximum earthquakes (ME).

The fault length versus magnitude relationship is taken from Bonilla et al. (1984), who compiled statistical relationships of surface rupture length and fault displacement to $\mathrm{M}_{\mathrm{S}}$. The following relationship of Bonilla et al. (1984) was used for plate interiors:

$$
M_{S}=6.02+0.729 \log L
$$

where $L=$ mapped fault rupture length.

Maximum earthquake. An ME is the earthquake associated with specific seismotectonic source areas or provinces that would cause the most severe vibratory ground motion or foundation dislocation capable of being produced at the site under the currently known tectonic framework. It is typically adopted from published literature and based on all known regional and local geological and seismological data.

Floating earthquake. An FE is the largest earthquake within a specific seismotectonic province that is not associated with a known tectonic structure. Before assigning the FE magnitude, the earthquake history and tectonic character of the province are analyzed.

FE magnitude is an estimate of the threshold magnitude at which ground breakage occurs and, thus, a maximum magnitude for the FE. An event of larger magnitude will produce ground breakage and, by the above definition, is not an FE. The conservative value of $M_{L}=6.2$ as the threshold magnitude is based on Krinitzsky and Chang (1975), DOE (1985), and Keaton (1994b); it is applicable to the western United States plate interior. The FE is located at a radial distance of $9.3 \mathrm{mi}(15 \mathrm{~km})$ from the site.

The adaptation of the magnitude $6.2 \mathrm{FE}$ and a radial distance of $9.3 \mathrm{mi}(15 \mathrm{~km})$ for this event was the result of a multilateral decision of a committee of the NRC, DOE, TAC, and the Remedial Action Contractor (RAC) to provide a standard for the majority of UMTRA Project sites, which are primarily in the Colorado Plateau and the Western Interior Plate (DOE, 1985). This decision followed the examples of other NRC offices and was reaffirmed by Keaton (1994b).

The 9.3-mi $(15-\mathrm{km})$ distance is significant because it is based on the distance of transition from near-field to far-field that is a function of magnitude and because it is used within the nuclear power generation industry. Where earthquake 
spectra have not been developed at critical nuclear facilities, the $15 \mathrm{~km}$ came to be used as a typical or average source-to-site distance (Keaton, 1994b).

At average source distances closer than $15 \mathrm{~km}$, the parameters affecting ground motion, direction of propagation, and duration can vary greatly, so the PHA and peak horizontal velocity (PHV) become independent of earthquake magnitude (Campbell, 1984).

In a DOE white paper, Keaton assessed the technical merits of the distance and magnitude for FEs, concluding the use of 6.2 magnitude as a threshold event for ground rupture is reasonable and the $15-\mathrm{km}$ radial distance is appropriate for the Colorado Plateau (Keaton, 1994b). This assessment is a literature review and includes interviews with technical experts. The U.S. Bureau of Reclamation considers an annual frequency of 0.00002 an acceptable risk for a background earthquake, and the resulting plot is on the order of $15-\mathrm{km}$ site-to-source distance for design of dam facilities in the Colorado Plateau (Keaton, 1994b). Studies by dePolo (1994) and Arabasz et al. (1992) and graphical comparison of rupturing versus nonrupturing earthquakes led Keaton (1994b) to conclude that the average threshold magnitude for the Basin and Range province was magnitude 6.2.

Seismic records for the Colorado Plateau show the largest historical earthquake is less than magnitude 6.0, with no evidence of associated surface faulting. Considering the estimated magnitude (Algermissen et al., 1982) for the Colorado Plateau of $M=6.1$, the use of a magnitude 6.2 earthquake as background is reasonable. Keaton (1994b) is available in the UPDCC.

\subsection{SCOPE OF WORK}

The DOE conducted detailed investigations of the geologic, geomorphic, and seismic conditions in the Burro Canyon area to determine if it is an appropriate disposal site for the tailings from two processing sites in the Slick Rock, Colorado, area. These studies were designed to determine basic site characterization and identify potential geologic hazards that could affect long-term site stability. Subsequent engineering studies (e.g., analyses of hydrologic and liquefaction hazards) used the data developed in these studies. The geomorphic analysis was employed to design effective erosion protection methods. Studies of the regional and local seismotectonic setting, which included a detailed search for possible capable faults within a $65-\mathrm{km}$ radius of the site, provided the basis for seismic design parameters.

The scope of work performed included the following:

- Compilation and analysis of previous published and unpublished geologic literature and mapping.

- Review of historical and instrumental earthquake data. 
- Review of site-specific UMTRA Project subsurface geologic data, including logs of exploratory boreholes advanced in the site area.

- Photogeologic interpretations of existing land satellite (LANDSAT) and conventional aerial photography.

- Low-sun-angle (LSA) aerial reconnaissance of the site region.

- Ground reconnaissance and mapping of the site region.

The site and the area within a radius of $1 \mathrm{mi}(2 \mathrm{~km})$ are referred to here as the "site area." The surrounding region, encompassing west-central Colorado and adjoining eastern Utah, is referred to as the "site region." The following topics are relevant to the stabilization of mill tailings at the Slick Rock disposal site:

- Characterization of the regional geologic setting and its correlation to site geology.

- Identification of geomorphic hazards and suggestions for mitigative measures.

- Seismotectonic evaluation to provide initial design earthquake and acceleration parameters. Subsequent engineering analyses to fully assess the liquefaction potential and slope stability.

- On-site fault rupture potential.

- Potential for damage by earthquake-induced natural slope failure.

- Potential impact of geothermal and volcanic activity, subsidence due to tectonic causes, and reservoir-induced seismicity.

- Analysis of mineral resource potential and the possible impact on site stability of future mineral resource development.

\section{Geomorphic evaluation}

The purpose of the geomorphic evaluation of UMTRA Project sites is to characterize the current geomorphic conditions and to assess the impact of geomorphic processes on the long-term stability of the uranium mill tailings piles. These evaluations are restricted to the assessment of natural geomorphic processes and the geomorphic effects of past land-use activities, but do not address future human activities or potential hazards related to site hydrology.

The methodologies and criteria presented by Schumm and Chorley (1983) and Nelson et al. (1983) used as guides for the geomorphological investigations of UMTRA Project sites. Schumm and Chorley (1983) give detailed theoretical discussion of geomorphic processes that may affect a tailings site. Nelson et al. 


\subsection{REGIONAL GEOLOGY}

\subsection{REGIONAL PHYSIOGRAPHY}

The Burro Canyon disposal site is in the northeastern part of the Colorado Plateau physiographic province, near its boundary with the Southern Rocky Mountains province (Figure 2.1). The site area lies in the Canyon Lands section of the Colorado Plateau province. The eastern part of the Canyon Lands section, which includes the site, is characterized by large-scale folds, unwarped plateaus, lava-capped mesas, deep and narrow river canyons, and laccolithic mountains (Hunt, 1974). South of and parallel to the Uncompahgre Plateau is the northwest-trending, folded belt of the broad Paradox Basin. Principal physiographic elements within the study area include the Dolores River valley; the San Juan River valley; the La Sal, Abajo, and San Miguel Mountains; and the Uncompahgre Plateau. Collapsed salt anticline features include the Paradox Valley, Libson Valley, Gypsum Valley, and Spanish Valley.

South of the site, a high plain rises gradually from the southwest to the gently arched Dolores anticline. At the site area, the land surface drops to a relatively low elevation along the synclinal Disappointment Valley. The land surface just west of the site area is deeply incised by the antecedent (or superimposed), generally north-flowing Dolores River, and by tributary canyons. Figure 2.2 shows the physiographic features of the Dolores River drainage basin.

The Burro Canyon disposal site lies in the folded belt of the Paradox Basin between the Uncompahgre Plateau and the uplifted laccolith mountains of the La Sal and Abajo Mountains to the west. The La Sal Mountains rise to elevations of about $13,000 \mathrm{ft}(4000 \mathrm{~m})$. East of this range, the land surface slopes gradually toward the deeply entrenched Dolores River. Uplift of the region in the late Tertiary resulted in downcutting of the river from the upper plateau elevation of about $8000 \mathrm{ft}(2400 \mathrm{~m})$ to the current river surface elevation of about $5500 \mathrm{ft}(1700 \mathrm{~m})$. In the folded belt of the Paradox Basin, sedimentary strata of Mesozoic age are folded into a series of broad, northwest-trending, faulted anticlines and synclines. The salt-cored, collapsed anticlinal valleys, including Disappointment Valley, are bordered by faulted, parallel ridges and alternate with broad, flat synclinal valleys. Valley elevations in the site area range from 5000 to $6000 \mathrm{ft}(1500$ to $1800 \mathrm{~m})$ and ridges of upturned sedimentary rocks rise to elevations of about $7000 \mathrm{ft}(2100 \mathrm{~m})$. The salt-cored structures occupy an area from the edge of the Dolores River near Slick Rock northeastward to the edge of the uplifted Uncompahgre Plateau.

\section{Regional geomorphology}

Geomorphic features and Quaternary deposits in the Slick Rock area reflect the interaction of geologic and climatic variables. The physiography, topography, and Quaternary deposit record attest to the predominance of fluvial and eolian erosion as well as mass movement processes operating in a semiarid to 


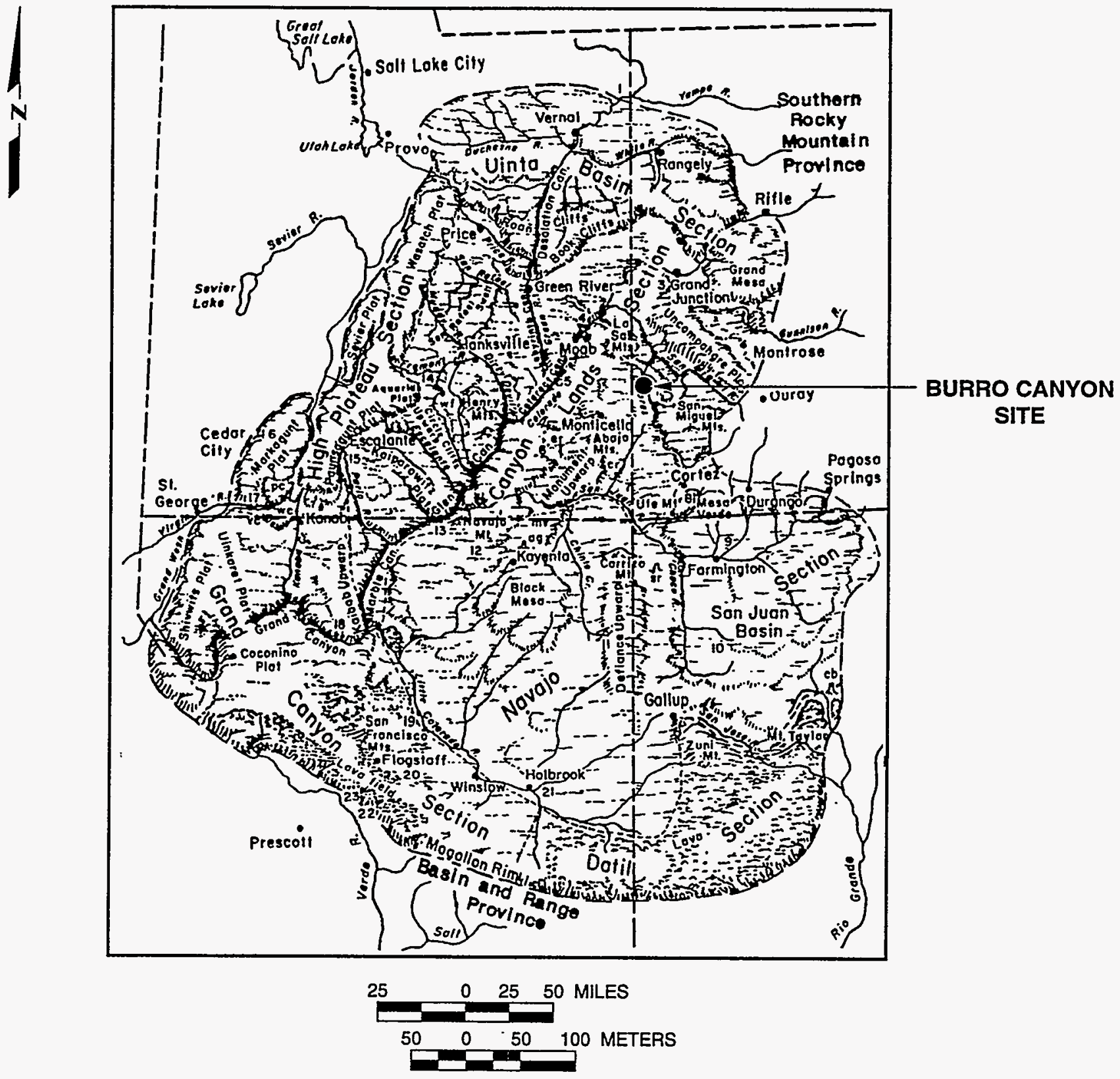

\section{National Parks And Monuments}

1. Dinosaur Nat. Mon.

2. Black Canyon of the

Gunnison Nat. Mon.

3. Colorado Nat. Mon.

4. Arches Nat. Mon.

5. Canyonlands Nat. Mon.

6. Natural Bridges Nat. Mon.

7. Hovenweep Nat. Mon.

8. Mesaverde Nat. Park

9. Aztec Ruins Nat. Mon.

10. Chaco Canyon Nat. Mon.

11. Canyon De Chelly Nat. Mon.

12. Navajo Nat. Mon.

(Betatakin and Kiet Seel)
13. Rainbow Bridge Nat. Mon.

14. Capital Reef Nat. Mon.

15. Bryce Canyon Nat. Park

16. Cedar Breaks Nat. Mon.

17. Zion Nat. Park

18. Grand Canyon Nat. Park

19. Wupatki and Sunset Crater Nat. Mons.

20. Walnut Canyon Nat. Mon.

21. Petrified Desert Nat. Mon. Painted Desert Nat. Mon.

22. Montezuma Castle Nat. Mon.

23. Tuzigoot Nat. Mon
Escarpments at South End of High Plateaus

pc Pink Cliffs

wc White Cliffs

vc Vermilion Cliffs

\section{Other Prominent Features}

wf Waterpocket Fold

er Elk Ridge

cr Comb Ridge

mv Monument Valley

ag Agathla Peak

sr Shiprock

cb Cabezon Peak 


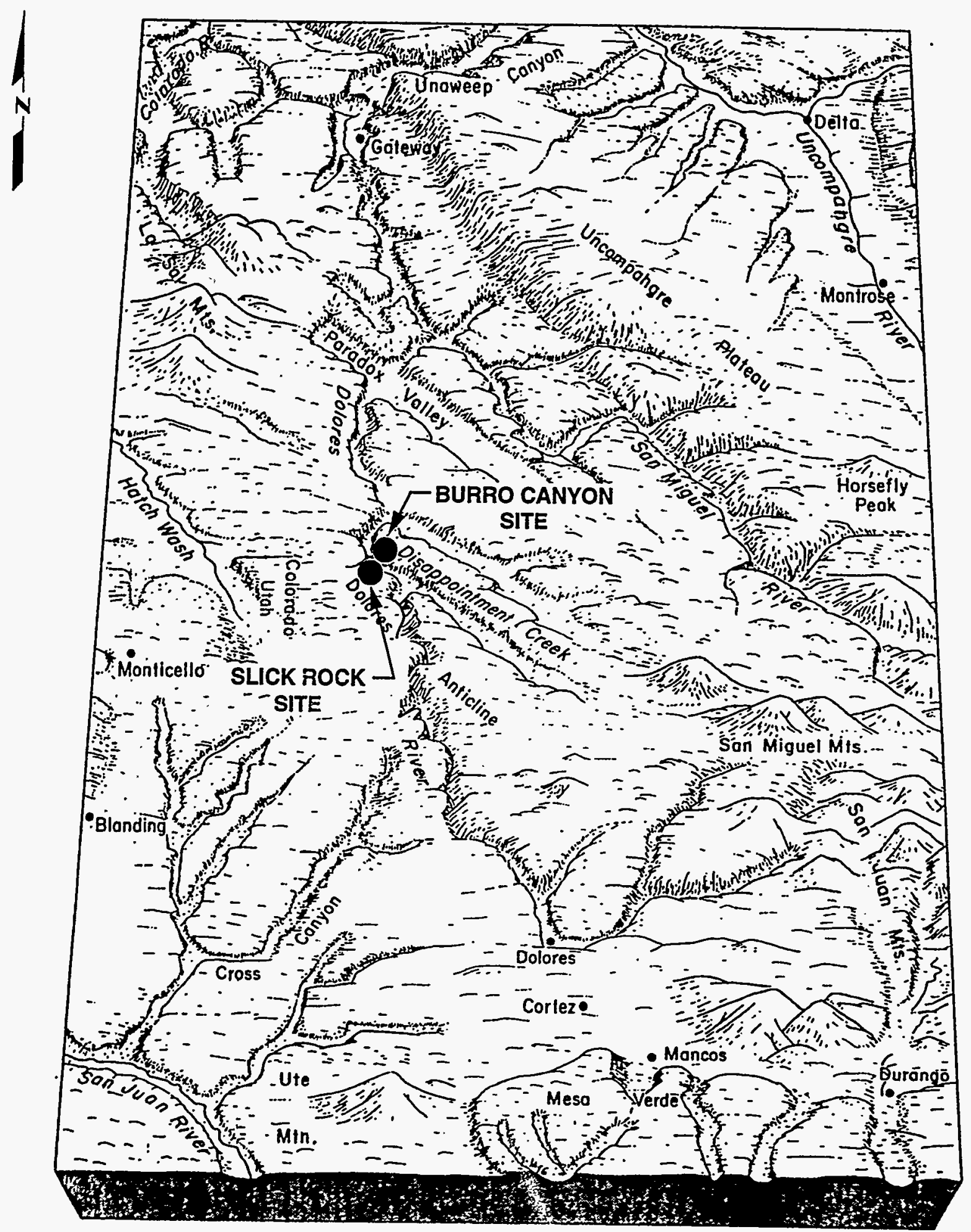

FIGURE 2.2

REGIONAL PHYSIOGRAPHIC FEATURES BURRO CANYON, COLORADO, SITE 
temperate climate during Quaternary time. Glacial deposits on high-elevation mountains in the region indicate climatic fluctuations.

Numerous geologists have investigated the development of drainage patterns, terraces, pediments, and glacial moraines in the site region. The following discussion is excerpted from articles by Hunt (1956), Lohman (1981; 1965), Yeend (1969), Sinnock (1981a; 1981b; 1978), and Shawe et al. (1968).

Since about 10,000 years ago, fluvial erosion processes have been the dominant geomorphic force in the region. Late Cenozoic uplift of the Colorado Plateau has been the major driving force in the evolution of the landscape, triggering landscape rejuvenation, stream channel incision, and removal of massive amounts of sedimentary bedrock. At least $5000 \mathrm{ft}(1520 \mathrm{~m})$ of regional downcutting of major rivers into sedimentary rocks of Early Tertiary to Late Cretaceous age has occurred since uplift began (Yeend, 1969). Downcutting has produced long steep slopes, oversteepened cliffs, and narrow canyons. Extremes in elevation, slope exposure, and range of bedrock types allowed varied geologic processes to operate through time and produce very different effects on the landscape. Geomorphic studies in the Paradox Basin (W-C, 1982a) indicate regional incision processes were interrupted several times, during which landscape stability and stream aggradation allowed the deposition of Quaternary sediments and soil formation. These periods of landscape stability were probably caused by Quaternary climatic fluctuations.

In the site area, the regional base level for streams is the Colorado River, and incision has generally occurred in response to the lowering of the Colorado River. In the Paradox Basin area, erosion since Pliocene time has removed most of the Tertiary deposits and carved canyons up to $1500 \mathrm{ft}(460 \mathrm{~m})$ deep in the Mesozoic and Paleozoic rocks (W-C, 1982a). Integration of the present Colorado River drainage system occurred about 5 million years ago (McKee and McKee, 1972). Prior to the establishment of a through-going drainage system, the Paradox Basin probably was drained by local interior basin streams (Hunt, 1956).

Until perhaps Pliocene time, the Grand Junction area and adjacent parts of the Colorado Plateau were eroded by the ancestral Colorado River. The course of the Colorado River may have been established by the end of the Miocene. Differential uplift of the Uncompahgre Plateau was renewed during the Pliocene, causing major changes in the drainage patterns of the Colorado and Gunnison Rivers.

High-elevation gravel deposits of probable Early Pleistocene age overlie a deeply weathered Mancos Shale erosion surface east of the Dolores River (Shawe et al., 1968). Younger terrace gravel deposits of the Dolores River occur at levels 100,350 , and $650 \mathrm{ft}(30,110$, and $200 \mathrm{~m})$ below the Mancos Shale erosion surface, indicating rapid downcutting of the river since the Early Pleistocene (Shawe et al., 1968). At least some of this rapid downcutting was a reaction to structural upwarping of the district. 
The Dolores River traverses the site area from south to north in a deep canyon. Throughout most of its length, the canyon is markedly sinuous; with little doubt, the sinuousities are entrenched meanders inherited from the stream that flowed on the flat Miocene surface. Terraces at various levels in the canyon record periods during which lateral cutting locally predominated over downcutting.

Landforms indicative of glacial processes are present only in areas of the region higher than about $9000 \mathrm{ft}(3000 \mathrm{~m})$ above mean sea level (MSL). Glacial and periglacial activity occurred as recently as 10,000 years ago in the La Sal, Abajo, and San Juan Mountains. Significant amounts of sediment were added to drainages during glacial periods, resulting in cyclic deposition of gravel in valleys throughout the region (W-C, 1982a). Evidence of multiple Pleistocene glaciations is present in the La Sal Mountains (Richmond, 1962); however, the Abajo Mountains exhibit only periglacial processes (Witkind, 1964). No evidence is present to suggest glacial or periglacial processes occurred in areas at the elevation of the Slick Rock sites or the valleys of the Paradox Basin salt anticline area (W-C, 1982a).

Active geomorphic processes operating within the site region are fluvial erosion and deposition, eolian deposition, and mass movement. Fluvial processes are influenced by the semiarid and arid climate of most of the region. The high relief and sparse vegetation of the Paradox Basin result in rapid surface water runoff and active erosion. Sheetwash and the development of rills and gullies in fine-grained alluvium occur throughout the region. Within integrated drainage networks, sediment ultimately is transported to the Colorado River.

Mass movement processes are active on many slopes in the region. These processes occur as rock falls, debris slides and slumps, debris flows, and rock and soil creep. Rock falls from cliff walls and bedrock ledges are a dominant mechanism of cliff retreat and talus formation in the site area. Talus accumulations formed at the base of cliffs by rock falls usually weather rapidly and are removed by surface water flow and gravitational downslope movement. Falls involving sandstone units of the Burro Canyon Formation and the Salt Wash Member have occurred in the last few decades along steep cliffs next to the Dolores River (Shawe et al., 1968). The falls probably were initiated by erosional oversteepening of the less resistant strata underlying the sandstone blocks.

Extensive soil development studies have been conducted in the region at the La Sal Mountains (Richmond, 1962) and at Spanish Valley and the Paradox Basin (W-C, 1982a). Soils in the Paradox Basin area are developed on Pleistocene and Holocene deposits that have been subject to periods of accretion and erosion. Soil development correlations are thus difficult to achieve between discontinuous deposits. Soils developed in Pleistocene deposits commonly have well developed argillic horizons and distinct carbonate accumulations (W-C, 1982a). Carbonate soils occur on virtually all fluvial and eolian deposits at elevations below $7000 \mathrm{ft}(2100 \mathrm{~m})$. Soils developed on Holocene fine-grained deposits lack buried $A$ horizons and significant humic material in the 
surficial A horizons (W-C, 1982a). This suggests prevailing arid conditions during the last 10,000 years.

\section{Rates of denudation}

Due to the possible influence of long-term erosion processes on reclamation design, the rates of denudation and stream downcutting are discussed below. The rates of denudation are the rates at which a land surface is lowered by erosional processes.

The long-term predominance of erosional processes on the Colorado Plateau since the Late Tertiary time is evidenced by canyon topography and the great amounts of Tertiary and Cretaceous strata (3500 to 13,000 ft) (1100 to $4000 \mathrm{~m}$ ) that have been removed from much of the plateau surface. The relatively low strengths of Tertiary and Cretaceous bedrock facilitate the Late Tertiary and Quaternary erosion (Schumm and Chorley, 1966). Landscape features of the upper Colorado River Basin that suggest continuing erosion at a moderately rapid rate include high relief and deep, narrow, vertical-walled canyons; the absence of significant desert varnish on many cliff faces; the lack of talus accumulation below cliffs; and progressively less well-developed soils on successively lower terraces along streams (W-C, 1982a). Since Late Miocene time, erosion rates have been controlled by the Colorado River, which acts as the regional base level for streams. Potassium-argon dates of basalt flows indicate the Colorado River drainage above Grand Junction was established about 10 million years ago (Larson et al., 1975), whereas drainage integration through the Grand Canyon occurred by about 5 million years ago (McKee and McKee, 1972; Damon et al., 1978).

Relatively rapid erosion resulted from the combination of mechanically weak bedrock (Schumm and Chorley, 1966) and rapid tectonic uplift (Hunt, 1969; Luchitta, 1972; Larson et al., 1975). Broad spatial and temporal variations in erosion rates are due to differences in local rock type, changes in uplift rate, and climatic fluctuations.

Potential amounts of erosion at the site during the next 1000 years were estimated from several data types. Average stream channel incision and scarp retreat rates, calculated for periods on the order of millions of years, reflect the progressive development of major geomorphic features such as valleys and canyons. Modern denudation rates were calculated from sediment yield and reservoir sedimentation rates for large sections of the Colorado Plateau and for small test watersheds on the Mancos Shale. Future erosion rates at and near the site were estimated from local geomorphic features. These types of data represent greatly differing scales of space and time and, therefore, are not directly comparable. Moreover, each data type involves simplifications and measurement problems, so the resulting erosion rates are approximations. However, these data collectively indicate that future erosion at the site will be relatively low. 


\section{Regional erosion rates}

Average incision rates were calculated for most sites in the northeastern Colorado Plateau where radiometrically dated units are closely associated with stream channels. However, a few sites have minimum ages based on reversed paleomagnetic polarity (Johnson, 1982) or estimated age ranges based on geomorphic relationships. The maximum long-term incision rates are about $1 \mathrm{ft}$ $(0.3 \mathrm{~m}) / 1000$ years; however, most of the rates fall between 0.3 and $0.7 \mathrm{ft}$ $(0.1$ to $0.2 \mathrm{~m}) / 1000$ years. Some regional variation is apparent when rates for the same time interval are compared. The rates also are subject to change with time in a single area. For example (the Roaring Fork River), where the average incision rate varied as follows: $0.98 \mathrm{ft}(0.30 \mathrm{~m}) / 1000$ years $(10$ to 8 million years before present), $<0.1 \mathrm{ft}(0.03 \mathrm{~m}) / 1000$ years $(8$ to 1.5 million years before present), roughly $0.75 \mathrm{ft}(0.23 \mathrm{~m}) / 1000$ years $(1.5$ to 0.62 million years before present), and $0.52 \mathrm{ft}(0.16 \mathrm{~m}) / 1000$ years $(0.62$ million years before present to the present).

Channel incision rates also vary on shorter time scales, as indicated by pediments and terraces occurring at several levels above the Colorado, Gunnison, Uncompahgre, and Dolores Rivers (Lohman, 1965; Yeend, 1969; Sinnock, 1981a; 1978; Cole and Sexton, 1981; Shawe, 1968). These surfaces most likely formed during glacial intervals when larger sediment loads temporarily prevented channel incision. No incision rates were calculated from the heights of these surfaces because their ages are not well known. However, the presence of these surfaces indicates incision rates were more variable than the long-term averages indicate, and perhaps were several times higher during times of postglacial drainage adjustment.

Long-term average rates of scarp retreat are less well known than channel incision rates due to greater difficulties in dating, the episodic nature of the retreat (Schumm and Chorley, 1966), and local rate variations in salients, re-entrants, and tributary mouths (Haman, 1983). Most calculated rates are on the order of a few feet in 1000 years. An exceptionally rapid rate for the Book Cliffs at the northwestern end of the Uncompahgre Plateau, $74 \mathrm{ft}(23 \mathrm{~m}) / 1000$ years (Hunt, 1969), may be erroneously high. Valley widening at this location may have begun earlier than assumed along the tributary stream that later captured the Colorado River (Lohman, 1965).

Historic denudation rates for large parts of the Colorado Plateau are based on sediment yield and reservoir sedimentation measurements. Rates that include all components of sediment load (suspended, dissolved, and bed) mostly range from 0.3 to $0.8 \mathrm{ft}(0.09$ to $0.2 \mathrm{~m}) / 1000$ years. These rates are similar to long-term average channel incision rates, but the similarity must be partly fortuitous because the different time scales should reflect the controls of climate and tectonics in very different ways. 
Holocene erosion rates in the site area

Holocene erosion and incision rates have not been studied in the site area but relative rates can be inferred from studies conducted in nearby areas. Erodibility studies for similar rock types in the Paradox Basin area (W-C, 1982a) can be applied to the area.

Incision processes in the Paradox Basin probably involve periods of virtually no downcutting alternating with periods of active incision. Little bedrock incision appears to have occurred during the last 8000 to 10,000 years (W-C, 1982a). Exposures in the area show multiple cut-and-fill events, indicating successive cycles of erosion and deposition occurred during the past 10,000 years. Bedrock elevations in stream channels appear to have remained constant. Historic surface denudation rates range from 0.3 to $3.1 \mathrm{ft} 10.09$ to $0.94 \mathrm{~m}) / 1000$ years for lithologic units similar to those in the site area (W-C, 1982a). Geomorphic relationships within the Paradox Basin show the same range of erosion rates (W-C, 1982a). The rates show considerable variability based on local climatic conditions, different time intervals used in calculations, and variations in lithology, drainage basin area, topographic setting, and human activities. Within the site area, the most resistant rock types consist of silica-cemented sandstones (Burro Canyon Formation and Dakota Sandstone). The respective decreasingly resistant rock types are massive, friable sandstone with predominantly calcite cement (Entrada Sandstone, Navajo Sandstone, Wingate Sandstone, and Kayenta Formations); sandstone with interlayered siltstone (Salt Wash Member of the Morrison Formation and Summerville Formation); and siltstone with bentonitic mudstone (Brushy Basin Member of the Morrison Formation). Estimates of rates of scarp retreat in bedrock units in the site region range from 0.8 to $1.8 \mathrm{ft}(0.2$ to $0.55 \mathrm{~m}) / 1000$ years $(\mathrm{W}-\mathrm{C}, 1982 \mathrm{a})$ in formations similar to those at the site area. The considerable variations in rates throughout the area are due to differences in lithology. Incision and scarp retreat will occur most readily in those units composed of less resistant siltstone, mudstone, and calcite-cemented sandstone. Silica-cemented sandstone units will have low scarp recession rates. Bedrock incision rates and rates of scarp retreat may increase if changing climatic conditions result in lower mean annual temperatures and higher stream discharges.

\section{Climate and vegetation}

Annual precipitation at the site is 7 to 10 inches (200 to 250 millimeters [mm]) (NOAA, 1975) and reflects a seasonal variation; most rainfall occurs from June to October. Higher elevation areas outside the Dolores River valley average 15 to 20 inches (380 to $500 \mathrm{~mm}$ ) of annual precipitation (Shawe et al., 1968).

The area is in a transitional vegetation area characterized by sagebrush and other desert shrubs, small cacti, pinon-juniper woodland, and scattered pine trees (Shawe et al., 1968). Along the Dolores River and nearby springs, cottonwoods and yellow pines are common. Sagebrush dominates the lower slopes of the valley, while thick stands of pinon and juniper dominate the higher 
elevation mesas. Open plains at elevations of about $7000 \mathrm{ft}(2200 \mathrm{~m})$ are covered with sagebrush. Small stands of aspens and spruce trees grow at elevations higher than $8000 \mathrm{ft}(2400 \mathrm{~m})$.

\section{The Holocene climate}

Broad changes in postglacial climate have been documented for the western United States. Following a period of transitional climate, changes in average temperature for periods on the order of hundreds to thousands of years were most likely \pm 4 degrees Fahrenheit $\left({ }^{\circ} \mathrm{F}\right)\left( \pm 2\right.$ degrees Celsius $\left.\left[{ }^{\circ} \mathrm{C}\right]\right)$ (Knox, 1983). However, few of the paleoenvironmental data available were used to derive quantitative estimates of climate change.

The time following the last glaciation has been divided into three climatic intervals:

- A transitional period from 14,000 to 7000 years ago.

- A slightly warmer period ending around 4000 years ago.

- A slightly cooler period continuing to the present.

Evidence for the Middle Holocene warm period is abundant in surrounding areas but is poor in Colorado, perhaps because the sites studied are insensitive to small climatic changes (Baker, 1983).

Short periods of greater effective moisture during the Holocene are documented in parts of the southwestern United States. These studies associate more pluvial conditions with intense, warm-season precipitation, triggering major periods of landscape instability, erosion, and sedimentation (Gile et al., 1981). Observation in the Paradox Basin (W-C, 1982a) indicates the valley fill was removed and redeposited during multiple cut-and-fill episodes. Episodic fluctuations in Holcene surficial geologic processes in the Colorado Plateau area are indicated by periodic eolian deposition during neoglacial interstadices of the last 6000 years (Curry, 1976) and by incipient soil development on buried, fine-grained fluvial deposits.

No data on Holcene climates are available for the Slick Rock site area, but inferences may be drawn from pollen studies in surrounding areas

(Baker, 1983). The closest and possibly most similar site, Alkali Basin (Markgraf and Scott, 1981), is northwest of Gunnison, Colorado, on the flank of the West Elk Mountains. At an elevation of $9000 \mathrm{ft}(2700 \mathrm{~m})$, this site was not glaciated. The period from 10,000 to 4000 years is interpreted to be about $1.5^{\circ} \mathrm{F}\left(1^{\circ} \mathrm{C}\right)$ cooler and 50 percent more moist than the period from about 4000 years to the present.

Tree-ring studies (Fritts, 1971) show significant climate variability during the last few centuries in periods ranging from a few years to a few decades and longer. Although shorter, historic records corroborate these short-term fluctuations (Bradley, 1976). 
Relative changes in effective moisture for the Colorado Plateau were interpreted for the last several centuries from tree-ring data (Stockton and Jacoby, 1976). This study included data from several sites in western Colorado. A synthetic hydrograph, developed for the discharge of the San Juan River near Bluff, Utah, integrates local variations in moisture over a large area. An important aspect of this hydrograph is its short-term variability, which may illustrate the potential variability in the site area. The strongest periodicities in the hydrograph were 50 and 5 years, but weaker periodicities of 3 and 2 years also occurred.

Historical climatic records for several stations in the San Juan Mountains were analyzed in detail (Bradley and Barry, 1976). The resulting trends indicate the general magnitude of short-term variations that could be expected in the site area. At the most carefully studied station (Durango, from 1900 to 1970), the 9-year weighted-mean temperature varied by about $3.3^{\circ} \mathrm{F}\left(1.8^{\circ} \mathrm{C}\right)$. In contrast, the 9-year weighted-mean precipitation varied by a factor of 1.7 , from 13.5 to 23 inches ( 343 to $580 \mathrm{~mm}$ ); the annual mean precipitation varied by a factor of more than 2. Variations also occurred in the seasonal distribution of temperature and precipitation and in the frequency and size of rainfall events.

General trends in temperature indicated regional cooling from the late 1860 s until about 1930 , followed by regional warming. General trends in precipitation were roughly inverse to those in temperature but were much less consistent.

For the next few hundred to a thousand years, average temperature and precipitation most likely will fluctuate within the same ranges as during the recent past.

\subsection{STRATIGRAPHIC SETTING}

Stratigraphic units underlying the Burro Canyon site region range from a Precambrian basement complex to a thick sequence of marine and continental rocks of Cambrian to Cretaceous age, overlain by igneous rocks of Tertiary age and unconsolidated Quaternary deposits. The combined thickness of sedimentary rocks in the region is about $13,000 \mathrm{ft}(4000 \mathrm{~m})$ and, prior to erosion in the late Tertiary and Quaternary, may have been as much as $18,000 \mathrm{ft}(5500 \mathrm{~m})$ (Shawe et al:, 1968). The sedimentary units in the site region are folded into broad, parallel, northwest-trending anticlines and synclines intruded by evaporite rocks into the axial parts of the anticlines. The west and south parts of the region contain localized laccolith igneous centers. Figure 2.3 shows a generalized composite stratigraphic section of the site region. Table 2.1 describes the stratigraphic units cropping out in the immediate site area.

Paleozoic sedimentary rocks in the region are underlain by a Precambrian igneous and metamorphic basement complex, generally at depths of 2000 to $4000 \mathrm{ft}(600$ to $1200 \mathrm{~m}$ ) below sea level (Shawe et al., 1968). The Paleozoic 


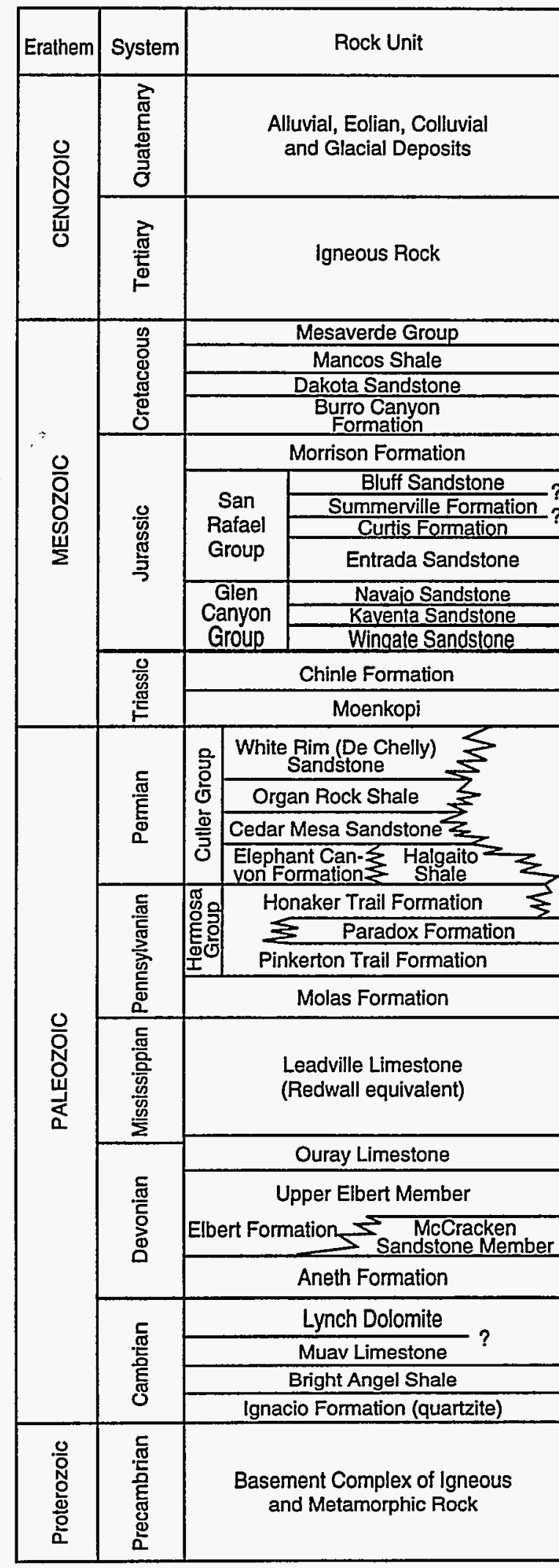

\section{BURRO CANYON} DISPOSAL SITE

\section{SLICK ROCK} PROCESSING SITE

FIGURE 2.3

REGIONAL STRATIGRAPHIC SECTION BURRO CANYON, COLORADO 
Table 2.1 Stratigraphic units in the Burro Canyon, Colorado, disposal site area

\begin{tabular}{|c|c|c|c|}
\hline Age & Unit & $\begin{array}{c}\text { Approximate } \\
\text { thickness in site area } \\
\text { [ft }(\mathrm{m})]\end{array}$ & Description \\
\hline Quaternary & $\begin{array}{l}\text { Quaternary } \\
\text { deposits }\end{array}$ & Varying thickness & $\begin{array}{l}\text { Consist of landslide deposits, terrace gravels, alluvial } \\
\text { fan deposits, and minor soil, loess, alluvium, colluvium, } \\
\text { and talus. }\end{array}$ \\
\hline Upper Cretaceous & Mancos Shale & $\begin{array}{l}0-860 \mathrm{ft} \\
(0-260 \mathrm{~m})\end{array}$ & $\begin{array}{l}\text { Dark gray carbonacous calcareous shale with abundant } \\
\text { silt and sand. Remnants of the formation are found in } \\
\text { the lower portion of Disappointment Valley. }\end{array}$ \\
\hline Lower and Upper Cretaceous & Dakota Sandstone & $130 \mathrm{ft}(40 \mathrm{~m})$ & $\begin{array}{l}\text { Light brown to dark gray, thin-bedded to massive, } \\
\text { cross-bedded, arenaceous sandstone with common } \\
\text { carbonaceous material and gray and brown } \\
\text { conglomerate with chert, sandstone, and quartzite } \\
\text { pebbles. Thin; evenly-bedded carbonaceous shale and } \\
\text { mudstone and thin coal layers occur between the upper } \\
\text { and lower sandstone units. In the site area, the lower } \\
\text { contact is marked by a carbonaceous shale that is in } \\
\text { conformable contact with the Burro Canyon Formation. } \\
\text { At other locations there is an unconformable contact. }\end{array}$ \\
\hline Lower Cretaceous & $\begin{array}{l}\text { Burro Canyon } \\
\text { Formation }\end{array}$ & $400 \mathrm{ft}(120 \mathrm{~m})$ & $\begin{array}{l}\text { White, gray, red, and light brown fluvial sandstone and } \\
\text { conglomerate interbedded with green and purple } \\
\text { lacustrine siltstone, shale, and mudstone. Forms cliffs } \\
\text { and steep, even slopes. }\end{array}$ \\
\hline Upper Jurassic & Morrison Formation & $750 \mathrm{ft}(230 \mathrm{~m})$ & $\begin{array}{l}\text { Variegated fluvial channel and floodplain deposits of } \\
\text { shale, mudstone, and sandstone with thin limestone and } \\
\text { conglomerate lenses. Divided into the Brushy Basin } \\
\text { Shale Member and the Salt Wash Sandstone Member. } \\
\text { Brushy Basin Shale Member: Gray, pale green-red, and } \\
\text { light purple bentonitic mudstone, fluvial sandstone, and } \\
\text { conglomerate lenses. Mudstones are evenly bedded } \\
\text { and sandstone lenses are cross-bedded. }\end{array}$ \\
\hline
\end{tabular}




\begin{tabular}{|c|c|c|c|c|}
\hline 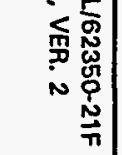 & Age & Unit & $\begin{array}{c}\text { Approximate } \\
\text { thickness in site area } \\
\text { [ft (m)] }\end{array}$ & Description \\
\hline & & & & $\begin{array}{l}\text { Salt Wash Sandstone Member: Light buff to light reddish-brown } \\
\text { lenticular fluvial sandstone and cross-bedded sandstone } \\
\text { intercalated with reddish-brown floodplain mudstone layers and } \\
\text { thin, discontinuous limestone beds near base. Generally forms a } \\
\text { transitional contact with the underlying Summerville Formation. } \\
\text { Minor uranium deposits occur in the lower part of the Salt Wash } \\
\text { Member. The upper part of the member contains the major } \\
\text { uranium-vanadium deposits of the region. }\end{array}$ \\
\hline 岕 & Upper Jurassic & 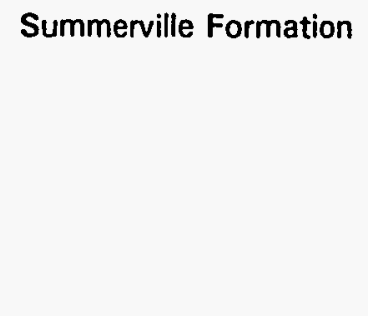 & $120 \mathrm{ft}(37 \mathrm{~m})$ & $\begin{array}{l}\text { Greenish-gray argillaceous, horizontally bedded sandy siltstone and } \\
\text { mudstone changing to a reddish-brown, horizontally bedded sandy } \\
\text { siltstone and mudstone below a thin marker bed of reddish-brown } \\
\text { to brown very fine-grained silty sandstone with oscillatory ripple } \\
\text { marks. Lower part of the formation consists of reddish-brown and } \\
\text { greenish-gray, very fine-grained laminated sandstone interbedded } \\
\text { with thin layers of claystone, mudstone, or siltstone. Base of unit } \\
\text { is transitional to the underlying Entrada Sandstone. }\end{array}$ \\
\hline & Middle Jurassic & $\begin{array}{l}\text { Entrada Sandstone: } \\
\text { Slick Rock and Dewey } \\
\text { Bridge Members }\end{array}$ & $\begin{array}{l}90-155 \mathrm{ft} \\
(30-47.2 \mathrm{~m})\end{array}$ & $\begin{array}{l}\text { Buff, brown, and reddish-brown, fine-grained quartzose sandstone } \\
\text { and reddish-brown clayey siltstone with a localized chert pebble } \\
\text { conglomerate at the base. Divided into the fine-grained, } \\
\text { horizontally bedded to massively cross-bedded sandstone of the } \\
\text { Slick Rock Member at the top; and the clayey siltstone and sand- } \\
\text { stone of the Dewey Bridge Member at the base. The upper } \\
\text { sandstone unit forms cliffs and the lower siltstone unit weathers to } \\
\text { low mounds. Forms a disconformable contact with the underlying } \\
\text { Navajo Sandstone. }\end{array}$ \\
\hline
\end{tabular}




\begin{tabular}{|c|c|c|c|}
\hline Age & Unit & $\begin{array}{l}\text { Approximate thickness } \\
\text { in site area } \\
{[\mathrm{ft}(\mathrm{m})]}\end{array}$ & Description \\
\hline Lower Jurassic(?) & Navajo Formation & $100 \mathrm{ft}(30 \mathrm{~m})$ & $\begin{array}{l}\text { Buff and reddish-brown, fine-grained eolian sandstone with large } \\
\text { scale tangential cross beds. Forms sheer cliffs. Contact with the } \\
\text { underlying Kayenta Formation is irregular. }\end{array}$ \\
\hline Lower Jurassic(?) & Kayenta Formation & $180 \mathrm{ft}(55 \mathrm{~m})$ & $\begin{array}{l}\text { Reddish-brown to purple-gray, thin-bedded to cross-bedded fine- to } \\
\text { coarse-grained sandstone, shaly sandstone, shale, and pebble } \\
\text { conglomerate. Forms steep, closely-spaced ledges and occasional } \\
\text { sheer cliffs. }\end{array}$ \\
\hline Lower Jurassic(?) & Wingate Sandstone & $250 \mathrm{ft}(76 \mathrm{~m})$ & $\begin{array}{l}\text { Reddish-brown, orange-brown, buff, fine-grained, massive } \\
\text { thick-bedded, cross-bedded eolian sandstone. Forms prominent, } \\
\text { vertical cliffs with red and black desert varnish on weathered } \\
\text { surfaces. }\end{array}$ \\
\hline \multirow[t]{3}{*}{ Upper Triassic } & Chinle Formation & $550 \mathrm{ft}(170 \mathrm{~m})$ & $\begin{array}{l}\text { Terrestrial red to orange-red siltstone with interbedded lenses of } \\
\text { red sandstone, shale, and limestone-pebble and clay-pellet } \\
\text { conglomerate. Lenses of quartz-pebble conglomerate and grit at } \\
\text { base. Rests unconformably on Cutler Formation rocks. Divided } \\
\text { into Church Rock, Petrified Forest, and Moss Back Members. } \\
\text { Contains uranium and vanadium. }\end{array}$ \\
\hline & & & $\begin{array}{l}\text { Church Rock Member: Mainly reddish-brown, purple, and gray } \\
\text { shaly siltstone, mudstone, and sandstone with thin layers and } \\
\text { lenses of cross-bedded to horizontally-layered pebble conglomerate. } \\
\text { Petrified Forest Member: Grayish-green mudstone, siltstone, and } \\
\text { shale with minor reddish-brown mudstone and greenish-gray } \\
\text { sandstone and conglomerate. In places, limestone and mudstone } \\
\text { pebble conglomerate is cross-bedded. }\end{array}$ \\
\hline & & & $\begin{array}{l}\text { Moss Back Member: Greenish-gray limey arkosic and quartzose } \\
\text { sandstone and conglomerate with minor beds of greenish-gray to } \\
\text { reddish-brown mudstone, siltstone, and shale. }\end{array}$ \\
\hline
\end{tabular}


Table 2.1 Stratigraphic units in the Burro Canyon, Colorado, disposal site area (Concluded)

\begin{tabular}{cccc}
\hline Age & Unit & $\begin{array}{c}\text { Approximate thickness } \\
\text { in site area } \\
{[\mathrm{ft}(\mathrm{m})]}\end{array}$ & \multicolumn{1}{c}{ Description } \\
\hline Permian & Cutler Formation & $3,000 \mathrm{ft}(900 \mathrm{~m})$ & $\begin{array}{l}\text { Cross- and horizontally-bedded, coarse-grained, reddish-brown to } \\
\text { brown arkosic sandstone forming a prominent ledge. Contains } \\
\text { siltstone, mudstone, and shale in lower part of unit. Transitional } \\
\text { between marine sediments to the west and terrestrial sediments to } \\
\text { the east. Upper } 240 \mathrm{ft} \text { (73 } \mathrm{m}) \text { exposed in Dolores River Canyon. }\end{array}$ \\
\hline
\end{tabular}

Adapted from Shawe et al. (1968). 
rocks are composed of $5000 \mathrm{ft}(1500 \mathrm{~m})$ or more of marine carbonates and evaporites interbedded with clastic sedimentary units.

In the subsurface, the most significant Paleozoic formation is the extremely thick deposit of the Hermosa Group, including the Paradox Salt Formation. This Pennsylvanian age deposit consists of evaporite deposits of halite, gypsum, and phosphate minerals. Its depositional extent determines the area of the Paradox Basin and resulted in the formation of the salt core anticlines of the region.

Outcropping units include the upper part of the Cutler Formation of Permian age; the Chinle Formation and Wingate Sandstone of Triassic age; the Kayenta Formation of Triassic age; the Navajo Sandstone of Triassic and Jurassic age; the Entrada Sandstone, Summerville Formation, Junction Creek Sandstone, and Morrison Formation of Jurassic age; and the Burro Canyon Formation, Dakota Sandstone, and lower part of the marine Mancos Shale of Cretaceous age (Shawe et al., 1968).

Unconsolidated sediments in the region consist of terrace gravels, mudflows, landslides, alluvial fans, loess, soil, colluvium, talus, and floodplain deposits. Igneous rocks occur as dikes on Glade Mountain and near the southeastern part of Disappointment Valley; as a thick sill in the salt unit of the Paradox Member of the Hermosa Group; and as laccolith bodies in the La Sal and Abajo Mountains (Shawe et al., 1968; W-C, 1982a).

\subsection{STRUCTURAL SETTING}

The Burro Canyon disposal site is in the northeastern portion of the Colorado Plateau, a stable intracontinental subplate characterized by a thick cover of relatively flat-lying Phanerozoic sedimentary rock overlying a complex Precambrian igneous and metamorphic core. The central, stable portion of the Colorado Plateau exhibits characteristics of cratonic areas, while the margins of the subplate exhibit crustal structure similar to more highly active bordering provinces. The Colorado Plateau is bordered on the east, south, and west by the extensional, block-faulted regime of the Rio Grande Rift and the Basin and Range Province (Figure 2.4).

The principal present-day structural elements comprise of the Colorado Plateau (Hunt, 1956):

- Broad west and northwest-trending basins such as the Piceance, Uinta, San Juan, and Navajo Basins.

- Clusters of uplifts that lie between these broad basins, including the Uncompahgre, Monument, San Rafael Swell, Circle Cliffs, Kaibab, Defiance, and Zuni Uplifts. 


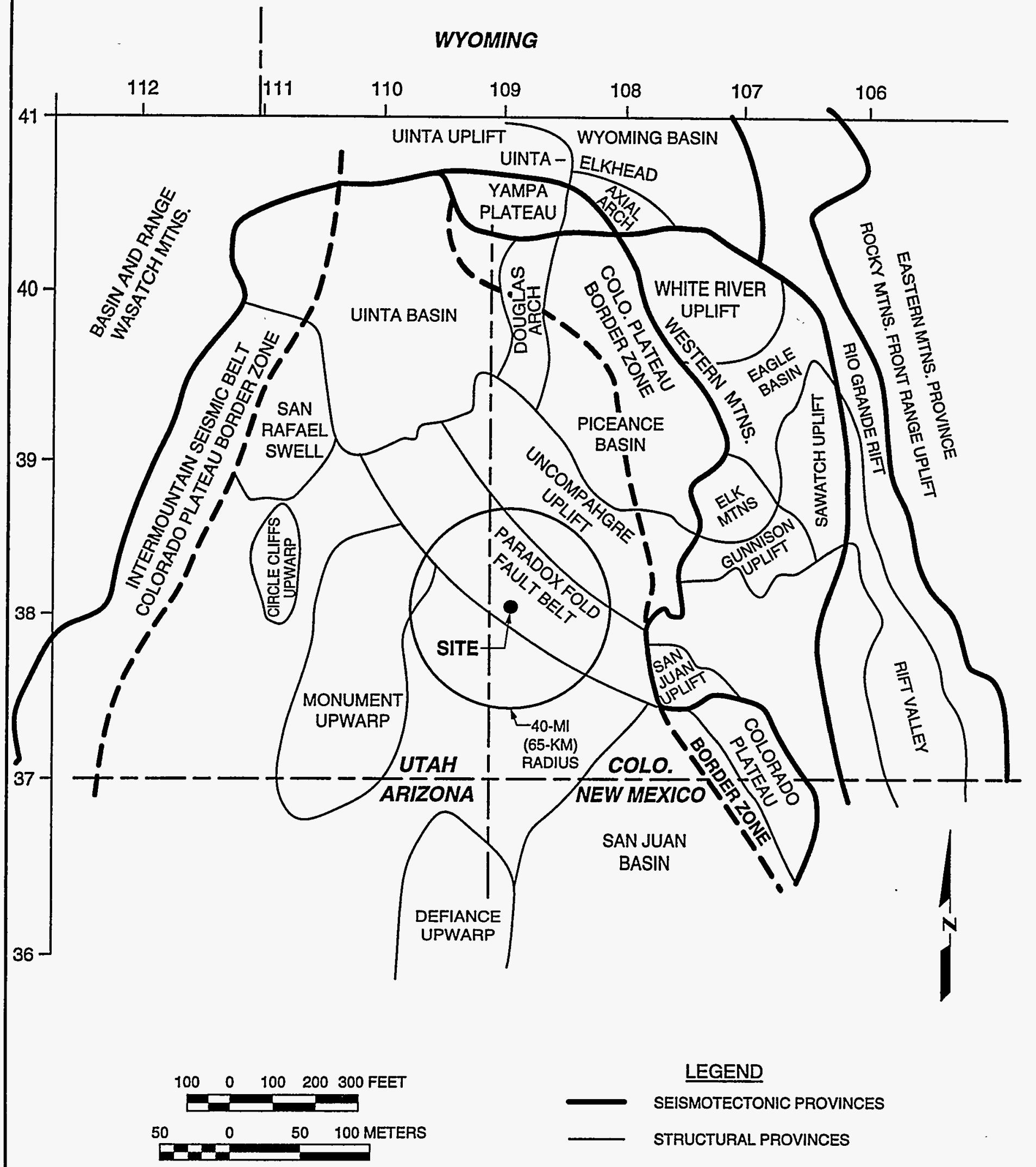

FIGURE 2.4

MODIFIED FROM KIRKHAM AND ROGERS, 1981.

STRUCTURAL AND SEISMOTECTONIC SETTING

BURRO CANYON DISPOSAL SITE NEAR SLICK ROCK, COLORADO 
- Northwest-trending anticlines and faults of east-central Utah and southwestern Colorado, including the Paradox Basin, underlain by thick salt deposits.

- North-trending fault blocks of the high plateaus in Utah and Arizona. These features represent a zone of transition between the Colorado Plateau and Basin and Range Provinces.

- Domes and folds related to laccolithic intrusions, most of which are in the central part of the Plateau.

The present structural elements of the plateau are principally the result of Cenozoic deformation, but follow, at least in part, the trends of older features. Structures in the Precambrian basement undoubtedly have influenced the later tectonic history of the plateau. However, relatively little is known of the Precambrian structure. Precambrian rocks are exposed only in the Uncompahgre Uplift, Grand Canyon, Zuni Mountains, and Defiance Uplift. These rocks consist of a complex series of metasedimentary and metavolcanic rocks cut by a series of large intrusions. During much of Paleozoic and Mesozoic times, the plateau region was a stable continental shelf area. From the Late Mississippian to Permian time, the "Ancestral Rockies" disturbance affected parts of the eastern plateau and the Rocky Mountain region to the east. The Uncompahgre Uplift rose during this time, while the Paradox Basin received large volumes of Pennsyivanian and Permian redbeds and evaporite deposits (Cater, 1970; 1966). The Zuni Mountains and Defiance. Upwarps probably were uplifted at this time (Hunt, 1956). The Late Cretaceous-Eocene Laramide Orogeny produced a series of monoclines and fault-bounded uplifts and basins within the plateau (Tweto, 1980). From the end of the Eocene until Miocene or Pliocene times, the plateau was eroded by the ancestral Colorado River. Since Late Tertiary time, the plateau has experienced gradual uplift at an average rate of $2 \mathrm{~mm} /$ year (Gable and Hatton, 1983). This uplift is regional in character and appears to produce relatively little internal deformation.

The major regional structural and tectonic features of the site region are the Uncompahgre Uplift, the salt anticline region of the Paradox Basin, and the laccolithic centers of the La Sal, Abajo, and Ute Mountains (Figure 2.5).

The Uncompahgre Uplift (or Uncompahgre Plateau) is a large, northwesttrending, asymmetrical block composed of a complex Precambrian igneous and metamorphic core overlain by Mesozoic sedimentary units. The uplift is bounded on the northeastern and southwestern flanks by abrupt, locally faulted monoclines. The northwest-trending salt anticlines of the Paradox Basin lie to the southwest, paralleling the trend of the uplift. On the northeast, the uplift is flanked by the valleys of the Colorado, Gunnison, and Uncompahgre Rivers, Grand Mesa, and the Pieceance Basin. The southeast end of the uplift is terminated by Ridgway Fault (Tweto, 1979; Sullivan et al., 1980) and the San Juan volcanic field. To the northwest, the uplift plunges beneath the Tertiary sedimentary sequence of the Uinta Basin. 
NOTE: STRUCTURE CONTOURS ARE ON THE BASE OF THE DAKOTA SANDSTONE HEAVY LINES INDICATE INFERRED DEEP-SEATED FAULTS.

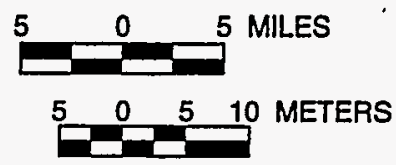

MODIFIED FROM SHAWE, 1970.

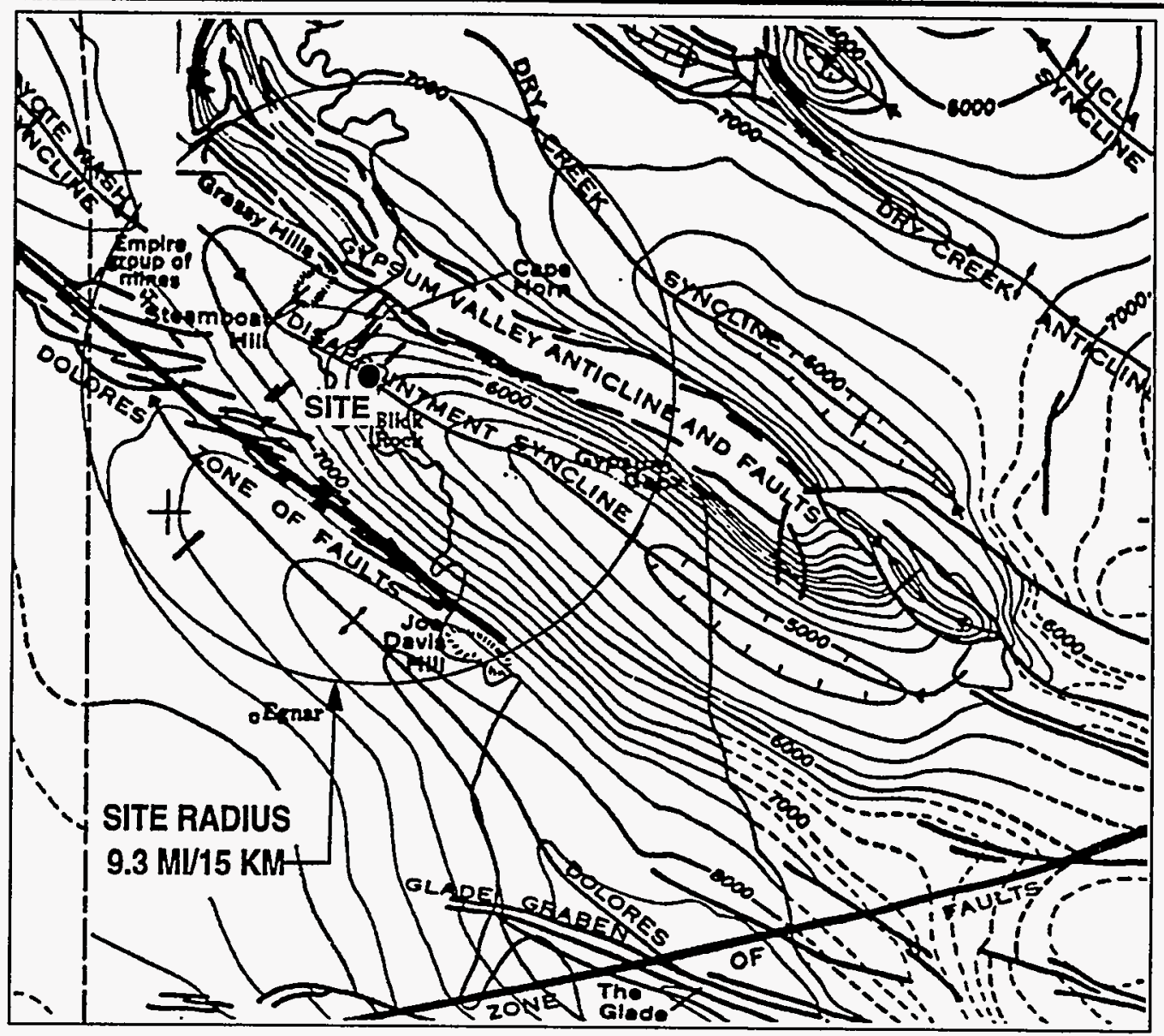

\section{LEGEND}

APPROXIMATE LOCATION OF ZERO THICKNESS OF SALINE FACIES (BOUNDARY OF PARADOX BASIN)

ANTICLINE IN WHICH INTRUSIVE SALT (PARADOX FORMATION) IS EXPOSED

IGNEOUS INTRUSIVE CENTER, GENERALLY A DOMAL UPLIFT

OVERTHRUST MARGIN OF UNCOMPAHGRE UPLIFT; BARBS ON OVERTHRUST BLOCK

f ANTICLINE WITHIN AREA OF POTASH DEPOSITION

$-x-$ LIMIT OF MAJOR POTASH DEPOSITION

20 $0 \quad 20 \quad 40$ MILES

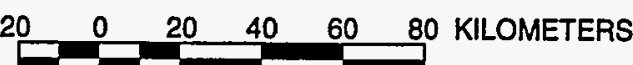

FIGURE 2.5

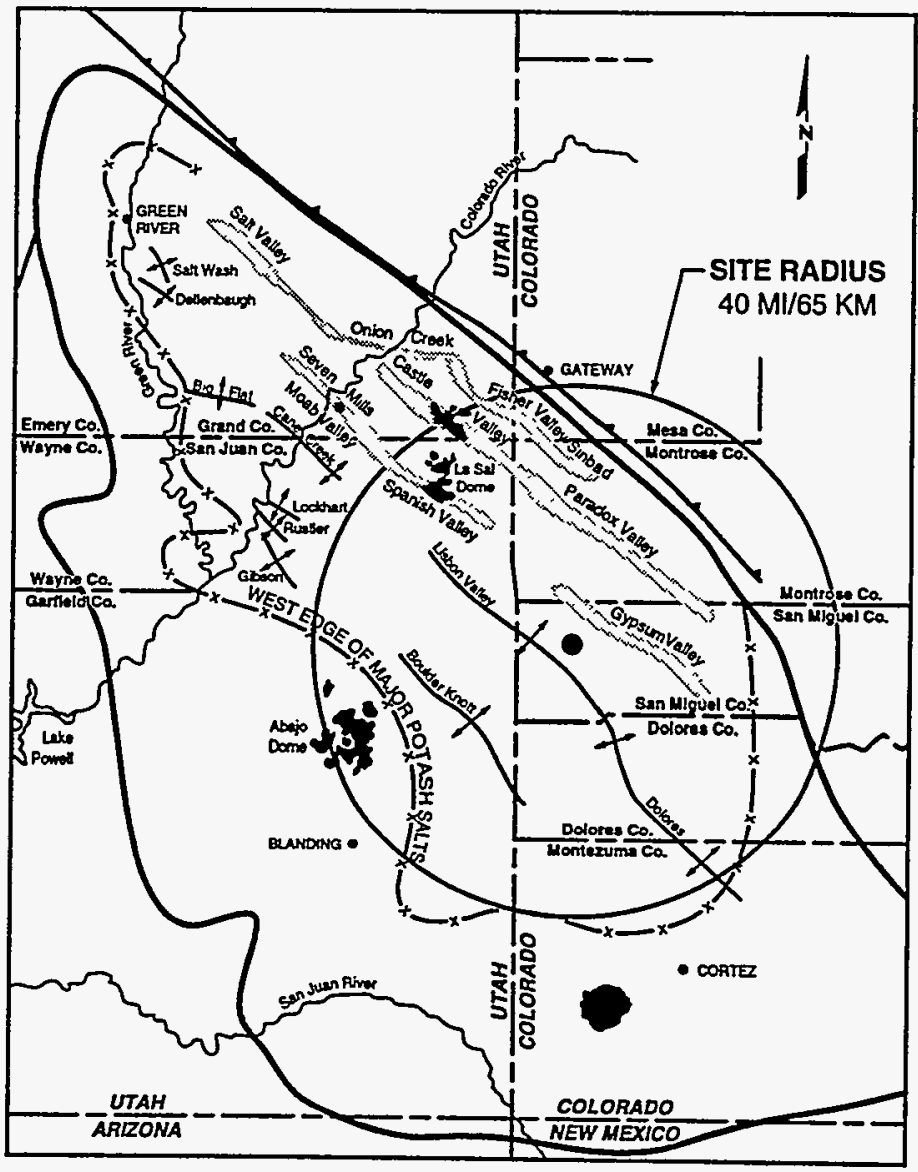
MODIFIED FROM W-C, 1983

REGIONAL GEOLOGIC STRUCTURE, BURRO CANYON, COLORADO, AREA 
The Uncompahgre Uplift has experienced recurrent activity since at least the end of the Paleozoic and may be controlled by deep-seated faults that were established during Precambrian time. The uplift was a prominent structural feature during the "Ancestral Rockies" disturbance in Late Paleozoic (Mississippian-Permian) time. Movement also occurred on bounding faults and monoclines during the Laramide Orogeny in Late Cretaceous to Eocene times. The modern Uncompahgre Uplift is a northeast-tilted block that has apparently experienced considerable Neogene Uplift. The timing of Neogene deformation is uncertain. Movements apparently began during the Miocene or Pliocene and may have persisted well into the Pleistocene (Cater, 1966; Lohman, 1981; Sinnock, 1981b; Kirkham and Rogers, 1981).

Kirkham and Rogers (1981) indicate deformation of the Uncompahgre Uplift may be continuing at the present time. Their study identified 25 faults of Late Cenozoic age flanking the uplift on the northeast and southwest. These faults range in length from 5 to $25 \mathrm{mi}(8$ to $40 \mathrm{~km})$. Faults identified as "potentially active" by Kirkham and Rogers (1981) on the northeastern flank lie at distances ranging from 56 to $75 \mathrm{mi}(90$ to $120 \mathrm{~km}$ ) from the site. Faults lying along the southwestern flank are about $30 \mathrm{mi}(50 \mathrm{~km})$ from the site.

The salt anticline region of the Paradox Basin south of the Uncompahgre Plateau includes the Sinbad, Paradox, Spanish, Lisbon, Gypsum, and Disappointment Valleys (Figure 2.5). Each of these features is the result of folding of sedimentary rocks, flowage of evaporite bodies, erosion, and faulting. The salt anticline region generally lies within a northwest-trending trough, which may have originated as a wide graben in Precambrian igneous and metamorphic sediment rocks between the Uncompahgre Plateau and a Precambrian platform to the west and south (Shawe et al., 1968). This trough may have been an important ancestral control on the deposition of thick Paleozoic and Mesozoic sediments in the Paradox Basin.

The Paradox Basin is a northwest-southeast-trending structural and sedimentary basin bounded on the northeast and east by the Uncompahgre Plateau and the San Juan Mountains, on the south by the Defiance Plateau, and on the west by Circle Cliffs and San Rafael Swell (Ohlen and Mclntyre, 1965). The basin is 200 mi $(320 \mathrm{~km})$ long and $80 \mathrm{mi}(130 \mathrm{~km})$ wide. Five major northwest-trending salt anticlines ranging from 30 to $70 \mathrm{mi}(50$ to $110 \mathrm{~km}$ ) long occur within the basin and are characterized by structurally complex centers 2 to $6 \mathrm{mi}(3$ to $10 \mathrm{~km}$ ) wide and salt cores 4100 to $13,700 \mathrm{ft}(1300$ to $4180 \mathrm{~m})$ thick (Elston and Landis, 1960). The Dolores anticline west of the site and the Gypsum Valley anticline to the east have salt core thicknesses of 4000 and $10,000 \mathrm{ft} 11200$ and $3000 \mathrm{~m}$ ), respectively, while the Disappointment Valley syncline, in which the site is located, has a relatively thin layer of only $1000 \mathrm{ft}(300 \mathrm{~m})$ (Shawe et al., 1968).

The Paradox Basin formed in Pennsylvanian time along a dominant set of northwest-trending faults of pre-Pennsylvanian age. Basin subsidence, accompanied by uplift of the ancestral Uncompahgre highland, resulted in the 
deepest part of the basin occurring adjacent to the present-day Uncompahgre Plateau (Chenoweth, 1984). . Terrestrial and marine sediments, including the salt-bearing unit of the Paradox Member of the Hermosa Group, were deposited in this subsiding basin, creating a wedge of sediment thickening to the northeast to more than $20,000 \mathrm{ft}(6000 \mathrm{~m})$.

The sedimentary rocks in the Paradox Basin are folded in a series of broad, northwest-trending anticlines and synclines generally parallel to the southwestern edge of the Uncompahgre Plateau (Figure 2.4). The folding is related to both the uplift of the plateau and the flowage and intrusion of evaporite rocks into the axial parts of the anticlines (Shawe et al., 1968). Crustal movement associated with the uplift of the Uncompahgre highland ceased by the end of deposition of the Cutler Formation in the Late Permian, although minor upwelling of the evaporites occurred during the Triassic and Jurassic (Chenoweth, 1984; Elston and Landis, 1960). Upwelling of evaporite deposits resulted in steeper dips on successively older formations on the flanks of the anticlines and deposition of younger formations across the upturned and truncated edges of the older formations. The process of upturning, erosion, and deposition of overlapping younger formations continued until the Late Jurassic, when salt from the adjacent synclines had been squeezed out and exhausted (Chenoweth, 1984).

Relaxation of stress during the Cretaceous Period caused initial collapse of the crest of anticlines in the Paradox Basin. Middle and Late Tertiary uplift of the Colorado Plateau reactivated axial graben formation in the salt anticlines. As a consequence of differential overburden pressure, evaporite deposits were extended upward from and moved laterally by flowage along the axial regions of the anticlines, and locally were removed by solution processes by incised river valley (Cater, 1970). The axial regions of the anticlines collapsed as grabens bounded by longitudinal faults or fault zones along the limbs of the structures (Shawe et al., 1968). Many of the graben collapse features are expressed as huge, backward-rotated slump blocks flanking the axial valleys of the eroded anticlines. Basin-like downwarps and sags within the Paradox Basin areas also appear to be the result of salt removal by flowage (Chenoweth, 1984). Continuing removal of salt by flowage toward the deeply incised stream valley in the Paradox Basin indicates that graben development in the anticlines is directly related to downcutting of the Dolores River (Cater, 1970). Faults associated with collapse of salt-cored anticlines in the site region are not tectonically controlled, but result from downdropping of sedimentary rocks overlying areas of salt removal by flowage and solution.

Some laccolithic centers and associated structural features appear to be controlled by the northwest-trending basement structure that results in the alignment of the Uncompahgre Uplift (Cater, 1970). Major laccolithic mountains in the region are the La Sal, the Abajo, and the Ute Mountains (Figure 2.5). Minor intrusive bodies occur in the Klondike, Disappointment Valley, and Glade Mountain areas. Laccolithic igneous intrusions in the La Sal Mountains are of Tertiary age and occur in the midst of the series of salt anticlines and synclines. 
The folding and associated faulting are the result of Late Cretaceous or Early Tertiary deformation and original structures have been complexly modified by repeated plastic deformation of evaporite beds (Hunt, 1958). Middle Tertiary laccolith intrusions postdate the folding. Local Late Tertiary and Quaternary deformations and faulting of Pleistocene and Holocene deposits are related to continued flowage of salt bodies.

Laccolithic igneous intrusions in the Abajo Mountains do not seem to be related to the fold and fault structures of the nearby Paradox Basin, Blanding Basin, or Monument Upwarp. Formation of the Abajo Mountains, by doming of flat-lying sedimentary rocks by forcible igneous intrusions, occurred during the Middle Tertiary (Witkind, 1964). A high-angle, normal fault zone trends eastward across southeastern Utah and southwestern Colorado form grabens on the north and south flanks of the Abajo Mountains. The. Shay and Verdure grabens crossing the Abajo Mountains appear to antedate the laccolithic intrusion and uplift of the mountain area (Witkind, 1964), and were probably formed between Late Cretaceous and Middle Tertiary time. Evidence of possible displacement of a Quaternary gravel-covered pediment on the north side of the Shay Mountain suggests a possible rejuvenation of the graben system since laccolith emplacement in the Oligocene (W-C, 1982a). Quaternary movement on the graben-bounding faults has not been conclusively demonstrated, although geomorphic evidence suggests.it. The age of last movement on the Verdure graben on the south flank of Abajo Mountain may be Oligocene, but overlying Quaternary pediment gravel deposits may be offset by later fault movement (W-C, 1982a).

In the site region, igneous intrusions also occur at Glade Mountain, Disappointment Valley, and Klondike Ridge at the southeast end of Gypsum Valley (Shawe et al., 1968). A fault bounding the Glade graben near the top of Glade Mountain localized intrusion along an igneous dike. A sill intruded into the Paradox Member of the Hermosa Formation is connected with the dike. Igneous intrusions at Klondike Ridge are also connected, with sills occurring in the Mancos Shale and Dakota Sandstone in Disappointment Valley. Dikes and sills in these areas probably were localized by preexisting north-south faults and were emplaced sometime between Early Cenozoic and Miocene times (Shawe et al., 1968). In Disappointment Valley, syncline development most likely continued for a short time after intrusion of the igneous sills.

\subsection{SEISMOTECTONICS}

Seismic hazard studies in much of the southwestern United States are hampered by the lack of a reliable long-term historical record. Movements on major fault systems in the region may have recurrence intervals on the order of tens to hundreds of thousands of years, while the historical record dates back only to the late or mid-19th century. The historical record for Arizona dates to 1776 (DuBois et al., 1982); for Utah to 1850 (Arabasz et al., 1979); and for Colorado to 1870 (Kirkham and Rogers, 1981). Reliable and reasonably complete instrumental records generally date back only to the early 1960s. As a general 
rule, the historical record is probably reliable for moderate to large earthquakes since 1900 to 1910 , while the instrumental record most likely is reliable for earthquakes of magnitude 4.5 or greater since the early $1960 \mathrm{~s}$ (Von Hake, 1984).

In the absence of a reliable long-term historical record, probabilistic analyses of seismic risk are of limited use. Therefore, seismic risk analyses are largely based on studies of the geologic and seismotectonic setting, Cenozoic geologic history, and geomorphic evidence of Late Tertiary and Quaternary fault movements. Fortunately, erosion rates are slow and vegetation generally is sparse in the arid to semiarid climates that prevail in most of the region. Long faults, which are necessary for large earthquakes, will not remain undetected if careful geologic investigations are made (Krinitzsky and Chang, 1975).

The site is near the northeast edge of the Colorado Plateau physiographic and seismotectonic province. Figure 2.4 shows the boundaries of seismotectonic provinces in the site region, as defined for this study. The boundaries are determined on the basis of published studies of Neogene faulting, regional seismicity trends, areas of Cenozoic igneous activity, geophysical data, and the distribution of major physiographic provinces. In Colorado, adjacent to the Colorado Plateau province on the east, the Western Mountains seismotectonic province corresponds to the western part of the southern Rocky Mountains physiographic province. Figure 2.6 shows a plot of historical and instrumentally located earthquake epicenters (for events of magnitude $\geq 3$ ) for the Colorado Plateau region. These data were provided by the NGDC/NOAA (1989).

Beyond the border zones, the Colorado Plateau is surrounded on three sides by the extensional, block-faulted regime of the Basin and Range and Rio Grande Rift Provinces. The Colorado Plateau, Basin and Range, Rio Grande Rift, and Sierra Nevada appear to be part of an interrelated system that has experienced major uplift and extension during the last 20 million years (Thompson and Zoback, 1979). The Basin and Range and Rio Grande Rift bounding the plateau show geologic and geomorphic evidence of repeated surface faulting events associated with large earthquakes during Quaternary time. These areas experienced some of the largest historical earthquakes in the United States. These regions are characterized by large volumes of Cenozoic intrusive rock, thinner crust, higher heat flow, and stress fields oriented differently than the modern stress field in the interior of the Colorado Plateau (Thompson and Zoback, 1979). The boundary of the Colorado Plateau and the Basin and Range Province on the west is marked by the Wasatch Frontal Fault system in Utah, which forms a major segment of the Intermountain Seismic Belt (Smith and Sbar, 1974). The transition zone in northern and central Arizona is referred to as the Arizona border zone. Some of the largest historical earthquakes of the Colorado Plateau occurred in this region (DuBois et al., 1982). The Rio Grande Rift and the eastern Colorado Plateau border zone in New Mexico and southwestern Colorado also have been the focus of elevated seismicity in historical times. A swarm of moderate to large earthquakes occurred in the 


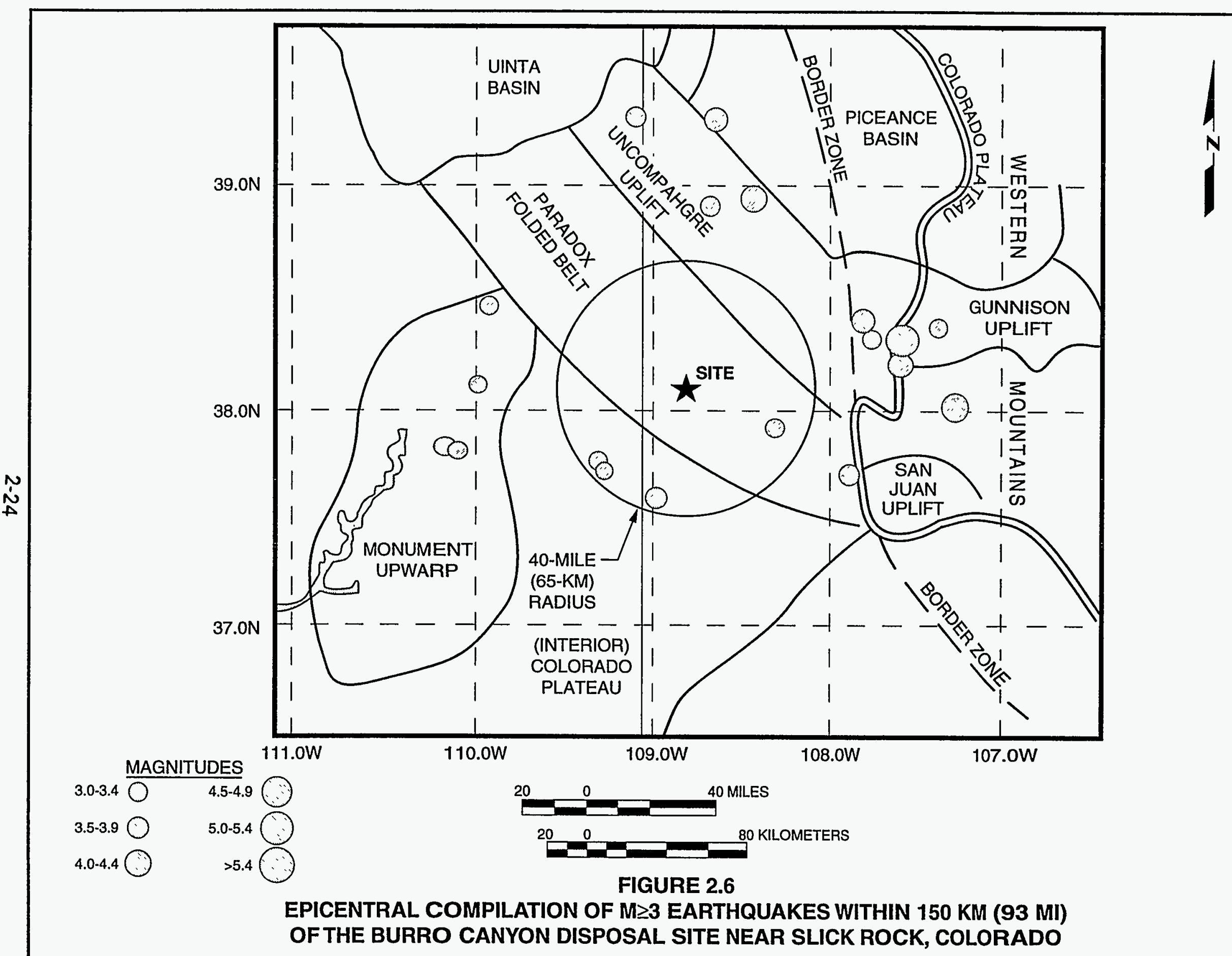


Dulce, New Mexico, region during 1966, and may be related to the movement of magma at depth.

The border zone of the Colorado Plateau and Western Mountain Provinces in southwestern Colorado, which includes the disposal site region, also has experienced a moderate, broadly-distributed level of seismicity during historical times. An area of persistent seismic activity near Montrose, Colorado, may be related to the Ridgway fault, which terminates the southeast end of the Uncompahgre Uplift (Sullivan et al., 1980; Kirkham and Rogers, 1981). To the north, the Colorado Plateau is bordered by the Wyoming Basin, a series of broad basins and uplifts that are structurally and tectonically similar to the Plateau. The transition zone is not marked by elevated seismicity, except for probable mining-related events in the eastern Utah coal-mining belt (Smith and Sbar, 1974). Table 2.2 lists seismotectonic characteristics of the Colorado Plateau and adjacent provinces.

\section{Colorado Plateau seismotectonic province}

The modern Colorado Plateau is composed of a stable interior portion bounded on the west, south, and east by more highly active border zones. The interior and border zones are defined as separate subprovinces and the boundary is drawn at the $25-\mathrm{mi}(40-\mathrm{km})$ crustal thickness contour. The border zones lie within the physiographic boundary of the Colorado Plateau but are characterized by elevated seismicity, thinner crust, higher heat flow, common normal faulting, and elevated levels of Tertiary and Quaternary volcanism relative to the interior. Nearly all the larger historical earthquakes of the Plateau occurred within the border zones.

The Colorado Plateau is a major continental plate that has been uplifted since Late Tertiary time at a rate of between 0.08 to 0.12 inches $(2.0$ to $3.0 \mathrm{~mm})$ per year (Gable and Hatton, 1983). The plateau has experienced little internal distortion in contrast with the more tectonically active border regions of the plateau that includes the Rio Grande Rift, the Arizona Basin and Range province, and the Intermountain Seismic Zone. Tables 2.2 and 2.3 list the major seismotectonic characteristics of the Colorado Plateau interior province. The average thickness of the earth's crust beneath this region is $25 \mathrm{mi}(40 \mathrm{~km})$ (Wong et al., 1987). Lithosphere thickness averages $50 \mathrm{mi}(80 \mathrm{~km})$. Earthquake focal depths of 3 to $16 \mathrm{mi}(5$ to $26 \mathrm{~km}$ ) are recorded for seismic events within the province interior (Giardina, 1977). The faulting mode is primarily strike-slip and thrust with a north-northeast direction of least principal horizontal stress (Zoback and Zoback, 1980).

Neogene faulting is generally rare within the interior portion of the Colorado Plateau, except for faulting associated with the Uncompahgre Uplift and the collapsed salt anticlines of the Paradox Valley. Earthquakes are rare. Wong (1984) classified the historical seismicity of the interior portion as very low level, with events of small-to-moderate magnitude and diffusely distributed 


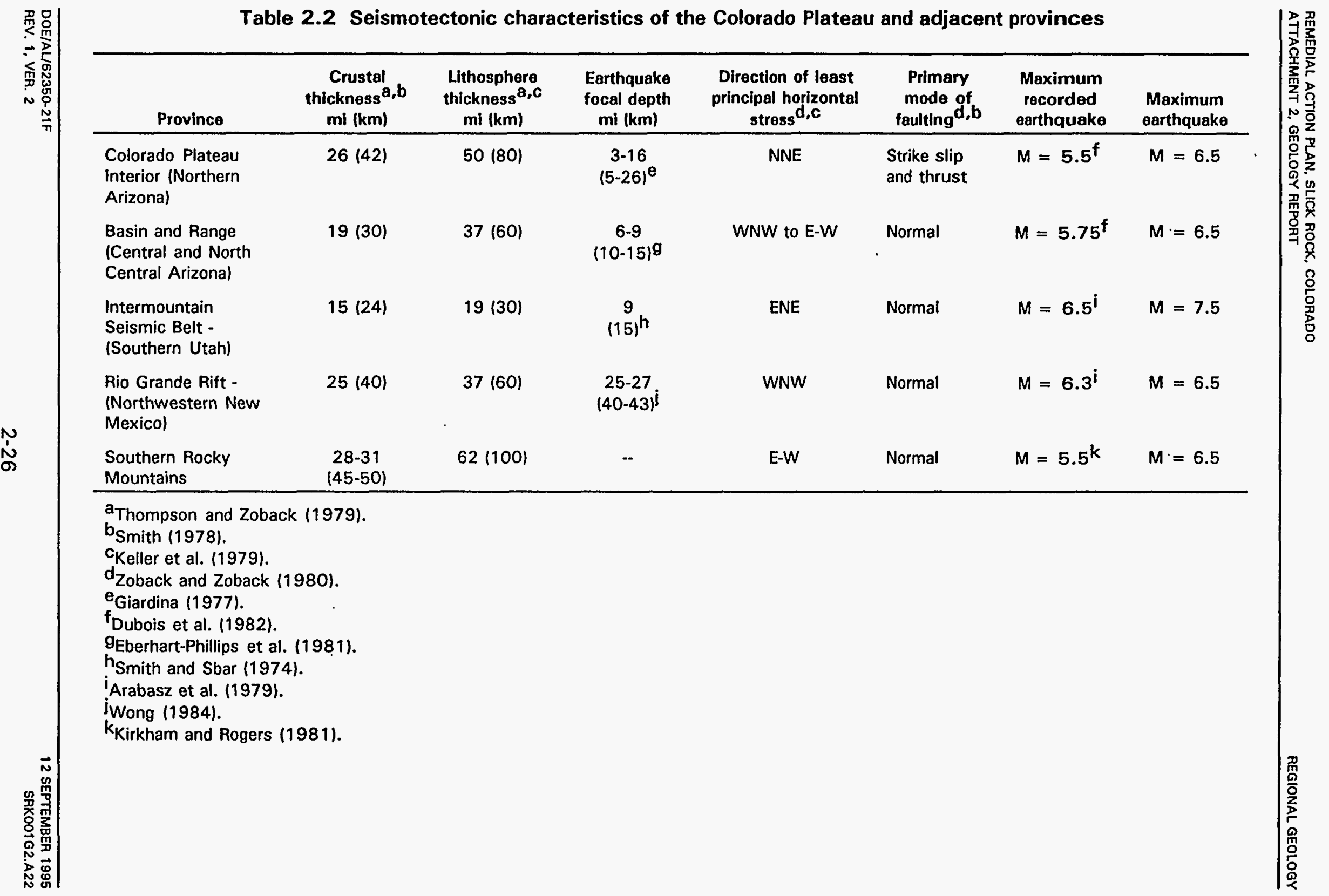


Table 2.3 Probabilistic estimates of maximum acceleration, velocity, and intensity in the Burro Canyon, Colorado, site area

\begin{tabular}{|c|c|c|c|c|}
\hline Source & $\begin{array}{l}\text { Return period or } \\
\text { probability }\end{array}$ & $\begin{array}{c}\text { Maximum } \\
\text { acceleration } \\
\text { (g) }\end{array}$ & $\begin{array}{l}\text { Maximum } \\
\text { velocity } \\
(\mathrm{cm} / \mathrm{s})\end{array}$ & Maximum MMI \\
\hline $\begin{array}{l}\text { Liu and DeCapua } \\
(1975)\end{array}$ & 100 years & 0.02 to 0.03 & - & IV-V \\
\hline $\begin{array}{l}\text { Algermissen and } \\
\text { Perkins (1976) }\end{array}$ & $\begin{array}{l}90 \% \text { probability of } \\
\text { not being exceeded } \\
\text { in } 50 \text { years }\end{array}$ & 0.03 to 0.04 & - & -- \\
\hline ATC, (1978) & -- & 0.04 to 0.05 & -- & -- \\
\hline $\begin{array}{l}\text { Algermissen et al. } \\
\text { (1982) }\end{array}$ & $\begin{array}{l}90 \% \text { probability of } \\
\text { not being exceeded } \\
\text { in } 10 \text { years }\end{array}$ & $<0.04$ & $<2$ & -- \\
\hline $\begin{array}{l}\text { Algermissen et al. } \\
\text { (1982) }\end{array}$ & $\begin{array}{l}90 \% \text { probability of } \\
\text { not being exceeded } \\
\text { in } 50 \text { years }\end{array}$ & 0.04 to 0.05 & 2 & -- \\
\hline $\begin{array}{l}\text { Algermissen et al. } \\
\text { (1982) }\end{array}$ & $\begin{array}{l}90 \% \text { probability of } \\
\text { not being exceeded } \\
\text { in } 250 \text { years }\end{array}$ & 0.10 to 0.12 & $4-6$ & - \\
\hline
\end{tabular}

Dash indicates data not available.

$\mathrm{cm} / \mathrm{s}$ - centimeters per second.

$\mathrm{g}$ - lateral acceleration due to gravity. 
epicenters. The largest instrumentally recorded earthquakes within the interior portion fell in the magnitude range 4.5 to 5.0 .

The largest historical earthquakes recorded within the Colorado Plateau occurred in the border zones, including the following:

- Events of estimated magnitudes 5.5 to $5.75\left(\mathrm{M}_{\mathrm{L}}\right)$ at Lockett Tanks, Arizona, in 1912 and Fredonia, Arizona, in 1959 (DuBois et al., 1982). These events occurred within the Arizona border zone separating the Colorado Plateau from the Basin and Range Province to the south.

- The Dulce, New Mexico, earthquake of 23 January 1966, of magnitude $\left(M_{b}\right) 5.5$ (NGDC/NOAA, 1994). This event occurred in the zone of transition between the Colorado Plateau and Rio Grande Rift (Herrmann et al., 1980).

- The earthquake of 11 October 1960 , of magnitude 5.5, northeast of Ridgway, Colorado, which was felt strongly in the Ridgway-Montrose area. This event may be associated with the Ridgway fault, which terminates the southeastern end of the Uncompahgre Uplift, marks the northwestern boundary of the San Juan volcanic field, and may be the boundary between the Colorado Plateau and Western Mountain Provinces (Sullivan and Martin, 1981; Kirkham and Rogers, 1981).

Recurrence intervals have not been established for large earthquakes within the Colorado Plateau. They may be on the order of tens to hundreds of thousands of years.

Kirkham and Rogers (1981) identified several faults with apparent Quaternary movement associated with the Uncompahgre Uplift and the salt anticline regions of the Colorado Plateau. Along the northeast flank of the Uncompahgre Uplift, an east-west-trending fault offsets Quaternary pediment gravels about $4 \mathrm{ft}$ $(1.2 \mathrm{~m})$ and the underlying Mancos Shale is offset about $10 \mathrm{ft}(3 \mathrm{~m})$. Ely et al. (1986) reported a magnitude 2.9 earthquake on this fault in 1985 and concluded the fault was active. Other faults along the northeastern flank of the uplift appear to be no younger than Laramide age. Faults expressing Quaternary movement also occur along the southwestern flank of the Uncompahgre Uplift. The Ute Creek graben-bounding faults appear to have been active during the Late Pliocene and Early Pleistocene and may be active today. Other faults indicate Quaternary movement; the most important of these is the Ridgway fault bounding the southern end of the uplift. The Ridgway fault offsets Quaternary gravels and is associated with historical earthquakes.

Nontectonic faults associated with the collapse of salt anticlines are common in the Paradox Basin. These faults are the result of salt flowage and are not likely to generate earthquakes larger than magnitude 4.0 or 5.0 (Kirkham and Rogers, 1981). Wong et al. (1987) observed that the nature of seismicity in 
salt anticlines in the potash mining area near Moab, Utah, was less than magnitude 3.0.

Two faults along the flanks of Abajo Mountain west of Slick Rock have probable Quaternary movement. The Shay graben faults north of the mountain and the Verdure graben faults on its south flank initially were formed during emplacement of the Abajo Mountain laccolith. Geomorphic evidence (W-C, 1982a) suggests parts of the Shay graben faults have experienced Quaternary movement. Renewed movement on the Verdure graben faults also may have occurred, but the geologic evidence is less certain.

The area of western and southwestern Colorado that includes the Slick Rock sites does not display some of the significant characteristics of the typical Colorado Plateau border zones (e.g., thinner crust and higher heat flow). Physiographically, this transition is marked by increasing elevation within the uplifted areas adjacent to the Rocky Mountains, in contrast to the marked elevation decreases characteristic of the transitions to the Basin and Range and Rio Grande Rift Provinces. However, the transition is marked by a notable increase in the level of seismicity relative to the Colorado Plateau interior. This seismicity is broadly centered over the Colorado Plateau/Western Mountain Province transition zone (Kirkham and Rogers, 1981). Geologic and geomorphic evidence has been interpreted as showing that certain structures in this region, notably the Uncompahgre Uplift, experienced considerable Late Tertiary uplift that may continue today.

\section{Intermountain Seismic Zone}

Seismicity throughout the Intermountain Seismic Zone is characterized by earthquake focal depths less than $9.3 \mathrm{mi}(15 \mathrm{~km})$ (Smith and Sbar, 1974). Most major faults trend north-northwest. The general direction of least principal horizontal stress is east-northeast (Table 2.2). Fault movement is mainly normal slip. The current stress regime of northwest-southwest extension appears to control historic surface faulting.

The entire zone has experienced more than 15 earthquakes of magnitude 6.0 or greater since the mid-1800s (Wong, 1984). The largest recorded event was the 1959 Hebgen Lake, Montana, earthquake of magnitude 7.1. Seismicity near Salt Lake City, Utah, is anomalously low. In southern Utah, historic earthquakes have ranged in intensity from III to VI (NGDC/NOAA, 1994). Earthquake epicenters generally have poor correlation with Late Cenozoic faults (Wong, 1984). This may be caused by listric faulting and the occurrence of earthquakes on curved fault surfaces at depth. Quaternary deposit offset along some fault zones is evident. The maximum recorded earthquake in southern Utah was a magnitude 6.5 event near Richfield in 1901 (Table 2.2). Figure 2.6. shows historical earthquake epicenter distributions for the Intermountain Seismic Belt. 
The Intermountain Seismic Belt, which lies outside the site region, includes the Wasatch Frontal Fault System and other major potentially active faults of northern and central Utah. This zone is highly seismic and capable of large earthquakes up to $M_{L} 7.5$ (Arabasz et al., 1979).

\section{Arizona Basin and Range Province}

The Arizona Basin and Range Province lies south and west of the Colorado Plateau rim. Because of the distance from the site $(300 \mathrm{mi}[500 \mathrm{~km}])$, seismicity from the region is not significant.

\section{Rio Grande Rift}

The Rio Grande Rift section of the border zone lies in western New Mexico along the eastern edge of the Colorado Plateau (Figure 2.4). The rift zone is $140 \mathrm{mi}(230 \mathrm{~km})$ from the site and will not have a significant effect on the seismic characterization of the site.

\section{Western Mountains Province}

The mountainous areas west of the Rio Grande Rift province form the Western Mountains Province of the Colorado Plateau (Figure 2.4). This province includes the San Juan Mountains, Elk and West Elk Mountains, west flank of the Sawatch Range, White River Uplift, and Gunnison Uplift. The Sawatch and White River Uplifts lack pre-Laramide expression, but their borders may be controlled in part by older basement faults (Tweto, 1980). Neogene faults are scarce in this province. Most faults expressing Neogene movement are associated with evaporite flowage or caldera collapse (Kirkham and Rogers, 1981). Despite the apparent absence of major Neogene faults, numerous earthquakes have been recorded within the province. The nearest approach to the site of this province is approximately $65 \mathrm{mi}(110 \mathrm{~km})$. The largest historical earthquake felt in the province was a magnitude 5.5 event near Montrose (Kirkham and Rogers, 1981). No major tectonic faults have been proven to have had Quaternary activity. Crustal thickness of the Southern Rocky Mountains region averages 28 to $31 \mathrm{mi}(45$ to $50 \mathrm{~km}$ ) thick (Table 2.2). Earthquake focal depths have not been calculated from seismic events. Most faults have normal slip movement.

\section{Review of seismic data for the site region}

\section{Epicentral compilation}

An epicentral compilation of the earthquake database was obtained from NGDC/NOAA (1994). Table 2.4 was derived from this list; it represents all earthquakes of magnitude 3.0 and greater within a radius of $93 \mathrm{mi}(150 \mathrm{~km})$. Figure 2.6 is a plot of these epicenters with the structural/tectonic provinces superimposed over the map. Except for one event in 1941, the oldest instrumentally located earthquake in the site region was a magnitude 5.0 at 


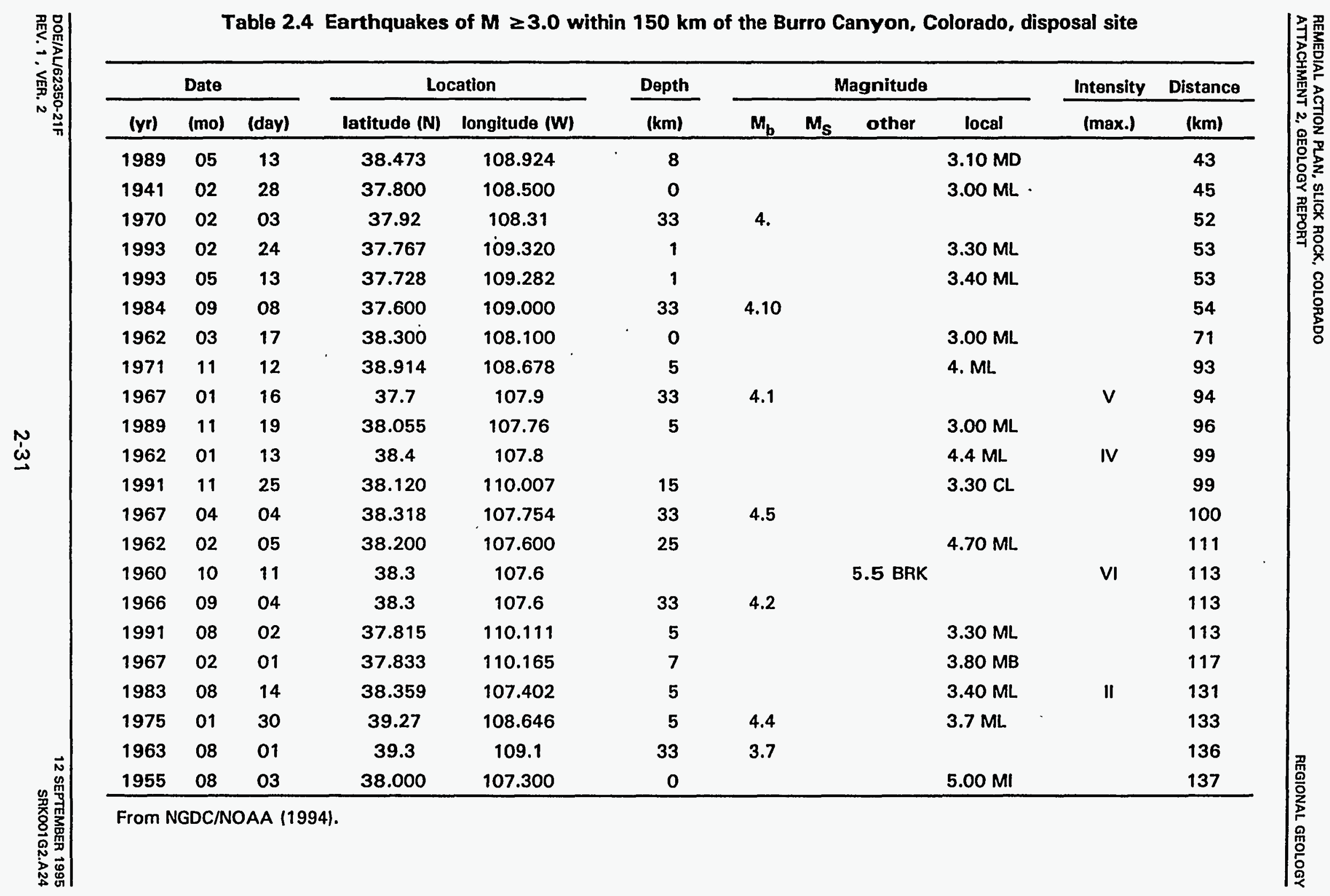


$137 \mathrm{~km}$ distance that occurred in 1955. Few low-magnitude earthquakes could be located prior to 1963 (NGDC/NOAA, 1994). Increases in recorded earthquakes of this magnitude since that time probably are more a function of increases in instrumental network capability rather than increases in seismic activity. A total of 22 events were recorded in the $150-\mathrm{km}$ site radius. The greatest activity occurs on the boundary of the Colorado Plateau with the Uncompahgre Uplift and within the uplift.

Six events of magnitude 3.0 or greater lie within the $40-\mathrm{mi}(65-\mathrm{km})$ site region. The six earthquakes ranged in magnitude from 3.0 to 4.1 and also are plotted on the fault map, Plate 2.1. Within the site region, three events, including one of magnitude 4.1, occurred in the vicinity of the fault swarm identified as fault group 2; one event was located on the flanks of the Dolores anticline, in fault group 10; one magnitude 4.0 event is located on the eastern extension of the Gypsum Valley salt anticline in fault group 9; and one event is located near the Sinbad Valley salt anticline and the Uncompahgre Uplift boundary in fault group 5. The nearest epicenter to the site of magnitude 3.0 or greater is at a distance of $27 \mathrm{mi}(43 \mathrm{~km})$.

The margin of error for locating the 1941 earthquake (magnitude 3.0), is expected to be about 0.5 degrees, or about $30 \mathrm{mi}(48 \mathrm{~km})$, because of the great distances between regional seismograph stations (NGDC/NOAA, 1994). This event and two other earthquakes seem to be related to activity along the boundary of the Uncompahgre Uplift. The other three earthquakes in the vicinity of fault group 2, with magnitudes ranging from 3.3 to 4.1 , are on a trend with the Abajo Mountain and Verdure graben fault system. Because of the possible Quaternary faults identified there with lacolith structure, the group is conservatively considered an active tectonic fault system and not part of the salt flowage activity.

Except for the 2.9 magnitude event in 1985 on the axis of the Uncompahgre Uplift, no other earthquake is specifically associated with a known fault (Ely et al., 1986). The recently achieved accuracy of the instrumentally located earthquakes for events as small as magnitude 3.0 suggest earthquake relationships could be established with the salt core anticline collapse structures.

\section{Determination of ME}

Instrumental earthquake data for the region are representative primarily of the plateau border zone and are insufficient to determine ME value for the plateau interior. Also, the historical record is extremely limited and probably less reliable. The scarcity of recorded earthquakes of magnitude 5.0 and greater also limits the reliability of the ME determination for the border zones. Kirkham and Rogers (1981) adopted 6.5 as the ME value for the Colorado Plateau. This value is recommended as the ME value for the Colorado Plateau interior and border zones together. 
The data do not permit any estimate of the recurrence interval for the ME event within the interior province; however, it may be on the order of tens to hundreds of thousands of years. For the border zones, a reasonable estimate can be made on the basis of the historical record. Assuming the records for moderate to large earthquakes are complete since 1900 , the database covers a period of 85 years. This value represents an absolute minimum recurrence interval for the border zones. If one magnitude 6.5 earthquake is conservatively assumed to occur every 85 years within the approximately 164,000 -square-mile $\left(\mathrm{mi}^{2}\right)$ $\left(425,000\right.$-square-kilometer $\left[\mathrm{km}^{2}\right]$ ) area of the Colorado Plateau (interior and border zones), the frequency of the occurrence of a magnitude 6.5 event within any $9.3-\mathrm{mi}(15-\mathrm{km})$ radius (an area of $272 \mathrm{mi}^{2}\left[707 \mathrm{~km}^{2}\right]$ within the region is $36 \times 10^{6}$ years, $\mathrm{km}^{2}$, or $0.028 \times 10^{-6}$ events $/ \mathrm{km}^{2} /$ year. Thus the recurrence interval of an ME earthquake within any $9.3-\mathrm{mi}(15-\mathrm{km})$ radius area is 50,000 years.

\section{Determination of a floating earthquake magnitude}

The definition of an FE adopted for use in UMTRA Project seismic hazard evaluations is "an earthquake within a specific seismotectonic province which is not associated with a known tectonic structure." It is important to distinguish between the terms ME and FE. The ME magnitude should be larger than the FE magnitude because large earthquakes generally are associated with ground breakage on known tectonic structures. The FE magnitude should never be greater than the ME.

Therefore, the maximum FE magnitude should equal the threshold magnitude at which ground breakage will occur. The threshold magnitude generally is agreed to be 6.2 and the distance of the FE from a site is assumed to be $9.3 \mathrm{mi}$ $(15 \mathrm{~km})$ (Section 1.1). These assumptions (DOE, 1985) were adopted in the Technical Approach Document (TAD) (DOE, 1989). The FE for the Colorado Plateau selected as the 6.2 threshold earthquake will have a resultant 0.21 gravity (g) PHA based on a 9.3-mi $(15-\mathrm{km})$ site radius (Campbell, 1981). Keaton (1994a; 1994b) shows this approach is still valid. Campbell and Bozorgnia (1994) modified the attenuation relationship Campbell initially used in this assessment Campbell (1981), slightly increasing the PHA for this theoretical event from 0.21 to $0.23 \mathrm{~g}$. This changes the long-term seismic coefficient (two-thirds of PHA) from 0.14 to $0.15 \mathrm{~g}$, respectively.

The advantage of using the Campbell and Bozorgnia (1994) approach is that it allows definition of the fault and rock types. Personal communication with Kenneth W. Campbell (Keaton, 1994) shows the equation also allows a combination of fault types. For example, using the descriptor term for a reverse or oblique fault with a soft rock site would result in a peak ground acceleration (PGA) of $0.229 \mathrm{~g}$, whereas a normal or strike-slip fault at the same site would result in $0.182 \mathrm{~g}$. The use of a combination fault descriptor (i.e., 0.5 instead of 1.0 or 0.0 ) for this site would calculate as $0.204 \mathrm{~g}$. If a hard rock site is designated instead, the combination fault type calculation would result in 
$0.172 \mathrm{~g}$. Shaw (1970) indicates the Precambrian basement faults in the Slick Rock region are normal, dip-slip faults.

It is recommended that where the reverse/oblique fault is not the dominant fault type, that the combination fault descriptor be used instead of the less conservative normal/strike-slip fault type, with a soft rock site descriptor to estimate the FE PGA.

\section{Effects of maximum earthquakes on other regional seismotectonic features}

Remote seismotectonic provinces bordering the Colorado Plateau Province include the Western Mountain Province, at a distance of $62 \mathrm{mi}(100 \mathrm{~km})$; the Intermountain Seismic Belt, at a distance of $124 \mathrm{mi}(200 \mathrm{~km})$; the Wyoming Basin, at a distance of $186 \mathrm{mi}(300 \mathrm{~km})$; and the Rio Grande Rift, at a distance of $155 \mathrm{mi}(250 \mathrm{~km})$.

Based on the distance-attenuation relationship such as Campbell (1981), an ME of magnitude 8.2 at a distance of $65 \mathrm{~km}$ would result in a PHA at the site that would be less than the FE for the region. Therefore, remote seismic source regions in excess of $65 \mathrm{~km}$ are not significant to the seismic stability analysis.

\section{Western Mountain Province}

Earthquake epicentral maps of the Colorado Plateau region show a heightened level of seismic activity possibly coinciding with the border zone along the contact with the Western Mountain Province, which is located roughly within $62 \mathrm{mi}(100 \mathrm{~km})$ of the site. The ME magnitude for the Colorado Plateau is 5.5 to 6.5, and for the Western Mountain Province is 6.5 (Kirkham and Rogers, 1981; Campbell and Bozorgnia, 1994). Therefore, the ME associated with the border zone of the two provinces is assumed here to be magnitude 6.5 .

The maximum horizontal acceleration in rock expected at the site area, from a possible ME event having a magnitude of 6.5 , occurring within $65 \mathrm{~km}$ of the sites area, is $0.03 \mathrm{~g}$, as detailed in Table 2.5.

\section{Paradox Basin salt collapse structures}

Major structural features within the Paradox Basin related to site design parameters consist of faulted salt anticline crests. Faults formed during collapse of the anticline crest during flowage of the salt cores are not tectonic features (Cater, 1970). Movement along these failure surfaces proceeds more as a gradual creep than sudden slip.

Wong (1984) listed 22 earthquake events within the Paradox Basin from 1853 to 1979. A program of microearthquake monitoring from 1979 to 1982 recorded 316 microearthquakes of magnitude $\left(M_{L}\right)$ zero to 2.4 (Wong, 1984). Most of these events were associated with mine blasting or Colorado 
Table 2.5 Estimated maximum peak horizontal ground acceleration from MEs on regional seismotectonic features, Burro Canyon Colorado, site area

\begin{tabular}{|c|c|c|c|}
\hline Source area & ME magnitude & $\begin{array}{l}\text { Approximate } \\
\text { distance from } \\
\text { site area }\end{array}$ & $\begin{array}{l}\text { Maximum free-field, } \\
\text { nonamplified peak horizontal } \\
\text { ground acceleration } \\
\text { expected at site area } \\
\text { (fraction of unit gravity) }\end{array}$ \\
\hline $\begin{array}{l}\text { Big Gypsum Salt Collapse } \\
\text { Structure }\end{array}$ & $5.0^{b}$ & $\begin{array}{c}4.0 \mathrm{mi} \\
(6.4 \mathrm{~km})\end{array}$ & 0.21 \\
\hline Intermountain Seismic Belt & $7.0-7.5$ & $\begin{array}{c}137 \mathrm{mi} \\
(220 \mathrm{~km})\end{array}$ & 0.02 \\
\hline Rio Grande Rift & $6.5-7.5$ & $\begin{array}{c}155 \mathrm{mi} \\
(249 \mathrm{~km})\end{array}$ & 0.02 \\
\hline Wyoming Basin & $5.7-6.5$ & $\begin{array}{c}186 \mathrm{mi} \\
(299 \mathrm{~km})\end{array}$ & 0.005 \\
\hline $\begin{array}{l}\text { Colorado Plateau/Western } \\
\text { Mountain Province } \\
\text { transition zone }\end{array}$ & 6.5 & $\begin{array}{c}62 \mathrm{mi} \\
(100 \mathrm{~km})\end{array}$ & 0.03 \\
\hline
\end{tabular}

${ }^{a}$ Calculated from acceleration/attenuation relationship of Campbell (1981) and Campbell and Bozorgnia (1994).

${ }^{b}$ Calculated from fault rupture area/magnitude relationship of Woodward-Clyde (W-C, 1982b).

River-induced seismicity. The largest magnitude event occurred near Moab, Utah, and was a magnitude $\left(\mathrm{M}_{\mathrm{b}}\right)$ of 3.8 (Wong, 1984).

The ME for the nontectonic salt collapse structures is based on the Kirkham and Rogers (1981) assessment that it is unlikely the salt core anticline collapse features are capable of generating more than a magnitude 4.0 or 5.0 earthquake. This assessment is supported by a theory of Campbell (1984) that where rupture of the crystalline basement rock is not involved, the maximum magnitude of such events is very likely $M=\mathbf{5 . 5}$ or less. Campbell concludes the basement rock provides the primary seismogenic source in larger earthquakes, and it is unlikely that stresses within the sedimentary material contribute any substantial energy to ground motion. This approach concludes that the basement faults of the Paradox Basin are not capable in the present seismotectonic regime and that fault length relationships are not applicable to nontectonic structures.

The depth of faulting and the potential for development of energy during an earthquake is further limited because the faults very likely do not extend into the halite salt core (W-C, 1983). The potential location for ME occurrence from this process likely is not from existing graben structures but from previously 
uncollapsed portions of structures such as the southwest half of the Dolores anticline-Lisbon Valley structure, the youngest of the collapsed structures.

\subsection{MINERAL RESOURCES}

Known economic mineral resources in the area are limited to uranium and vanadium ores and oil and gas deposits. The area has been mined extensively for uranium-vanadium deposits, but economically significant ore bodies are still present in the area. Oil and gas are produced from structural traps within the Paradox and Libson Valleys and other carbonate units within the salt anticline region of western Colorado and eastern Utah. Figures 2.7 and 2.8 show the locations of resource development in the region (W-C, 1983). There appears to be little potential for potash or minerals in natural brine. The nearest potential for potash and brine mineral deposits is in nearby Gypsum Valley, a diapiric collapse salt anticline structure (Figure 2.5). Uranium mining, gas well placement, and potash exploration have occurred on the flanks of this structure (W-C, 1983). At the Burro Canyon disposal site, the Disappointment Valley syncline reportedly has only $1000 \mathrm{ft}(305 \mathrm{~m})$ of Paradox Salt deposits and is an unlikely source of economic deposits compared with the 10,000-ft (3050-m) deposits in Gypsum Valley.

Uranium-vanadium ore deposits in the Slick Rock district and the Uravan mineral belt occur mainly in the thick sandstone deposits of the Salt Wash Member of the Morrison Formation (Shawe et al., 1959). The upper sandstone in the Slick Rock area contains the majority of the ore deposits; however, small localized deposits also occur in the lower sandstones and mudstones as well as in the coarse conglomeratic sandstones of the lower part of the overlying Brushy Basin Member (Chenoweth, 1981). Both of these units crop out extensively in the area and have been mined since the early 1900s. Uranium-vanadium mines in the area of the sites no longer operate. The mine nearest the sites is the Burro Canyon mine, formerly operated by Umetco. Figure 2.8 shows the area of underground workings and mining claims relative to the site. The approach nearest the site is the mine vent $2300 \mathrm{ft}(700 \mathrm{~m})$ to the southwest. The mine was abandoned in 1983. Based on the elevations of the ore zone in the nearest exploratory hole logged by Umetco, this zone would be approximately $910 \mathrm{ft}$ $(280 \mathrm{~m})$ below the site. The ore zone typically is in discontinuous lenses and pockets from 0.5 to $2.0 \mathrm{ft}(0.2$ to $0.6 \mathrm{~m})$ thick. Occasionally there may be two zones up to $75 \mathrm{ft}(23 \mathrm{~m})$ apart. The potential for future mining activity in the Slick Rock-Uravan mining district is dependent on uranium prices. A renewed market for uranium ores could stimulate new exploration and development of deposits in the area.

Extensive oil and gas resources have been developed in the salt anticline region surrounding the Slick Rock area. Most production has been in the Paradox Basin, north of the Libson Basin in Utah and northwest of the site (Wiegand, 1981). Oil and gas occur in structural traps associated with Late Paleozoic salt-cored anticlines. Extensive undeveloped oil and gas deposits are believed to exist in the Paradox Basin area (Krivanek, 1981) and in the 


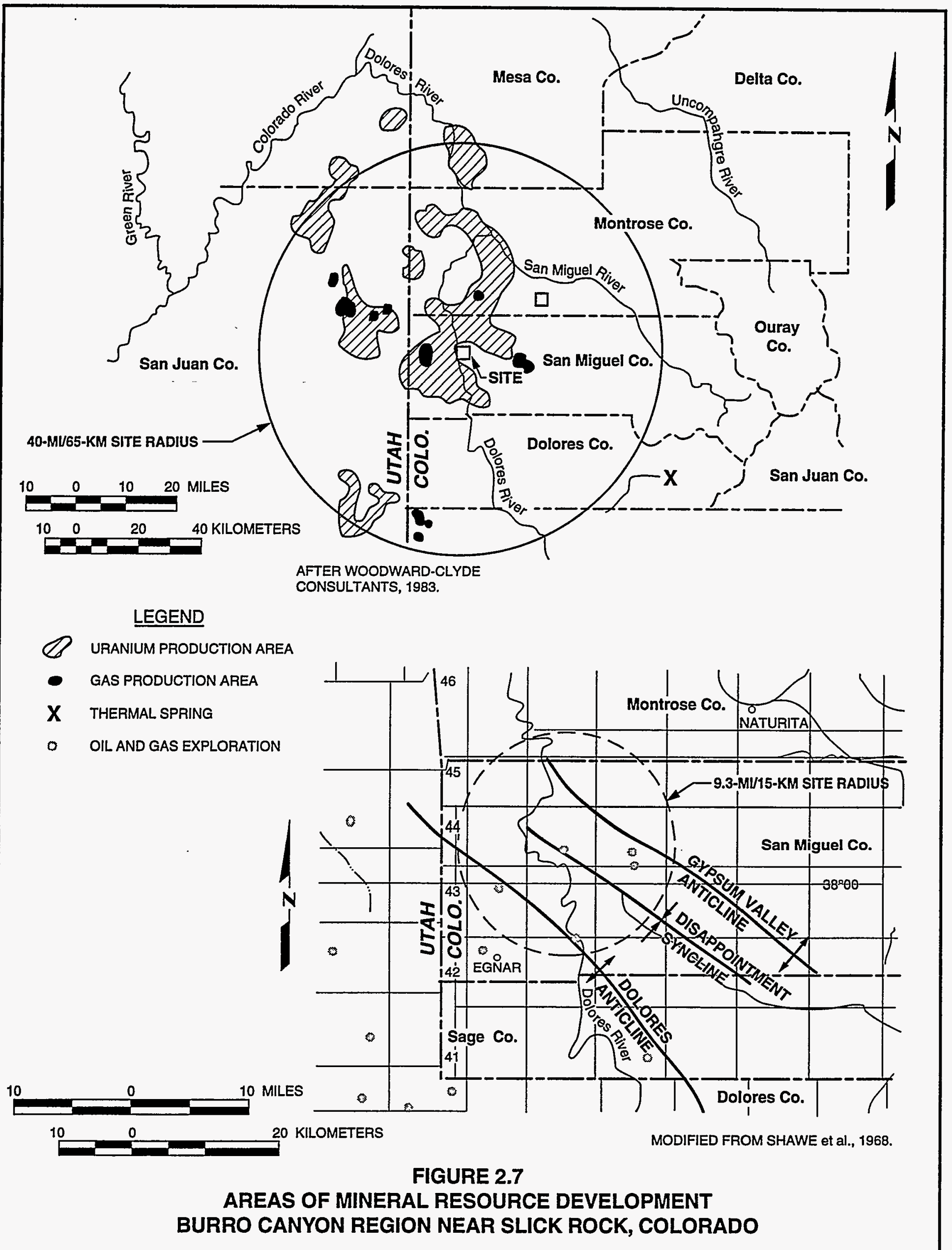




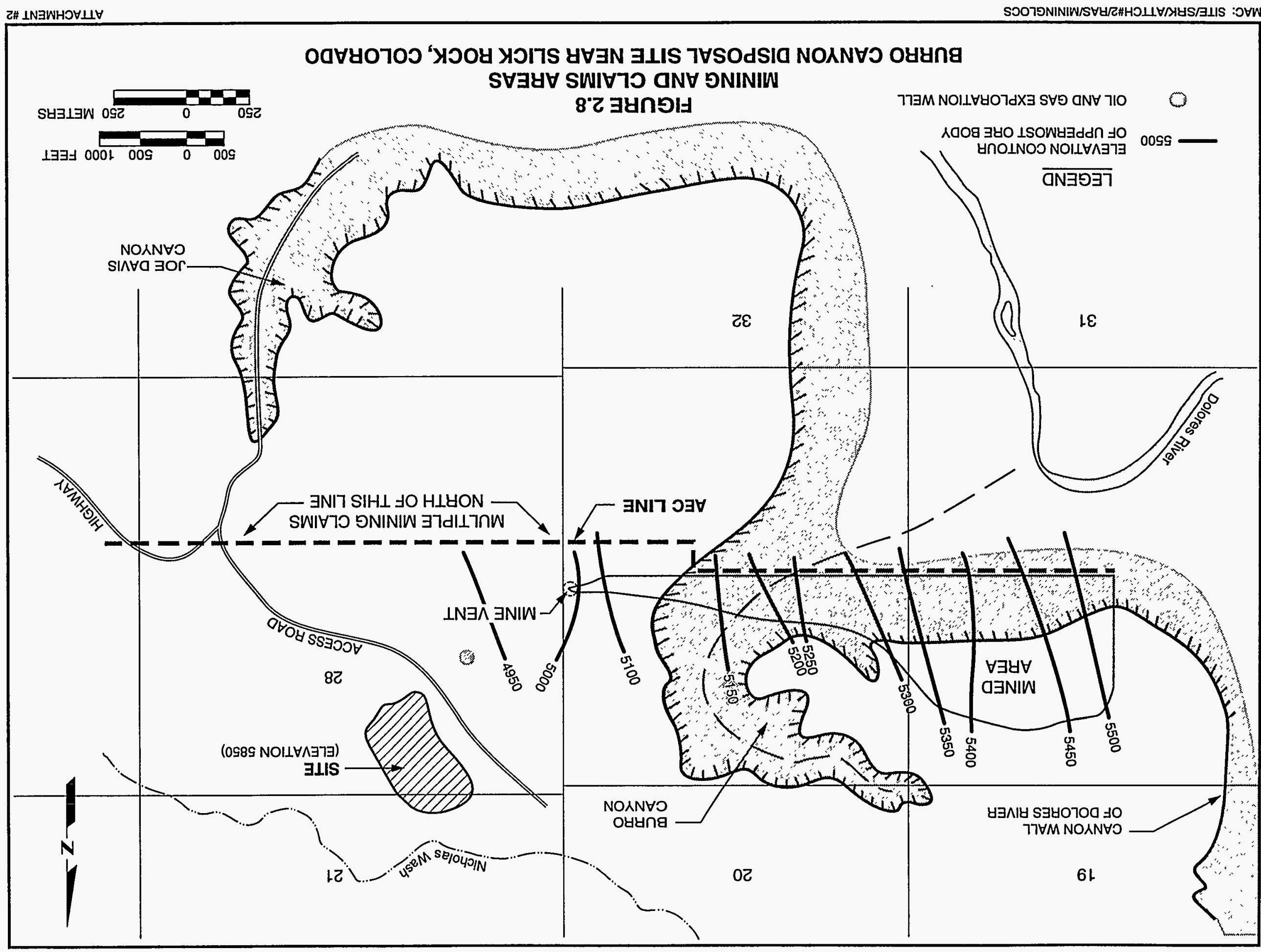


Egnar-Gypsum Valley area (Stokes and Phoenix, 1948). No known economic oil or gas deposits occur in the area of the Burro Canyon disposal site, although exploration has occurred adjacent to the site. The mine vent shown on Figure 2.8 is erroneously shown on U.S. Geological Survey (USGS) topographic maps as an "oil" or "gas well." Numerous seismic lines for hydrocarbon exploration have been done within the folded belt, particularly around the collapsed anticline structures. This is expected to include the alignment of the access roads and trails immediately adjacent to and across from the disposal site.

Section 5.4 discusses the potential impact on the site of developing unexploited natural resources in the area. The locations of exploration for oil and gas or other resources in the region are poorly known because the data are confidential and have not been shared with the Bureau of Land Management (BLM) or the county; these agencies defer any such queries to the companies that have been in the area. The BLM reports an abandoned gas well that penetrated to a depth of $9402 \mathrm{ft}(2866 \mathrm{~m})$ just west of the site is typical of exploration in the area.

Thin coal seams and carbonaceous shale occasionally are present in the Dakota Sandstone Formation but do not underlie the site. These deposits are impure and discontinuous and do not contain economically important coal reserves.

Although very minor amounts of metallic minerals occur with the uraniumvanadium ores, their low concentration precludes economic development (Shawe et al., 1959). No known potential development of geothermal heat exists in the disposal site area.

Potash occurs with the Paradox Salt Member of the Pennsylvanian-aged Hermosa Formation. The only known production is in the Moab, Utah, area outside the site region, although nearly all the basin within this region could have potash deposits (Figure 2.5). Conventional mining procedures were used until 1970, when solution mining was adopted to avoid problems associated with salt flow in deep tunnels (Wong et al., 1987). A study by WoodwardClyde Consultants (W-C, 1983) showed most commercial mining zones are below $2500 \mathrm{ft}(760 \mathrm{~m})$ but are known to occur from 430 to $10,000 \mathrm{ft}(690$ to $3000 \mathrm{~m}$ ) or more. The current economic cutoff depth is approximately $4000 \mathrm{ft}$ $(1200 \mathrm{~m})$ because of salt flow. Some mining-induced seismicity has occurred near the Utah operation.

Mineral associated with natural brines in the Paradox Basin could be important for several metals. Most natural brine occurrences are too small for economic development; however, some artificial brines (by solution mining) are produced in the Moab, Utah, area (W-C, 1983). 


\subsection{SITE GEOLOGY}

\section{General geologic setting}

The Burro Canyon disposal site is named after nearby Burro Canyon, a steep-walled tributary canyon to the Dolores River Canyon. The Burro Canyon Formation was also named after the exposure of this strata in the canyon. The formation at this location, however, is different from most other outcrops in the region and its lithologic occurrence is not useful as a type section (Shawe et al., 1968).

The site is near the axis of the Disappointment syncline at the northwest end of Disappointment Valley. The synclinal axis plunges southeast toward the center of the valley. The Mancos Shale Formation of Cretaceous age, the youngest bedrock in the region, is exposed on the surface in the lower part of the valley but is completely eroded from higher elevations, including the site area. The resistant Dakota Sandstone forms the cap rock around the perimeter of the synclinal valley (Figures 3.1 and 3.2).

The nearby Dolores River is a meandering stream, which was established on the soft rocks of the thick Mancos Shale or perhaps on overlying poorly consolidated Tertiary sediments. During regional uplift and folding, the stream was superimposed and entrenched across the folded belt without noticeable structural or stratigraphic controls. Because of the erosional resistance of various sandstone strata, all other topographic features in the area strongly reflect the structure of the Dolores anticline and the Disappointment syncline.

\section{$3.1 \quad$ BEDROCK GEOLOGY}

Figures 3.1 and 3.2 show the bedrock in the Burro Canyon disposal site area. Figures $3.3,3.4,3.5$, and 3.6 show cross sections of the stratigraphy below the site. The full stratigraphic section is shown in Figure 2.3 and described in Table 2.1.

The lowest unit of the Dakota Sandstone forms the foundation for the site. This lower unit is a black carbonaceous shale and mudstone that contains two persistent thin sandstone layers. Shawe et al. (1968) observe that locally this layer is in conformable contact with the uppermost unit of the Burro Canyon Formation. The carbonaceous shale underlies the main sandstone unit of the Dakota Sandstone and is exposed on the eastern edge of the site, where it is moderately to severely weathered. The shale appears suitable for clean fill borrow material and offers a potential for geochemical attenuation of contaminant constituents. Locally, some lateral facies change from black shale to greenish-brown mudstone in the lower part of this unit.

The main sandstone unit ( $\mathrm{Kd} 3$ ) forms the upper part of the formation and occurs as eroded outcrops on the ridge at the southeast side of the disposal site and along the north edge of the mesa. Its maximum thickness on the ridge is about $16 \mathrm{ft}(4.9 \mathrm{~m})$. 


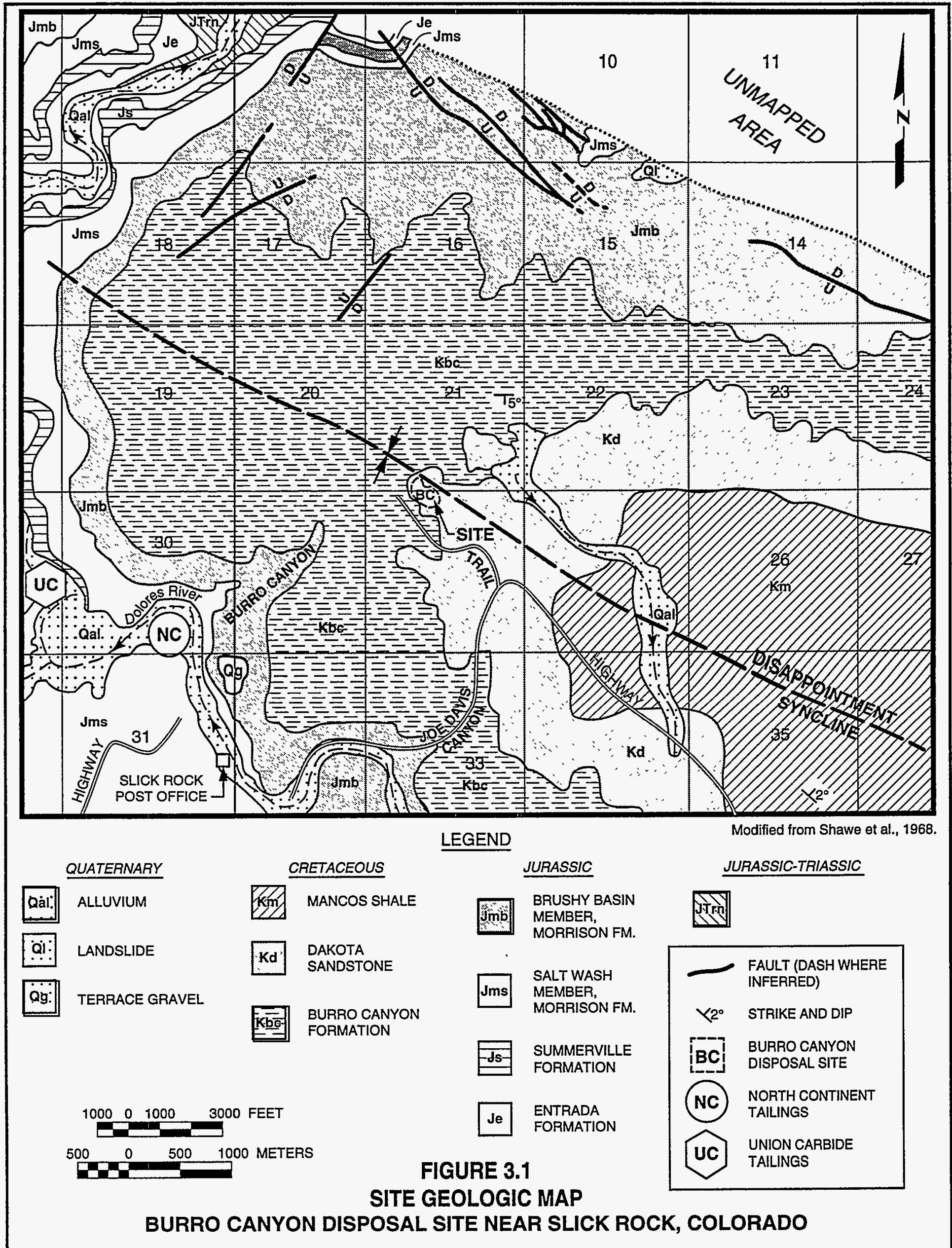




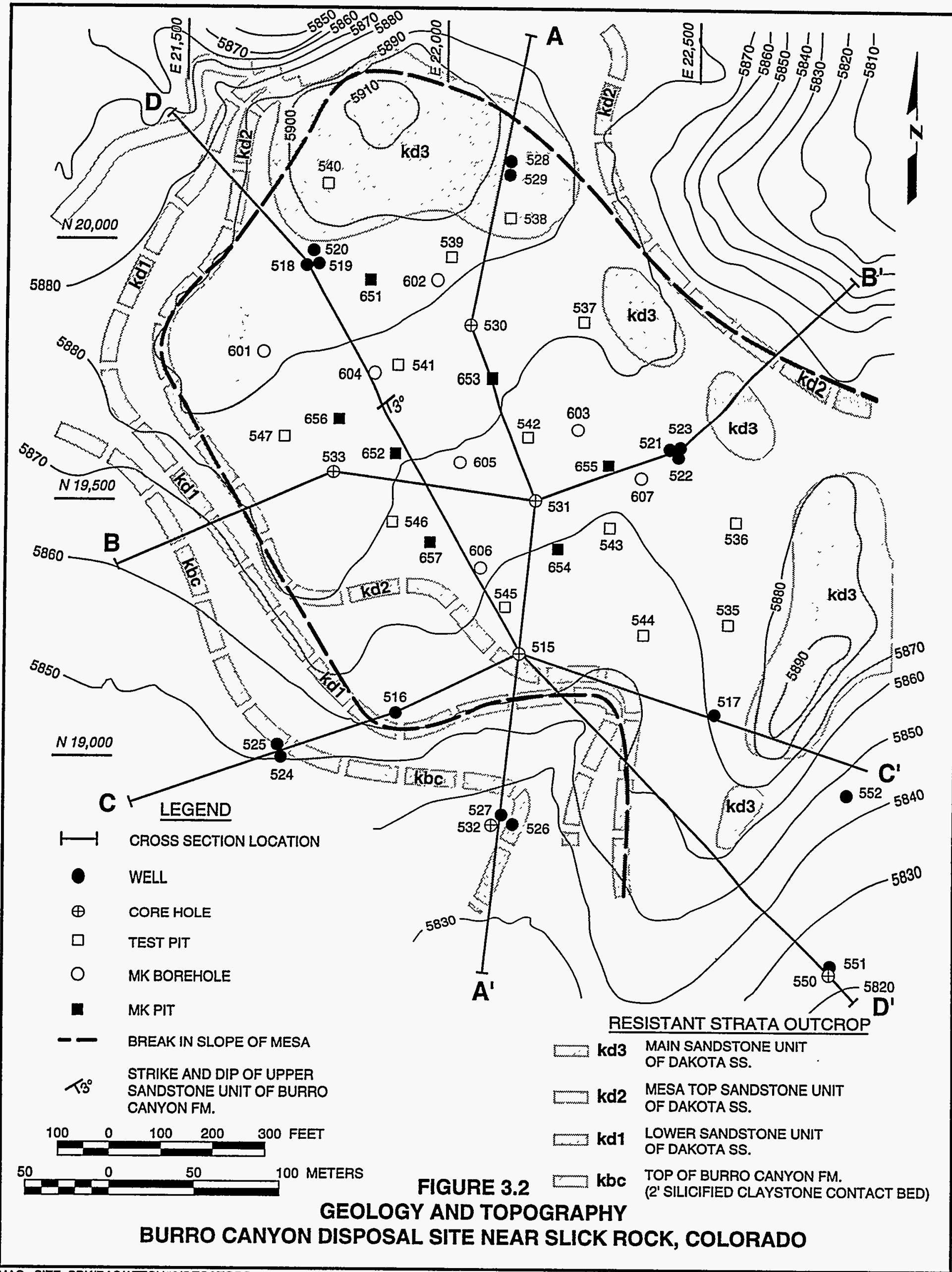




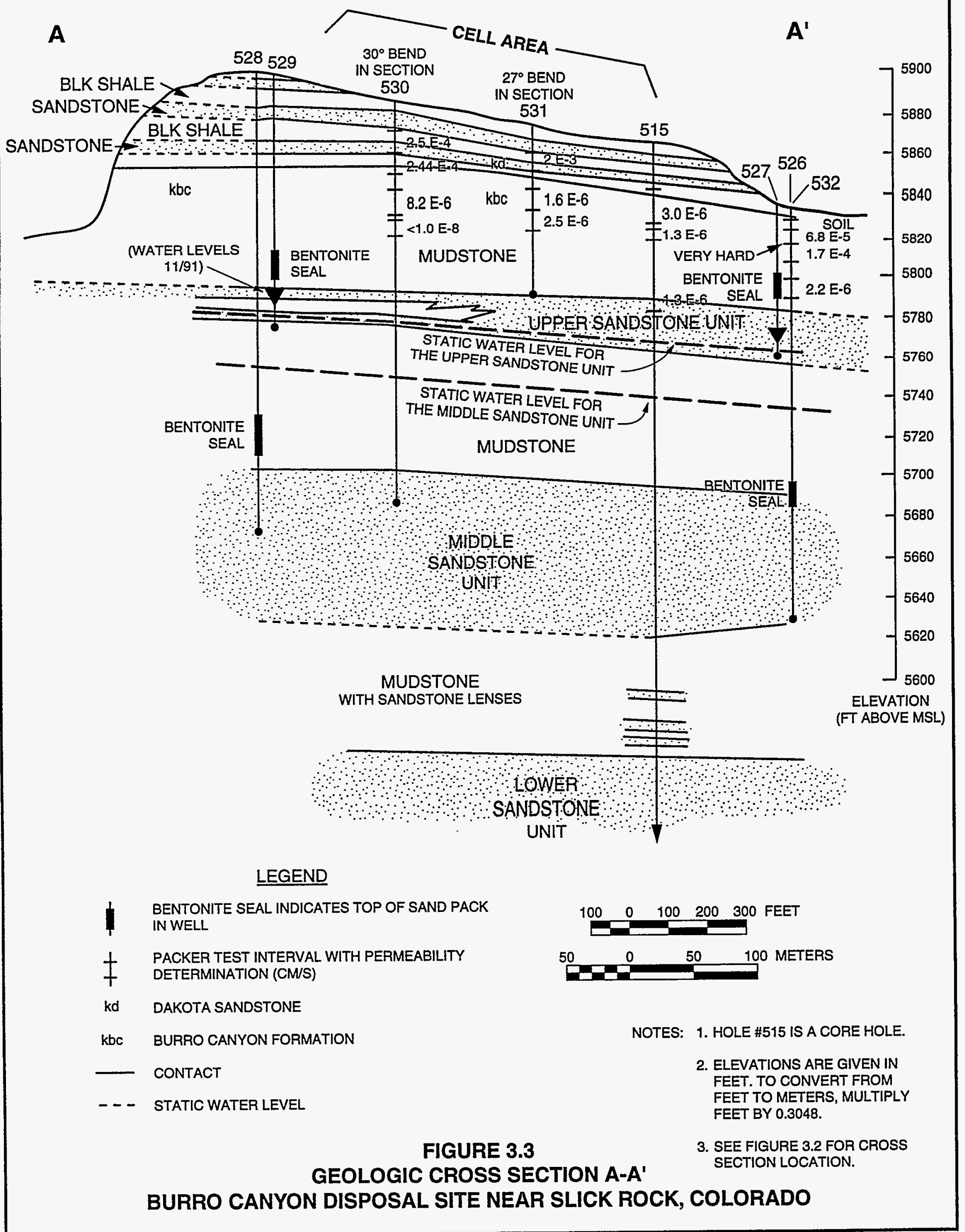


B
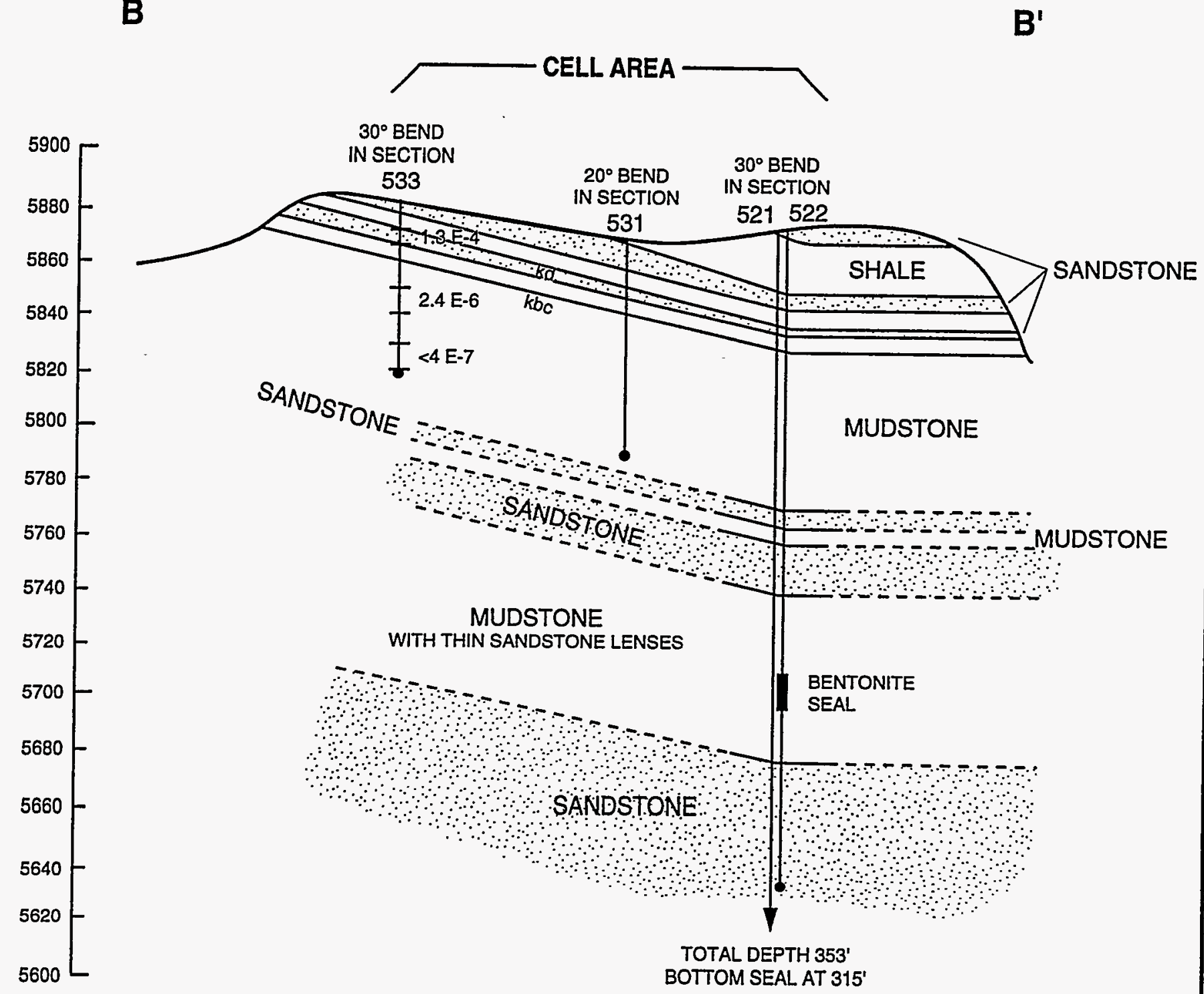

ELEVATION

(FT ABOVE MSL)

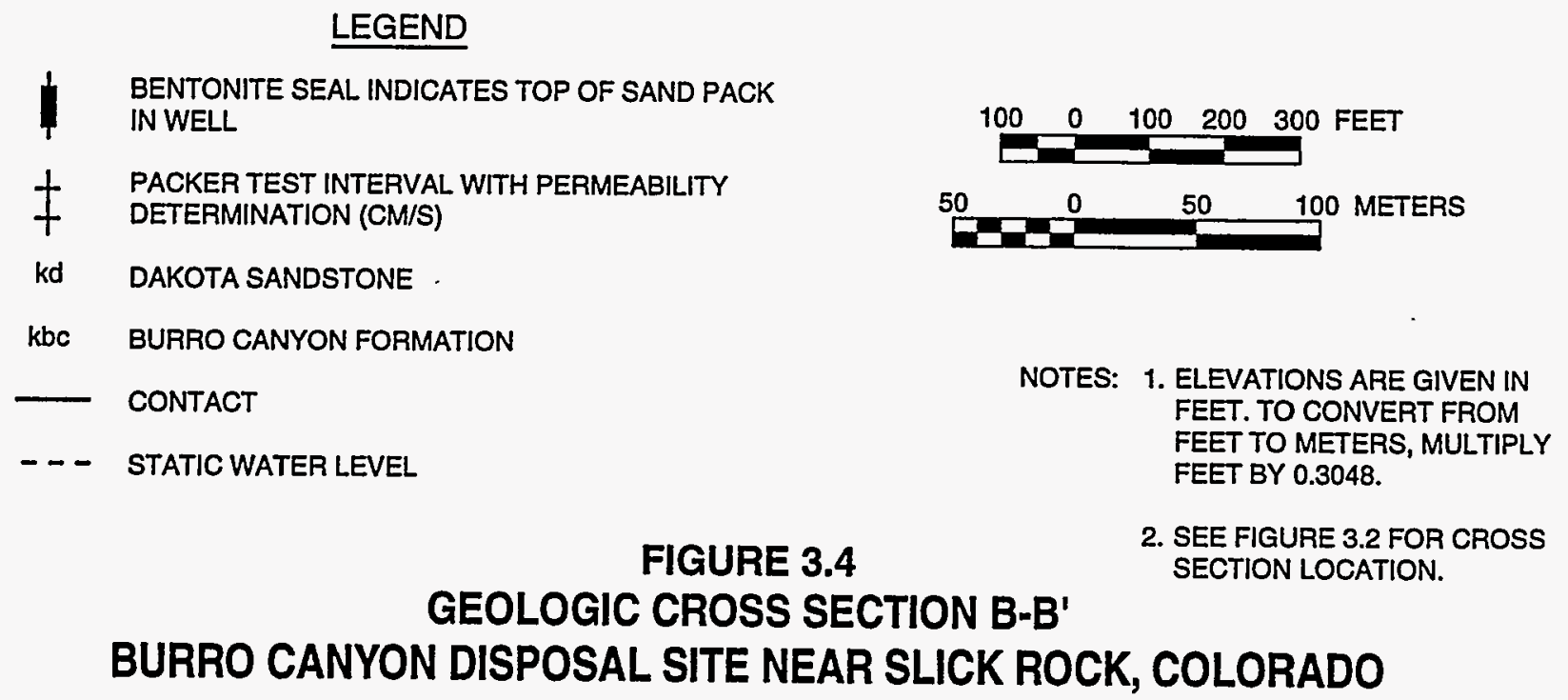




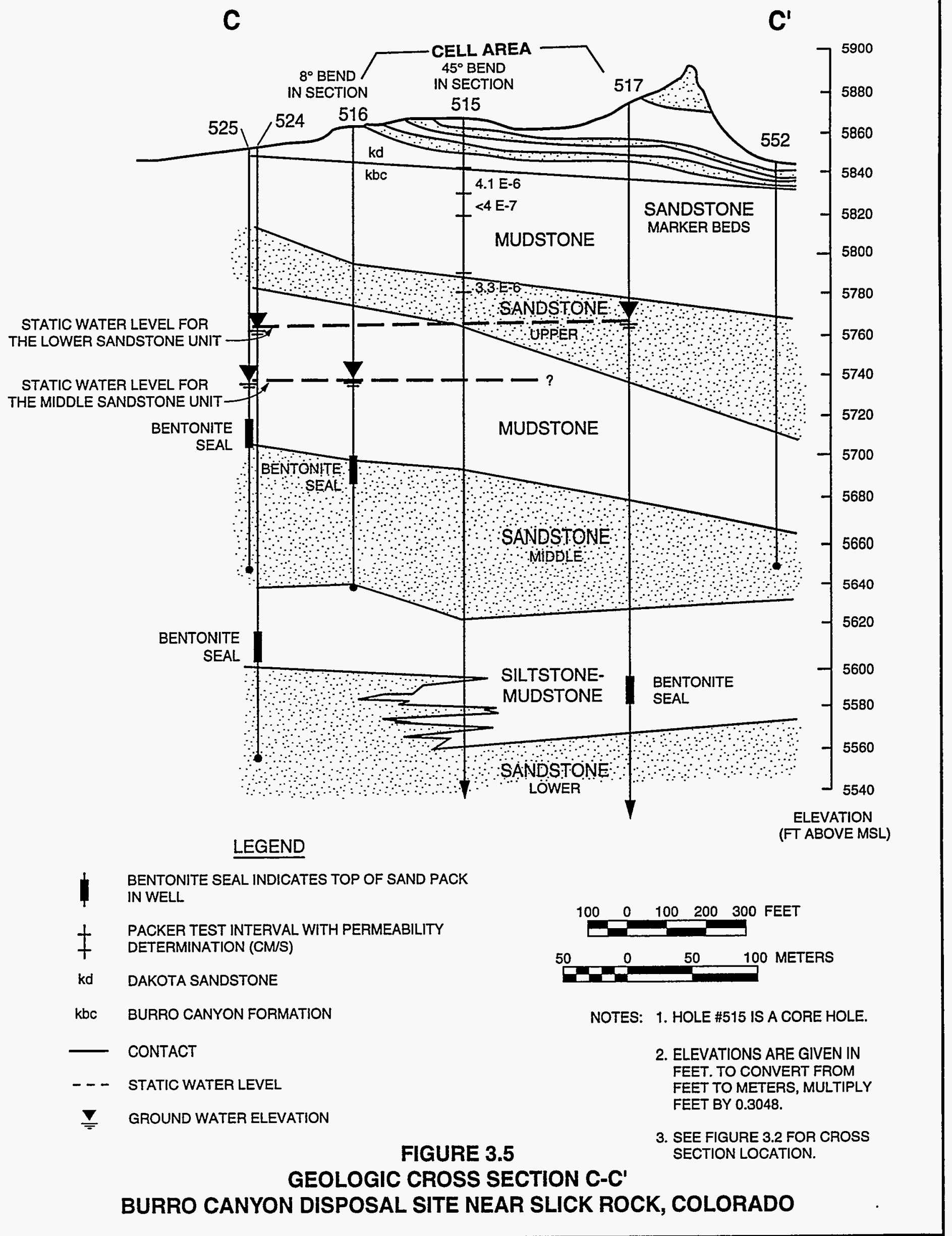




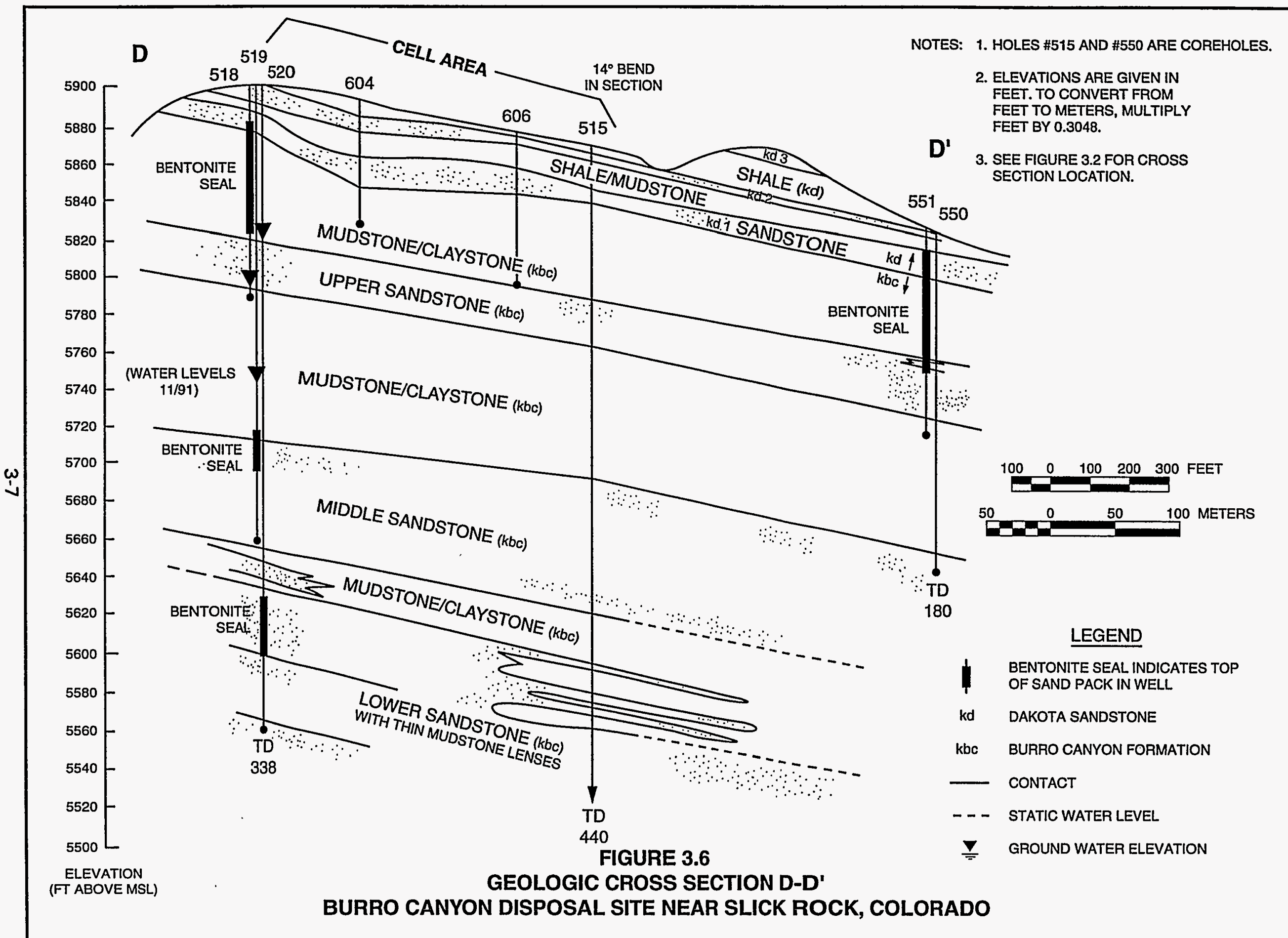


The two thin sandstone layers ( $\mathrm{Kd} 2$ and $K d 1$ ) of this lower unit of the Dakota Sandstone and the underlying silicified claystone of the Burro Canyon Formation at the upper contact form the resistant rim rock of the small mesa on which the site is located. The thin sandstone strata vary from 1 to $6 \mathrm{ft}(0.3$ to $2 \mathrm{~m})$ thick and the resistant silicified mudstone of the Burro Canyon contact zone is typically $2 \mathrm{ft}(0.6 \mathrm{~m})$ thick. These thin Dakota Sandstone units occur in the upper 5 to $10 \mathrm{ft}(2$ to $3 \mathrm{~m})$ of the mesa surface and the upper (Kd2) unit was excavatable in most cases with a small backhoe.

The claystone of the Burro Canyon Formation is gray-green to blue-green in contrast to the drab yellow, browns, and dark gray of the Dakota Sandstone. In the steep slopes of the north and east sides of the mesa, the silicified contact bed of the Burro Canyon Formation appears distinctive in its color and strong resistance to undercutting erosion. In some areas below the site, however, the contact appears to be more gradational and less defined in borehole data.

Shawe et al. (1968) report the top of the Burro Canyon Formation is called a marker bed in this area because of its conspicuous outcrop and lateral persistence, describing it as a light greenish-gray stratum 1 to $3 \mathrm{ft}(0.3$ to $1 \mathrm{~m})$ thick that appears to be a silicified silty claystone. It is chert-like in some places. The rock contains numerous calcite crystals $1 \mathrm{~mm}$ in size, and contains kaolinite. This nonswelling clay differs from the bentonitic clay that characterizes the underlying Brushy Basin Member of the Morrison Formation (Shawe et al., 1968).

The upper $60 \mathrm{ft}(18 \mathrm{~m})$ of the Burro Canyon Formation and the lower $40 \mathrm{ft}$ $(12 \mathrm{~m})$ of the Dakota Sandstone are exposed continuously around the north face of the mesa in the tributary of Nicholas Wash. The exposure shows the very gentle dip and the unfaulted structure of the mesa.

The upper claystone/mudstone unit of Burro Canyon Formation ranges from 50 to $65 \mathrm{ft}(15$ to $20 \mathrm{~m})$ thick. Packer test permeability determinations (shown in cross section, Figures 3.3 through 3.5 ) and core analysis indicate this hydrologically confining unit is only moderately weathered with few fractures and is essentially impermeable in the lower two-thirds of the claystone unit. Attachment 3, Ground Water Hydrology Report, assesses this important unit.

The Burro Canyon Formation contains three sandstone/conglomerate units. The tops of these units are approximately 100, 200, and $300 \mathrm{ft}(30,60$, and $90 \mathrm{~m})$ below the site. The upper sandstone unit contains a partially saturated, low-yield water table, whereas the middle and lower units are fully confined artesian aquifers. Details of these units are discussed in Attachment 3. Shawe et al. (1968) report that some areas of Disappointment Valley contain as many as six distinct sandstone units within the Burro Canyon Formation. The intervals between the sandstone consist of strata of claystone and mudstone. The upper part of the formation contains thin, interbedded limestone and both silica and calcite cement occur in the sandstone units. The silica cementation of the sandstone in some cases has altered it to quartzite (Shawe, 1968). 
Logs of on-site core holes show Burro Canyon Formation below the site is 400 $\mathrm{ft}(120 \mathrm{~m})$ thick. Shawe et al. (1968) report this location has one of the thickest sections in the region and gives a combined thickness of the Burro Canyon and the Brushy Basin Member of the Morrison Formation as 850 to 900 $\mathrm{ft}(260$ to $270 \mathrm{~m})$. This thickness is significant because it marks the relative depth of the uppermost uranium-vanadium ore zone at the top of the Salt Wash Member of the Morrison Formation.

The upper and lower portions of the Morrison Formation are composed, respectively, of the Brushy Basin and the Salt Wash Members. 'The Brushy Basin Member consists mostly of thick units of mudstone interbedded with thin discontinuous sandstone units. The bentonitic clays in this formation form unstable slopes in the oversteepened river valley (Shawe et al., 1968).

The upper zone of the Salt Wash Member is the primary uranium-vanadium oreproducing stratum in this region; it outcrops along the Dolores River floodplain near Slick Rock, Colorado. Ore values in the exploration core holes for the Burro Canyon mines approximately $0.5 \mathrm{mi}(0.8 \mathrm{~km})$ west of the disposal site occur only within this zone (Figure 2.8 ).

\section{Bedrock structure}

Figure 2.5 shows the structure of the Disappointment syncline and the relationship to the salt core anticline within Paradox Basin. Based on strikes and dips shown on Figure 3.2, the beds dip approximately 2 to 3 percent (1 degree) southeast below the site. The ground water in each of the three sandstone units in the Burro Canyon Formation flows in slightly different southerly directions (see Attachment 4, Water Resources Protection Strategy).

\subsection{SURFICIAL GEOLOGY}

Several drill holes and 20 test pits in the disposal site area indicate the soils consist of reddish-brown, sandy clay to clayey sand ranging from 0 to $1.5 \mathrm{ft}$ $(0.5 \mathrm{~m})$ thick at the perimeter of the mesa top to 3 to $4.5 \mathrm{ft}(1$ to $1.4 \mathrm{~m})$ thick in the middle of the site. In most instances, the soil was found to be directly underlain by a thin sandstone stratum. In a few locations, the soil was underlain by a dark-gray, carbonaceous shale/claystone.

Figure 3.7 shows the surficial geology map of the site area; Figure 3.2 shows the resistant rocks that outcrop on the site. The area north of the site is deeply incised by tributaries of Nicholas Wash and contains only thin Quaternary deposits within the confines of active drainages (Figures 3.7 and 3.8).

\subsection{GEOMORPHOLOGY}

The small mesa on which the site is located is isolated from upland runoff. Figure 3.8 shows the site basin relative to adjacent basin and drainage systems. The drainage north and east of the site is the Nicholas Wash Basin, trending 


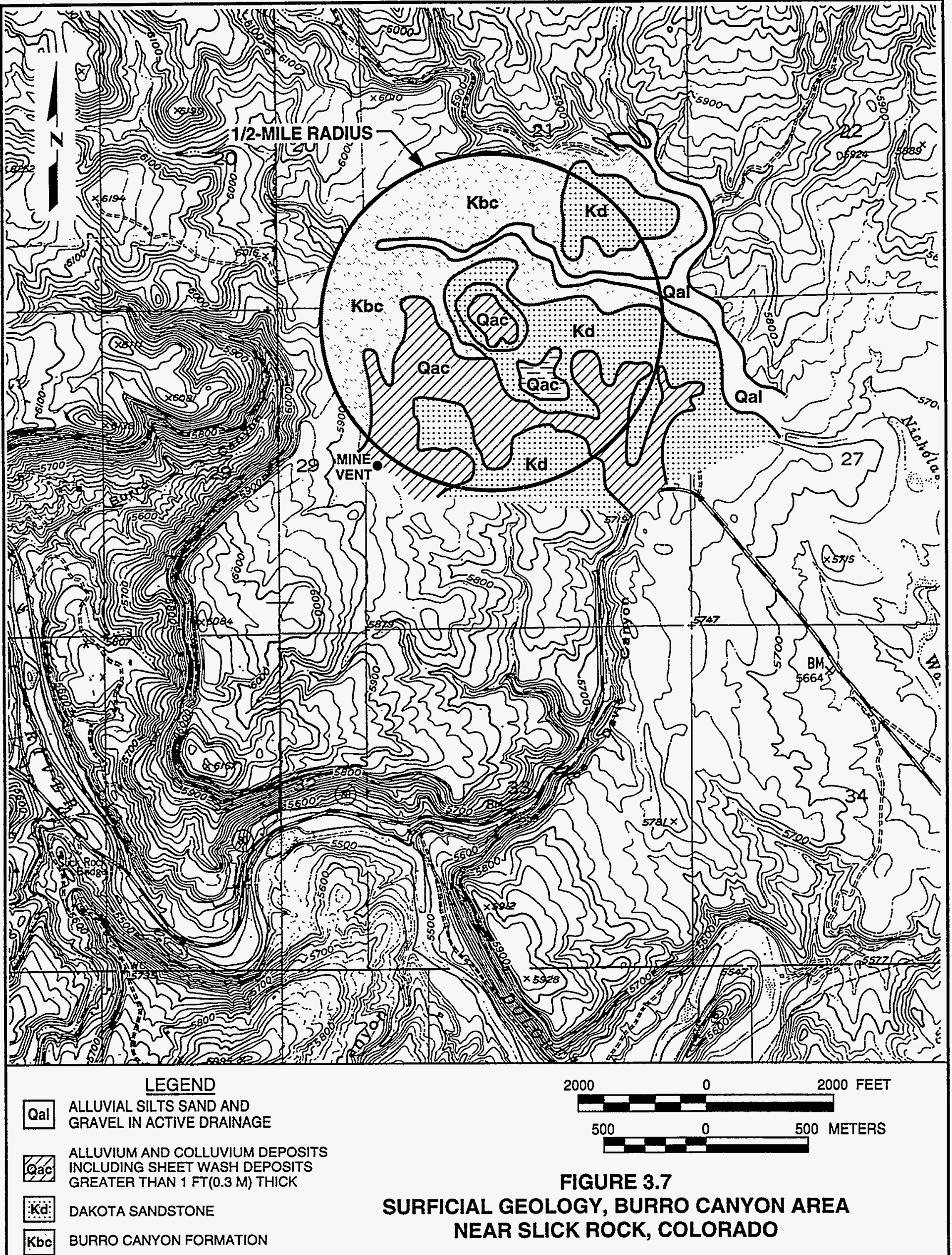




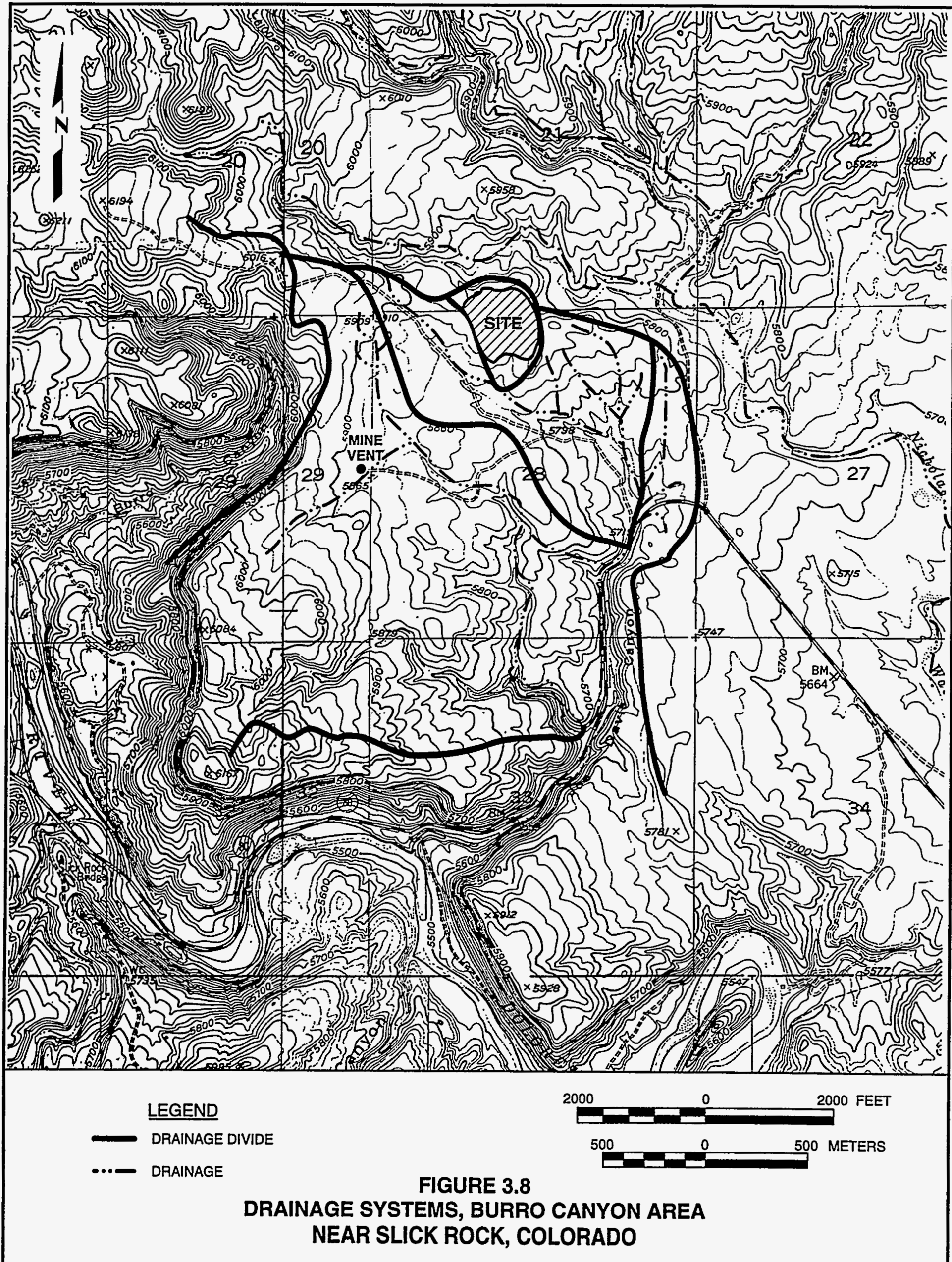


along the axis of Disappointment Valley. The site and basins south of the site drain into Joe Davis Canyon. The site has two shallow drainages through the mesa center that drain by sheet flow until reaching the south edge of the mesa; there the flow concentrates into a well-defined gully where it incises the rim (Figure 3.2). The rim of the mesa on the west and north sides is also the drainage divide.

The soil-covered mesa top has a moderate cover of grass. Scattered juniper trees occur at the rim where sandstone outcrops. The average slope of the basin is approximately 0.033 feet per foot $(\mathrm{ft} / \mathrm{ft})$. The slopes below the rim of the mesa range from $0.145 \mathrm{ft} / \mathrm{ft}$ on the north slope, $0.118 \mathrm{ft} / \mathrm{ft}$ on the west slope, and $0.20 \mathrm{ft} / \mathrm{ft}$ on the south slope. Where the drainage exits the mesa on the south slope, the channel slope is $0.100 \mathrm{ft} / \mathrm{ft}$ (Figures 3.2, 3.7, and 3.8). Sandstone bedrock is exposed in this drainage, which also is armored with sandstone fragments. The erosion rate in the channel is low; there are no active gullies. The steeper slopes below the mesa rim on the south and southwest sides are covered with a thin veneer of colluvium composed mostly of detritus from the weathering of the two thin sandstone strata. Sandstone fragments from a few inches to slabs several feet across form a natural armor on the slopes, particularly at the head of minor gullies. The armor sustains a thin soil development and vegetation growth. Except for the outcrop of the sandstone, there are few bedrock exposures on the upper slopes.

The controlling influence in the development of geomorphic features at the site is the differential erosion of the claystone and shale units above and below the resistant rimrock contact strata of the Burro Canyon Formation and Dakota Sandstone. The erosion of most of the $60-\mathrm{ft}(20-\mathrm{m})$ thick claystone and mudstone of the upper Burro Canyon Formation creates the relief of the mesa on which the site is located.

The upper sandstone unit of the Burro Canyon Formation is a silica-cemented quartzite that forms the floor of the broad valley west of the site. This unit also forms the bottom of the Nicholas Wash tributary drainage just north of the site.

The western slope below the edge of the mesa has the least thickness of sandstone rimrock. At the southeast corner of the mesa top, the upper of the two thin sandstone strata is missing from a 1-acre (0.4-hectare) area (Figure 3.2). On the north, east, and southeast edges of the site, the $\mathrm{Kd} 2$ sandstone unit of the Dakota Sandstone, which is up to $16 \mathrm{ft}(4.9 \mathrm{~m})$ thick in the southeast ridge, provide stability to the mesa edge and stabilize the slopes of the arroyo downslope from the site (Figures 3.3 through 3.6).

The Dakota Sandstone has been eroded from most of the area north of the Nicholas Wash tributary bordering the site. Small mesa tops in that area are capped by the silicified upper contact bed of the Burro Canyon Formation, which is resistant to gully formation (Figures 3.1 and 3.6). 
The nonswelling type of clay and the silica-altered cementation that characterizes the mineralogy of the Burro Canyon Formation (Shawe, 1968; Shawe et al., 1968) give the mudstone a resistance to erosion that is significantly greater than that of similar claystone-mudstone units in the Mancos Shale Formation, Dakota Sandstone, or Morrison Formation exposed in the area. 


\subsection{GEOLOGIC STABILITY}

4.1

\section{GEOMORPHIC STABILITY}

The principal geomorphic processes in the site area are scarp retreat, reentrant penetration of tributaries into the bedrock mesa, and surficial erosion of soils. The rim of the mesa where the disposal site will be located has exposed bedrock around most of the full perimeter of the site (Figure 3.2). This rim marks the drainage divide between the mesa top and sideslopes. With no erosion potential from overland flow, the age of the mesa scarp is based on the rate of scarp retreat for the region. The age can be ascertained only in relative terms because retreat is dependent on the resistance of the outcropping formation. With rates presented in Section 2.1 ranging from 0.8 to $1.8 \mathrm{ft}(0.2$ to $0.55 \mathrm{~m}) / 1000$ years for some studies (Schumm and Chorley, 1966; Haman, 1983) to $74 \mathrm{ft}$ $(23 \mathrm{~m}) / 1000$ years in another study (Hunt, 1969), it can be concluded that retreat has been in the lower range of these rates and the site has been geomorphically stable for the last 1000 years.

Potential hazards for the long-term stability of the site are 1) tributary headcutting below the site if the cell extends south beyond the physical protection of the rimrock, and 2) runoff from the cell cover diverted over the edge of the mesa rim will expose the lower slopes to concentrated flow. The $100-\mathrm{ft}(30-\mathrm{m})$ setback zone around the perimeter will require protection of the integrity of the cap rock with drainage control channels and stabilized aprons above and below the rimrock.

Flooding is not a concern, based on the $80-\mathrm{ft}(25-\mathrm{m})$ height of the mesa above the north side tributary system of Nicholas Wash.

\subsection{SEISMOTECTONIC STABILITY}

\section{Technical approach}

The objectives of the seismic hazard analysis performed for this study are as follows:

- Select the design earthquake and estimate the on-site PHA for use in subsequent engineering analyses.

- Recognize any potential for on-site fault rupture.

- Recognize any potential for earthquake-induced landsliding or subsidence due to tectonic causes.

The technical analysis performed for this study involved a critical review of all the information developed during the investigation and a step-by-step approach to estimating seismic risk. 
The first step was the determination of the magnitude of the FE in the seismotectonic province within which the site is located. This earthquake was assumed to occur at a radial distance of $9.3 \mathrm{mi}(15 \mathrm{~km})$ from the site. The resulting on-site acceleration was calculated using the acceleration/attenuation relationship of Campbell (1981) and Campbell and Bozorgnia (1994) as discussed in the TAD (DOE, 1989; Keaton 1994a; 1994b). The adaptation of the threshold event $(M=6.2)$ at this distance is discussed in Section 1.1 of this attachment.

The analysis above was followed to determine the maximum on-site acceleration resulting from maximum magnitude earthquakes occurring in each of the other seismotectonic provinces within the region of interest. Individual faults within other provinces were not analyzed unless they lay within a $65-\mathrm{km}$ radius of the disposal site. In a conservative approach, the provinces closest to the site were measured first. The measurements were made using published maps and literature to delineate province boundaries. The estimated ME values for these other provinces were based on published studies and personal communication with researchers active in the area. The ME then was assumed to occur at the closest approach from each of these provinces to the disposal site, and the resulting on-site acceleration was calculated.

After completing the first two steps in the analysis, the on-site accelerations resulting from the FE within the province containing the disposal site were compared to the MEs from the closest approach of each of the other provinces. The largest value was taken as the critical acceleration during the subsequent capable fault analysis.

Based on the review of published and unpublished geologic data and the air-photo analysis, all mapped faults and air-photo lineaments within a radial distance of $65 \mathrm{~km}$ of the site were compiled. For faults of tectonic origin, the fault length/magnitude relationships of Bonilla et al. (1984) were used to determine the ME that each structure would produce if it were determined to be a capable fault. An on-site acceleration resulting from each fault was then calculated. These values were compared to the critical acceleration determined during the previous analysis. Any features potentially capable of producing a larger on-site acceleration than the critical value were subjected to a detailed field investigation to determine if they were capable faults.

The capable fault investigation consisted of the analysis of the seismic record for evidence of micro- and macroseismicity associated with the fault, close inspection of the mapped fault trace on aerial photography, detailed ground reconnaissance for evidence of Late Quaternary or Holocene movements, and careful investigation of the indicated fault during the LSA aerial reconnaissance.

If any evidence indicated that a fault is capable, the largest calculated on-site acceleration was recommended as the design acceleration value. The fault was designated as the controlling fault and the ME on that fault was specified as the design earthquake. 


\section{Previous studies}

Several probabilistic earthquake maps, which plot contours of maximum horizontal accelerations, velocities, and intensities for various return periods, have been prepared for the contiguous United States. Examples of such studies are those by Liu and DeCapua (1975), Algermissen and Perkins (1976), the Applied Technology Council (ATC) (1978), and Algermissen et al. (1982). These studies were used to estimate the maximum value of each parameter for the disposal site area. The resulting values are listed in Table 2.3.

Accelerations calculated in these previous studies are uniformly lower than the maximum values derived from this RAP. Previous studies are probabilistic analyses based on the rather brief historical record.

\section{Fault and epicentral compilation}

A compilation of all mapped faults and earthquake epicenters within $40 \mathrm{mi}$ $(65 \mathrm{~km})$ of the sites is shown in Plate 2.1 of this document. In addition, all suspected faults and lineaments derived from aerial photographic interpretation were compiled. All faults and lineaments were observed at least once during the LSA aerial reconnaissance. Most features within $12 \mathrm{mi}(19 \mathrm{~km})$ of the site were field-checked during the ground reconnaissance phase of this RAP. Other features of regional significance outside this $12-\mathrm{mi}(19-\mathrm{km})$ radius were also field-checked.

Most of the faults within a $65-\mathrm{km}$ radius of the site are associated with collapsed salt-cored anticlines. The faults of salt anticline collapse structures are nontectonic features that are considered active. Slow creep may be occurring on some of these faults as subsurface evaporite bodies continue to be removed by solutioning. Faults within the salt anticline region Kirkham and Rogers (1981) identified as potentially active are associated with the collapse of anticline crests.

Fault swarms along the southwest side of the Uncompahgre Plateau lie within the northeast part of the $65-\mathrm{km}$ radius of the site (Plate 2.1). The Uncompahgre Uplift may be an active seismotectonic feature. Geologic and geomorphic evidence indicates the uplift has been a recurrently active feature since Late Paleozoic time, and may have experienced considerable uplift since Late Pliocene time (Cater, 1966; Sinnock, 1981 b; Kirkham and Rogers, 1981). Kirkham and Rogers (1981) identified many faults as potentially capable. Regional seismic trends (Figure 2.6) also indicate the uplift has been the focus of a low-to-moderate level of seismicity during historical time. Ely et al. (1986) associated a magnitude 2.9 earthquake with one of the faults in the uplift. The most conservative approach is to consider all faults in the uplifts as capable.

All faults and linear features observed during the study are discussed briefly in Table 4.1 and are shown on Plate 2.1. Faults for which the estimated on-site acceleration (resulting from the estimated $\mathrm{ME}$ ) approached or exceeded the 


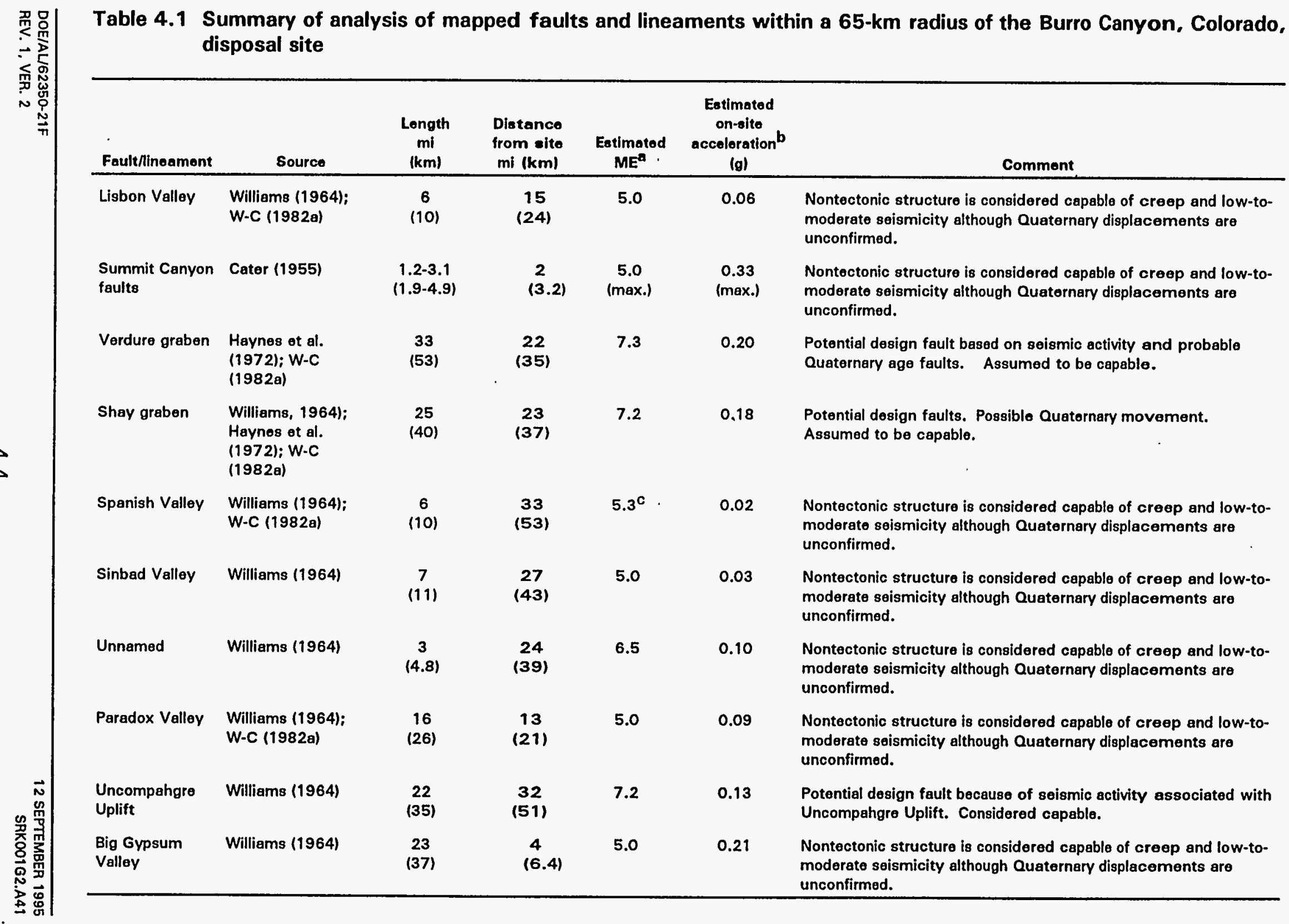




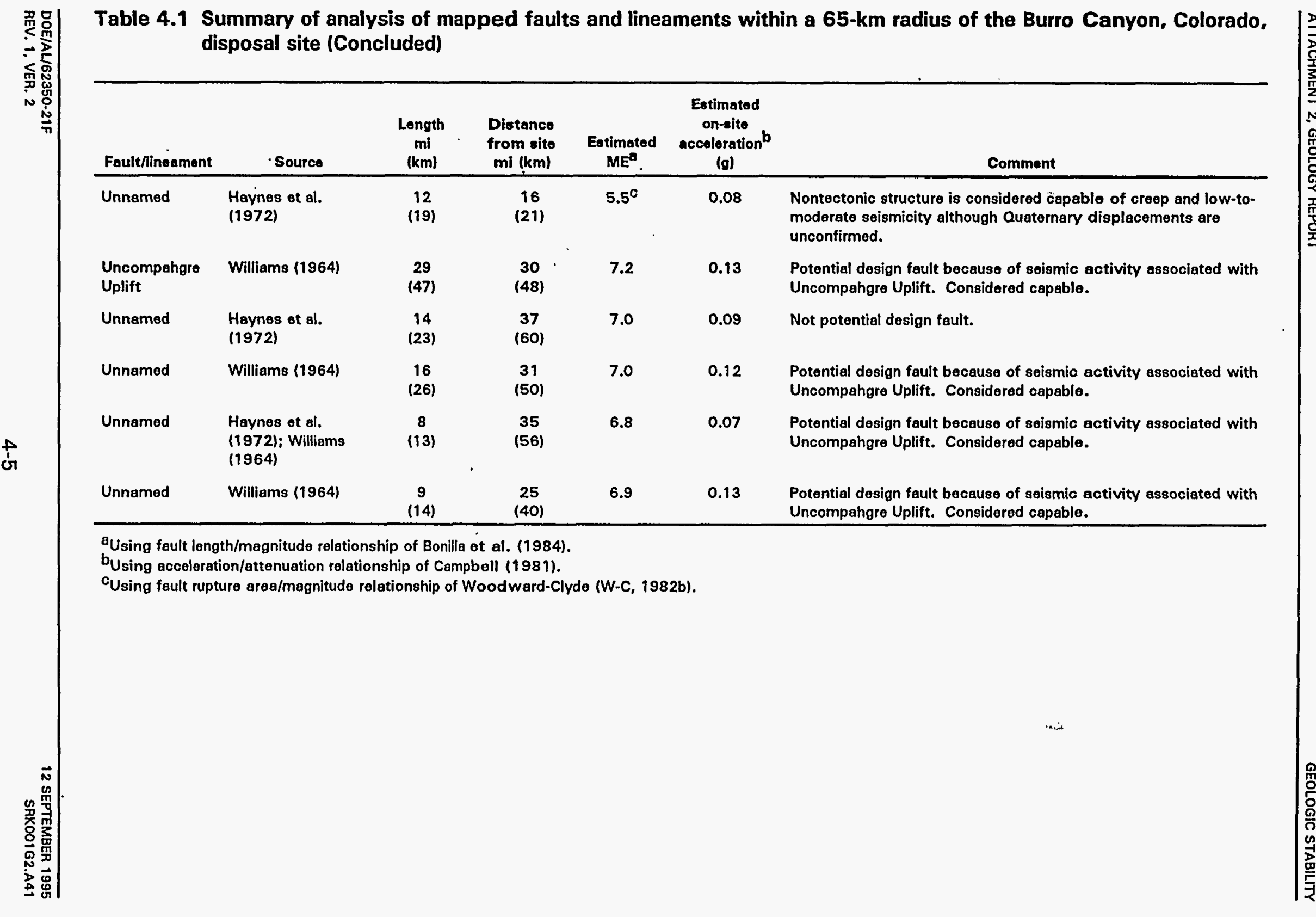


acceleration of $0.21 \mathrm{~g}$ (resulting from FE) were subjected to critical analysis. Fault segments with reported or suspected Quaternary movement were examined in the field.

These include fault groups numbered $1,1 \mathrm{~A}, 7,9$, and 10. The faults initially determined to be the most critical for design potential are those of the $1 \mathrm{~A}$ group and fault groups 1 and 9 . Fault groups 2 and 3 are discussed because probable Quaternary movement has occurred along segments of their surface traces. Fault groups 8 and 11 are related to uplift of the Uncompahgre Plateau and may be capable but do not have on-site accelerations in excess of the design value.

Fault group 1. This fault zone is mapped as parallel fault segments trending along the crest of the Lisbon Valley salt-cored anticline (Williams, 1964). Major valley-bounding faults extend to within $15 \mathrm{mi}(24 \mathrm{~km})$ of the site. Shorter bedrock faults of the southeast end of the valley extend to within about $0.6 \mathrm{mi}$ $(1 \mathrm{~km})$ of the site. All faults are related to the collapse of the anticline crest following solutioning and removal of subsurface evaporite bodies. The Lisbon Valley-Moab fault zone probably experienced northeast-side-down displacement during the Pliocene and possibly Quaternary (W-C, 1982a). Earthquake monitoring (W-C, 1982a) in the vicinity of the Lisbon fault detected no microearthquakes with magnitudes greater than $M_{L}=1.0$. The absence of microearthquake activity, however, does not necessarily indicate the structure is inactive. LSA reconnaissance over the structure showed no visible evidence of Quaternary displacement in the valley fill deposits. Detailed field inspection also revealed no surface evidence of fault displacement, but for this analysis the structures in this group are considered active. The fault group is considered of nontectonic origin. Any movement along salt anticline collapse fault surfaces would likely occur by slow creep, as previously discussed. Sudden fault shear activity along the entire length of the fault zone is not consistent with the geologic evidence of past fault movement.

Fault group 1A. Faults in group 1A are mapped on the Horse Range Mesa 7.5-minute geologic quadrangle map (Cater, 1955). Mapped faults up to $3 \mathrm{mi}$ $(5 \mathrm{~km})$ long occur within about $4 \mathrm{mi}(6 \mathrm{~km})$ of the site area. Based on fault lengths within this group, the estimated on-site accelerations for tectonic fault are greater than the design acceleration of $0.21 \mathrm{~g}$; however, the faults appear to be related to the formation and collapse of the Lisbon Valley salt-cored anticline to the northwest and are nontectonic. Fault displacement increases toward the collapsed anticline and decreases to extinction entering Summit Canyon. LSA reconnaissance and ground inspection revealed no offset of surficial units. No faults in rock units younger than Cretaceous age were located, but for purpose of this analysis, faults were considered as presently active.

Fault groups 2 and 3 . Both these faults are associated with the Abajo Mountain igneous intrusion. Doming of the Abajo Mountain area resulted in initial formation of the Verdure and Shay grabens during the Oligocene. Geomorphic evidence suggests parts of the faults forming the Shay graben have experienced renewed movement. Apparent displacement of Quaternary gravel-covered 
pediment occurs on the south Shay graben fault (W-C, 1982a). More detailed geologic investigations such as trenching would be required to substantiate the faulting activity. Based on seismic activity near Verdure in 1993 and possible Quaternary ages of faults in both systems, the groups are considered capable tectonic faults and are potential design faults.

Fault group 7. These nontectonic faults occur along the crest of the collapsed anticline of the Paradox Valley about $14 \mathrm{mi}(23 \mathrm{~km})$ from the site. As with the Lisbon Valley faults, these features are the result of the collapse of rock units along the anticlinal crest during and following removal of subsurface evaporite bodies by solutioning. LSA reconnaissance flights over the Paradox Valley revealed numerous slump blocks along the ridges bounding the valley. Field inspection revealed that most mapped and observed faults occur along the slip surfaces of these slump blocks. Therefore, most of the numerous faults parallel to the valley trend are surface expressions of the failure planes of the landslide slump blocks. Field inspection revealed no recent movement of the blocks nor geomorphic evidence of recent offset in surficial sediments. All bedrock faults are associated with the collapse of the anticline crest. No evidence of movement on these nontectonic bedrock faults was found, although the valley-bounding faults may be experiencing slow creep and they are considered active.

Fault group 9. The Big Gypsum Valley faults exhibit the same general characteristics as the Paradox Valley faults. Most of the mapped faults are the surface expression of slump blocks along the sides of the valley formed by the collapsed anticline. Bedrock faults are nontectonic and are the result of anticline crest collapse following removal of subsurface evaporite bodies. The 1970 earthquake epicenter $M=4.0$ occurred at the southern end of this anticline structure where it converges with the San Juan Mountain uplift. LSA reconnaissance flights and field inspection revealed no evidence of fault scarps offsetting surficial deposits; however, these nontectonic faults are considered presently active. The tectonic faults underlying Big Gypsum Valley are considered noncapable. Assuming the salt anticline collapse structures are active and using the estimates of Kirkham and Rogers (1981), a design earthquake of magnitude 5.0 is assumed to occur on the nearest major graben faults of Big Gypsum Valley at a hypocentral distance of $4.0 \mathrm{mi}(6.4 \mathrm{~km})$, resulting in a PHA of 0.23 at the site (Campbell and Bozorgnia, 1994) (Table 2.5). The northwest orientation of the anticline/fault structure is expected to be the controlling influence on the direction of ground motion and the focus is expected to be oriented on this trend rather than concentric, making this PHA estimate conservative for the site. In any event, the acceleration from this event would be less than the assumption of an FE of magnitude 6.2 at $9.3 \mathrm{mi}$ $(15 \mathrm{~km}$ ) that will result in an acceleration of $0.21 \mathrm{~g}$ (Campbell, 1981 ) or $0.23 \mathrm{~g}$ (Campbell and Bozorgnia, 1994).

Fault group 10. Faults in area 10 on Plate 2.1 appear to be related both to partial collapse of rock strata caused by salt flowage and to regional tectonic folding. The western faults are probably caused by salt-cored anticline 
formation and partial collapse. The eastern faults are bedrock faults apparently caused by structural folding during the mid-Tertiary. LSA reconnaissance revealed no evidence of scarps in surficial deposits. However, because the system appears to be an extension of the Dolores salt anticline and because of the possible activity of groups 1 and $1 \mathrm{~A}$, it is considered an active nontectonic structure. The location accuracy ( $\pm 30 \mathrm{mi}$ [48 km]) of the 1941 earthquake $\left(\mathrm{M}_{\mathrm{L}}\right.$ $3.0)$ is suspect and most likely associated with the nearby Uncompahgre Uplift. Because the tectonic capability of folded structures is unknown, the FE is discussed below.

Fault groups 8 and 11. Both these faults occur along the southwest side of the Uncompahgre Plateau. Based on their distance and rupture length either of these faults is a potential design fault for the site. The Uncompahgre uplift is a recurrently active feature that has experienced considerable uplift since the Late Pliocene. The faults along the southwest side of the plateau may be capable, but have not been proven to have experienced Quaternary movement. The most conservative approach is to consider them capable faults. None of the faults in these areas are potential design faults for the site.

\section{Age of undissected Quaternary deposits}

Based on a "GeoRef" search and examination of the latest literature (1994), there have been no studies on the age of Quaternary deposits relative to faulted valley sediments in the collapsed salt anticlines within the site region. The nearest studies of soil age have been in the Fisher Valley north of the La Sal Mountains, Utah, where dating of Fisher Creek stream deposits indicates the collapse of that portion of the anticline began 2.5 million years ago and ended about 0.25 million years ago (Colman et al., 1988). These ages are related to basin fill sediment deposition and erosion cycles rather than faulting.

The age of the unconsolidated colluvium that masks the salt collapse graben faults has not been dated beyond the designation of Pleistocene by Cater (1970), Shawe (1970), and Woodward-Clyde (W-C, 1983). The WoodwardClyde 1983 summary concludes that the collapsing process is still in progress at a very slow rate and that most studies believe the faults do not penetrate into the salt beds. The slow movement is associated with the plastic flow or creep of the salt bodies as they continue to adjust to the primary Pleistocene collapse. Because of the steepness of the confining graben walls in the Big Gypsum Valley, Lisbon Valley, and Paradox Valley, it can be concluded that valley floor fan and slope deposition is active throughout the valleys and has continued since the grabens began developing in the Miocene. Holocene (i.e., less than 10,000 years old) displacement likely has occurred within the grabens.

The age of the oldest deposits undissected by faults, and therefore the age of last fault movement, is not considered significant because these faults are not critical to the design acceleration. This determination is based on the assessment that the potential ground motion affecting the site from the salt 
collapse structures is less than the potential motion that would result from a FE of magnitude 6.2 at a radial distance of $9.3 \mathrm{mi}(15 \mathrm{~km})$.

Structures delineated during the LSA aerial reconnaissance and photogeologic studies

The area within a $65-\mathrm{km}$ radius of the site was thoroughly examined for indications of capable faulting. This area was also checked for undefined regional structures that could affect the seismic risk evaluation at the site.

Regional joint patterns are prominent on aerial photos of the site region. Joints within the Paradox Basin area are related to the regional deformation produced by folding during the Paleozoic. Joint sets show northeast and northwest orientations. Studies of regional lineaments and joint patterns $(W-C, 1982 a$; Shawe, 1970) indicate they were formed during multiple folding episode and were enhanced at the surface by Cenozoic erosion. Lineaments do not appear to be rejuvenated ancestral fractures in Precambrian rocks (W-C, 1982a). Surface enhancement has been greatest on northeast-trending joints.

The balance of lineaments and structures delineated by the interpretation of aerial photos and during LSA aerial reconnaissance correlated to mapped faults and fold structures in the compilation of Williams (1964), Haynes et al. (1972), and Kirkham and Rogers (1981).

\section{Epicentral compilation}

Two earthquake epicenters are listed in the NGDC/NOAA earthquake data file for magnitude 4.0 or Intensity I events within the $65-\mathrm{km}$ radius of the sites. The epicenters of these events are plotted on Plate 2.1. Two microseismic events with unknown magnitudes or intensity were located near Egnar, Colorado, by other sources: one in October 1971 (Arabasz et al., 1979), $M=2.3$ (estimated); and one in May 1941 (Kirkham and Rogers, 1981). Because this area is mined intensely for uranium and vanadium, it is expected that the events may be related to mining. Another explanation may be the relationship to salt core adjustment in the Dolores anticline. There does not appear to be a relationship to known faults in the area. NGDC/NOAA data show two 1993 events in the Verdure area that ate associated with an active system of fault group 2.

The 3.February 1970 earthquake event north of Lone Cone $32 \mathrm{mi}(51 \mathrm{~km})$ from the site may be related to the bedrock faults flanking the mountain or to deep subsurface adjustment of a magma body. The estimated magnitude is 4.0 with a focal depth of $21 \mathrm{mi}(33 \mathrm{~km}$ ) (Kirkham and Rogers, 1981). No Quaternary fault movement has been observed on the Lone Cone faults. The faults are not capable and are not critical to design acceleration for the site. 


\section{Design seismic acceleration}

On the basis of this seismotectonic analysis of faults within a $65-\mathrm{km}$ radius of the site, the FE should be adopted as the design earthquake. This earthquake is assumed to occur at a radial distance of $9.3 \mathrm{mi}(15 \mathrm{~km})$ from the sites. A design earthquake of magnitude $\left(M_{L}\right) 6.2$ occurring at this distance would produce a free-field, nonamplified, peak horizontal ground acceleration at the site of $0.21 \mathrm{~g}$ (Campbell, 1981) and updated to $0.23 \mathrm{~g}$ based on Campbell and Bozorgnia (1994).

\section{Potential for on-site fault rupture}

As discussed above, there are no indications of any capable faults in the immediate site area. No faults pass through the Burro Canyon disposal site. The closest mapped fault lies about $1.1 \mathrm{mi}(1.8 \mathrm{~km})$ from the site. This feature was examined carefully during the site investigations and showed no indication of Quaternary movement.

\section{Potential liquefaction hazard}

The unsaturated bedrock foundation of the site is not susceptible to liquefaction.

\section{Reservoir-induced seismicity}

A review of the previous literature by Meade (1982) indicates that the phenomenon occurs only where faults are associated with deep reservoirs with large storage capacity.

There are no large reservoirs with sufficient depth or volume to induce seismic activity in the region of the Burro Canyon disposal site at the present time. The largest reservoir is the McPhee Reservoir on the Dolores River near Dolores, Colorado, approximately $36 \mathrm{mi}(58 \mathrm{~km})$ from the site. There are no known active faults associated with this reservoir or within the alignment of the Dolores River. The reservoir does not meet the other minimum criteria of depth in excess of $302 \mathrm{ft}(92.1 \mathrm{~m})$ and volume in excess of 1 million acre $\mathrm{ft}$ $\left(1 \times 10^{9} \mathrm{~m}^{3}\right)(\mathrm{W}-\mathrm{C}, 1979)$. The limited storage capacity and drainage area of other impoundments in the region preclude the likelihood of their triggering seismic events. Therefore, there is no probability of reservoir-induced seismicity in the area. 


\subsection{GEOLOGIC SUITABILITY}

This section discusses the geological site conditions that are considered potential deficiencies in meeting requirements for long-term stability.

\subsection{FOUNDATION MATERIALS ·}

The potential problems with the bedrock are primarily related to transient water drainage of the cell and the potential for perching and migration (see Attachment 3). Because of the volume of transient drainage it is recommended that the thin cap rock sandstone units be excavated and dissected on the downslope (south) edge of the cell to prevent possible seepage migration off the site through these strata. The mostly silica mineralogy of the bedrock is considered nonreactive to tailings leachate. The carbonaceous (organic) shales in the lower Dakota Sandstone are expected to aid in attenuating chemical concentration levels.

\subsection{SURFACE DRAINAGE AND EROSION}

The cell cover may be drained onto the apron, which divert flow over the crest of the rimrock or concentrate it between the cell and the sandstone ridge at the southeast corner of the site. Since the perimeter flow will concentrate naturally on the cell apron at certain locations, the apron surface should be designed to collect runoff and armored to protect against erosion of the soft bedrock areas.

The apron on the south and southeast edge of the cell will be underlain by the soft weathered, black carbonaceous shale that is especially susceptible to gullying by concentrated flows. Erosion protection for concentrated flows should be extended to the lower slope of the mesa.

It is especially important to maintain a 100-ft $(30-\mathrm{m})$ setback from the edge or scarp of the mesa rim as a protection against scarp retreat, to ensure the longterm stability of the disposal site. This zone should be protected against any excavations that might substantially fracture the edge or make it more vulnerable to erosion. If regrading the buffer zone for drainage is necessary, the grade should be raised by filling so the resistant edges of the mesa are left intact as much as possible.

\section{$5.3 \quad$ SEISMICITY}

The design earthquake is based on an FE of magnitude 6.2 and has resultant PHA of $0.21 \mathrm{~g}$ at the site. There are no concerns about instability from design seismic parameters or from regional nontectonic sources.

\subsection{UNEXPLOITED NATURAL RESOURCES}

There is potential for development of uranium and vanadium ore below the site. The depth of the ore, at $900 \mathrm{ft}(300 \mathrm{~m})$, and the thin zones in which it occurs make it very unlikely that such activity would affect the integrity of the site. Calculations for the potential effects of mining below the site, based on nearby 
conditions in the Burro Canyon Mine indicate that no detrimental effects to the long-term stability of the cell (see Calculation No. SRK-90-03-03-00) in the appendix to this attachment. The potential for subsidence related to hydrocarbon production near the site would be of similarly negligible impact due to the integrity of the bedrock formations that overly potential production zones. These zones would be expected to be within the Pennsylvanian and Mississippian strata (or older rocks), which are not exposed on the surface within the area of the Disappointment syncline structure.

Shawe et al. (1968) reported that numerous oil test borings have penetrated to the Precambrian basement rocks within the Slick Rock Mining District (which includes the north half of Disappointment Valley), and the focus of most of the investigations has been the upper unit of the Paradox Member of the Hermosa Formation of Pennsylvanian age. This unit is the most important gas- and oilproducing interval within the Paradox Basin. Shawe et al. (1968) show the unit is $500 \mathrm{ft}(150 \mathrm{~m})$ thick at the Burro Canyon site.

An exploration well on the axis of the Disappointment syncline just southwest of the disposal site was drilled in 1979 (Figures 2.7 and 2.8). This dry well was drilled to $9402 \mathrm{ft}(2866 \mathrm{~m})$ into the upper unit of the Paradox Member and subsequently was plugged. The 10-year lease for that company expired in 1983. Currently, a gas and oil lease covers the disposal site area in section 28 and portions of adjoining section 21 to the north. The adjoining sections (20, 22,19 , and 27) also contain gas and oil leases within the disposal site area. The most recent activity was a test hole drilled in 1990 near a previous test hole $4 \mathrm{mi}(6 \mathrm{~km})$ east, on the flanks of the Disappointment syncline.

Shawe (1968) report that no oil has been produced in this area, but shows of gas (including carbon dioxide from the Paradox Member) have been reported 5 $\mathrm{mi}(8 \mathrm{~km})$ north and $11 \mathrm{mi}(18 \mathrm{~km})$ southwest of the site in the Dolores anticline. Some gas continues to be produced from Andy's Mesa east of Gypsum .Valley.

Since no faults in the immediate vicinity of the site would be the focus of petroleum entrapment or of differential displacement, any subsidence resulting from oil or gas production would be fairly uniformly distributed over the surrounding area. Another factor that would mitigate the effects of subsidence related to any nearby production is the relatively small area of the disposal site compared to the area of a production zone where minimal well spacing for any size reservoir typically would not result in the placement of more than one well. In addition, the cell cover thickness is designed to provide protection against cover cracking.

All disturbances from exploration or from development of natural resources are expected to be insignificant compared to the design seismic event of $0.23 \mathrm{~g}$. Direct intrusion of the cell by such resource activity will be protected by the Secretary of the Interior through withdrawal of the land. 


\section{$5.5 \quad$ VOLCANIC HAZARDS}

Volcanic and igneous activity do not threaten the site area. No Quaternary volcanic rocks occur in the area. The closest center of Quaternary volcanic activity is near Cameron, Arizona, over $100 \mathrm{mi}(200 \mathrm{~km})$ from the site. The youngest igneous intrusive rocks are Early Miocene in age and occur in the Abajo and La Sal Mountains in eastern Utah.

\subsection{POTENTIAL FUTURE IMPACT OF SALT-COLLAPSE PHENOMENA}

The site is in the salt anticlines region of southwestern Colorado. The salt anticlines consist of a series of large anticlinal folds having intrusive cores of salt and gypsum derived from the Paradox Member of the Pennsylvanian Hermosa Formation (Shawe et al., 1968; Cater, 1970). The salt-cored anticlines and intervening synclines are northwest-trending folds lying on the southwestern flank of the Uncompahgre Uplift, extending from southwestern Colorado into Utah (Figure 2.4). Collapse of the crests of the anticlines due to salt core flowage has created nontectonic faults and slump block zones trending parallel to the folds.

Shawe (1968) shows the Gypsum Valley collapse anticline has $10,000 \mathrm{ft}$ $(3000 \mathrm{~m})$ of salt core and the uncollapsed Dolores anticline has a $4000-\mathrm{ft}$ $(1200-\mathrm{m})$-thick salt core. The Disappointment syncline has only $1000 \mathrm{ft}$ $(300 \mathrm{~m})$ of salt. Most of the underlying salt layer apparently has been squeezed out from beneath the syncline, and the site area is not susceptible to the development of salt-collapse features.

Normal faults associated with the Dolores/Lisbon Valley anticline lie within $2.5 \mathrm{mi}(4 \mathrm{~km})$, southwest of the site (Plate 2.1 and Figure 2.5). The displacements on faults nearest the site are generally less than $100 \mathrm{ft}(30 \mathrm{~m})$. Cater (1970) states that these faults may have formed in response to either collapse of the salt core of the Dolores/Lisbon Valley anticline or to tensional stresses developed during folding. Several northeast-trending faults on the northeast end of the Disappointment Valley syncline lie within $1 \mathrm{mi}(1.6 \mathrm{~km})$, the north of the site. The Gypsum Valley anticline collapse faults are within 2 miles $(3.2 \mathrm{~km})$, northeast of the site.

No fault has been recognized in the immediate site location, and none of the faults in the surrounding area have been shown to be active. Therefore, it is unlikely that any faulting related to the salt core collapse or dissolution will occur at the site during the design life of the proposed facilities. 


\subsection{REFERENCES}

Algermissen, S. T., and D. M. Perkins, 1976. A Probabilistic Estimate of Maximum Acceleration in Rock in the Contiguous United States, U.S. Geological Survey, Open-File Report 76-416.

Algermissen et al. (S. T. Algermissen, D. M. Perkins, P. C. Thenhaus, S. L. Hanson, and B. L. Bender), 1982. Probabilistic Estimates of Maximum Acceleration and Velocity in Rock in the Contiguous United States, U.S. Geological Survey, Open-File Report 82-1033.

Arabasz et al. (W. J. Arabasz, J. C. Pechmann, and E. D. Brown), 1992. "Observational Seismology and the Evaluation of Earthquake Hazards and Risk in the Wasatch Front Area, Utah," in Assessment of Regional Earthquake Hazards and Risk Along the Wasatch Front, Utah, P. L. Gori and W. W. Hays, eds., U.S. Geological Survey Professional Paper 1500-D, pp. D-1 to D-36.

Arabasz et al. (W. J. Arabasz, R. B. Smith, and W. D. Richins), 1979. Earthquake Studies in Utah, 1850 to 1978, Special Publication 5527, University of Utah Seismograph Stations, Department of Geology and Geophysics, University of Utah, Salt Lake City, Utah.

ATC (Applied Technology Council; associated with the Structural Engineers Association of California), 1978. Tentative Provisions for the Development of Seismic Regulations for Buildings, ATC Publication ATC-3-06, also National Bureau of Standards Publication 510, National Science Foundation Publication 78-8.

Baker, R. G., 1983.. "Holocene Vegetational History of the Western United States," in Late-Quaternary Environments of the United States, Vol 2; The Holocene, H. E. Wright, Jr., ed., University of Minnesota Press, Minneapolis, Minnesota, pp. 109-128.

Bonilla et al. (M. G. Bonilla, R. K. Mark, and J. J. Lienkaemper), 1984. "Statistical Relations Among Earthquake Magnitude, Surface Rupture Length, and Surface Fault Displacement," in Bulletin of the Seismological Society of America, Vol. 74, No. 6, pp. 2379-2411.

Boore, D. M., and W. B. Joyner, 1994. "Prediction of Ground Motion in North America," in Proceedings of the Seminar on New Developments in Earthquake Ground Motion Estimation and Implications for Engineering Design Practice, Applied Technology Council, Redwood City, California, pp. 6-1 to 6-41.

Boore et al. (D. M. Boore, W. B. Joyner, and T. E. Fumal), 1994. Estimation of Response Spectra and Peak Accelerations From Western North American Earthquakes: An Interim Report, Part 2, U.S. Geological Survey, Open File Report 94-127. 
Bradley, R. G., and R. S. Barry, 1976. "Historical Climatology," in Ecological Impacts of Snowpack Augmentation in the San Juan Mountains, Colorado, Final Report, H. W. Steinhoff and J. D. Ives, eds., San Juan Ecology Project, Colorado State University, Fort Collins, Colorado, pp. 43-67.

Bradley, R. S., 1976. Precipitation History of the Rocky Mountain States, Westview Press, Boulder, Colorado.

Campbell, K. W., 1991. "Analysis of Ground-Shaking Hazard and Risk for Lifeline Systems," in Lifeline Earthquake Engineering, Proceedings of the Third U.S. Conference, Technical Council on Lifeline Earthquake Engineering, American Society of Civil Engineers, Monograph No. 4, August 1991, Los Angeles, California.

Campbell, K. W., 1987. "Predicting Strong Ground Motion in Utah, in Assessment of Regional Earthquake Hazards and Risk Along the Wasatch Front, Utah, P. L. Gori and W. W. Hays, eds., U.S. Geological Survey, Open File Report 87-585, Vol. II.

Campbell, K. W., 1984. "Near-Source Attenuation of Strong Ground Motion for Moderate to Large Earthquakes - An Update and Suggested Application to the Wasatch Fault Zone of North-Central Utah," in Proceedings of Conference XXVI, A Workshop on Evaluation of Regional and Urban Earthquake Hazards and Risk in Utah, W. Hays and P. Gori, eds., U.S. Geological Survey, Open File Report 84-763.

Campbell, K. W., 1981. "Near-Source Attenuation of Peak Horizontal Acceleration," in Bulletin of the Seismological Society of America, Vol. 71, pp. 2039-2070.

Campbell, K. W., and Y. Bozorgnia, 1994. "Near-Source Attenuation of Peak Horizontal Acceleration From Worldwide Accelerograms Recorded From 1957 to 1993," in Proceedings of the Fifth U.S. National Conference on Earthquake Engineering, Earthquake Engineering Research Institute, Chicago, Illinois, Vol. III, pp. 283-292.

Cater, F. W., Jr., 1970. Geology of the Salt Anticline Region in Southwestern Colorado, With a Section on Stratigraphy, by F. C. Cater and L. C. Craig, U.S. Geological Survey, Professional Paper 637.

Cater, F. W., Jr., 1966. Age of the Uncompahgre Uplift and Unaweep Canyon, West-Central Colorado, U.S. Geological Survey, Professional Paper 550-C, pp. C86-C92.

Cater F. W., Jr., 1955. "Geology of the Horse Range Mesa Quadrangle, Colorado," U.S. Geological Survey, Geologic Quadrangle Map GQ 64.

Chenoweth, W. L., 1984. "Paradox Valley, Colorado, A Collapsed Salt Anticline," unpublished report, Sergent, Hauskins \& Beckwith, Phoenix, Arizona. 
Chenoweth, W. L., 1981. "The Uranium-Vanadium Deposits of the Uravan Mineral Belt and Adjacent Areas, Colorado and Utah," in Western Slope Colorado, New Mexico Geological Society Guidebook, 32nd Field Conference, New Mexico Geological Society, pp. 165-170.

Coffman et al. (J. L. Coffman, C. A. Von Hake, and C. W. Stover), 1982. Earthquake History of the United States, U.S. Department of Commerce, National Oceanic and Atmospheric Administration, Publication 41-1.

Cole, R. D., and J. L. Sexton, 1981. "Pleistocene Surficial Deposits of the Grand Mesa Area, Colorado," in Western Slope Colorado, R. C. Epis and J. F. Callender, eds., New Mexico Geological Society Guidebook, 32nd Field Conference, pp. 121-126.

Colman et al. (S. M. Colman, A. F. Choquette, and F. Hawkins), 1988. "Physical, Soil and Paleomagnetic Stratigraphy of the Upper Cenozoic Sediments in Fisher Valley, Southwestern Utah," prepared in cooperation with the U.S. Department of Energy, Denver, Colorado, U.S. Geological Survey, Bulletin 1686.

Curry, D. R., 1976. "Late Quaternary Geomorphic History of Pint Size Shelter," in Pint Size Shelter, L. W. Lindsay and C. K. Lund, eds., Antiquities Section Selected Paper No. 10, Division of State History, State of Utah, Salt Lake City, Utah.

Damon et al. (P. E. Damon, M. Shafiqullah, and R. B. Scarborough), 1978. "Revised Chronology for Critical Stages in the Evolution of the Lower Colorado River," in Geological Society of America, Abstracts With Programs, Vol. 10, p. 101.

dePolo, C. M., 1994. "The Maximum Background Earthquake for the Basin and Range Province, Western North America," in Bulletin of the Seismological Society of America, Vol. 84, No. 2, pp. 466-472.

DOE (U.S. Department of Energy), 1989. Technical Approach Document, prepared by the U.S. Department of Energy, UMTRA Project Office, Albuquerque Operations Office, Albuquerque, New Mexico.

DOE (U.S. Department of Energy), 1985. Memorandum prepared by R. E. Weeks, SHB, for the Technical Assistance Contractor, UPDCC File Location No. 0.19.1.3, Albuquerque, New Mexico, 4 September 1985.

DuBois et al. (S. M. DuḂois, A. W. Smith, N. K. Nye, and T. A. Nowak, Jr.), 1982. Arizona Earthquakes, 1776-1980, Arizona Bureau of Geology and Mineral Technology, Bulletin No. 193, Scale 1:1,000,000.

Eberhart-Phillips et al. (D. Eberhart-Phillips, R. M. Richardson, M. L. Sbar, and R. B. Herrmann), 1981. "Analysis of the 4 February 1976 Chino Valley, Arizona, Earthquake," in Bulletin of the Seismological Society of America, Vol. 71, No. 3, pp. 787-801. 
Elston, D. P., and E. R. Landis, 1960. Pre-Cutler Unconformities and Early Growth of the Paradox Valley and Gypsum Valley Salt Anticlines, Colorado, U.S. Geological Survey, Professional Paper 400-B, pp. 261-265.

Ely et al. (R. W. Ely, I. G. Wong, and Ping-Sheng Chang), 1986. "Neotectonics of the Uncompahgre Uplift, Eastern Utah and Western Colorado, " in Contributions to Colorado Seismicity and Tectonics, W. P. Rogers, ed., Colorado Geological Survey, Denver, Colorado, pp. 75-92.

Frankel et al. (A. Frankel, P. Thenhaus, D. Perkins, and E. B. Leyendecker), 1994. "Ground Motion Mapping-Past, Present and Future," in Proceedings of the Seminar on New Developments in Earthquake Ground Motion Estimation and Implications for Engineering Design Practice, Applied Technology Council, Redwood City, California, pp. 7-1 to 7-40.

Fritts, H. C., 1971. "Dendroclimatology and Dendroecology," in Quaternary Research, Vol. 1, No. 4, pp. 419-449.

Gable, D., and T. Hatton, 1983. Vertical Crustal Movements in the Conterminous United States Over the Last 10 Million Years, U.S. Geological Survey, Open-File Report 80-180.

Giardina, S., Jr., 1977. "A Regional Seismic Evaluation of Flagstaff, Arizona," in Bulletin of the Association of Engineering Geologists, Vol. 14, No. 2, pp. 89-103.

Gile et al. (L. H. Gile, T. W. Hawley, and R. B. Grossman), 1981. Soils and Geomorphology in the Basin and Range Area of Southern New Mexico Guidebook to the Desert Project, New Mexico Bureau of Mines and Mineral Resources, Memoir 39, Socorro, New Mexico.

Glass, C. E., and D. B. Slemmons, 1978. State-of-the-Art for Assessing Earthquake Hazards in the United States, Report II: Imagery in Earthquake Analysis, U.S. Army Engineer Waterways Experiment Station, Miscellaneous Paper S-73-1, Vicksburg, Mississippi.

Gutenberg, B., and C. F. Richter; 1956. "Earthquake Magnitude, Intensity, Energy, and Acceleration," in Bulletin of the Seismological Society of America, Vol. 46, No. 1, pp. 105-145.

Haman, J. F., 1983. Comment on "Use of Packrat Middens to Determine Rates of Cliff Retreat in the Eastern Grand Canyon, Arizona," in Geology, Vol. 11, pp. 315-316.

Haynes et al. (D. D. Haynes, J. D. Vogel, and D. G. Wyant), 1972. "Geology, Structure, and Uranium Deposits of the Cortez Quadrangle, Colorado and Utah," U.S. Geological Survey, Miscellaneous Investigations Series Map 1-629.

Herrmann et al. (R. B. Herrmann, J. W. Dewey, and S. K. Park), 1980. "The Dulce, New Mexico Earthquake of January 23, 1966," in Bulletin of the Seismological Society of America, Volume 70, No. 6, pp. 2171-2184. 
Hite, R. J., 1975. "An Unusual Northeast-Trending Fracture Zone and Its Relation to Basement Wrench Faulting in Northern Paradox Basin, Utah and Colorado," in Canyonlands Country, J. E. Fassett and S. A. Wengerd, eds., Four Corners Geological Society Guidebook, 18th Field Conference, pp. 217-233.

Hunt, C. B., 1974. Natural Regions of the United States and Canada, W. H. Freeman and Company, San Francisco, California.

Hunt, C. B., 1969.. Geologic History of the Colorado Plateau, in U.S. Geological Survey, Professional Paper 669-C, pp. 59-130.

Hunt, C. B., 1967. Physiography of the United States, W. H. Freeman and Company, San Francisco, California.

Hunt, C. B., 1958. Structural and Igneous Geology of the La Sal Mountains, Utah, U.S. Geological Survey, Professional Paper 294-I.

Hunt, C. B., 1956. Cenozoic Geology of the Colorado Plateau, U.S. Geological Survey, Professional Paper 279.

Johnson, R. G., 1982. "Bruhnes-Matuyama Magnetic Reversal Dated at 790,000 yr. B. P. by Marine-Astronomical Correlation," in Quaternary Research, Vol. 17, No. 2, pp. 135-147.

Johnson et al. (J. A. Johnson, T. F. Blake, B. L. Schmidt, and J. E. Slosson), 1992. "Short Course on Earthquake Site Analysis and Critical Facility Siting," Association of Engineering Geologists, Long Beach, California, Annual Meeting.

Joyner, W. B., and D. M. Boore, 1988. "Measurement, Characterization, and Prediction of Strong Ground Motion," in Earthquake Engineering and Soil Dynamics /I-Recent Advances in Ground-Motion Evaluation, J. L. Von Thun, ed., American Society of Civil Engineers, Geotechnical Special Publication No. 20, New York, New York, pp. 43-102.

Keaton, J., 1994a. UMTRA White Paper: Review of Ground Motion Attenuation Relationships, SHB-AGRA Earth and Environmental, Salt Lake City, Utah, 25 August 1994.

Keaton, J., 1994b, UMTRA White Paper: Review of the Background Earthquake, SHB AGRA Earth and Environmental, Salt Lake City, Utah, UPDCC File Location No. 0.19.1.3, Albuquerque, New Mexico, 26 August 1994.

Keller et al. (G.'R. Keller, L. W. Braile, and P. Morgan), 1979. "Crustal Structure, Geophysical Models and Contemporary Tectonism of the Colorado Plateau," in Plateau Uplift: Mode and Mechanism, T. R. McGetchin and R. B. Merrill, eds., Tectonophysics, Vol. 61, pp. 131-147.

Kirkham, R. M., and W. P. Rogers, 1981. Earthquake Potential in Colorado, a Preliminary Evaluation, Colorado Geological Survey, Bulletin No. 43. 
Knox, J. C., 1983. "Responses of Rivers to Holocene Climates," in Late Quaternary Environments of the United States, Vol. 2. The Holocene, H. E. Wright, Jr., ed., University of Minnesota Press, Minneapolis, Minnesota, pp. 26-41.

Krinitzsky, E. L., and F. K. Chang, 1975. State-of-the-Art for Assessing Earthquake Hazards in the United Sates, Report 4: Earthquake Intensity and the Selection of Ground Motions for Seismic Design, U.S. Army Engineer Waterways Experiment Station, Miscellaneous Paper S-74-1, Vicksburg, Mississippi.

Krivanek, C. M., 1981. "New Fields and Exploration Drilling, Paradox Basin, Utah and Colorado," in Geology of the Paradox Basin, D. L. Wiegand, ed., Rocky Mountain Association of Geologists, pp. 77-81.

Larson et al. (E. E. Larson, M. Ozima, And W. C. Bradley), 1975. "Late Cenozoic Basic Volcanism in Northwestern Colorado and its Implications Concerning Tectonism and the Origin of the Colorado River System," in Cenozoic History of the Southern Rocky Mountains, B. F. Curtis, ed., Geological Society of America, Memoir 144, pp. 155-178.

Liu, S. C., and N. J. DeCapua, 1975. "Microzonation of Rocky Mountain States," in Proceedings of the U.S. National Conference on Earthquake Engineering, Earthquake Engineering Research Institute, Ann Arbor, Michigan, pp. 128-135.

Lohman, S. W., 1981. "Ancient Drainage Changes in and South of Unaweep Canyon, Southwestern Colorado," in Western Slope Colorado, R. C. Epis and J. F. Callender, eds., New Mexico Geological Society Guidebook, 32nd Field Conference, pp. 137-143.

Lohman, S. W., 1965. Geology and Artesian Water Supply, Grand Junction Area, Colorado, U.S. Geological Survey, Professional Paper 451.

Luchitta, I., 1972. "Early History of the Colorado River in the Basin and Range Province," in Geological Society of America Bulletin, Vol. 83, pp. 1933-1948.

Markgraf, V., and L. Scott, 1981. "Lower Timberline in Central Colorado During the Past 15,000 Years," in Geology, Vol. '9, pp. 231-234.

McKee, E. D., and E. H. McKee, 1972. "Pliocene Uplift of the Grand Canyon Region Time of Drainage Adjustment," in Geological Society of America Bulletin, Vol. 83, pp. 1923-1932.

Meade, R. B., 1982. "State-of-the-Art for Reducing Earthquake Hazards in the United States: Report 19: The Evidence for Reservoir-Induced Macroearthquakes," U.S. Army Engineer Waterways Experiment Station, Miscellaneous Paper S-741, Vicksburg, Mississippi.

Nelson et al. (J. D. Nelson, R. L. Volpe, R. E. Wardwell, S. A. Schumm, and W. P. Staub), 1983. Design Considerations for Long-Term Stabilization of Uranium Mill Tailings Impoundments, NUREG/CR-339, ORNL-5979, U.S. Nuclear Regulatory Commission, Washington, D.C. 
NGDC/NOAA (National Geophysical Data Center/National Oceanic and Atmospheric Administration), 1994. "Seismicity Within $150 \mathrm{Km}$ of $38.08 \mathrm{~N}, 108.87 \mathrm{~W}$," epicenter map and table of earthquake data, Boulder, Colorado.

NGDC/NOAA (National Geophysical Data Center/National Oceanic and Atmospheric Administration), 1989. "Dry Flats site, Colorado: Epicentral Compilation for Magnitude $M=4$ and I = I-IV," Boulder, Colorado.

NOAA (National Oceanic and Atmospheric Administration), 1975. "Climate of Colorado," in Climatography of the United States, Environmental Data Service, NOAA, National Climatic Center, Asheville, North Carolina.

Nuttli, O. W., and R. B. Herrmann, 1982, "Earthquake Magnitude Scales," in Journal of the Geotechnical Engineering Division, ASCE, No. GT5, Proceedings Paper 17048, pp. 783-786.

Ohlen, H. R., and L. B. Mclntyre, 1965. "Stratigraphy and Tectonic Features of Paradox Basin, Four Corners Area," in Bulletin of the American Association of Petroleum Geologists, Vol. 49, No. 11, pp. 2020-2040.

Richmond, G. M., 1962. Quaternary Stratigraphy of the La Sal Mountains, Utah, U.S. Geological Survey, Professional Paper 324.

Schumm, S. A., and R. J. Chorley, 1983. Geomorphic Controls on the Management of Nuclear Waste, NUREG/CR-3276RW, U.S. Nuclear Regulatory Commission, Washington, D.C.

Schumm, S. A., and R. J. Chorley, 1966. "Talus Weathering and Scarp Recession in the Colorado Plateau," in Zeitschrift fur Geomorphologie, Vol. 10, No. 1, pp. 11-36.

Shawe, D. R., 1970. Structure of the Slick Rock District and Vicinity, San Miguel and Dolores Counties, Colorado, U.S. Geological Survey, Professional Paper 576-C, Washington, D.C.

Shawe, D. R., 1968. Petrography of Sedimentary Rocks in the Slick Rock District, San Miguel and Dolores Counties, Colorado, U.S. Geological Survey, Professional Paper 576-B, Washington, D.C.

Shawe et al. (D. R. Shawe, G. C. Simmons, and N. L. Archbold), 1968. Stratigraphy of Slick Rock District and Vicinity, San Miguel and Dolores Counties, Colorado, U.S. Geological Survey, Professional Paper 576-A.

Shawe et al. (D. R. Shawe, N. L. Archbold, and G. C. Simmons), 1959. "Geology and Uranium-Vanadium Deposits of the Slick Rock District, San Miguel and Dolores Counties, Colorado," in Economic Geology, Vol. 54, pp. 395-415.

Sinnock, S. B., 1981a. "Glacial Moraines, Terraces and Pediments of Grand Valley, Western Colorado," in Western Slope Colorado, R. C. Epis and J. F. Callender, eds., New Mexico Geological Society Guidebook, 32nd Field Conference, pp. 113-123. 
Sinnock, S. B., 1981b. "Pleistocene Drainage Changes in Uncompahgre Plateau - Grand Valley Region of Western Colorado Including Formation and Abandonment of Unaweep Canyon: A Hypothesis," in Western Slope Colorado, R. C. Epis and J. F. Callender, eds., New Mexico Geological Society Guidebook, 32nd Field Conference, pp. 127-136.

Sinnock, S. B., 1978. "Geomorphology of the Uncompahgre Plateau and Grand Valley, Western Colorado, U.S.A.," unpublished Ph.D. thesis, Purdue University, West Lafayette, Indiana.

Smith, R. B., 1978. "Seismicity, Crustal Structure and Intraplate Tectonics of the Interior of the Western Cordillera," in Cenozoic Tectonics and Regional Geophysics of the Western Cordillera, R. B. Smith and G. P. Eaton, eds., Geological Society of America, Memoir 152, pp. 111-144.

Smith, R. B., and M. L. Sbar, 1974. "Contemporary Tectonics and Seismicity of the Western U.S. With Emphasis on the Intermountain Seismic Belt," in Geological Society of America Bulletin, Vol. 85, pp. 1205-1218.

Stockton, C. W., and G. C. Jacoby, 1976. Long-Term Surface-Water Supply and Streamflow Treads in the Upper Colorado River Basin, Based on Tree-Ring Analyses, Los Angeles Institute for Geophysics and Planetary Physics, Lake Powell Research Project, Bulletin 18, University of California, Los Angeles, California.

Stokes, W. L., and D. A. Phoenix, 1948. "Geology of the Egnar-Gypsum Valley Area, San Miguel and Montrose Counties, Colorado," U.S. Geological Survey, Oil and Gas Investigations, Preliminary Map 93.

Sullivan, J. T., and R. A. Martin, Jr., 1981. "Seismic Hazards Study for Ridgeway Dam Site, Colorado," in Colorado Tectonics, Seismicity and Earthquake Hazards, proceedings and field trip guide, symposium, Denver, Colorado.

Sullivan et al. (J. T. Sullivan, C. A. Meeder, R. A. Martin, Jr., and M. W. West), 1980. Seismic Hazard Evaluation - Ridgeway Dam and Reservoir Site - Dallas Creek Project, Colorado, unpublished report, U.S. Water and Power Resources Service, Seismotectonic Section, Denver, Colorado.

Thompson, G. A. and M. L. Zoback, 1979. "Regional Geophysics of the Colorado Plateau," in Tectonophysics, Vol. 61, pp. 149-181.

Tweto, O., 1980. "Summary of Laramide Orogeny in Colorado," in Colorado Geology, H. C. Kent and K. W. Porter, eds., Rocky Mountain Association of Geologists, 1980 symposium, Denver, Colorado, pp. 129-134.

Tweto, O., 1979. "Geologic Map of Colorado," U.S. Geological Survey, compiled by 0 . Tweto in cooperation with Geological Survey of Colorado, Scale 1:500,000. 
Von Hake, C., 1984. National Geophysical Data Center, National Oceanic and Atmospheric Administration, Boulder, Colorado, personal communication to P. Smith, Sergent, Hauskins \& Beckwith, Consulting Geotechnical Engineers, Phoenix, Arizona.

W-C (Woodward-Clyde Consultants), 1983. "Overview of the Regional Geology of the Paradox Basin Study Area," Technical Report ONW1-92, prepared for Battelle Memorial Institute, Office of Nuclear Waste Isolation.

W-C (Woodward-Clyde Consultants), 1982a. "Geologic Characterization Report for the Paradox Basin Study Region, Utah Study Areas," Technical Report ONWI-290, prepared for Battelle Memorial Institute, Office of Nuclear Waste Isolation.

W-C (Woodward-Clyde Consultants), 1982b. Report for Task $7 \mathrm{~b}$, area vs. magnitude relationship; letter to R. Chitwood of WPPSS, May 27, 1982.

W-C (Woodward-Clyde Consultants), 1979. "Study of Reservoir Induced Seismicity," U.S. Geological Survey, Open File Report 80-109.

Wiegand, D. L., 1981. Geology of the Paradox Basin, D. L. Wiegand ed., Rocky Mountain Association of Geologists, Denver, Colorado.

Williams, P. L., 1964. "Geology, Structure and Uranium Deposits of the Moab $1^{\circ} \times 2^{\circ}$ Quadrangle, Colorado and Utah," U.S. Geological Survey, Miscellaneous Geological Investigations, Map 1-360, Scale 1:250,00.

Witkind, I. J., 1964. "Age of the Grabens in Southeastern Utah," in Geological Society of America Bulletin, Vol. 75, pp. 99-106.

Wong, 1. G., 1984. Seismicity of the Paradox Basin and the Colorado Plateau Interior, Technical Report prepared by Woodward-Clyde Consultants, Walnut Creek, California, for Office of Nuclear Waste Isolation, Battelle Memorial Institute, Columbus, Ohio.

Wong et al. (I. G. Wong, J. R. Humphrey, and W. J. Silva), 1987. "Microearthquake Studies in the Vicinity of the Cane Creek Potash Mine, Paradox Basin, Utah," Technical Report BMI/ONWI-656, prepared by Woodward-Clyde Consultants for Battelle Memorial Institute, Columbus, Ohio.

Yeend, W. E., 1969. Quaternary Geology of the Grand and Battlement Mesas Area, Colorado, U.S. Geological Survey, Professional Paper 617.

Zoback, M. L., and M. D. Zoback, 1980. "State of Stress in the Continuous United States," in Journal of Geophysical Research, Vol. 85, pp. 6113-6156.

\section{CODE OF FEDERAL REGULATIONS}

10 CFR Part 100, Seismic and Geologic Siting Criteria for Nuclear Power Plants, U.S. Nuclear Regulatory Commission. 
REMEDIAL ACTION PLAN, SLICK ROCK, COLORADO

40 CFR Part 192, Health and Environmental Protection Standards for Uranium and Thorium Mill Tailings, U.S. Environmental Protection Agency. 
APPENDIX

EVALUATION OF SUBSIDENCE POTENTIAL (BURRO CANYON) 


\section{JE LACOBS ENGINEERING GROUP INC. ·}

\section{CALCULATION COVER SHEET}

GEOTECH.

CALC NO.. SRKO4-90-03-03-00 DISCIPLINE ENGINEERING NO. OF SHEETS 17

\section{PROJECT:}

UMTRA

\section{SITE:}

SLICK ROCK

\section{FEATURE:}

EVALUATION OF SUBSIDENCE POTENTIAL

(BURRO CANYON)

\section{SOURCES OF DATA:}

IMETCO MINERALS CORP. MINE MAP

U.S. Geological Lurvey Paper 576-A, "Atuatigraphy, Hich

Roch District and Vicinity, Colo.

Slick Roch ty eology Repott (Buwo Canyon), in preparation.

\section{SOURCES OF FORMULAE \& REFERENCES:}

NATIONAL COAL BOARD, SUBSIDENCE ENGINEEBS HANDBOOK, Mining

Department, London, Mational Coal Boand [Great Britain], 1975

Lee \& Shen "Noizontal Movements Rebated to Lubsidence", ASCE goumal of '21 eatech. Eng., 1969; p. 139-163.

Leonarde 4 Marain, "Flexitititity of Clay and Cuacking of Eath Dans, ASCE Poumal of Yestech. Eng., 1963, P. 47-96.

Abel+ Lee," Lithologic Cotsole on Dubaidence," AIME Tuansactions vel.274, p. 2028-2033,1977.

preliminary calc. $\square$. final calc. $\square$ supersedes calc. no.

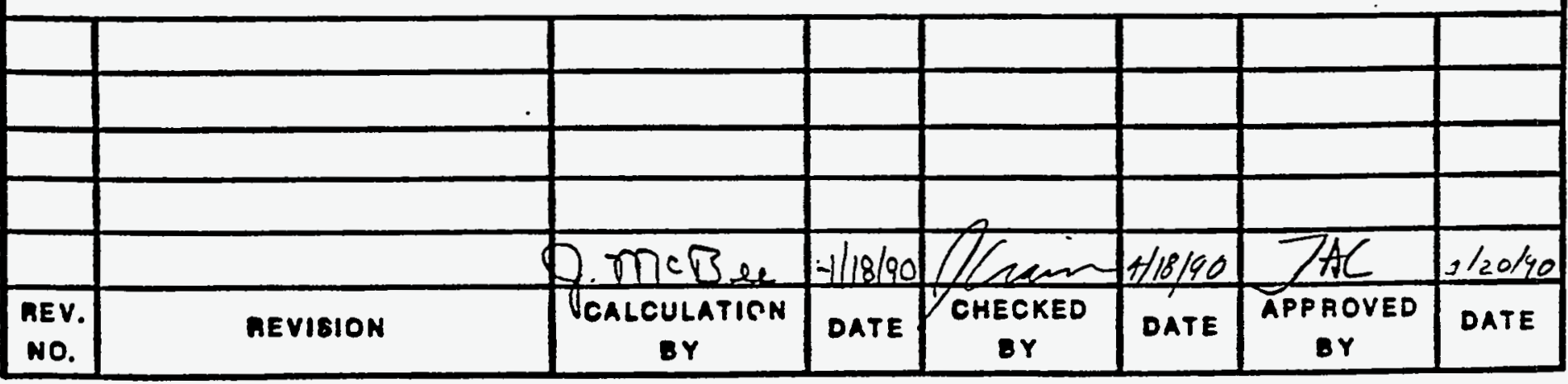


=POE:EM : ÐTATEMENT:

Eve:uate the po:ential tar sucsicience cue =c mining jeneeth the Butrc Canyan site. Assess the etiest et tinis estimeted subicience as the iniegrity ot a cisoosel cei i.

METHOD:

The met:- used to predict sutsicience is bv Abe! and Lee, (1577). Estimete the emount ct subsiden=e trom uncerground

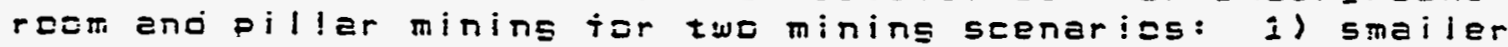
ponels with higiner extraction ratios and smelier gillars; ane 2) wiogr penels with lower extraction ratios end wider Diliars. Using the higner emount of subsionge presiztej,

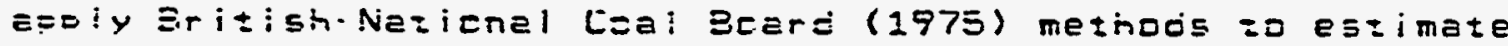
the subsigence prefile. Besed on tinisprotile, lse the ecuation by Les and Sicen (1969) to predict the patentiai erecking of the disposal cell equer

AミSUMP?: ONS:

ThE emoiricei cartalatisns by Adei ans Lee (i977) and the Netisnal Coel Baard (1975) ceveioped mestiy trom e=el mining

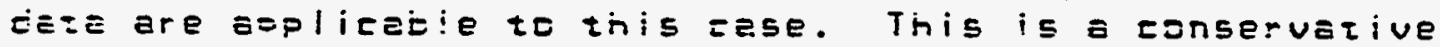
Essumidion because the uncortined comoressive strengtis ct ser.csizses (tive strata jeing minej) are usuaily ejout tcur times thet of coel. Subsidence at the site uould be oue to =i i ier tailure; with sisiner strengthss tailire wajid be iess likeiy for. sencistones then eDel uneer tie same =aneisisis.

The beem analesy for erecking (Lee and Shen) is epplicesie are the recen/inititratidr. barrier represents tine 5 i it iayer in the e=ver most susceftible to eracking. ire sliek Hoek zeilings are predamineirtiy cohesionless sancis thet weilit shit: in reponse to fourdaticn sutsidence but wello not ereak; tensile streirs wauld be trensierred to tite s=ver.

\section{DATA SOURLES:}

نmetca Minerais Corp. mine map ior tiseir Burro Canvon mine U.S. Gedidsical Survery Frafessienal Faper 576-A, "Strat:grasny, Siizk Rs=k Distriez and Vicinizy, Colc."

Slick Rock Geoicey Repdet tor proposes Burro Cenyen s:te (ipreparation) 


\section{CALCULATIONS:}

Evaluated previdus minins in the site area (Limet=s Minerais Corp.- about one mile to the southwest) to estimete tie

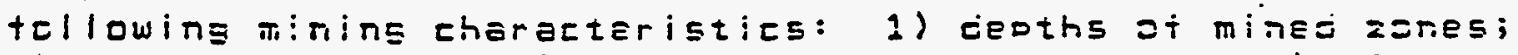
2) number oi zones 3) thickness of mined zaries; 4) wicths ot piliers and panels; ard 5) extrection retics. The toliouing conclusiors can be made as to reasonabie mining scenarios that coule potentieily effect e jisposai cell ai the Burro Cenyen site:

Ease Fanel wigth Piilar wieth Extraction ratio

$\frac{(t+)}{250} \frac{(t+)}{200} \frac{\left(y_{0}\right)}{20}$

3esed on the strike and dip of the 5 alt Wash (tine unic being mined and the jepth oi frevious minins, the estimeted deoti ot Dotential mining zones underneath the Burro Canyon $5 i \tau e$ wiil be 900 teet. Two potential ore zones, appraximateiy 50 teez e=ert ane less than tive teet thiek have been mined (minine equipment removec about ten teet of the ore bearine sand-stonel. For this anaiysis, two zanes with mirins tricknesses of ten teet $u i l l$ be used and the resulis superimpised. It migint be nated thet there wes res exiensive overlap of the two zones exeaveted ouring orevious mining in ine area. 
JACOBS ENGINEERING

Calculation No. SRK-04-90-03-03-00

$3 / 17$

DATE $4 / 16 / 90$

or JMM a arD.
SUBJECT SUBSIDENCE EVALUATION
SHER NO 200 no.
$3 / 17$

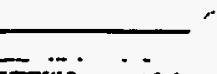

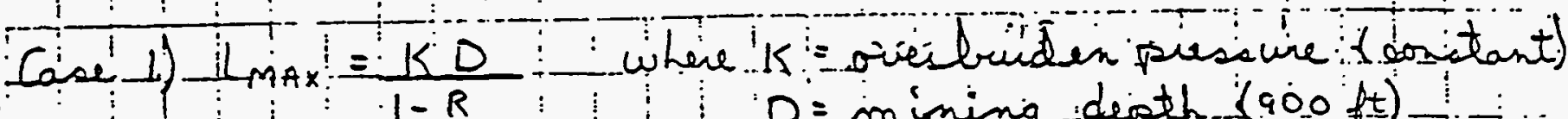
$D$ : mining depth $(900 \mathrm{ft})$

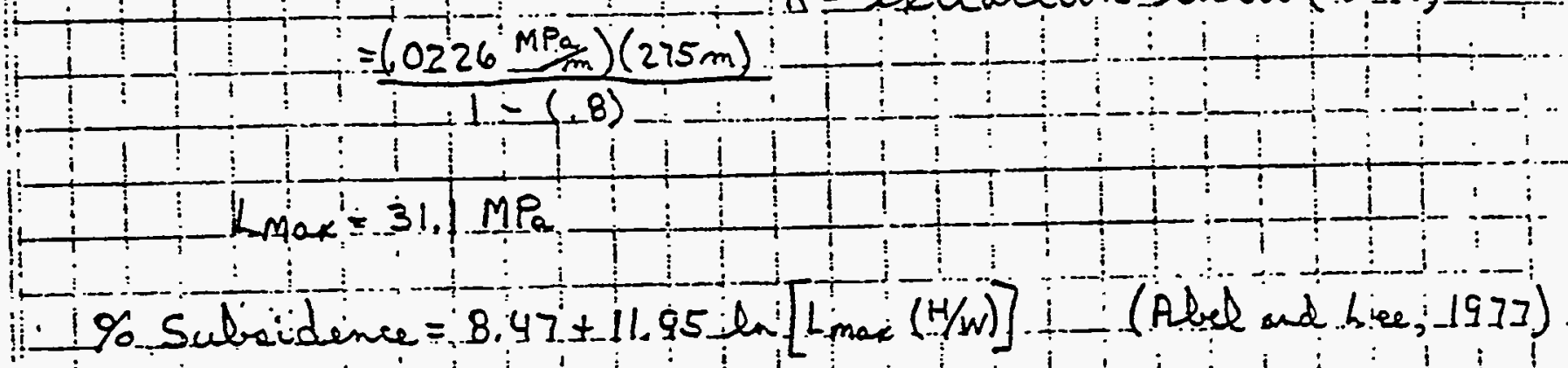$$
=8.47+11.95 \ln [31,1(3 \mathrm{~m} / 3 \mathrm{~m})]
$$$$
=49.5 \% \text { of mining height }
$$

use $50 \%$.

$H=$ mining height (10/t) $w$ : pillar width $(10 / t)$

Subsidence $(5)=5(10 \mathrm{ft})=5 \mathrm{ft}$

Pane convection factor

$$
\text { width }=61 \mathrm{~m} \text {. Depth }=275 \mathrm{~m}
$$

Fan Fig. 3 (NCB,1976) convection factor $=0.08$

Then $S_{\max }=.08(5 f t)=0.4 \mathrm{pt}$.

Limited face advance factor.

Face ad vance $(L)=2 W=2(61 \mathrm{~m})=122 \mathrm{~m}$ (Assumption) Depth $(H)=.275 \mathrm{~m}$

$$
L / H=122 \mathrm{~m} / 275=0.44
$$

From Fig. $4(N C B, 1976)$ factor $=0.4$

$\ddot{C}_{\text {erected }} S_{\text {max }}=0.4(.4 \mathrm{ft})=0.16 \mathrm{ft}$ 


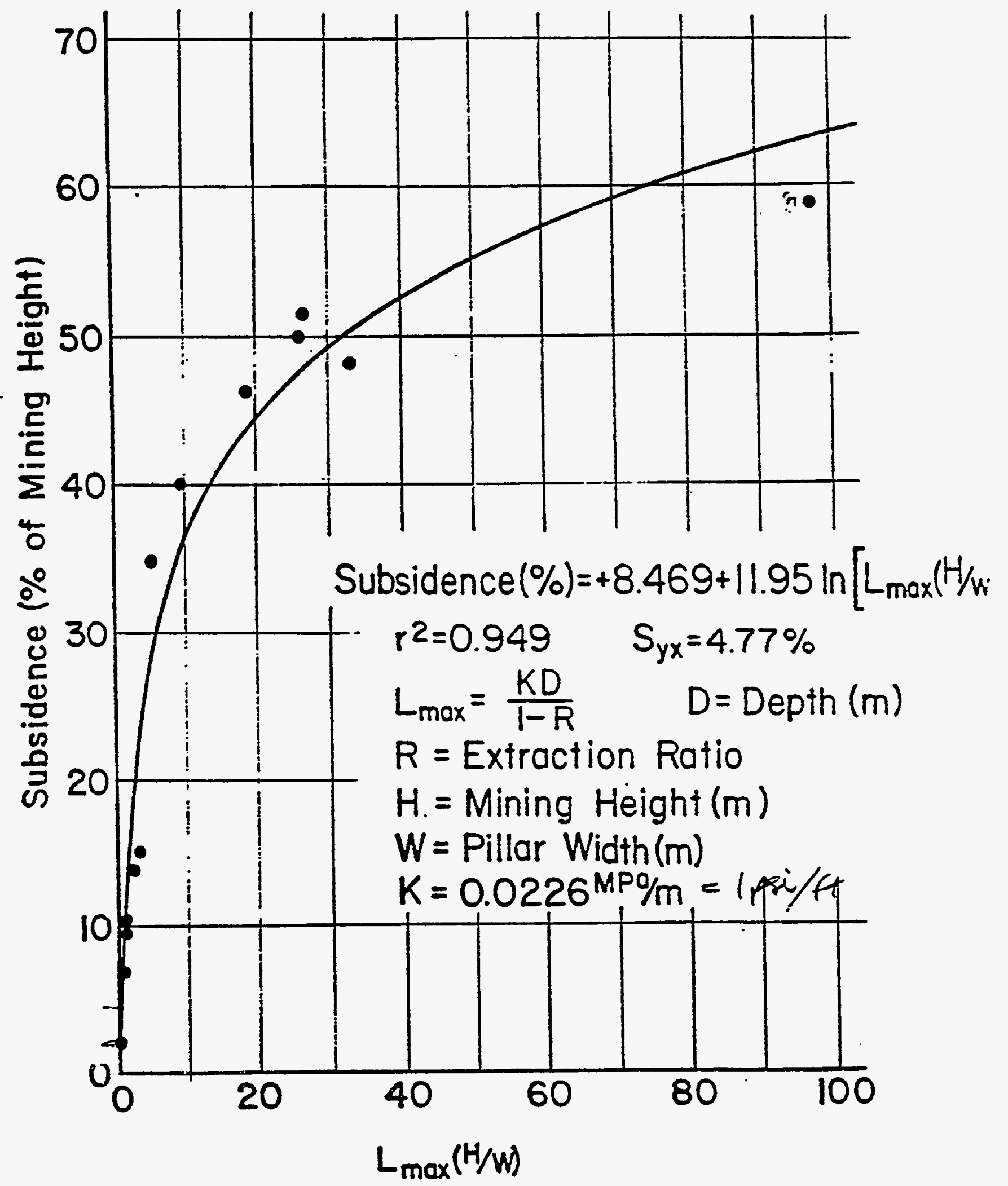

Figure 3. Subsidence above room-and-pillar workings following pillar squeeze or failure. 


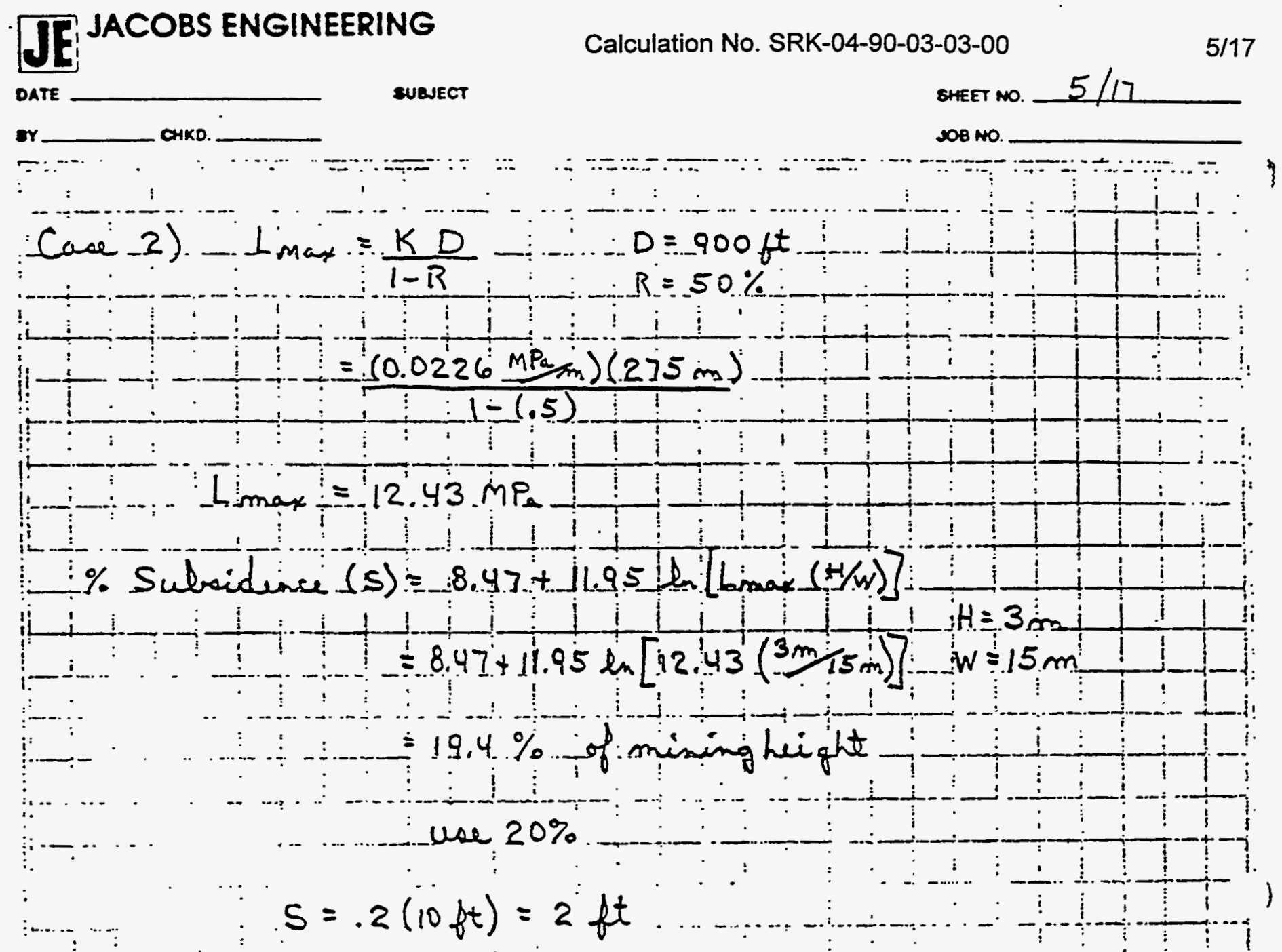

Pane Connection Factor

$$
\text { Width }=183 \mathrm{~m} ; \text { Depth }=275 \mathrm{~m}
$$

From Fig. $3(N C B, 1976)$ convection factor $=67$

Then $S_{\text {max }}=.67(2 \mathrm{ft})=1.34 \mathrm{ft}$.

Limited face advance is mot applicable

$$
S_{\text {max }}=1.34 f t
$$

Use 1.34 ft for max. subsidence

6 
TR JACOBS ENGINEERING

Calculation No. SRK-04-90-03-03-00

$6 / 17$

OATE $4 / 16 / 90$

SUENECT

SHEET MO. $6 / 17$

CHKD.

NOS NO.

ANGLE OF DRAW

Pusent iandstone in ouedying $10 \mathrm{ch} \approx 30 \%$

Fiom Fin 2 (Abel the A Angle of dow $=25^{\circ}$

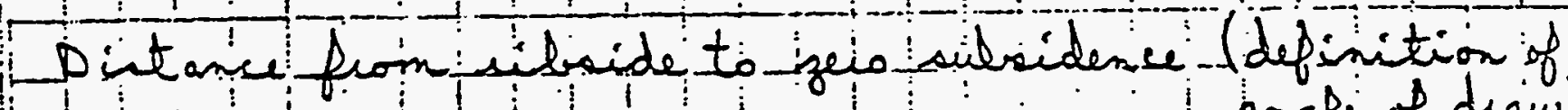

$$
\begin{aligned}
& =\tan \text { agle (Dept) } \\
& =\tan 25^{\circ}(900 \text { (ft) }
\end{aligned}
$$$$
=420 \text { ft }
$$
angle of -diaw)

Subidence Pafofide

Batio of Ponel: - WIDTH : 600 ft cheight $=900 \mathrm{ft}$

$$
\text { w/h }=600 / 900=67 \text { are } 68 \text { for Table I. (NCB, 1976) }
$$

$\alpha / s=$ atio of pridicted subidence to max subridence

Fiom Talle I (NCB, 1976)

O aubridence in expected 1.04 (height) away fiom pand $1.04(900 \mathrm{ft})-(300 \mathrm{ft})-300 \mathrm{ft}=\mathrm{y}_{2}$ pand width center line

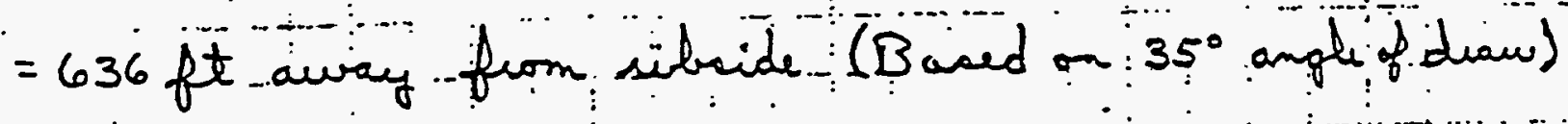

To counct pofile bo incurned anple of diaw (25 vo 350) - CAe s.to $3700 \mathrm{ft} / 636 \mathrm{ft}=366$

Subridencer predicted to occur at distancer less than one-hatf of the panel width do mot have to be couccted, ie.

7 


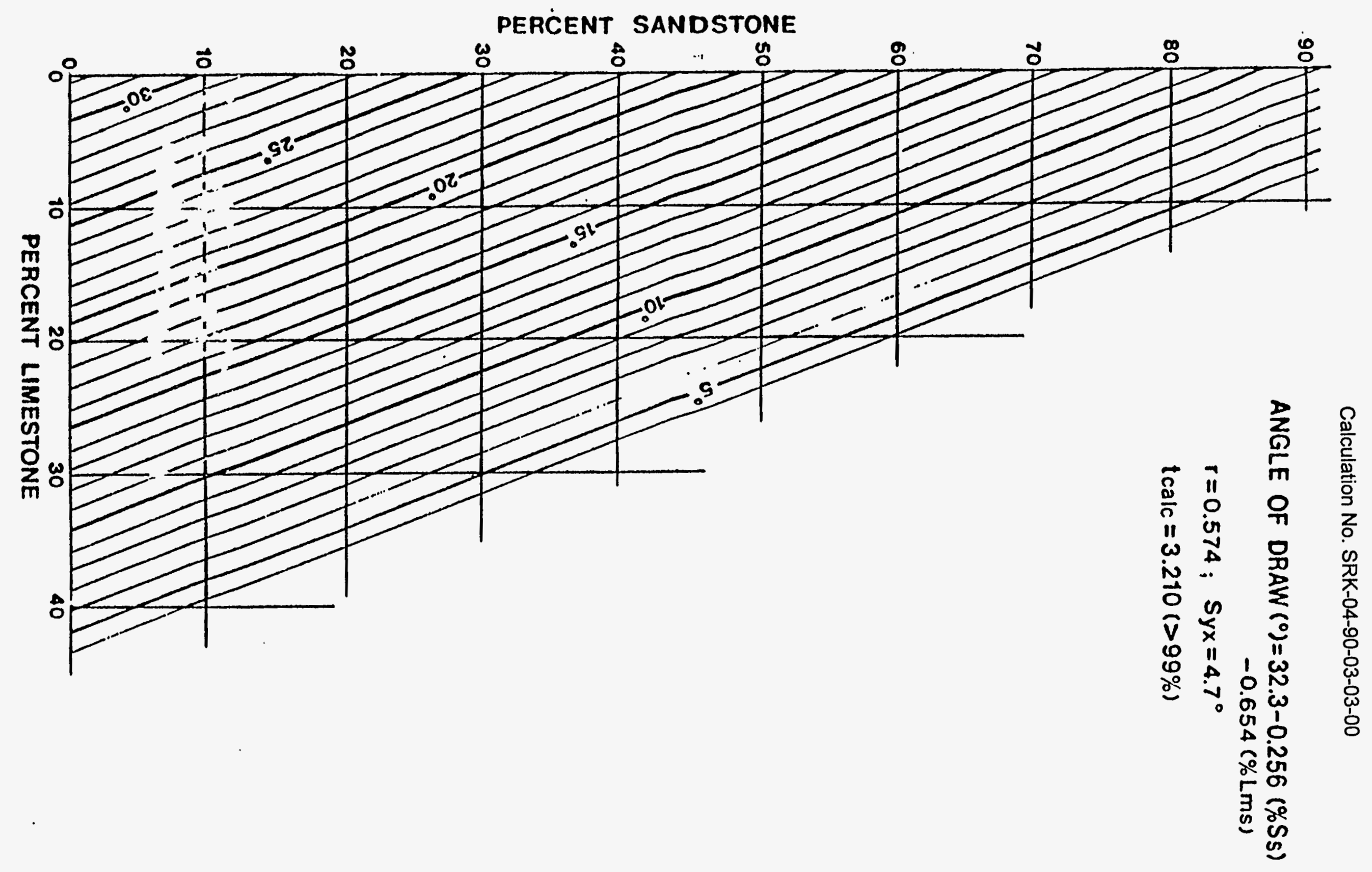




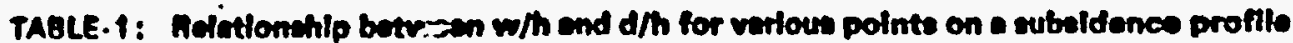

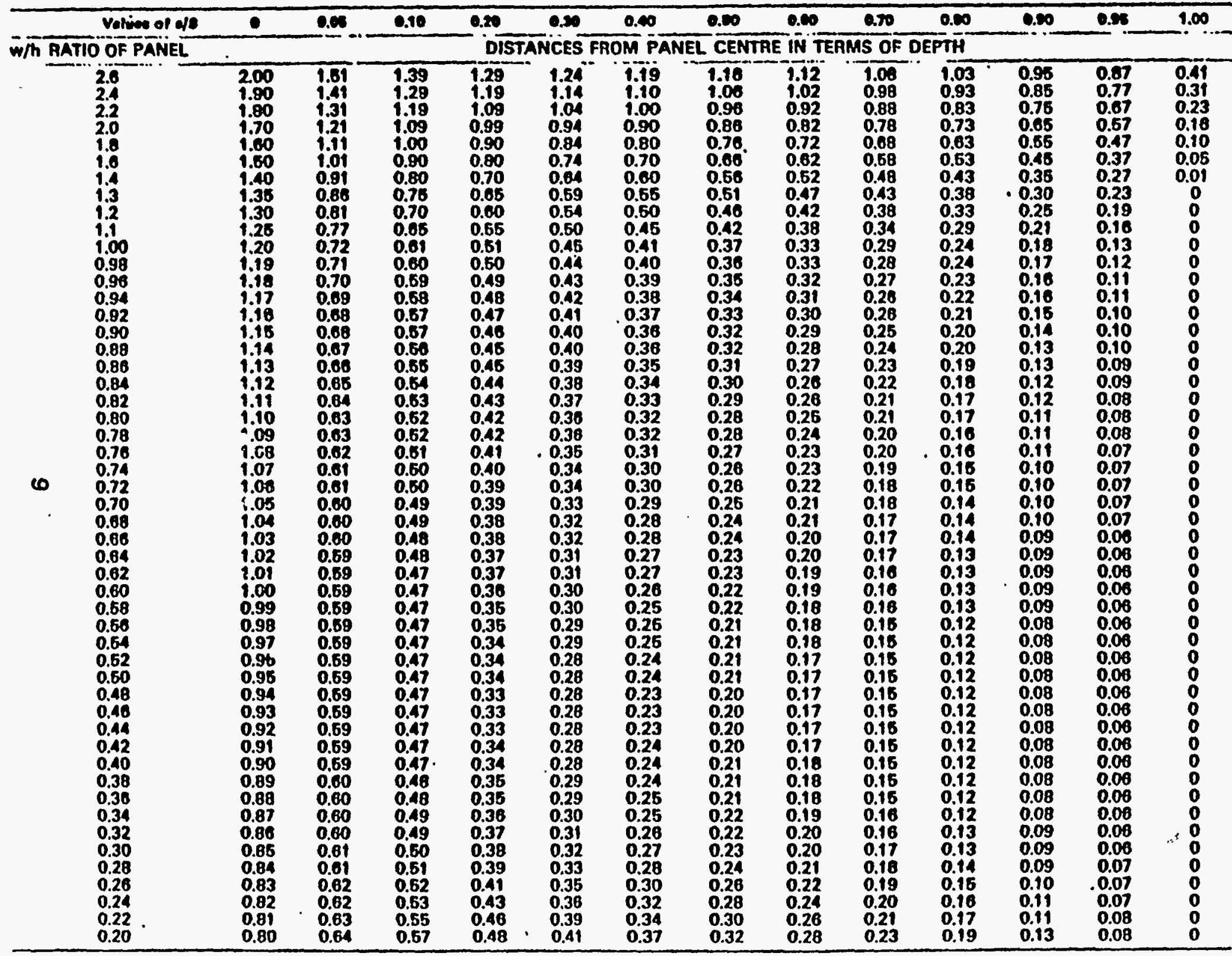


$=-1=-1=$

$=189^{\circ}$

$=-111^{\prime}$

$=-147^{\circ}$

$(.17)$

$=153^{\prime}$

$=-174$

.80

$(.14)$

$=126^{\circ}$

$(.10)$

$=90^{\prime}$

$=-210$

.95

$(.07) \downarrow=63^{\circ}$

$=-237$

Max alope occus from $1 / 5: 0.3$ to 0.8 whe $s=1.34$ ft Slope $=\frac{(.8-.3)\left(1.34^{\prime}\right)}{-174^{\prime}-\left(-12^{\prime}\right)}=\frac{.67^{\prime}}{162^{\prime}}=.004 \mathrm{ft} / \mathrm{ft}$ for ione $10^{\prime}$ : one 
JACOBS ENGINEERING

Calculation No. SRK-04-90-03-03-00

$10 / 17$

DATE

SWEET

:

SHEET NO. SOB NO

$10 / 17$

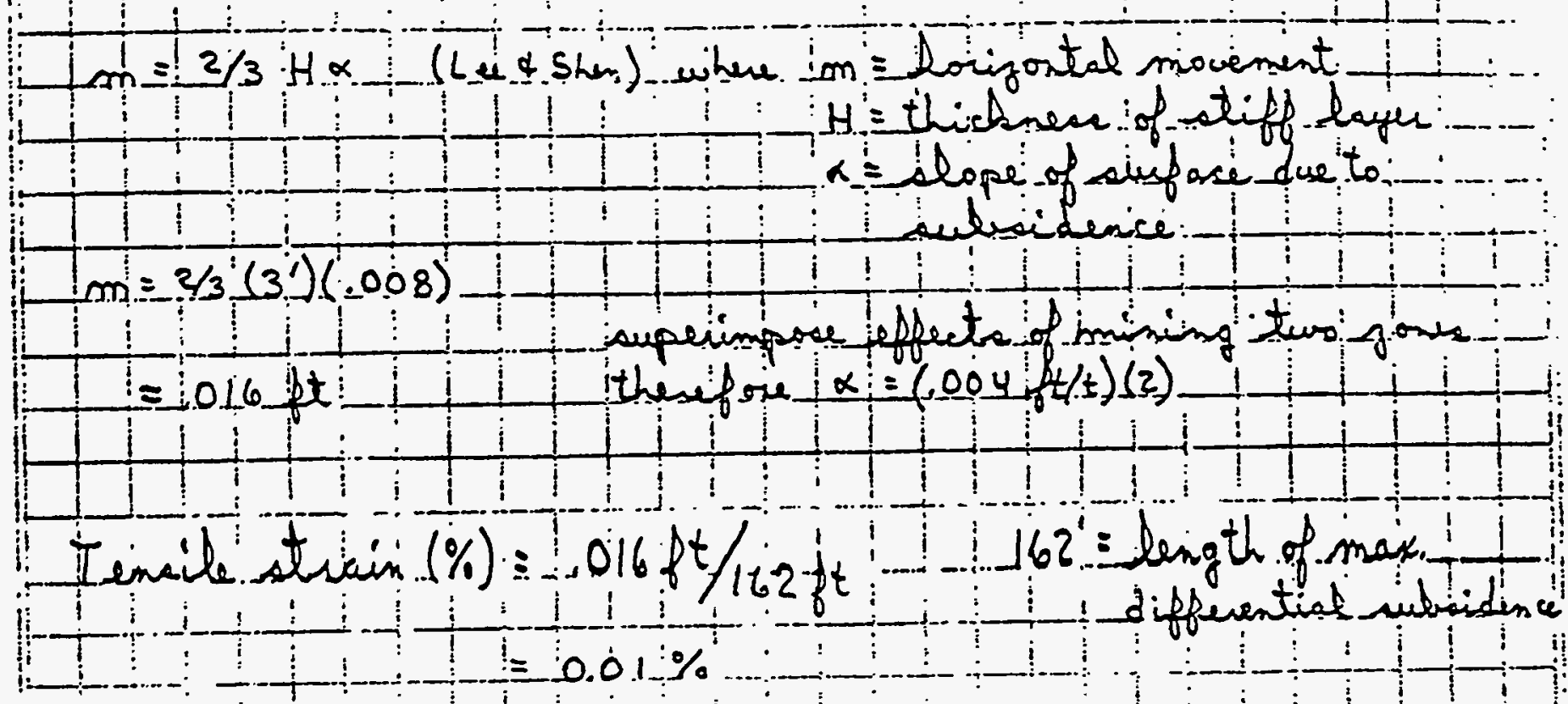

From Leonard thaiain $(1963), 0.05 \%$ was the bo west tensile trains that resulted in cracking of any soil types tested . $01 \% \ll .05 \%$ Then fore, the most sea Son able, potential mining scenario in the vicinity of the proposed disposal 1 that could cave subsidence would be well below the threshold of potential damage to the cell cover.

11 
JACOBS ENGINEERING

Calculation No. SRK-04-90-03-03-00

$11 / 17$

DATE

BY CHKD.
SELECT
SHEET No. $1 / 1 / 7$

$\infty \mathrm{NO}$

Most consecutive case

Assume sam mining thichses (sm) number of gone $(2)$

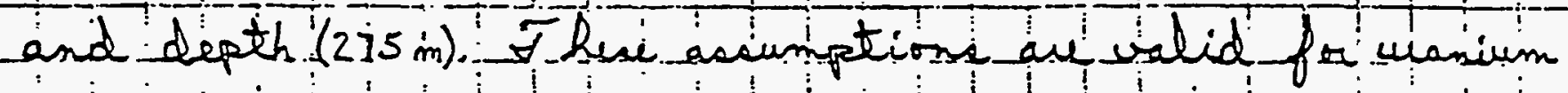
and indium sining previous conducted in the lech

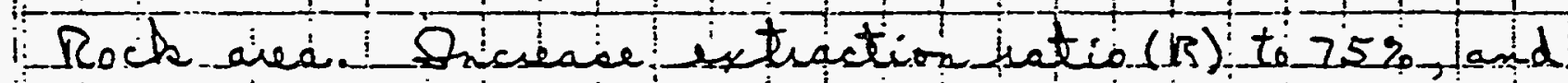

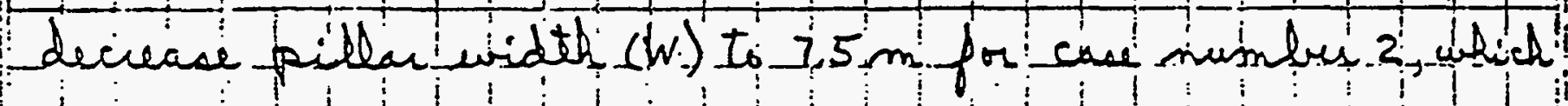

was the worst: case analyzed

$$
\begin{aligned}
& I_{\text {max }}=\frac{K O}{1-R}=\frac{(0226 \mathrm{MPa} / \mathrm{m})(275)}{1 \div .75 \quad 24.86 \mathrm{MPa}} \\
& \% S \text { ibaidence }=8.47+11.95 \ln \left[L_{\max }(3 / 7.5)\right. \\
& =35.9 \% \\
& s=.36\left(10^{\circ}\right)=3,6
\end{aligned}
$$

Panel correction factor $=-67$

$$
\therefore S_{\text {max }}=.67\left(3.6^{\prime}\right)=2.4 \mathrm{ft}
$$

Same subsidence profile ie applicable, determine slope for $a / s$ for .3 to .8

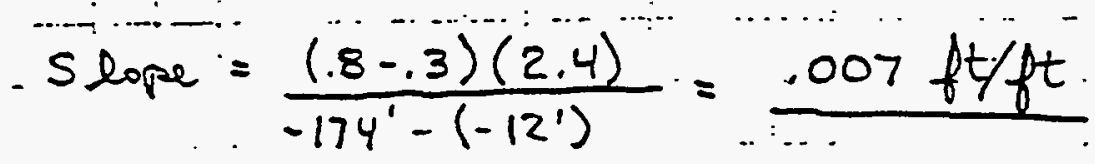

(for one zone mined)

12 
JACOBS ENGINEERING

oATE

SUENCT

Calculation No. SRK-04-90-03-03-00

$12 / 17$

or CHKD.

SHEET NO. $12 / 17$ 200 No.

Ciaking potential

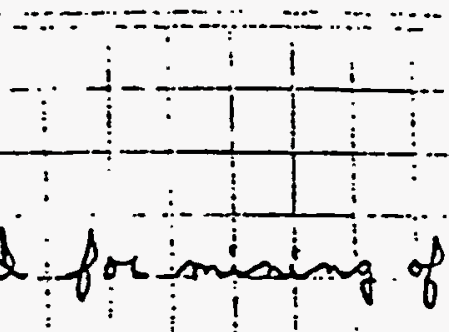

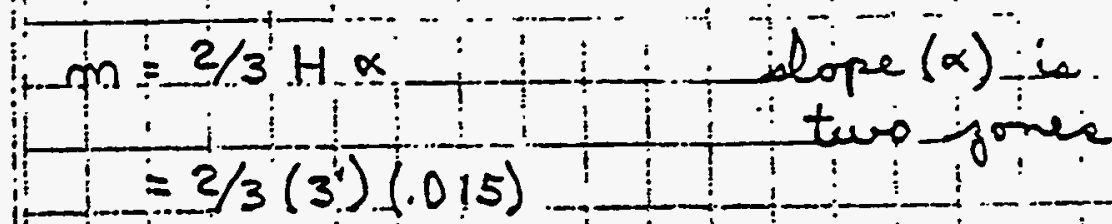

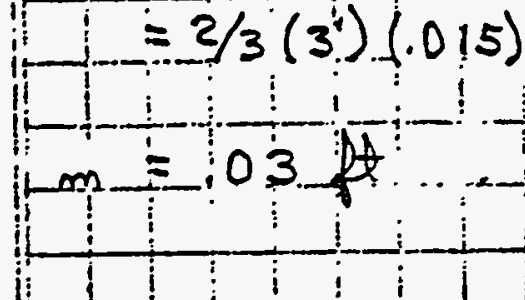

Tencide stiain $(\%)=0.03 \mathrm{ft}$

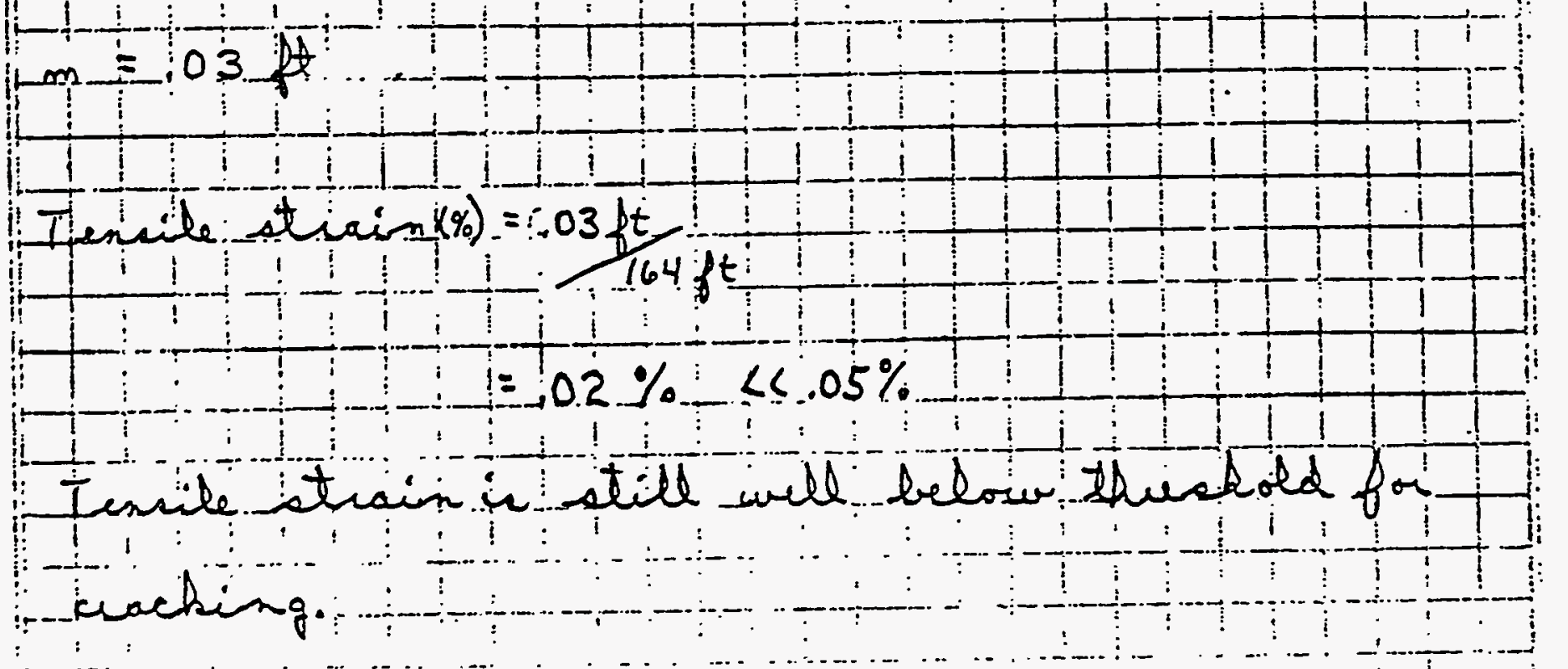

Tencle stusin still well below thichold for ichaching. 
CONCLLLICNS :

Zesed $c$ R peviajs mining in the area anc using ezrservative essumptions ter aneiysis, potential minins ot tine woser jelt Wesh formazian tor urenium and venadium uoult rict adverseiy aftect the lons-term stability of the proposed ojisojsei ceil at Burra Canyon. In orier to cause an impact to the integrity of tine disposal cell cover, undergeround minirg wivic have to be much closer to the surtece. Presently, tinere are no known economice! ore defosits in either tre 3urro Canyon or Merrison Formatian in the vicinity ci the proocsed Burro Canyon site. These are the tormations overiying the Salt liash. 


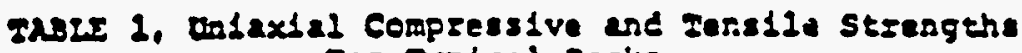
For Typleal Rocks

(raster, 2963 and Jueger Cook, 1969)

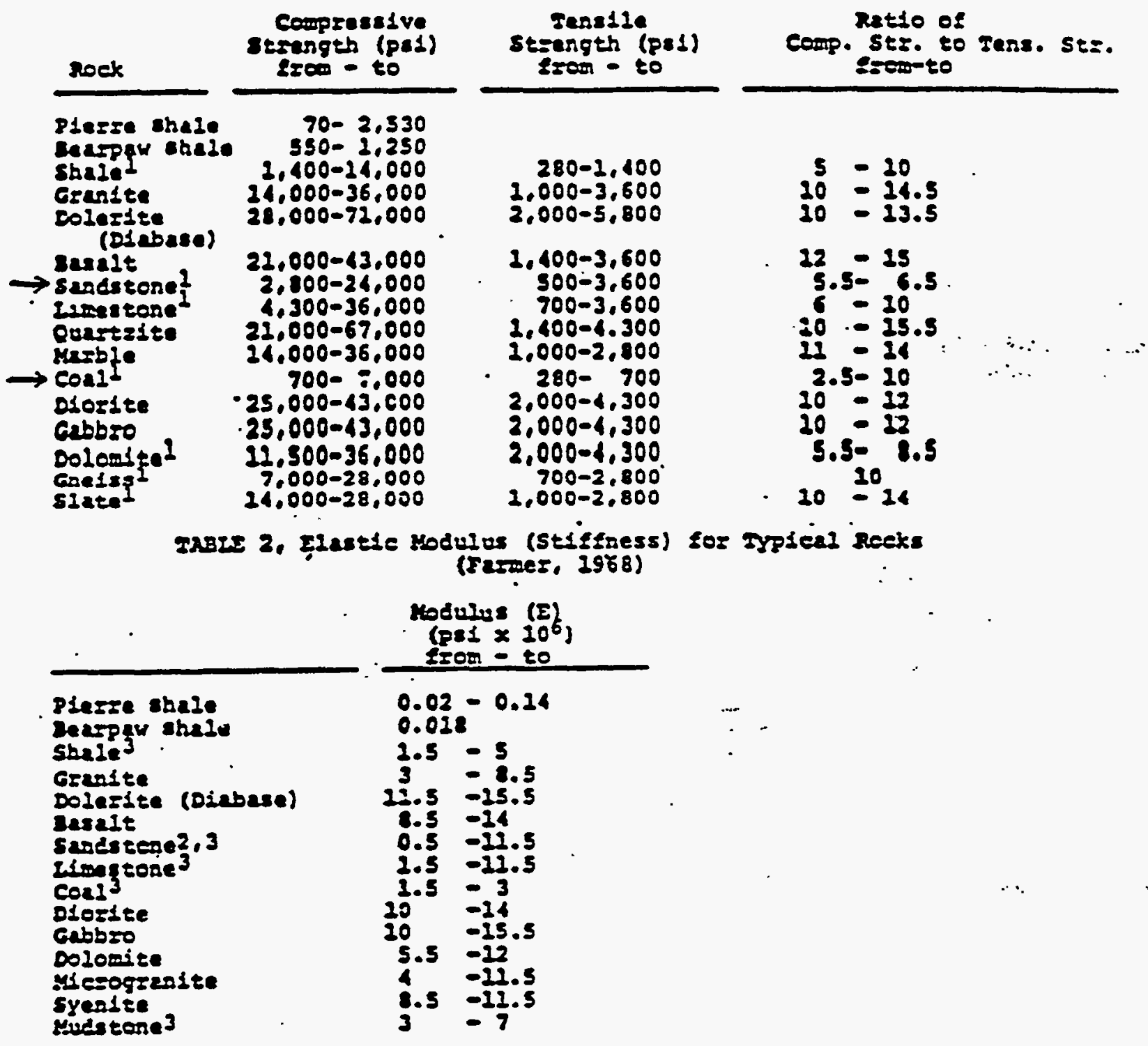

Hotes, I geasdle serength cesess bedding and(or) lollation any to too $10 \mathrm{w}$ to seasure.

2 crats pecking any be estescal.

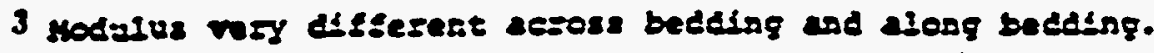




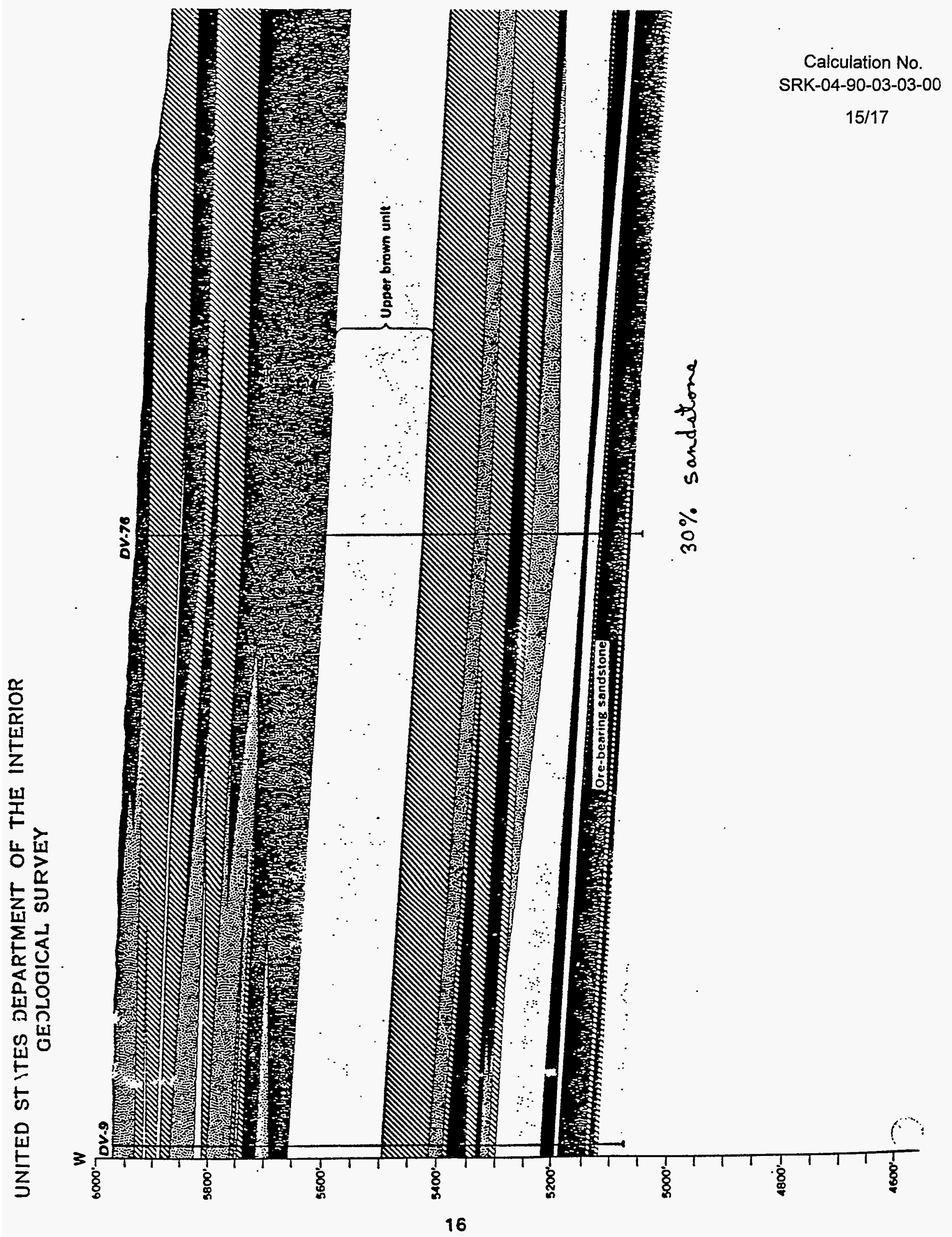




\section{EXPLANATION}

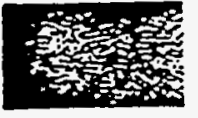

Light-gray or light-buff andstone

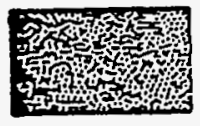

Light-reddish-brown andstone

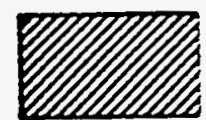

Hostly greenish-gray mudstone

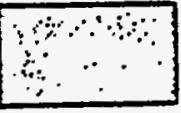

Sostly reddish-brown mudstone
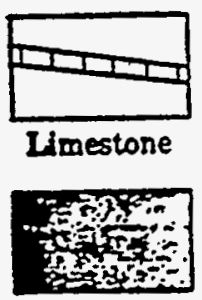

Carbonsceous shale

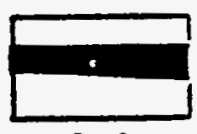

Conl

DV-119

Dismond-drill bole number

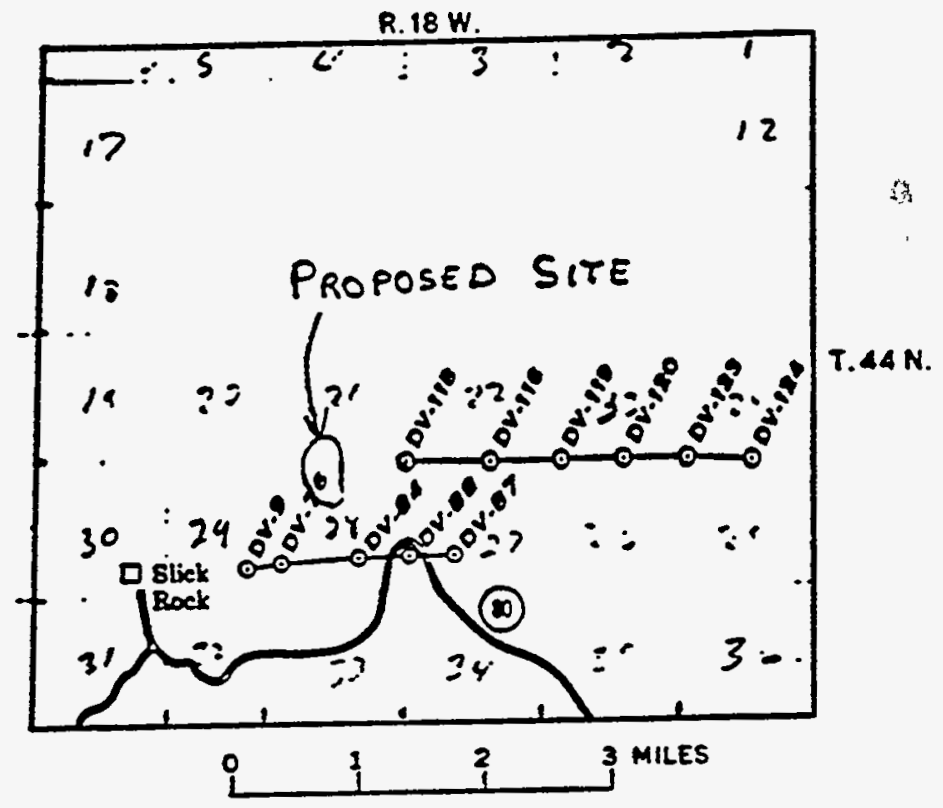

LOCATION OF SECTIONS 


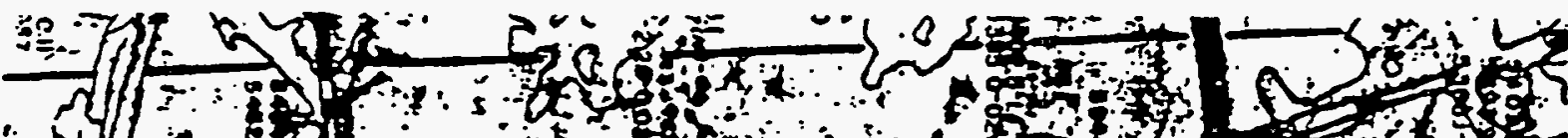

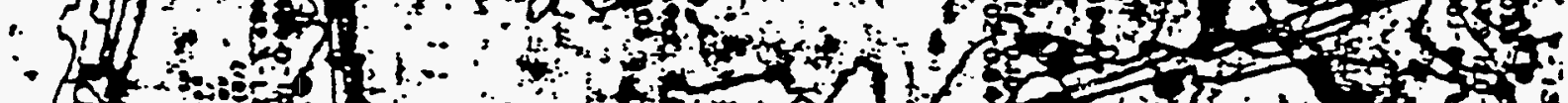

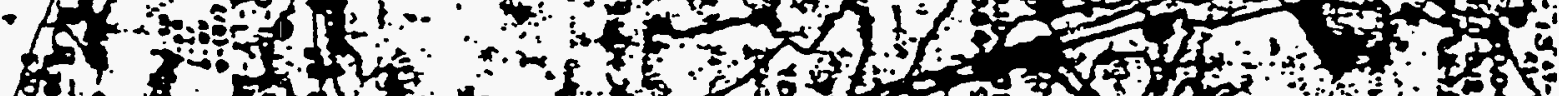

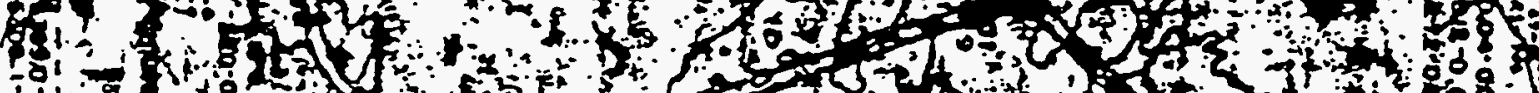
ó sis of on

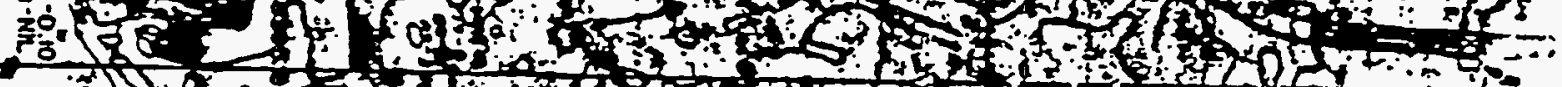
efins ó

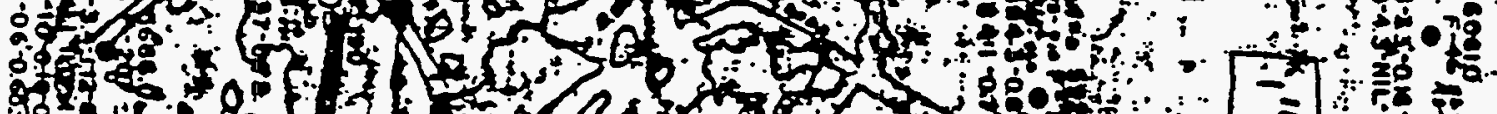

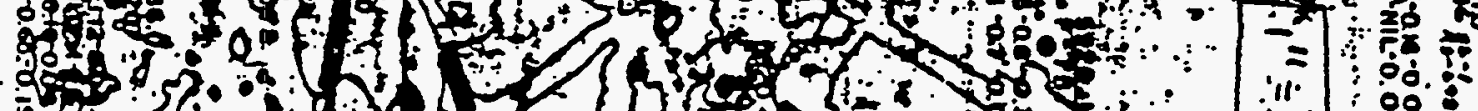
-

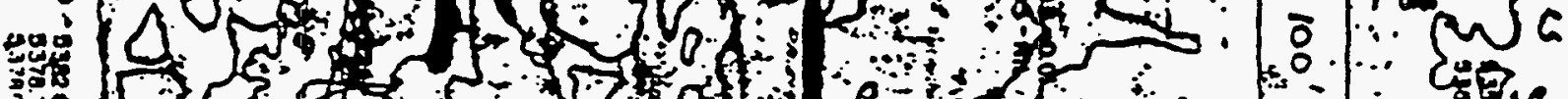

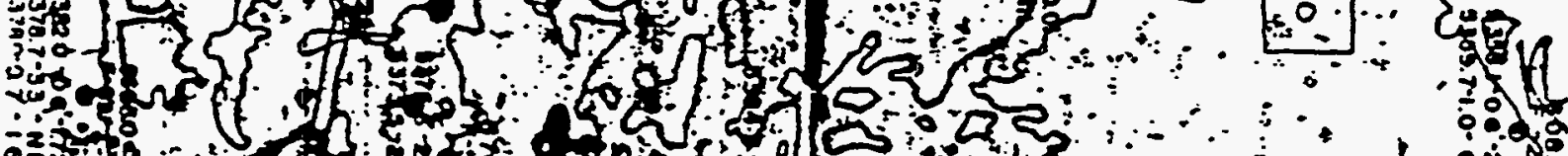

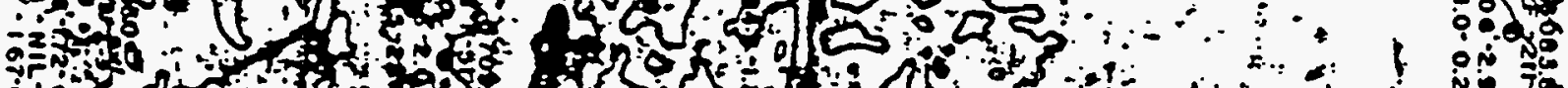

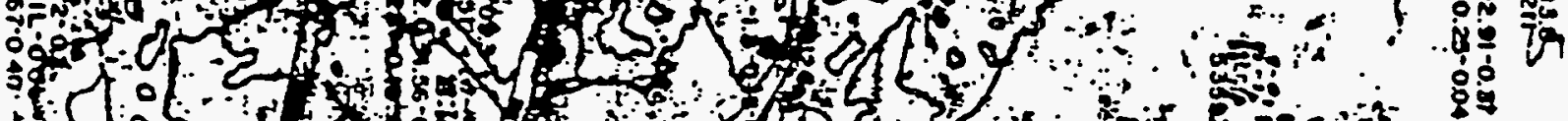

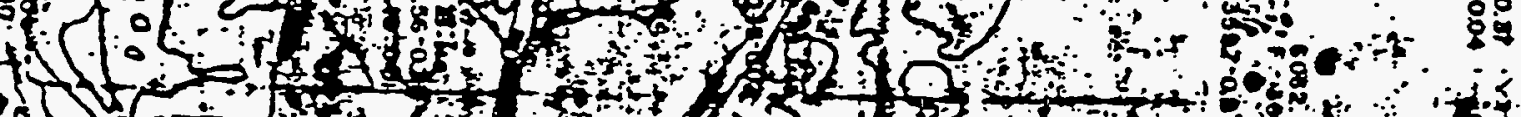

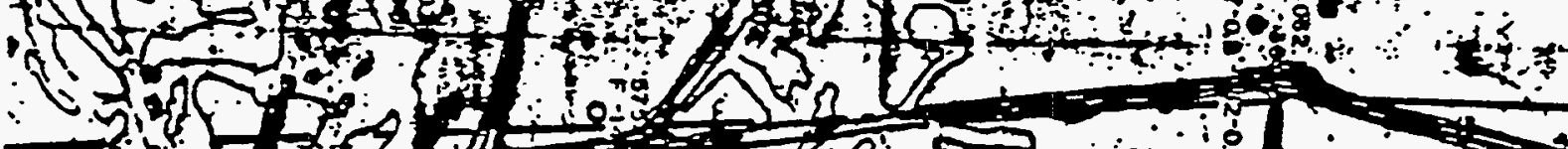

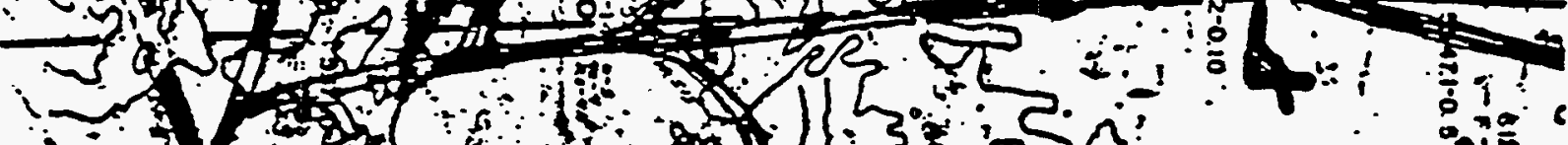
20

20 -

Pat

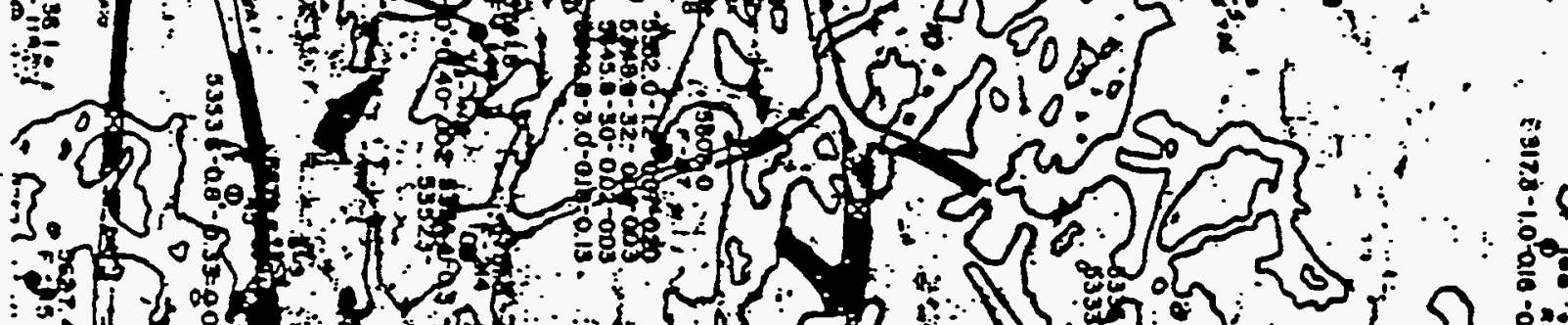

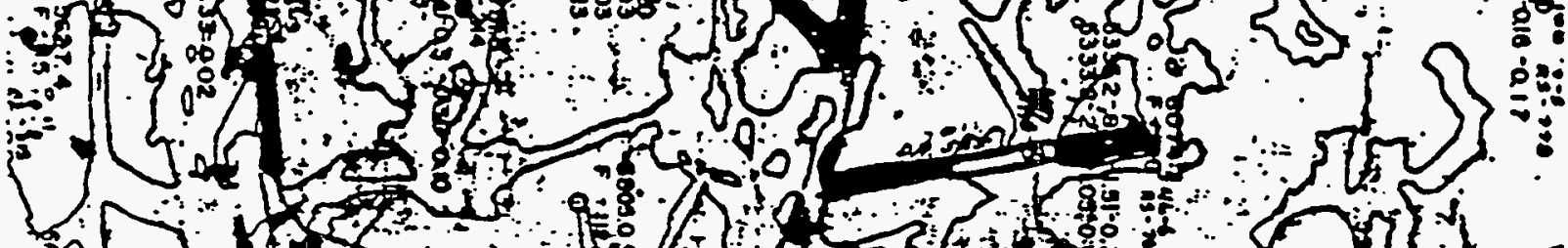

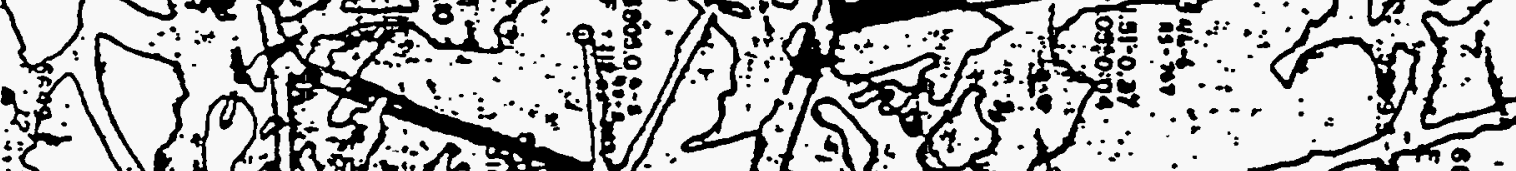

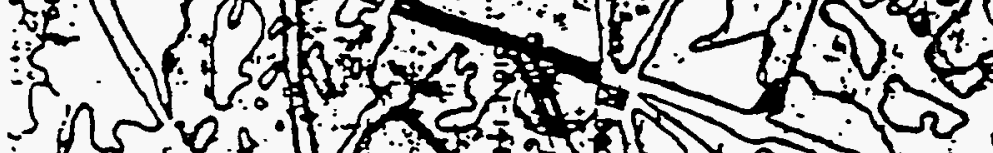

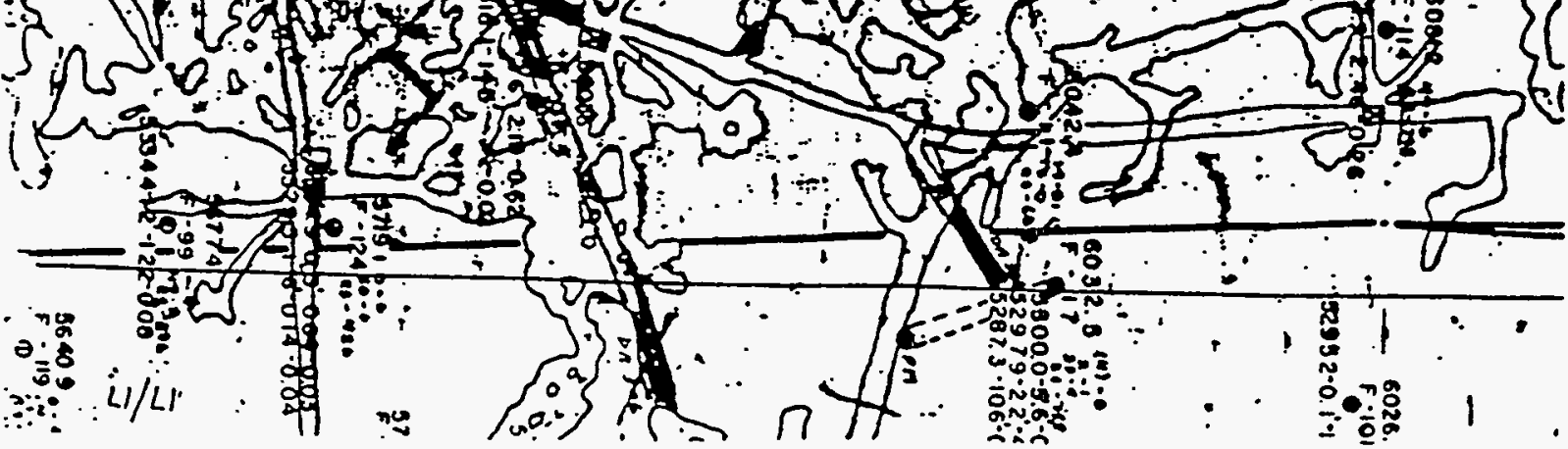

(1) 
TABLE OF CONTENTS

Section

Page

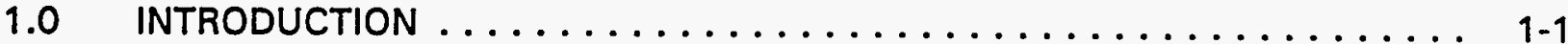

2.0 HYDROGEOLOGICAL SITE CHARACTERIZATION SUMMARY . . . . . . . . 2-1

2.1 Slick Rock North Continent and Union Carbide processing sites . . . . . . 2-1

2.2 Burro Canyon disposal site ....................... 2-2

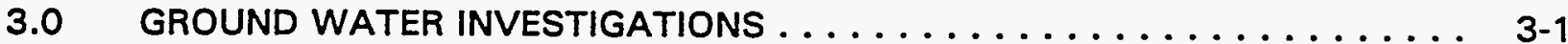

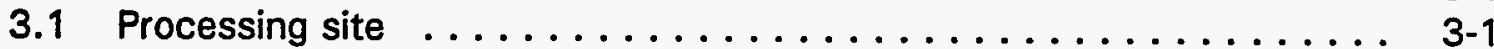

3.1.1 Previous investigations ................. 3-1

3.1.2 Geology and hydrostratigraphy ............... 3-2

3.1.3 Occurrence of ground water ................ 3-5

3.1.4 Hydraulic characteristics ................. 3-12

3.1.5 Background ground water quality ............. 3-15

3.1.6 Tailings and milling process characterization ......... 3-20

3.1.7 Extent of ground water contamination . . . . . . . . . . . 3-24

3.1.8 Geochemical conditions . . . . . . . . . . . . . . 3-35

3.1.9 Ground water use, value, and alternative supplies . . . . . 3-37

3.2 Disposal site ............................ 3-38

3.2.1 Previous investigations $\ldots \ldots \ldots \ldots \ldots \ldots \ldots \ldots \ldots \ldots . \ldots \ldots$

3.2.2 Geology and hydrostratigraphy ............... 3-41

3.2.3 Presence and movement of ground water .......... $3-43$

3.2.4 Hydraulic characteristics ................. 3-50

3.2.5 Background ground water quality ............. . 3-52

3.2.6 Ground water use, value, and alternative supplies . . . . . 3-56

$4.0 \quad$ REFERENCES $\ldots \ldots \ldots \ldots \ldots \ldots \ldots \ldots \ldots \ldots \ldots \ldots \ldots \ldots \ldots$

APPENDIX A TABLES

APPENDIX B LITHOLOGIC LOGS

APPENDIX C CALCULATIONS 


\section{LIST OF FIGURES}

3.1 Ground water and surface water sampling locations near Slick Rock,

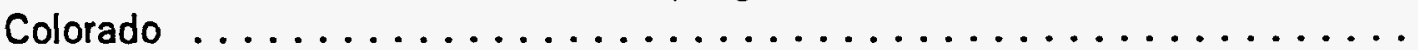

3.2 Geologic cross section (northwest-southeast), NC and UC sites near Slick Rock, Colorado . . . . . . . . . . . . . . . . . . . . . . 3-4

3.3 Water table contour map for the Dolores River alluvial wells, NC and UC sites near Slick Rock, Colorado . . . . . . . . . . . . . . . . . 3-7

3.4 Ground water hydrograph of the Dolores River alluvium, UC processing site near Slick Rock, Colorado . . . . . . . . . . . . . . . . . 3-8

3.5 Ground water hydrograph of the Dolores River alluvium, NC processing site near Slick Rock, Colorado . . . . . . . . . . . . . . . . . . . . 3-9

3.6 Potentiometric surface contour map of Entrada Formation wells, UC processing site near Slick Rock, Colorado . . . . . . . . . . . . . . . 3-10

3.7 Ground water hydrograph of the Entrada Formation, UC processing site near Slick Rock, Colorado . . . . . . . . . . . . . . . . . . . . . . 3-11

3.8 Potentiometric surface contour map of Navajo Sandstone wells near Slick Rock, Colorado . . . . . . . . . . . . . . . . . . . . . . . . . 3-13

3.9 Ground water hydrograph of the Navajo Sandstone, NC and UC sites near Slick Rock, Colorado . . . . . . . . . . . . . . . . . . . . . . . . . . . 3-14

3.10 Sulfate distribution in alluvial ground water near Slick Rock, Colorado ... . . . . . . . . . . . . . . . . . . . . . . 3-26

3.11 Molybdenum distribution in alluvial ground water near Slick Rock, Colorado . . . . . . . . . . . . . . . . . . . . . . . . . . .

3.12 Nitrate distribution in alluvial ground water near Slick Rock,

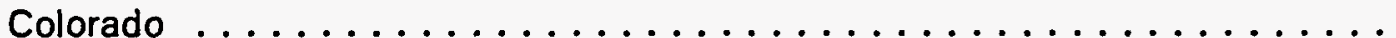

3.13 Uranium distribution in alluvial ground water near Slick Rock, Colorado ..................................

3.14 Monitor well locations, Burro Canyon disposal site near Slick Rock, Colorado ................................

3.15 Geologic cross section (northwest-southeast), Burro Canyon disposal site near Slick Rock, Colorado . . . . . . . . . . . . . . . . . . . .

3.16 Potentiometric surface of the Burro Canyon upper sandstone unit, Burro Canyon disposal site near Slick Rock, Colorado . . . . . . . . . . . . . . . 3-44

3.17 Ground water hydrograph of the Burro Canyon upper sandstone unit, Burro Canyon disposal site near Slick Rock, Colorado . . . . . . . . . . . . . . 3-45

3.18 Potentiometric surface of the Burro Canyon middle sandstone unit, Burro Canyon disposal site near Slick Rock, Colorado . . . . . . . . . . . . . . .

3.19 Ground water hydrograph of the Burro Canyon middle sandstone unit, Burro Canyon disposal site near Slick Rock, Colorado . . . . . . . . . . . . . . 3-47

3.20 Potentiometric surface of the Burro Canyon lower sandstone unit, Burro Canyon disposal site near Slick Rock, Colorado . . . . . . . . . . . . . . . 3-48

3.21 Ground water hydrograph of the Burro Canyon lower sandstone unit, Burro Canyon disposal site near Slick Rock, Colorado . . . . . . . . . . . . . 


\section{LIST OF ACRONYMS}

$\begin{array}{ll}\text { Acronym } & \text { Definition } \\ \text { BLM } & \text { Bureau of Land Management } \\ \text { CDPHE } & \text { Colorado Department of Public Health and Environment } \\ \text { DOE } & \text { U.S. Department of Energy } \\ \text { EPA } & \text { U.S. Environmental Protection Agency } \\ \text { MCL } & \text { maximum concentration limit } \\ \text { MSL } & \text { mean sea level } \\ \text { NC } & \text { North Continent } \\ \text { NEPA } & \text { National Environmental Policy Act } \\ \text { RAP } & \text { remedial action plan } \\ \text { RRM } & \text { residual radioactive materials } \\ \text { SPEAR } & \text { Software Program for Environmental Analysis and Reporting } \\ \text { TAD } & \text { Technical Approach Document } \\ \text { TDS } & \text { total dissolved solids } \\ \text { UC } & \text { Union Carbide } \\ \text { UMTRA } & \text { Uranium Mill Tailings Remedial Action } \\ \text { UMTRCA } & \text { Uranium Mill Tailings Radiation Control Act } \\ \text { USGS } & \text { U.S. Geological Survey } \\ \text { VP } & \text { vicinity property } \\ \text { WHIP } & \text { Well Hydraulics Interpretation Program }\end{array}$




\subsection{INTRODUCTION}

The U.S. Environmental Protection Agency (EPA) has established health and environmental protection regulations to correct and prevent ground water contamination resulting from processing activities at inactive uranium milling sites (60 FR 2854). According to the Uranium Mill Tailings Radiation Control Act (UMTRCA) (42 USC $\$ 7901$ et seq.), the U.S. Department of Energy (DOE) is responsible for assessing the inactive uranium processing sites. The DOE has determined that for Slick Rock, this assessment shall include hydrogeologic site characterization for two separate uranium processing sites, the Union Carbide (UC) site and the North Continent (NC) site, and for the Burro Canyon disposal site. The water resources protection strategy that describes how the proposed action will comply with the EPA ground water protection standards is presented in Attachment 4. The following site characterization activities are discussed in this attachment:

- Characterization of the hydrogeologic environment, including hydrostratigraphy, ground water occurrence, aquifer parameters, and areas of recharge and discharge.

- Characterization of existing ground water quality by comparison with background water quality and the maximum concentration limits (MCL) of the EPA ground water protection standards.

- Definition of physical and chemical characteristics of the potential contaminant source, including concentration and leachability of the source in relation to migration in ground water and hydraulically connected surface water.

- Description of local water resources, including current and future use, availability, and alternative supplies.

The EPA promulgated final ground water protection standards for the disposal and cleanup of the inactive uranium processing sites under the UMTRCA on 5 January 1983. However, the ground water provisions of the regulations (40 CFR \$192.20(a)(2)-(3)) were remanded back to the EPA by the U.S. Court of Appeals for the Tenth Circuit on 3 September .1985. The EPA issued final ground water standards (60 FR 2854) on 11 January 1995. Table 1.1 of Appendix A summarizes these standards.

Evaluation of aquifer restoration and control of existing ground water contamination at the Slick Rock UC and NC processing sites will be addressed under a separate phase in accordance with the National Environmental Policy Act (NEPA). 


\subsection{HYDROGEOLOGICAL SITE CHARACTERIZATION SUMMARY}

The DOE has characterized the hydrogeology, water quality, and water resources at the Slick Rock UC and NC processing sites and the Burro Canyon disposal site. Major points are summarized below.

\subsection{SLICK ROCK NORTH CONTINENT AND UNION CARBIDE PROCESSING SITES}

The sites are located approximately 1 mile (mi) (2 kilometers [km]) from each other, along the banks of the Dolores River. Ground water conditions in the Slick Rock area are highly dependent on local topographic and stratigraphic structural features. Canyon cutting, tectonic fracturing, and discontinuities between the geologic formations may have caused distinct stratigraphic units to become hydraulically connected based on lithologic log data and ground water levels. Additional information is provided in Section 3.1.2.

The uppermost aquifer at the UC and NC sites consists of Dolores River alluvium, underlain by Entrada Sandstone (Slick Rock and Dewey Bridge Members) and Navajo Sandstone. These three hydrostratigraphic units are unconfined to confined, have variable permeabilities, and may be hydraulically connected.

Ground water flow is unconfined in the Dolores River alluvium and is expected to be semiconfined to confined in the underlying Entrada Sandstone and Navajo Sandstone Formations. Ground water elevations in the alluvium, Entrada Sandstone, and Navajo Sandstone have remained relatively constant over the past 4 years, regardless of the season. Details regarding ground water occurrence and the hydraulic characteristics of these formations are provided respectively in Sections 3.1.3 and 3.1.4.

Background ground water quality is defined as the quality of ground water that would be expected at the site if uranium processing had not occurred. Concentrations or activities of chromium, molybdenum, uranium, and radium (Ra-226 and -228) have exceeded the MCLs listed in 40 CFR Part 192 of the EPA final ground water standards in one or more background alluvial monitor wells.

The chemical characteristics of the NC and UC tailings materials were evaluated by pore fluid sampling with suction lysimeters. The $\mathrm{pH}$ of the tailings pore fluid is near-neutral, ranging from 6.2 to 7.8. Total dissolved solids (TDS) range from approximately 2400 to 33,900 milligrams per liter $(\mathrm{mg} / \mathrm{L})$. Average concentrations of arsenic, cadmium, molybdenum, selenium, and uranium exceeded the MCLs in lysimeter samples collected from the NC site. At the UC site, the average pore fluid concentrations of cadmium, molybdenum, nitrate, selenium, and uranium exceeded MCLs. 
On-site and downgradient (baseline) water quality has been compared to background ground water quality. Average TDS concentrations in baseline alluvial ground water are approximately three times those of background. The hazardous constituents of concern in the Dolores River alluvium are molybdenum, nitrate, selenium, and uranium at the UC processing site and selenium and uranium at the NC processing site. The baseline water quality of the Entrada Formation also appears to be affected by uranium processing activities because 1) the average concentrations of TDS in baseline Entrada Formation monitor wells are approximately three times those observed in background Entrada Formation monitor wells and 2) concentrations of selenium exceed the MCL and background. Baseline water quality in the Navajo Sandstone does not appear to be affected by processing activities. TDS, pH, and the regulated constituents show minimal variation between background and baseline water quality.

Eighteen private wells exist (currently or historically) within $2 \mathrm{mi}(3 \mathrm{~km}$ ) of the Slick Rock tailings sites; however, none of these wells are expected to be affected by the tailings materials at the Slick Rock processing sites, for the reasons discussed in Section 3.1.9.

\subsection{BURRO CANYON DISPOSAL SITE}

One unsaturated unit and three saturated units are present below the Burro Canyon disposal site. The unsaturated unit immediately underlying the site consists of the Dakota Sandstone and mudstones of the Burro Canyon. The tops of the three saturated sandstone units generally begin at approximate depths of 100, 200, and 300 feet ( $\mathrm{ft})(30,60$, and 90 meters [m]). These units are described as the upper, middle, and lower units, respectively. Each unit is composed of fine- to medium-grained sandstone layers and is 25 to $75 \mathrm{ft}(7.6$ to $23 \mathrm{~m}$ ) thick. The units are hydrogeologically separated from each other by interbedded mudstone and siltstone sequences. Additional information is provided in Section 3.2.2.

The upper sandstone unit of the Burro Canyon Formation is the first saturated unit and is the uppermost aquifer at the Burro Canyon disposal site. The upper sandstone unit has limited use ground water, as defined in 40 CFR $\$ 192.11$ (e) of the EPA final ground water standards, meaning that ground water is not a current or potential source of drinking water because the quantity of water available is less than 150 gallons per day (gpd) $\left(6.6 \times 10^{-3}\right.$ liters per second $[\mathrm{L} / \mathrm{s}])$. Pumping tests were conducted in wells screened in the upper sandstone unit; however, the wells could not sustain the 150-gpd $\left(6.6 \times 10^{-3} \mathrm{~L} / \mathrm{s}\right)$ rate for an extended period of time. The middle sandstone unit of the Burro Canyon Formation is a confined aquifer that is separated from the upper sandstone unit by approximately 60 to $70 \mathrm{ft}(17$ to $23 \mathrm{~m})$ of mudstone. The middle sandstone unit has a substantial upward vertical hydraulic gradient. Ground water in the lower sandstone unit is also confined by a thick sequence ( 40 to $60 \mathrm{ft}$ [12 to $18 \mathrm{~m}$ ) of low-permeability mudstones that separate the middle and lower sandstone units of the Burro Canyon Formation. The lower sandstone unit has a 
low yield and low velocity. Additional discussion of ground water occurrence and hydraulic properties of the Burro Canyon Formation are presented in Sections 3.2.3 and 3.2.4.

Vertical recharge to and discharge from the Burro Canyon Formation sandstone units are restricted because the low-permeability interbedded claystone and siltstone strata impede infiltration into the water-bearing units. The source of recharge to the uppermost aquifer is northeast of the site, where the sandstone beds outcrop along the east limb of the Disappointment syncline, intercepting tributaries to the Nicholas Wash drainage system. Ground water then flows to the south-southeast and eventually dissipates (discharges) into the surrounding geologic strata south of the Burro Canyon disposal site.

Background ground water quality in each hydrostratigraphic unit within the Burro Canyon Formation was determined from monitoring ground water in wells completed in each unit. In general, ground water pH is fairly neutral, and TDS concentrations tend to decrease with depth; TDS concentrations range from 556 to $973 \mathrm{mg} / \mathrm{L}$ in the upper sandstone, 422 to $696 \mathrm{mg} / \mathrm{L}$ in the middle sandstone, and 256 to $485 \mathrm{mg} / \mathrm{L}$ in the lower sandstone. The only naturally occurring hazardous constituents exceeding the proposed EPA MCLs are selenium and Ra-226 and -228 in the upper sandstone unit and Ra-226 and -228 in the middle sandstone unit. These exceedances have occurred in one or more wells in 1991 and 1992.

Mudstones and claystones of the Burro Canyon Formation are very impermeable to the transmission of ground water and will provide an effective barrier to leachate that could seep from the disposal cell. However, if leachate seeps into the Burro Canyon Formation, the upward hydraulic gradients in the middle and lower sandstone units will prohibit further contaminant migration for up to 1000 years to the extent reasonably achievable and, in any case, for at least 200 years as required in 40 CFR Part 192.

No known registered wells or private wells in the upper sandstone unit of the Burro Canyon Formation are actively used within a 2-mi $(3-\mathrm{km})$ radius of the Burro Canyon disposal site. 


\subsection{GROUND WATER INVESTIGATIONS}

\subsection{PROCESSING SITE}

\subsubsection{Previous investigations}

Site-specific studies that addressed ground water at the Slick Rock NC and UC processing sites were initiated in 1981 when an engineering assessment was conducted by Ford, Bacon \& Davis Utah Inc. (FBDU, 1981). In November 1984 the DOE initiated a reconnaissance investigation of the Slick Rock NC and UC processing sites. Initial hydrogeologic characterization efforts at the processing sites continued through 1986. These investigations included the installation of six shallow monitor wells in the Dolores River alluvium, four deep monitor wells in the Navajo Sandstone, nine auger borings to the top of bedrock, and three test pits. From this limited hydrogeological characterization it appeared that 1) the Navajo Sandstone was confined by the Entrada Formation and 2) an upward potentiometric gradient existed from the Navajo Sandstone in the Entrada Formation.

Additional site characterization at the UC site continued during 1987. Related field activities included excavating 22 test pits, conducting surface geophysics, drilling 10 borings, and packer testing 2 boreholes in the Entrada Formation. In November 1988 the DOE reviewed site data gathered to assess the final design for ground water compliance and to prepare the final remedial action plan (RAP). Borings were drilled, test pits were excavated, and monitoring wells and lysimeters were installed. Sediment, tailings, surface water, ground water, and lysimeter pore fluid samples were collected at the NC and UC processing sites and analyzed to characterize existing conditions. Lysimeter pore fluid samples were analyzed to characterize the tailings source term. Data produced from some of these field activities suggested that the Entrada Formation may not be laterally extensive across the site and may not completely separate the Dolores River alluvium from the Navajo Sandstone, as was previously thought.

The DOE drilled one borehole and installed three monitor wells in the Entrada Formation in 1989. Near-surface ground water was encountered in these monitor wells. Additional drilling in the Entrada Formation indicated the presence of buried paleochannels incised by the ancestral Dolores River. In August 1989 the DOE completed a seismic refraction survey across the UC processing site. Paleochannels and river terraces buried by more recent deposits were verified as a result of the seismic refraction survey.

To more accurately define these subsurface features, the DOE initiated a final site characterization drilling program. Ten monitor wells and twelve exploratory boreholes were installed in September 1989. The drilling program identified 1) the locations, dimensions, and gradients of paleochannels; 2) numerous terraces associated with the incision of the Dolores River; 3) the presence of nearsurface ground water in the Entrada Formation and the Navajo Sandstone across 
parts of the UC processing site; and 4) the susceptibility of the Navajo Sandstone aquifer to contamination, caused by localized erosion of the Entrada Formation confining beds. As a result, it was concluded that the Entrada Formation was not a laterally extensive confining unit as originally thought. Additional information regarding ground water occurrence and hydraulic properties is provided in Sections 3.1.3 and 3.1.4, respectively.

The locations of monitor wells at the UC and NC processing sites are shown on Figure 3.1. Monitor well construction information is provided in Tables 3.1 and 3.2 of Appendix A for the NC and UC processing sites, respectively. Lithologic logs and construction information for all DOE monitor wells are provided in Appendix B. In the following discussions, all reported depths are measured from ground surface.

Ground water elevations were measured and water table maps constructed to determine the direction of ground water flow and hydraulic gradients. Slug tests were performed in the shallow alluvial material and in the Navajo Sandstone to estimate hydraulic conductivity and transmissivity. Ground water samples collected from monitor wells were analyzed to determine ground water quality and to establish the nature and estimate the extent of contamination caused by uranium processing activities. The frequency and duration of sample collection are functions of when the monitor wells were installed, their proximity to the processing sites, and water quality data.

\subsubsection{Geology and hydrostratigraphy}

The UC and NC sites are located approximately $1 \mathrm{mi}(2 \mathrm{~km})$ from each other, along the banks of the meandering Dolores River, as shown in Figure 3.1. Both sites are within the deeply entrenched Dolores River valley at elevations of approximately $5500 \mathrm{ft}(1700 \mathrm{~m})$ above mean sea level (MSL). The sites are located on gently sloping terrace surfaces dissected by small stream channels and gullies. Bedrock ridges and cliffs surrounding the river reach $6500 \mathrm{ft}$ $(2000 \mathrm{~m})$ above MSL. The existing tailings piles are within the modern floodplain of the Dolores River. In their present locations, both piles are subject to potential tailings dispersal caused by flooding. Contaminants continue to leach into the underlying Dolores River alluvial ground water.

The Jurassic Summerville Formation crops out as canyon walls of the alluvial terraces surrounding the Dolores River floodplain, as shown in Figure 3.2. The Summerville consists of eroded layers of interbedded reddish-brown mudstones and siltstones, and some fine-grained sandstones, limestone, and shale; it is not considered to be a hydrostratigraphic unit that directly affects the UC or NC processing sites. The Dolores River meanders around these terraces.

The uppermost aquifer consists of Dolores River alluvium underlain by Entrada Formation (Slick Rock and Dewey Bridge Members) and Navajo Sandstone. A geologic cross section transecting both the UC and NC processing sites is provided in Figure 3.2. These three units range from unconfined to confined, 


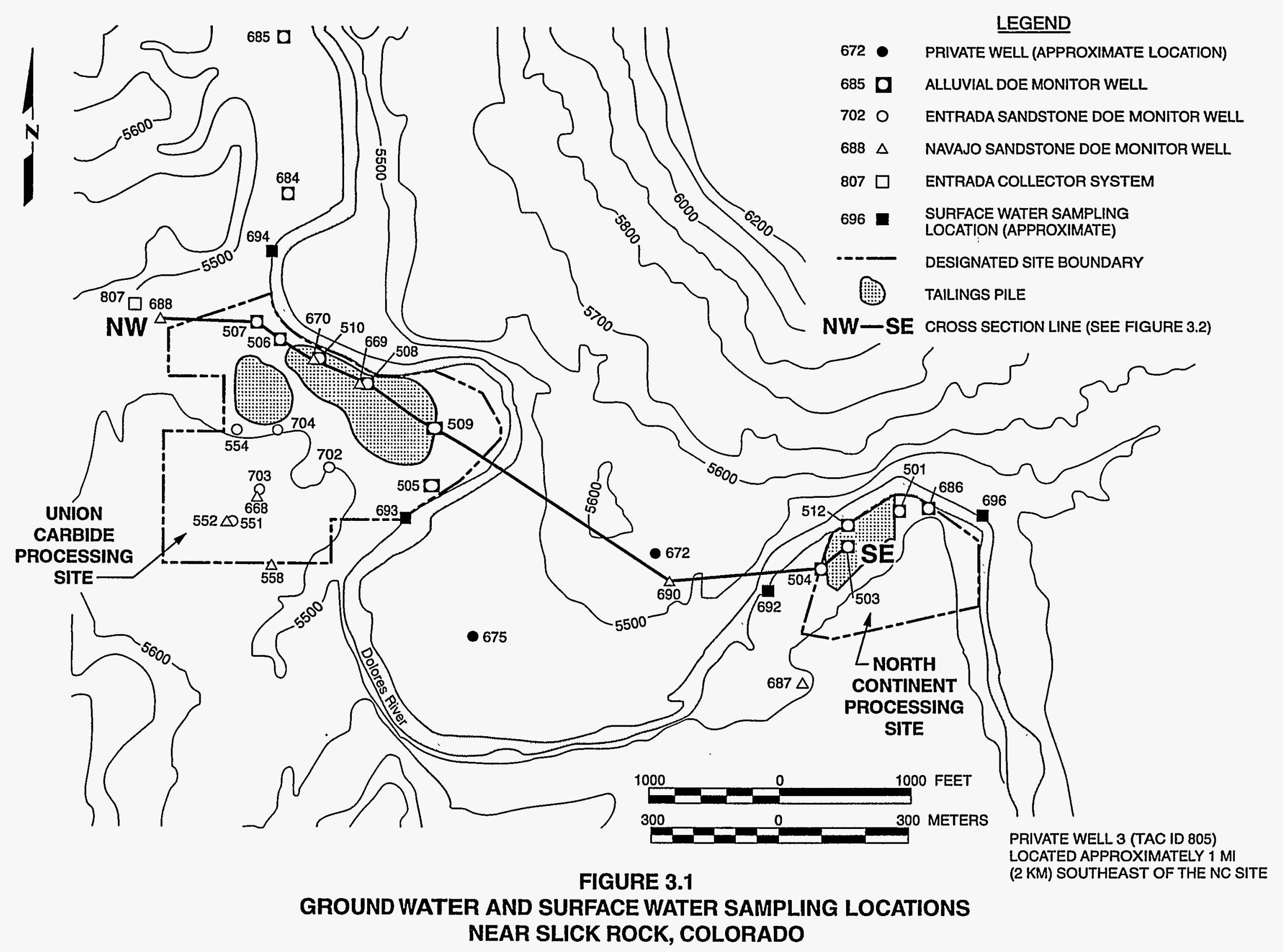




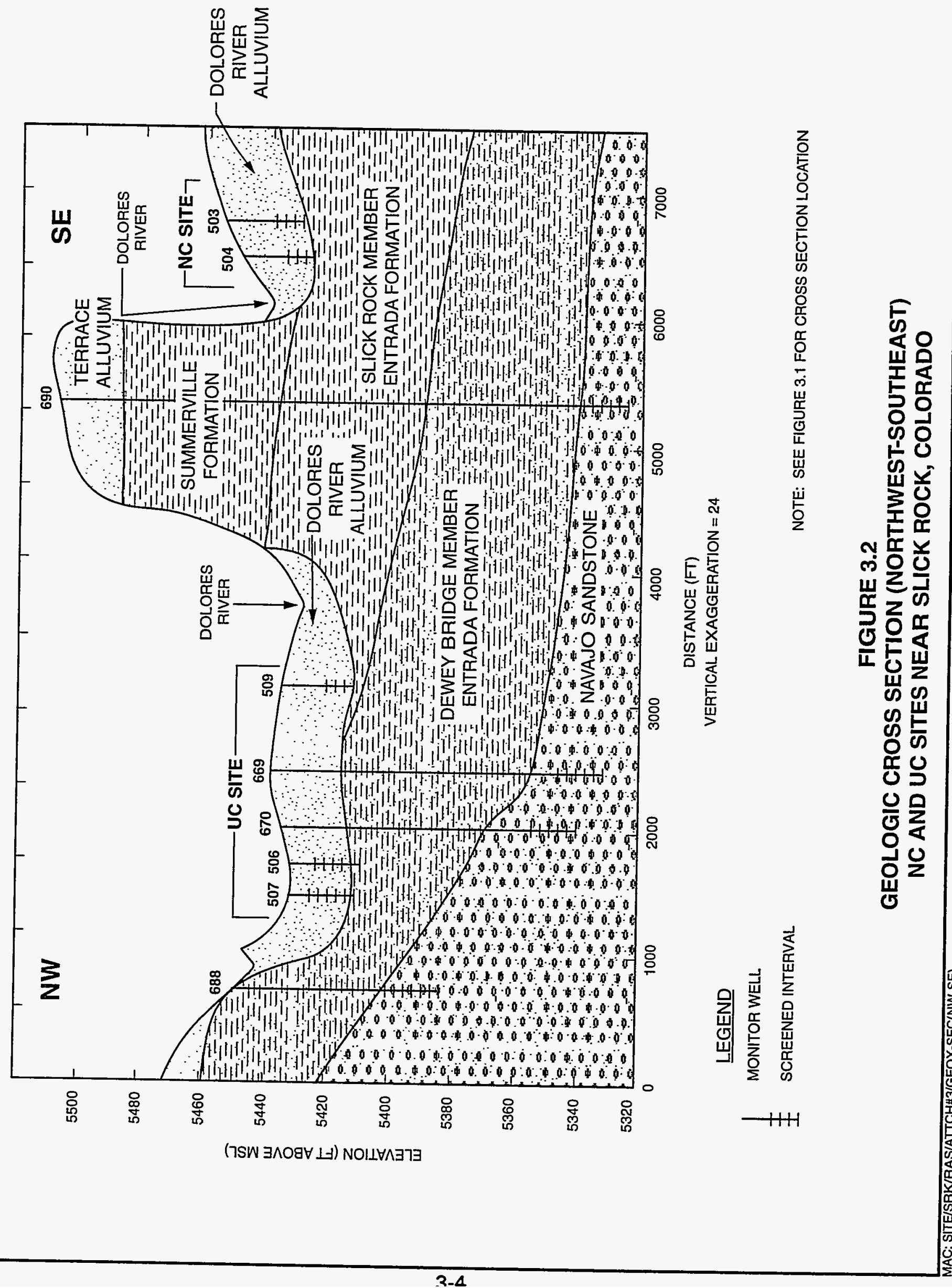


have variable permeabilities, and may be hydraulically connected locally, as discussed in Sections 3.1.3 and 3.1.4.

The Dolores River alluvium is composed of widespread unconsolidated clayey sands, sandy gravels, and cobbles from the ground surface to an approximate depth of $20 \mathrm{ft}(6 \mathrm{~m})$ at both the UC and NC sites. The modern Dolores River channel has diverted the alluvium into discrete lenticular bodies that vary between 250 to $600 \mathrm{ft}(80$ to $180 \mathrm{~m}$ ) in width and 1000 to $4000 \mathrm{ft}$ (300 to $1200 \mathrm{~m}$ ) in length. Quaternary alluvium materials also cap the tops of terraces surrounding the Dolores River floodplain.

The Jurassic Entrada Formation underlies the alluvium in the Dolores River floodplain and underlies the Summerville Formation in terraced areas adjacent to the floodplain. Two members of the Entrada Formation are present: the Slick Rock Member and the Dewey Bridge Member, which dip toward the northeast. The Slick Rock Member underlies the Summerville Formation and alluvial deposits at the NC processing site and pinches out under the UC processing site. The Slick Rock Member is composed of eroded light brown, fine-grained sand that is generally not well cemented and is therefore easily eroded.

The Dewey Bridge Member of the Entrada Formation underlies the Slick Rock Member at the NC processing site. At the UC site, where the Slick Rock Member is absent, the Dewey Bridge Member directly underlies Dolores River alluvium. The top of the Dewey Bridge Member ranges from 20 to $38 \mathrm{ft}(6$ to $12 \mathrm{~m}$ ) thick in the Slick Rock area (Shawe et al., 1968). The Dewey Bridge Member is more impermeable than the Slick Rock Member, consisting of reddish-brown, clayey siltstone, very fine-grained sandstone, and shale. The tops of the Dewey Bridge and Slick Rock Members of the Entrada Formation were encountered beneath the alluvial deposits to depths ranging from 1 to $88 \mathrm{ft}(0$ to $27 \mathrm{~m})$.

The top of the Navajo Sandstone underlies the Entrada Formation throughout the Slick Rock area at depths ranging from 53 to $173 \mathrm{ft}(16$ to $53 \mathrm{~m})$ below land surface. The formation is composed of light-brown to reddish-brown, fine-grained sandstone. The bottom of the Navajo Sandstone was not encountered in any of the DOE borings; therefore, the thickness of the Navajo Sandstone has not been determined directly in the area of the Slick Rock processing sites. However, the U.S. Geological Survey (USGS) reports the Navajo Formation ranges from 0 to $420 \mathrm{ft}(130 \mathrm{~m})$ thick in the Slick Rock area (Shawe et al., 1968).

\subsubsection{Occurrence of ground water}

Ground water conditions at the Slick Rock processing sites depend highly on local structural, stratigraphic, and topographic features. Canyon cutting, tectonic fracturing, and discontinuities between the geologic formations are believed to have caused distinct stratigraphic units to become hydraulically connected. 
The uppermost aquifer at the NC and UC sites consists of three

hydrostratigraphic units: 1) Quaternary alluvium associated with the Dolores River floodplain deposits, 2) the Slick Rock and Dewey Bridge Members of the Entrada Formation, and 3) the Navajo Sandstone. Ground water flow is unconfined in the alluvium and is expected to be semiconfined to confined in the underlying Entrada Formation and semiconfined to confined in the Navajo Sandstone Formation. These three formations appear to be hydraulically connected, based on lithologic data and ground water levels. Static ground water levels at the Slick Rock processing sites are provided in Table 3.3 of Appendix A. Ground water elevations in the alluvium, the Entrada Formation, and the Navajo Sandstone have remained relatively constant and have not shown seasonal fluctuations for over 4 years.

\section{Ground water conditions in the Dolores River alluvium}

The occurrence of ground water in the alluvium at the processing sites is limited to the recent channels and paleochiannels of the Dolores River. Water table elevations measured in the Dolores River alluvium underlying the Slick Rock processing sites are shown on Figure 3.3 for February 1994. The ground water hydrographs presented in Figures 3.4 and 3.5 show that water level elevations in the alluvium range from approximately 5420 to $5431 \mathrm{ft}(1650$ to $1655 \mathrm{~m})$ at the UC site and from 5437 to $5442 \mathrm{ft}$ (1657 to $1659 \mathrm{~m}$ ) at the NC site. The depth to ground water at both processing sites ranges from 5 to $20 \mathrm{ft}(2$ to $6 \mathrm{~m}$ ) in wells screened in the alluvium. The unconfined ground water level in the alluvium under the tailings piles is approximately the same as the surface water levels of the Dolores River. The water table contour map indicates that ground water in the alluvium flows toward the Dolores River. Ground water flows generally to the north in the alluvium. The hydraulic gradient ranges from 0.003 at the NC site to 0.008 at the UC site. The alluvial aquifer is recharged by seepage from the Dolores River upstream of the NC site and by precipitation. Ground water discharges from the alluvium into the Dolores River downgradient of the UC site.

\section{Ground water conditions in the Entrada Formation}

In UC processing site monitor wells screened in the Entrada Formation, the depth to ground water is approximately 27 to $48 \mathrm{ft}(8.2$ to $15 \mathrm{~m})$. Ground water elevations in the Entrada Formation are shown in Figure 3.6 for February 1994. No monitor wells are screened in the Entrada Formation at the NC site; therefore, the information available for ground water movement in the Entrada Formation is limited. The potentiometric surface map for the UC site presented in Figure 3.6 suggests that ground water movement is generally to the east in the Entrada Formation; however, this representation may be biased by a limited number of monitor wells placed across a relatively small areal extent of the UC site. A ground water hydrograph for wells screened in the Entrada Formation (Figure 3.7) shows that water levels have historically remained relatively constant. All Entrada wells are screened in the Dewey Bridge Member. Ground water is expected to be semiconfined when medium- to coarse-grained 


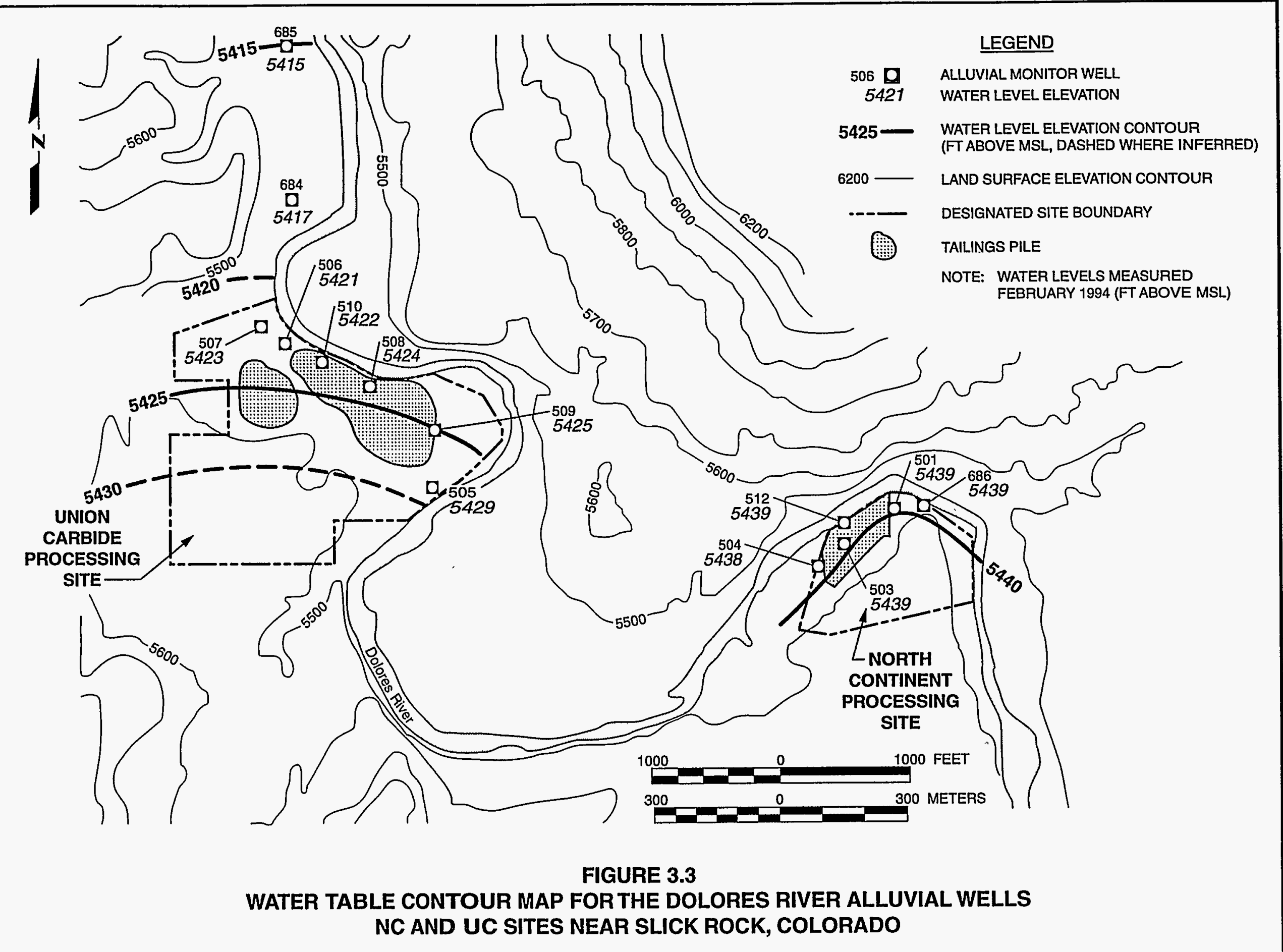




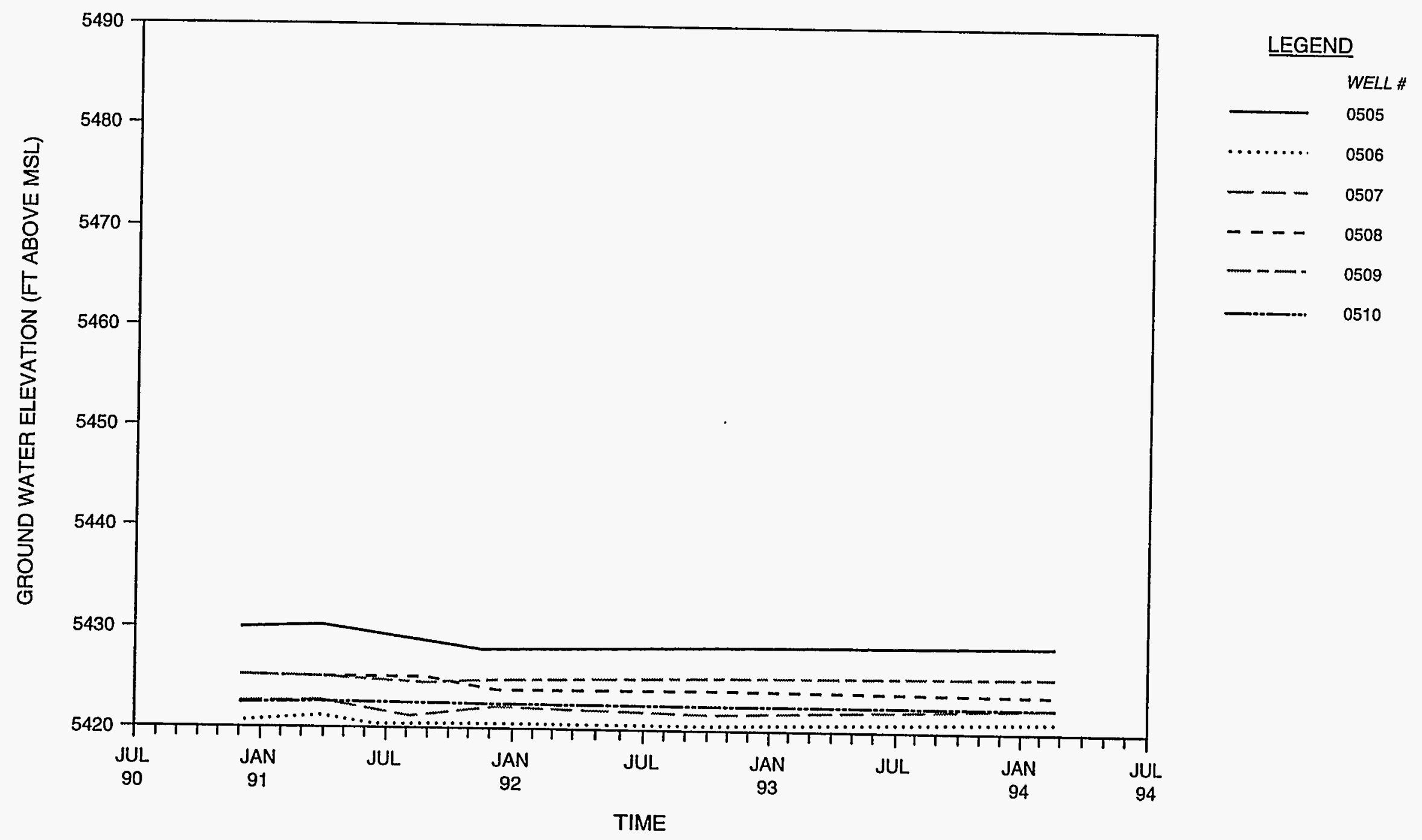

FIGURE 3.4

GROUND WATER HYDROGRAPH OF THE DOLORES RIVER ALLUVIUM

UC PROCESSING SITE NEAR SLICK ROCK, COLORADO 


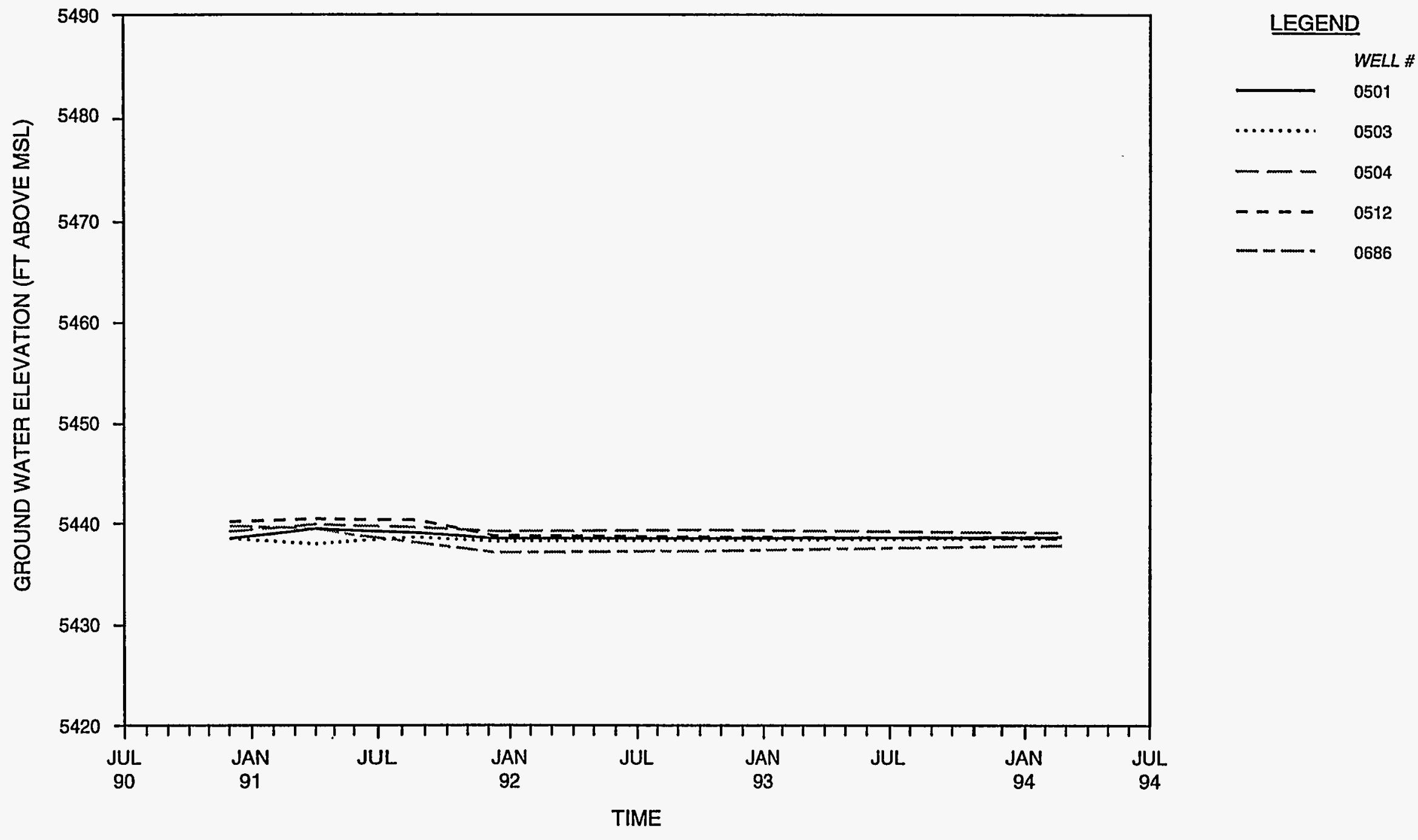

FIGURE 3.5

GROUND WATER HYDROGRAPH OF THE DOLORES RIVER ALLUVIUM NC PROCESSING SITE NEAR SLICK ROCK, COLORADO 


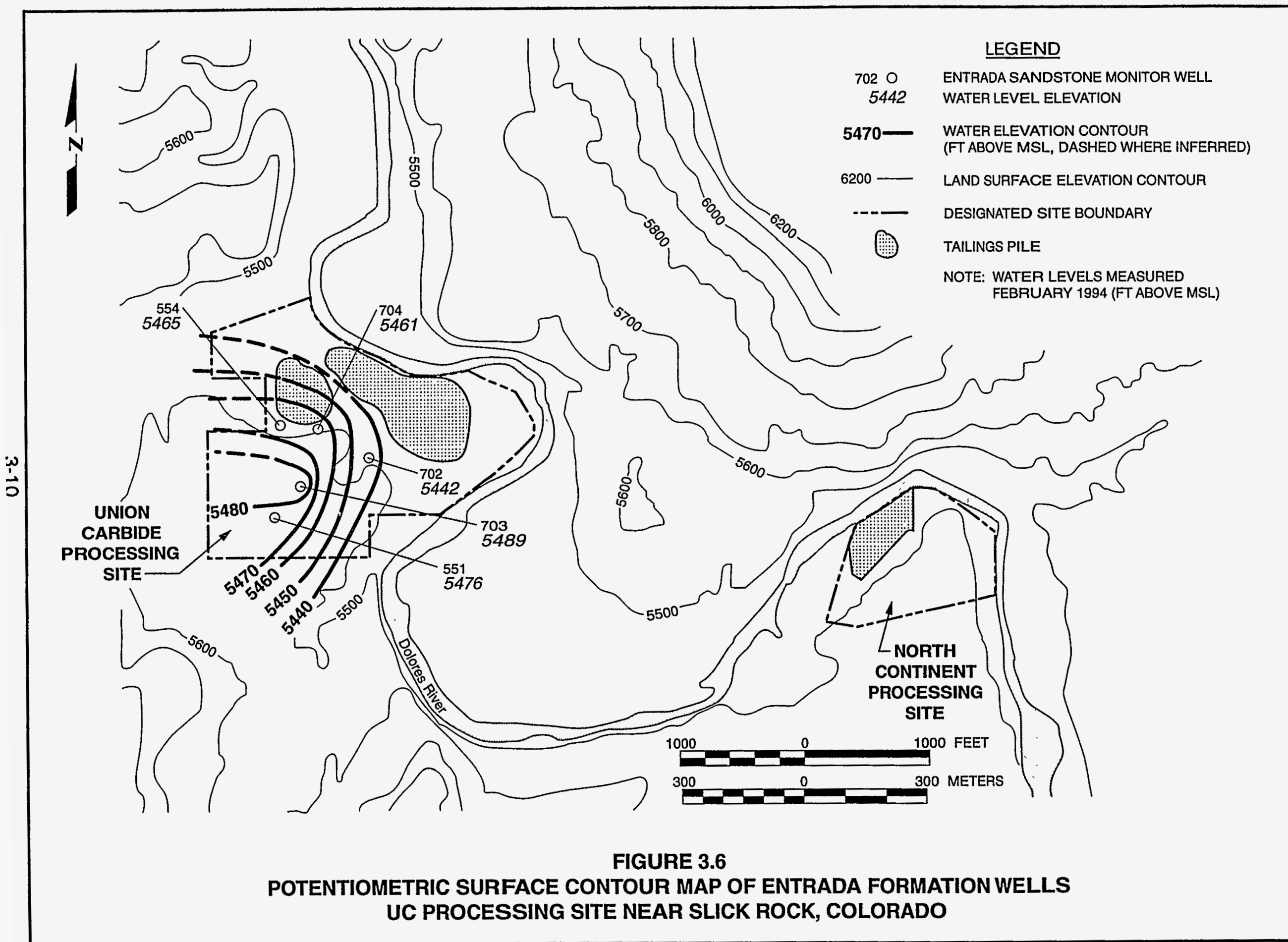




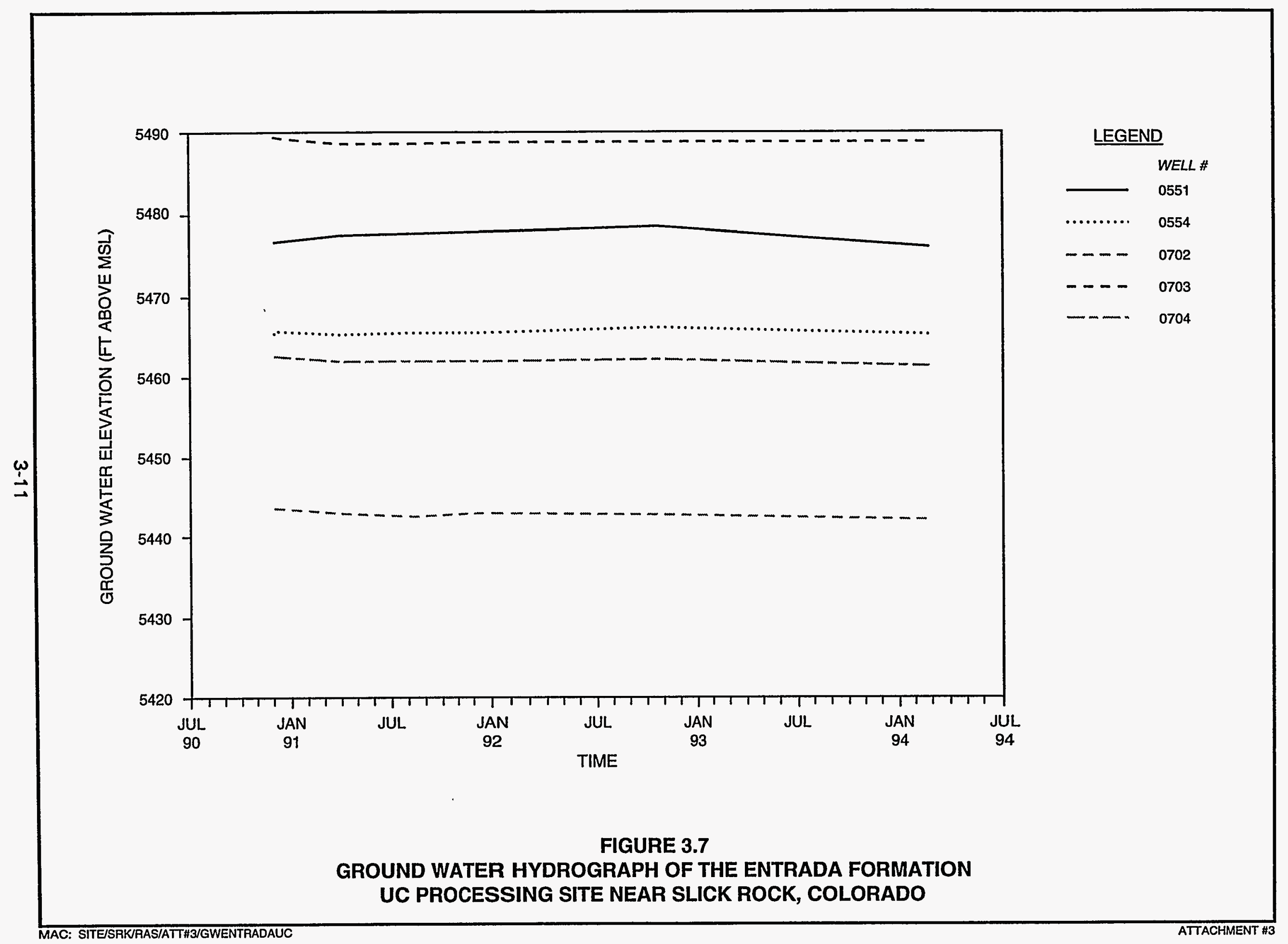


sediments are interbedded with clayey siltstones and shales; confined conditions are expected when only low-permeability siltstones and shales exist. The Entrada Formation is capable of producing a source of water, as evidenced by a gravity flow collector system tapping the Entrada Formation on a canyon wall west of the UC processing site. Additional information is provided in Section 3.1.9. Lithologic logs (Appendix B) for some monitor wells in the southwest portion of the UC site $(551,552,554,556,558,559,668,702$, and 704) show a layer of sandy gravel, approximately $25 \mathrm{ft}(8 \mathrm{~m})$ thick, that has cut through the Slick Rock Member and eroded portions of the Dewey Bridge Member of the Entrada Formation.

\section{Ground water conditions in the Navajo Sandstone Formation}

In UC and NC monitor wells screened in the Navajo Sandstone, the depths to ground water vary from approximately 0 to $58 \mathrm{ft}(18 \mathrm{~m})$. Ground water elevations in the Navajo Sandstone Formation are contoured in Figure 3.8 for February 1994 and are plotted versus time in the hydrograph in Figure 3.9. The direction of ground water flow is generally to the north at both processing sites. The variability in the directions of the ground water contours is expected to be a result of differences in subsurface material permeability and a limited number of monitor wells. Ground water is expected to be semiconfined to confined in the Navajo Sandstone. The relative amount of hydraulic connection between the Navajo Sandstone and the Entrada Formation depends on the permeability of the Navajo Sandstone and the overlying materials of the Entrada Formation, as well as on the variations in the contacts between the formations. Adjacent to the Dolores River, static ground water elevations are approximately 10 to $15 \mathrm{ft}$ ( 3 to $5 \mathrm{~m}$ ) higher in the Navajo Sandstone monitor wells $(669$ and 670) than in those screened in the Dolores River alluvium (505 to 510 ). These static water levels are indicative of an upward vertical gradient (confined conditions) in the Navajo Sandstone near the Dolores River.

Site characterization activities conducted in September 1989 indicated the presence of paleochannels at the UC site. Lithologic data suggest that paleochannels have eroded into the Entrada Formation and the Navajo Sandstone, contributing up to $50 \mathrm{ft}(15 \mathrm{~m})$ of highly permeable gravel. Because the Entrada Formation has been partially eroded away, the Navajo Sandstone may be semiconfined under portions of the UC site.

\subsubsection{Hydraulic characteristics}

Hydraulic characteristics were estimated in 1986 and 1987. Slug tests were conducted in the shallow alluvium and in the Navajo Sandstone at the NC and UC processing sites. The middle hydrostratigraphic unit, the Entrada Formation, was not tested.

\section{Dolores River alluvium}

Hydraulic conductivities estimated for the Dolores River alluvium and the Navajo Sandstone at the Slick Rock, Colorado, processing sites are shown in Table 3.4 


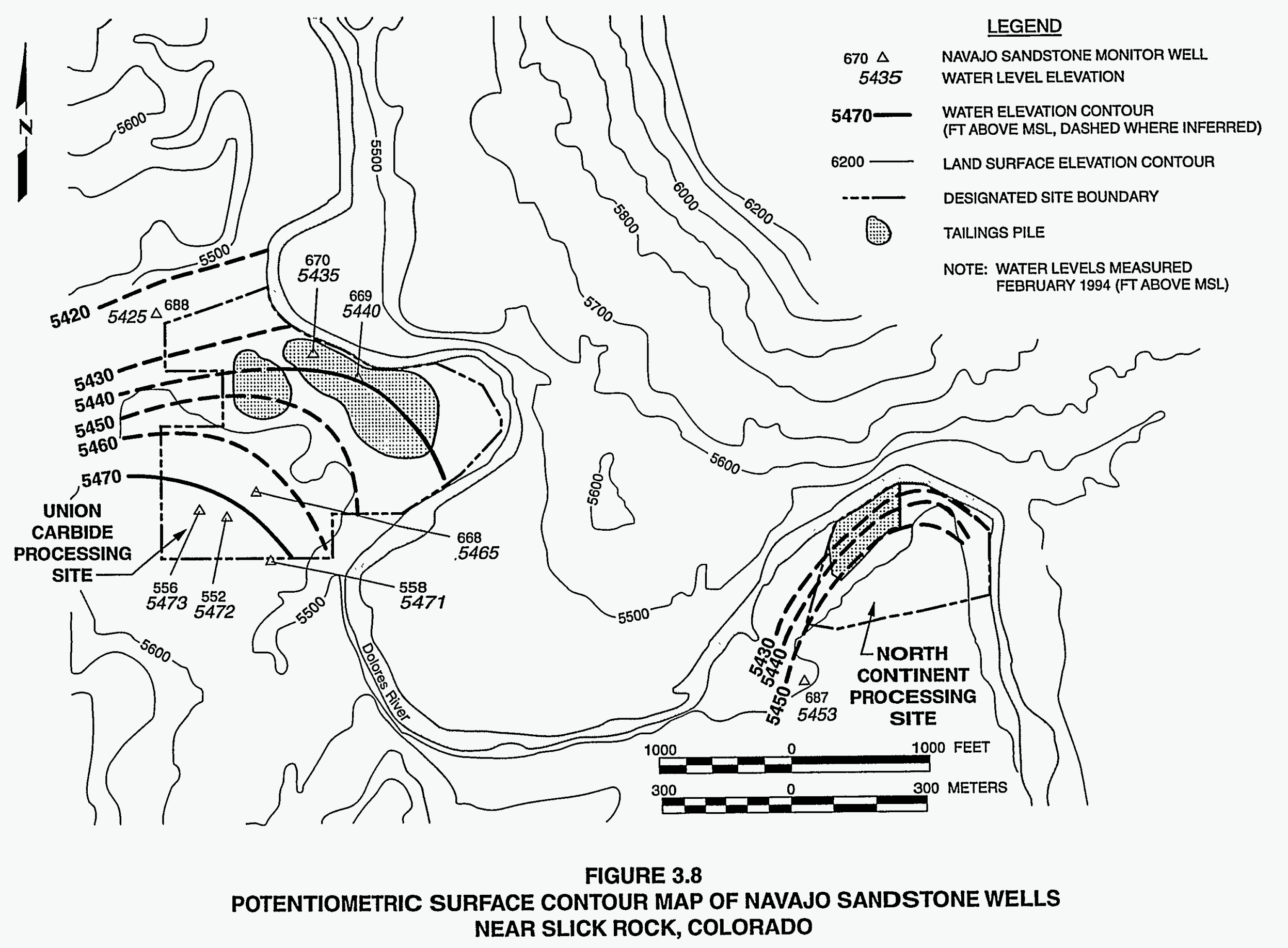




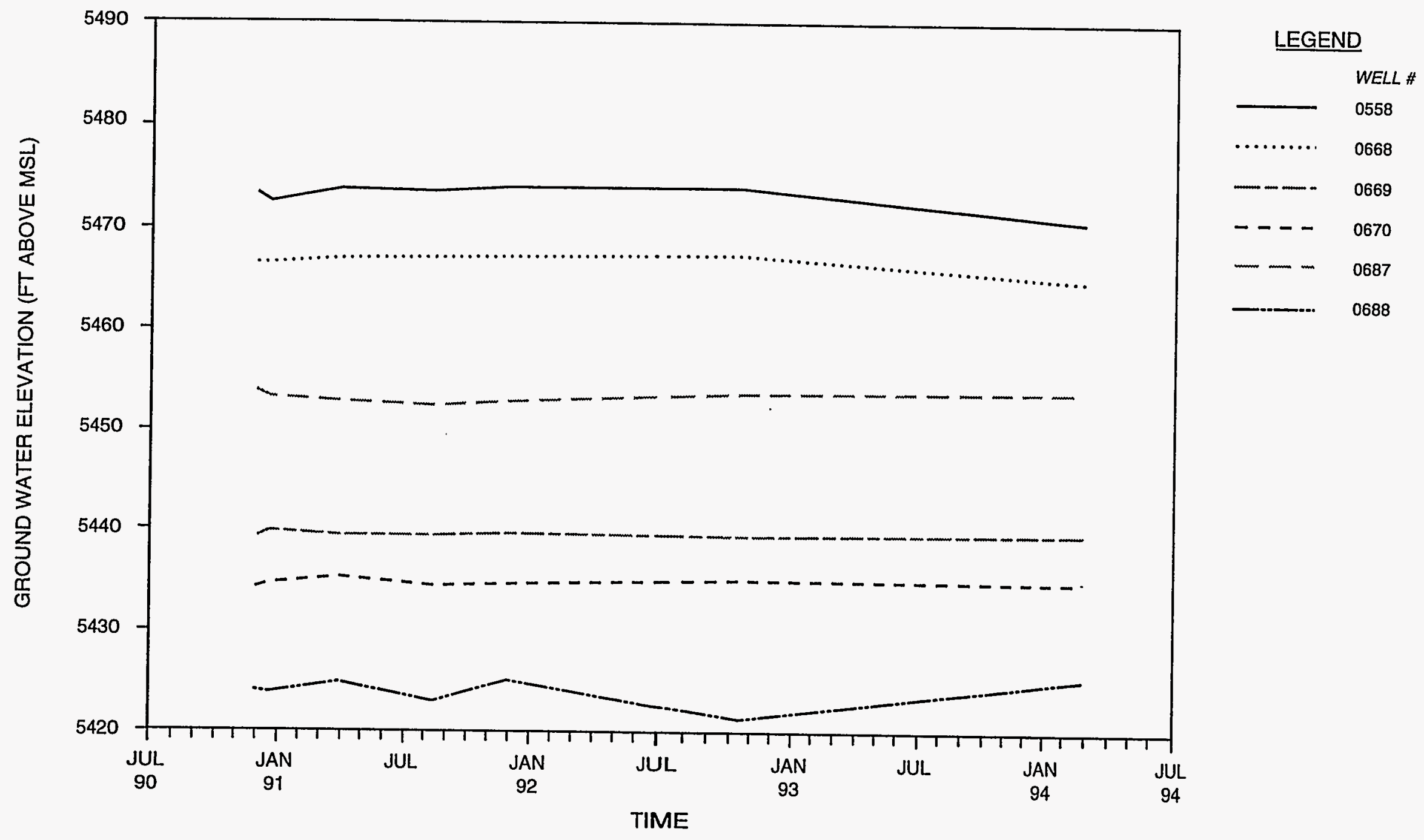

FIGURE 3.9

GROUND WATER HYDROGRAPH OF THE NAVAJO SANDSTONE

NC AND UC SITES NEAR SLICK ROCK, COLORADO 
of Appendix A. The hydraulic conductivity of the alluvium ranges from 6 to $50 \mathrm{ft} /$ day $\left(2 \times 10^{-3}\right.$ to $20 \times 10^{-3}$ centimeters per second $\left.[\mathrm{cm} / \mathrm{s}]\right)$. At the NC site, the geometric mean hydraulic conductivity is $23 \mathrm{ft} /$ day $\left(8.1 \times 10^{-3} \mathrm{~cm} / \mathrm{s}\right)$. At the UC site, the geometric mean hydraulic conductivity is $14 \mathrm{ft} /$ day $\left(4.9 \times 10^{-3} \mathrm{~cm} / \mathrm{s}\right)$.

Darcy's Law was used to calculate the average linear ground water velocity in the alluvium at each tailings site, and the results are summarized in Table 3.5 of Appendix A. The average linear ground water velocity in the alluvium at the NC site was estimated to be $100 \mathrm{ft} /$ year $\left(1 \times 10^{-4} \mathrm{~cm} / \mathrm{s}\right)$, based on an average hydraulic conductivity of $23 \mathrm{ft} / \mathrm{day}\left(8.1 \times 10^{-3} \mathrm{~cm} / \mathrm{s}\right)$, a hydraulic gradient of 0.003 , and an effective porosity of 0.25 for sand and gravel (Freeze and Cherry, 1979). The average linear ground water velocity in the alluvium at the UC site was estimated to be $160 \mathrm{ft} /$ year $\left(1.5 \times 10^{-4} \mathrm{~cm} / \mathrm{s}\right)$, based on an average hydraulic conductivity of $14 \mathrm{ft} / \mathrm{day}\left(4.9 \times 10^{-3} \mathrm{~cm} / \mathrm{s}\right)$, a hydraulic gradient of 0.008 , and an effective porosity of 0.25 .

\section{Navajo Sandstone Formation}

The hydraulic conductivity of the Navajo Sandstone is considerably less than that of the Dolores River alluvium. In the Navajo Sandstone, the hydraulic conductivity was estimated to range from $6.6 \times 10^{-3}$ to $1.9 \times 10^{-1} \mathrm{ft} / \mathrm{day}$ $\left(2.3 \times 10^{-6}\right.$ to $\left.67 \times 10^{-6} \mathrm{~cm} / \mathrm{s}\right)$ and averages $2.4 \times 10^{-2} \mathrm{ft} / \mathrm{day}$ $\left(8.5 \times 10^{-6} \mathrm{~cm} / \mathrm{s}\right)$.

The average linear ground water velocity of the Navajo Sandstone is also considerably lower than that of the alluvium. The calculated average linear ground water velocity in the Navajo Sandstone is $5.8 \times 10^{-1} \mathrm{ft} /$ year $\left(5.6 \times 10^{-7} \mathrm{~cm} / \mathrm{s}\right)$, based on an average hydraulic conductivity of $2.4 \times 10^{-2} \mathrm{ft} / \mathrm{day}\left(8.5 \times 10^{-6} \mathrm{~cm} / \mathrm{s}\right)$ under a hydraulic gradient of 0.02 and an estimated effective porosity of 0.30 (Cooley et al., 1969).

\subsubsection{Background ground water quality}

Site characterization activities conducted to date at the Slick Rock processing sites were intended to provide sufficient preliminary site characterization information to design and implement a surface remediation plan for relocating the residual radioactive materials (RRM) to the Burro Canyon disposal site. Background ground water quality is defined as the quality of ground water that would be expected at the site if uranium processing activities had not occurred. Water samples were collected from monitor wells located in areas hydraulically upgradient and cross gradient from the sites for chemical analysis. For the NC site, background ground water quality has been determined for the Dolores River alluvium and the Navajo Sandstone. No monitor wells were screened in the Entrada Formation at the NC site. At the UC site, background ground water quality has been determined for each of the three hydrostratigraphic units: Dolores River alluvium, Entrada Formation, and Navajo Sandstone. Detailed information is provided in Appendix $\mathrm{C}$ to of this document, Calculation No. SRK-05-93-14-10-00. 
Background water quality was characterized by analyzing constituents listed in Table 8.1 of the Technical Approach Document (TAD) (DOE, 1989). For characterization purposes, background water quality is described by the average concentration in the sample data and a statistical maximum. The procedures for calculating average and statistical maximum concentrations are discussed in Statistical Analysis of Ground-Water Monitoring Data at RCRA Facilities-Interim Final Guidance (EPA, 1989) and are described in the TAD (DOE, 1989). Average concentrations of hazardous constituents are represented statistically by a mean or median, depending on the proportion of nondetects, the distribution of the water quality data, and the number of samples available. The following guidelines apply:

- If the coefficient of variation of the data is greater than one, the distribution is assumed to be lognormal and the geometric mean is reported.

- If the coefficient of variation of the data is less than one, the distribution is assumed to be normal and the arithmetic mean is reported.

- If more than 15 percent of the data are below detection, the median is reported.

- If fewer than four samples are available, the median is reported.

Distribution types are unknown if fewer than four samples are reported.

The statistical maximum is the upper limit of the 98 percent confidence interval for the true average concentration assuming normal or lognormal distributions. A nonparametric upper confidence interval is used if more than 15 percent of the data are below detection. If fewer than four samples are reported, the maximum observed concentration is chosen as a statistical maximum. When the majority of data are below detection, the reported statistical maximum may be the detection limit divided by 2, as computed by the Software Program for Environmental Analysis and Reporting (SPEAR) system (DOE, 1992). When the statistical values calculated are below the actual laboratory detection limits, the laboratory detection limits reported in Table 8.1 of the TAD (DOE, 1989) are applied.

\section{Background ground water quality in the alluvium-North Continent site}

Two background monitor wells are screened and filter packed in the Dolores River alluvium at the NC site. These monitor wells are identified as 501 and 686 (see Figure 3.11. Ground water quality data by parameter are provided in Table 3.5 of Appendix $\mathbf{A}$ and ground water quality statistics are provided in Table 3.6 of Appendix A.

Review of the background ground water analysis reveals the $\mathrm{pH}$ of ground water in the Dolores River alluvium at the NC site ranges from 6.9 to 7.7 and averages 7.2. TDS concentrations measured in background monitor wells at the NC site range from $622 \mathrm{mg} / \mathrm{L}$ to $991 \mathrm{mg} / \mathrm{L}$. Baekground groumd water qualitity in the 
alluvial materials is characterized as a calcium-sodium sulfate type at both the NC and UC sites.

Table 3.7 of Appendix A summarizes regulated constituents, with and without MCLs, from NC background monitor well samples. MCLs of some regulated constituents have been exceeded in ground water samples collected from the NC background monitor wells screened in the Dolores River alluvium. These exceedances are shown in Table 3.8 of Appendix $A$ and are discussed below.

Molybdenum-Molybdenum concentrations slightly exceeded the $\mathrm{MCL}$ $10.1 \mathrm{mg} / \mathrm{L}$ ) once (July 1986) in a sample collected from monitor well 501 and twice (July 1986 and February 1988) in ground water samples collected from monitor well 686. The statistical maximum for molybdenum in ground water samples collected from the NC alluvial background monitor wells is $0.12 \mathrm{mg} / \mathrm{L}$ which slightly exceeds the MCL for molybdenum.

Uranium-Uranium concentrations have exceeded the $M C L(0.044 \mathrm{mg} / \mathrm{L})$ on three separate occasions in a one-year time frame (April 1987 to April 1988) in ground water samples collected from monitor well 686. Furthermore, the statistical maximum for uranium is 0.045 , which slightly exceeds the uranium MCL.

Ra-226 and $-228-R a-226$ and -228 activities exceeded the MCL 15.0 picocuries per liter [pCi/L]) once in a sample collected from monitor well 501 in March 1991. The statistical maximum for Ra-226 and -228 equals this one-time exceedance $(7.48 \mathrm{pCi} / \mathrm{L})$ and exceeds the $5.0 \mathrm{pCi} / \mathrm{L} \mathrm{MCL}$ for Ra-226 and -228 . However, this radium exceedance appears suspect because the detected activity occurs completely in Ra-228 and because, aside from this one-time occurrence, $\mathrm{Ra}-228$ has never exceeded $1.5 \mathrm{pCi} / \mathrm{L}$ at this location. Therefore, this exceedance may be the result of a laboratory analysis error rather than a true measurement of the Ra-228 activity.

\section{Background ground water quality in the alluvium - Union Carbide site}

Background monitor well 505 has been used to characterize ground water quality in the Dolores River alluvium at the UC site. Ground water quality data by parameter are provided in Table 3.5 of Appendix $A$ and ground water quality statistics are provided in Table 3.9 of Appendix A.

Based on the results of historical water quality monitoring at this location, the background pH ranges from 6.9 to 7.3 at the UC site. TDS concentrations measured in this background monitor well range from $830 \mathrm{mg} / \mathrm{L}$ to $1180 \mathrm{mg} / \mathrm{L}$.

Table 3.10 of Appendix A summarizes regulated constituents, with and without MCLs, from UC background monitor well samples. MCLs have been exceeded for the following constituents in ground water samples collected from the UC alluvial background monitor well as shown in Table 3.8 of Appendix A. 
Molybdenum-Molybdenum either equaled or slightly exceeded its $\mathrm{MCL}$ $(0.1 \mathrm{mg} / \mathrm{L})$ in samples collected from monitor well 505 in July 1986 and February 1988. The statistical maximum for molybdenum $(0.11 \mathrm{mg} / \mathrm{L})$ in UC background alluvial monitor wells slightly exceeds the MCL.

Chromium-Chromium exceeded the MCL $(0.05 \mathrm{mg} / \mathrm{L})$ once in a sample collected from monitor well $505(0.07 \mathrm{mg} / \mathrm{L})$ in July 1986. However, this chromium exceedance appears suspect because chromium has not been detected at this sampling location, aside from this one-time occurrence. Therefore, this exceedance may be the result of a sample collection or analysis problem rather than a true measurement of the chromium concentration.

\section{Background ground water quality in the Entrada Formation-Union Carbide site}

Background ground water quality in the Entrada Formation has been characterized by monitoring two wells (551 and 703) at the UC site. Construction information for these two background monitor wells, screened and filter packed in the Entrada Formation, is provided in Table 3.2 of Appendix A. Monitor well locations are shown in Figure 3.1. Ground water quality data by parameter are provided in Table 3.11 of Appendix $A$ and ground water quality statistics are provided in Table 3.12 of Appendix A.

The $\mathrm{pH}$ of ground water in the Entrada Formation is slightly alkaline, ranging from 7.8 to 8.0. TDS concentrations measured in the Entrada Formation background monitor wells range from $147 \mathrm{mg} / \mathrm{L}$ to $1990 \mathrm{mg} / \mathrm{L}$. Background ground water quality of the Entrada Formation is characterized as a calcium bicarbonate to sodium bicarbonate type.

Table 3.13 of Appendix A summarizes regulated constituents with and without MCLs from Entrada Formation background monitor well samples. Two hazardous constituents, Ra-226 and -228 and selenium, have exceeded their respective MCLs in ground water samples collected from the background monitor wells screened in the Entrada Formation, as shown in Table 3.14 of Appendix A.

Ra-226 and $-228-R a-226$ and -228 exceeded their MCLs $(5.0 \mathrm{pCi} / \mathrm{L})$ once (August 1991) in a sample collected from monitor well 703 . However, the statistical maximum for Ra-226 and -228 is below the MCL.

Selenium-Selenium has exceeded its MCL $(0.01 \mathrm{mg} / \mathrm{L})$ twice in four months (December 1990 to March 1991) in ground water samples collected from monitor well 551. The statistical maximum for background ground water quality in the Entrada Formation for seienium $(0.013 \mathrm{mg} / \mathrm{L})$ slightly exceeds the MCL. 
Background ground water quality in the Navajo Sandstone-North Continent site

Background ground water quality in the Navajo Sandstone was characterized by monitoring one well at the NC site (687), shown in Figure 3.1. Ground water quality data by parameter are provided in Table 3.15 of Appendix $A$ and ground water quality statistics are provided in Table 3.16 of Appendix $A$.

The $\mathrm{pH}$ of ground water samples collected from background monitor wells screened in the Navajo Sandstone at the NC site ranges from 7.2 to 7.6. TDS concentrations range from $492 \mathrm{mg} / \mathrm{L}$ to $1530 \mathrm{mg} / \mathrm{L}$. Background ground water quality in the Navajo Sandstone is characterized as a sodium bicarbonate type at the NC site.

Table 3.17 of Appendix A summarizes regulated constituents, with and without MCLs, from Navajo Formation background monitor well samples. MCLs for several hazardous constituents have been equaled or exceeded in ground water samples collected from the background monitor well 687. The MCLs for chromium, molybdenum, Ra-226 and -228 , and uranium have been equaled or exceeded in NC Navajo Sandstone monitor well samples, as shown in Table 3.18 of Appendix A.

Chromium-Chromium was reported to equal the MCL $(0.05 \mathrm{mg} / \mathrm{L}$ ) once (July 1986) in a sample collected from mionitor well 687 at the NC site. However, this chromium exceedance appears suspect because 1) chromium has never been detected in any monitor wells screened in the Navajo Sandstone, aside from this one-time occurrence, and 2) the MCL for chromium also was exceeded in a one-time occurrence in a sample collected from a UC alluvial background monitor well on the same date. Therefore, this exceedance may result from a sample collection or analysis problem rather than from a true measurement of the chromium concentration.

Molybdenum-Molybdenum exceeded the MCL $(0.1 \mathrm{mg} / \mathrm{L})$ in $\mathrm{NC}$ monitor well 687 on one occasion in 1986.

Ra-226 and -228-Ra-226 and -228 activities exceeded the MCL (5.0 pCi/L) in NC background Navajo Sandstone monitor well 687 on one occasion in 1991. The statistical maximum for Ra-226 and -228 activities at the NC site (5.2 $\mathrm{pCi} / \mathrm{L}$ ) slightly exceeds the MCL.

Uranium-Uranium was reported to exceed the MCL in one sample collected from monitor well 687 . However, the statistical maximum for uranium $(0.026 \mathrm{mg} / \mathrm{L})$ at the NC site does not exceed the MCL $(0.044 \mathrm{mg} / \mathrm{L})$.

Background ground water quality in the Navajo Sandstone-Union Carbide site

At the UC site, background ground water quality in the Navajo Sandstone was characterized by monitoring two wells (668 and 558). Monitor well locations are shown in Figure 3.1. Ground water quality data by parameter are provided 
in Table 3.15 of Appendix $A$ and ground water quality statistics are provided in Table 3.19 of Appendix A.

The $\mathrm{pH}$ of ground water measured in background monitor wells screened in the Navajo Sandstone ranges from 7.4 to 8.2, at the UC site. TDS concentrations are generally lower at the UC site than at the NC site, where they range from $229 \mathrm{mg} / \mathrm{L}$ to $1160 \mathrm{mg} / \mathrm{L}$. Background ground water quality in the Navajo Sandstone is characterized as a magnesium bicarbonate type at the UC site.

Table 3.20 of Appendix A summarizes regulated constituents, with and without MCLs, from Navajo Formation background monitor well samples.

Concentrations or activities of molybdenum, Ra-226 and -228 , selenium, and silver measured in UC Navajo Sandstone monitor well samples have also equaled or exceeded the respective MCLs, as shown in Table 3.18 of Appendix A. However, most of these exceedances have since been flagged as suspect in a review of potential anomalies in the historical database.

Molybdenum-Molybdenum exceeded the MCL $(0.1 \mathrm{mg} / \mathrm{L})$ in UC monitor well 668. This is the same sampling round in which a molybdenum exceedance was reported for Navajo Sandstone monitor well 687 at the NC site.

Ra-226 and -228-Ra-226 and -228 activities exceeded the MCL $(5.0 \mathrm{pCi} / \mathrm{L})$ in all of the UC background Navajo Sandstone monitor wells on one or more occasions in 1991. The statistical maximum for Ra-226 and -228 activities at the UC site $(4.0 \mathrm{pCi} / \mathrm{L})$ is less than the $\mathrm{MCL}$.

Selenium-Selenium concentrations exceeded the $M C L(0.01 \mathrm{mg} / \mathrm{L})$ twice in 10 months (December 1991 to October 1992) in ground water samples collected from monitor well 558 (UC site). The statistical maximum for background ground water quality in the Navajo Sandstone $10.025 \mathrm{mg} / \mathrm{L}$ for the UC site) exceeds the MCL for selenium.

Silver-Silver was reported to exceed the MCL in a sample collected from monitor well 668 during the July 1986 sampling round. However, this reported value is suspect because silver has never been detected in any background monitor wells, aside from this one-time occurrence.

\subsubsection{Tailings and milling process characterization}

Contaminated materials cover an estimated 12 acres (4.9 hectares) of the NC site and 55 acres ( 22 hectares) of the UC site. Both processing sites have tailings piles and wind- and waterborne-contaminated areas. In addition, concrete foundations of mill buildings exist at the UC site. The estimated volume of contaminated materials for the NC and UC sites is provided in Table 1.1 of the remedial action selection report. In addition to the contamination in the two processing site areas, four properties off the site (vicinity properties [VP]) were found to be contaminated from uranium milling 
activities. Site-specific information for tailings characterization is provided below for both the NC and UC processing sites.

\section{North Continent processing site}

The original owner of the site was Shattuck Chemical Company. North Continent Mines Inc. acquired the site in 1934. A method of acid leaching was used on ore that averaged 0.28 percent $\mathrm{U}_{3} \mathrm{O}_{8}$ and 3 percent $\mathrm{V}_{2} \mathrm{O}_{5}$. The initial mill capacity was 10 to 15 tons (9000 to 14,000 kilograms [kg]) per day (FBDU, 1977). In 1942 a rotary kiln roaster was installed and the mill converted to a salt roast process with acid leach to recover $\mathrm{V}_{2} \mathrm{O}_{5}, \mathrm{U}_{3} \mathrm{O}_{8}$, and a radium concentrate. Mill capacity was increased to 30 tons $(30,000 \mathrm{~kg})$ per day. Title was passed to several companies, including UC, the present owner, in 1957. An estimated 37,000 tons $\left(34 \times 10^{6} \mathrm{~kg}\right)$ of ore were processed during the mill lifetime, producing the same amount of tailings. Seepage from the NC tailings pile has entered the ground water in the alluvium beneath the site.

All structures were removed after milling operations were discontinued in the early 1960s. When the mill was dismantled, bricks removed from the roaster were buried in the tailings pile. The pile was contoured, covered with 6 inches $(0.2 \mathrm{~m})$ of soil, and vegetated.

Laboratory measurements of water content in tailings samples indicate that much of the tailings are relatively dry sands (see Attachment 1 of this RAP). The NC tailings average residual volumetric moisture content is $\mathbf{5 . 1}$ percent (ranging from 4.6 to 6 percent). Laboratory saturated permeability tests indicate the NC tailings' saturated hydraulic conductivity is $130 \mathrm{ft} /$ day $\left(4.6 \times 10^{-2} \mathrm{~cm} / \mathrm{s}\right)$.

The chemical characteristics of the tailings were evaluated by pore fluid sampling with suction lysimeters. Five lysimeters were placed in the NC tailings materials in November 1990 at the locations shown in Figure 3.1. Samples collected from the lysimeters were screened for the inorganic and radioactive hazardous constituents of concern, listed in Table 1.1 of Appendix A. In some instances, the quantities of tailings pore water collected from the lysimeters were insufficient to conduct all of the analytical laboratory tests. As a result, data for some inorganic and radionuclide parameters (i.e., nitrate, gross alpha, and $\mathrm{Ra}-226$ and -228 ) that require large sample volumes may not be available. Tailings pore fluid quality by parameter is presented in Table 3.21 of Appendix $A$. Tailings pore fluid quality statistics by parameter are presented in Table 3.22 of Appendix A. Detailed information regarding the water quality of the tailings pore fluid solution is presented in Calculation No.

SRK-05-93-1,2-07-00, Appendix $C$, of this document.

Tailings pore fluid water quality data were evaluated by comparing the statistical averages of the source term to the following:

- The detection limits provided in Table 8.1 of the UMTRA TAD (DOE, 1989). 
- The MCLs specified for inorganic and radionuclide species in 40 CFR Part 192.

- The statistical maximum of background ground water quality at the Burro Canyon disposal site.

Regulated constituents in tailings pore fluid samples are summarized for the Slick Rock NC processing site in Table 3.23 of Appendix A. Samples collected from lysimeters at the NC site had insufficient sample volumes to conduct and/or provide statistical calculations (i.e., less than four analyses available per sampling location) for the following analytes: mercury, nitrate, Ra-226 and -228, cyanide, and sulfide.

Concentrations of 10 inorganic hazardous constituents with MCLs, measured in the tailings pore fluid samples, exceeded the laboratory method detection limit (DOE, 1989) on one or more occasions. These constituents are arsenic, barium, cadmium, chromium, net gross alpha, lead, molybdenum, selenium, silver, and uranium. Concentrations of eight elements listed in the EPA proposed ground water standards that exceed the laboratory method detection limit are antimony, beryllium, copper, nickel, thallium, tin, vanadium, and zinc.

Individual tailings pore fluid measurements that exceed MCLs are presented in Table 3.24 of Appendix A. Mean or median concentrations or activities of six hazardous constituents in tailings pore fluid exceeded the MCLs in lysimeter samples collected from. the NC site. These constituents are arsenic, cadmium, molybdenum, net gross alpha, selenium, and uranium. Additionally, the median or mean concentrations of five hazardous constituents without MCLs exceeded the statistical maximum of background ground water quality for the upper Burro Canyon Sandstone unit at the disposal site. These constituents are antimony, copper, tin, vanadium, and zinc.

\section{Union Carbide processing site}

The uranium processing mill became operational in September 1957 with a design capacity of 350 tons $(320,000 \mathrm{~kg})$ per day and later expanded to 500 tons $(500,000 \mathrm{~kg})$ per day (FBDU, 1977). Ore averaging 0.245 percent $\mathrm{U}_{3} \mathrm{O}_{8}$ and 1.35 percent $\mathrm{V}_{2} \mathrm{O}_{5}$ was delivered to the upgrader from Slick Rock area mines. Dry grinding and air sizing were used to produce a minus 14-mesh product and recover a large portion of the fine fraction. The fine fraction constituted the first concentrate. The coarse-ore fraction was combined with recirculated acid solution; a sand-slime separation then was made on the slurry. The sand product was further acid-leached, washed, and discharged to tailings. The slimes were dewatered and dried as a second concentrate. A third product resulted from ammonia neutralization of part of the pregnant solution. All three products were shipped to UC's Rifle, Colorado, mill for additional processing. About 60 percent of the uranium was contained in the initial dry-fine product and an additional 30 to 35 percent in the other two products (Merritt, 1971). 
The Slick Rock UC site ceased operations in December 1961. Approximately 350,000 tons $\left(320 \times 10^{6} \mathrm{~kg}\right)$ of tailings remain on the site; these sand tailings contain only a small portion of the residual radioactivity. The volume of tailings is provided in Table 1.1 of the remedial action selection report. The tailings pile was contoured, covered with 6 in $(0.2 \mathrm{~m})$ of soil, and vegetated. The pile currently has vegetation covering 20 percent of the surface (FBDU, 1981). A small earth dike separates the pile from the Dolores River. However, the river has eroded the dike, affecting an estimated 25 percent of the stabilized pile and soil cover. Contamination extends downriver and across the mesa from the UC site. Seepage from the UC tailings piles has also entered the ground water in the alluvium beneath the piles.

All mill buildings have been removed from the site, although concrete foundations are present. West of the mill area is an abandoned trailer park, a recreation facility, and a gas sweetener plant.

Tailings at the UC site have an average residual volumetric moisture content of 4.4 percent (ranging from 2.5 to 6.5 percent) (see Attachment 1). Laboratory saturated permeability tests indicate the UC tailings saturated hydraulic conductivity is $160 \mathrm{ft} /$ day $\left(5.6 \times 10^{-2} \mathrm{~cm} / \mathrm{s}\right)$.

To obtain samples of the tailings pore fluid for analysis, two field investigations were conducted to install lysimeters in the tailings pile. Three lysimeters were installed in January 1989. Six additional lysimeters were installed in November 1990. The locations of these lysimeters are shown on Figure 3.1. Tailings pore fluid quality by parameter is presented in Table 3.21 of Appendix A. Tailings pore fluid quality statistics by parameter are presented in Table 3.25 of Appendix A and are summarized for the UC site in Table 3.26 of Appendix A. Detailed information regarding the water quality of the tailings pore fluid solution is presented in Calculation No. SRK-05-93-12-07-00 in Appendix C of this document. Samples collected from lysimeters at the UC site had insufficient sample volumes to conduct and/or provide statistical calculations (i.e., less than four analyses available per sampling location) for Ra-226 and -228 and cyanide.

Eight inorganic hazardous constituents with MCLs exceeded the laboratory method detection limits in UC tailings pore fluid samples on one or more occasions. These constituents are arsenic, barium, cadmium, molybdenum, net gross alpha, nitrate, selenium, and uranium. Concentrations of five potentially hazardous elements listed in the EPA ground water protection standards that exceed the laboratory method detection limit are antimony, copper, tin, vanadium, and zinc.

Mean or median values for hazardous constituents in the tailings pore fluid were compared to the MCLs. Mean or median observed concentrations of five hazardous constituents in tailings pore fluid exceeded the MCLs as shown in Table 3.26 of Appendix A. These constituents are cadmium, molybdenum, nitrate, selenium, and uranium. For hazardous constituents with no MCLs, mean or median tailings pore fluid quality data were compared to the statistical 
maximum of the background ground water quality for the upper Burro Canyon Sandstone unit at the disposal site. The median or mean concentrations of five hazardous constituents without MCLs exceed the statistical maximum concentrations for background ground water quality. These constituents are antimony, copper, tin, vanadium, and zinc.

Both Slick Rock processing sites were screened for priority pollutants, pesticides, and additional regulated compounds. In July 1986 ground water samples were collected from two on-site monitor wells: one at the NC site (503) and the other at the UC site (510). Toluene and di-n-butylphthalate were detected in the ground water sample collected from monitor well 503. However, these compounds were also detected in one or more of the accompanying field blanks in the same concentrations as were detected in well 503. The detection of these compounds is most likely the result of laboratory contamination, since they were detected in both the monitor well sample and the accompanying field blanks. All of the organic compounds analyzed were below detection limits in the sample collected from monitor well 510 at the UC processing site.

\subsubsection{Extent of ground water contamination}

Baseline ground water quality is defined as the representative water quality in a monitor well that has been influenced by uranium processing activities (DOE, 1989). To assess the extent of ground water contamination caused by leachate seepage from the tailings pile and from processing activities, baseline ground water quality data were collected from 3 DOE monitor wells at the NC processing site and 11 DOE monitor wells at the UC processing site. On-site and downgradient monitor well locations are shown on Figure 3.1. The NC monitor wells $(503,504$, and 512) are all screened and filter packed in the Dolores River alluvium. Of the 11 on-site and downgradient monitor wells used for baseline ground water characterization at the UC processing site, 5 monitor wells $(506,507,508,509$, and 510) are screened in the Dolores River alluvium, 3 monitor wells $(554,702$, and 704) are screened in the Entrada Formation, and 3 monitor wells $(669,670$, and 688) are screened in the Navajo Sandstone. Lithologic logs and construction information for these DOE monitor wells are provided in Appendix B.

Baseline ground water quality in the Dolores River alluvium - North Continent site

Baseline ground water quality data by parameter for on-site and downgradient monitor wells screened in the. Dolores River alluvium at the NC site (monitor wells 503, 504, and 512) are provided in Table 3.27 of Appendix A. A statistical treatment of the baseline ground water quality data is provided for the NC processing site in Table 3.28 of Appendix A. Detailed information for the baseline ground water quality data of the Dolores River alluvium is provided in Calculation No. SRK-05-93-14-11-00 in Appendix C. 
The $\mathrm{pH}$ of the baseline alluvial ground water ranges from 6.7 to 7.2 in samples collected from NC monitor wells. TDS concentrations range from 1060 to $4770 \mathrm{mg} / \mathrm{L}$. The on-site and downgradient ground water is predominantly a sodium-sulfate type. Ground water samples influenced by seepage from the tailings at the processing site have a higher percentage of sulfate than is related to uranium processing.

As precipitation infiltrates through the tailings, contaminants seep into the alluvial ground water and migrate horizontally and vertically from the site as a contaminant plume. The extent of ground water contamination is indicated by the distribution of sulfate in the alluvial aquifer as shown in Figure 3.10. Sulfate is used to define the areal extent of a contaminant plume because it is a chemical by-product of the uranium ore processing activities at the Slick Rock sites and is present in ground water at concentrations well above background. As indicated in Figure 3.10, the contaminant distribution represented by sulfate concentrations extends to the Dolores River.

Statistical procedures previously described in Section 3.1.5 were used to assess the baseline ground water quality on-site and downgradient of the Slick Rock processing sites. A summary of regulated constituents in alluvial baseline ground water is presented in Table 3.29 of Appendix A for alluvial NC monitor wells 503, 504, and 512. Measured maximum values of the following six hazardous constituents exceed the MCLs in baseline alluvial ground water at the NC site (Table 3.30 of Appendix A).

Chromium-Chromium was reported as equal to its $\mathrm{MCL}(0.05 \mathrm{mg} / \mathrm{L})$ on one occasion (June 1986) in monitor well 503. However, this measured occurrence is not related to uranium processing activities because the average concentration of chromium measured in lysimeter samples does not exceed laboratory method detection limit. Furthermore, because chromium has not been detected in any other historical sampling rounds, the reported concentration is probably an artifact of laboratory contamination rather than an accurate field measurement.

Molybdenum-Molybdenum slightly exceeded the MCL $(0.10 \mathrm{mg} / \mathrm{L})$ once in each of the three baseline monitor wells $(503$ and 504 in February 1988, and 512 in July 1986). However, the statistical maximum of baseline alluvial ground water $(0.03 \mathrm{mg} / \mathrm{L})$ is less than either the $\mathrm{MCL}$ or the statistical maximum of background alluvial ground water $10.12 \mathrm{mg} / \mathrm{L})$. The alluvial background concentration exceeds the MCL for molybdenum, most likely as a result of nearby localized ore deposits and mining activities. However, because the average concentration of molybdenum in the tailings pore fluid $(0.27 \mathrm{mg} / \mathrm{L})$ is twice the statistical maximum in background ground water quality in the Dolores River alluvium, the uranium processing activities could have influenced the shallow ground water quality downgradient of the NC processing site.

Net gross alpha-Net gross alpha activities have been reported to exceed the MCL on numerous occasions, particularly in monitor well 504, as shown in Table 3.30 of Appendix A. The calculated baseline statistical maximum value 
for net gross alpha (124 pCi/L) significantly exceeds the $\mathrm{MCL}(15 \mathrm{pCi} / \mathrm{L}$ ) and the calculated statistical maximum for alluvial background ground water quality (4.7 pCi/L). Therefore, elevated concentrations of net gross alpha activities are expected in ground waters downgradient from uranium processing activities at the NC site.

Ra-226 and -228-Ra-226 and -228 activities slightly exceeded their MCL in monitor well 512 on two occasions in 1991. Not enough tailings pore water was available to measure the activity of Ra-226 and -228 in the lysimeter samples. However, the background statistical maximum calculated for Ra-226 and $-228(7.80 \mathrm{pCi} / L)$ exceeds the $\mathrm{MCL}(5.0 \mathrm{pCi} / \mathrm{L})$, as well as the baseline statistical maximum $(4.24 \mathrm{pCi} / \mathrm{L})$. Therefore, the observed values may be due to natural processes.

Selenium-Selenium concentrations slightly exceeded the MCL in baseline monitor wells 503 and 504 in May 1990, as shown in Table 3.30 of Appendix A. The baseline statistical maximum value for selenium $(0.015 \mathrm{mg} / \mathrm{L})$ slightly exceeds the MCL $(0.01 \mathrm{mg} / \mathrm{L})$ and exceeds the calculated statistical maximum for alluvial background ground water quality $(0.005 \mathrm{mg} / \mathrm{L})$. Therefore, selenium contamination appears to have resulted from uranium processing activities at the NC site.

Uranium-Uranium concentrations historically have exceeded the MCL for uranium $(0.044 \mathrm{mg} / \mathrm{L})$ in both baseline and background sample populations. For alluvial ground water at the NC site, the baseline statistical maximum is $3.168 \mathrm{mg} / \mathrm{L}$ and the background statistical maximum is $0.045 \mathrm{mg} / \mathrm{L}$. The average uranium concentration calculated for the NC lysimeter samples $(1.77 \mathrm{mg} / \mathrm{L})$ is also above the $\mathrm{MCL}$ for uranium. Therefore, although the background water quality data indicate that the alluvial ground water has elevated uranium concentrations of uranium upgradient of the processing site, uranium concentrations in ground water have also been affected by on-site uranium processing activities.

Measured maximum concentrations of nine elements listed as hazardous constituents in the EPA's final ground water protection standards (60 FR 2854) have equaled or exceeded the statistical maximum values of alluvial background ground water: antimony, copper, cyanide, nickel, sulfide, thallium, tin, vanadium, and zinc. However, only cyanide, sulfide, and tin have baseline statistical maximum values greater than the corresponding background statistical maximum values. Exceedances of these three constituents are discussed below.

Cyanide-Cyanide was reported to slightly exceed the detection limit $(0.01 \mathrm{mg} / \mathrm{L})$ by one measured unit (i.e., a measured concentration of $0.02 \mathrm{mg} / \mathrm{L}$ ) on one occasion. All other analyses of cyanide were below detection limits. As a result, this slight exceedance of the detection limit is considered suspect, and cyanide is not considered to be a hazardous constituent of concern. 
Sulfide-Sulfide concentrations exceeded the alluvial background ground water statistical maximum once (March/April 1991) in each baseline monitor well. These exceedances were slight in two of the wells (503 and 504) and over an order of magnitude high in one well (512). All of these wells have been sampled and analyzed for sulfide on three separate occasions since the exceedances were noted; they have all remained within the range of background ground water quality since the reported exceedances. Furthermore, these occurrences do not appear to be related to uranium processing activities because the average concentration of sulfide measured in lysimeter samples is below the statistical maximum concentration in background ground water.

Tin-Tin concentrations slightly exceeded the alluvial background ground water statistical maximum once (May 1990) in two baseline monitor wells (503 and 504). The baseline statistical values reported in Table 3.28 of Appendix A are ultraconservative because the highest reported detection limits, as well as measured values, are included in the statistical calculations. Monitor wells 503 and $\mathbf{5 0 4}$ were sampled and analyzed for tin on four separate occasions since the exceedances were noted; concentrations have remained less than the detection limits since the reported exceedances. Furthermore, these occurrences do not appear to be related to uranium processing activities because the average concentration of tin measured in lysimeter samples is below the statistical maximum concentration in background ground water.

\section{Baseline ground water quality in the Dolores River alluvium-Union Carbide site}

Baseline ground water quality data by parameter for on-site and downgradient monitor wells screened in the Dolores River alluvium at the UC site (monitor wells 506 through 510) are provided in Table 3.27 of Appendix A. A statistical treatment of the baseline ground water quality data is provided for the UC processing site in Table 3.31 of Appendix A. Detailed information for the baseline ground water quality data of the Dolores River alluvium is provided in Calculation No. SRK-05-93-14-11-00 of Appendix C.

At the Slick Rock UC processing site, the $\mathrm{pH}$ of the baseline alluvial ground water ranges from 6.1 to 7.3. This is slightly more acidic than in UC background monitor wells. On-site and downgradient TDS concentrations range from 259 to $9560 \mathrm{mg} / \mathrm{L}$. TDS concentrations for background ground water at the UC site range from 875 to $1180 \mathrm{mg} / \mathrm{L}$. The on-site and downgradient ground waters are calcium sulfate and sodium sulfate types.

Statistical procedures described in Section 3.1.5 were used to assess the baseline ground water quality on-site and downgradient of the Slick Rock processing sites. Table 3.32 of Appendix A summarizes baseline ground water quality data for UC alluvial monitor wells (506 through 510). Measured maximum values of the following eight hazardous constituents exceed the MCLs in baseline alluvial ground water at the UC site (Table 3.30 of Appendix A).

Cadmium-Cadmium exceeded its MCL $(0.01 \mathrm{mg} / \mathrm{L})$ once (October 1992) in monitor well 508 . This measured occurrence was the first time cadmium was 
detected in monitor well 508. The average concentration of cadmium measured in lysimeter samples was four times greater than the MCLs. Therefore, this exceedance may be related to uranium mine tailings.

Chromium-Chromium was reported equal to its $\mathrm{MCL}(0.05 \mathrm{mg} / \mathrm{L})$ once (July 1986) in monitor well 510. However, this occurrence is not related to uranium processing activities because the average concentration of chromium measured in lysimeter samples does not exceed the laboratory method detection limit. Furthermore, because chromium has not been detected in any other historical sampling rounds, the reported concentration may be an artifact of laboratory contamination rather than an accurate field measurement.

Molybdenum-Molybdenum frequently exceeds the MCL $(0.10 \mathrm{mg} / \mathrm{L})$ in all of the UC baseline monitor wells. A molybdenum isopleth map for the alluvial aquifer is presented in Figure 3.11. The statistical average of baseline alluvial ground water $(0.22 \mathrm{mg} / \mathrm{L})$ exceeds the $\mathrm{MCL}$ and the statistical maximum of background alluvial ground water $(0.11 \mathrm{mg} / \mathrm{L})$. The alluvial background concentration exceeds the MCL for molybdenum, probably as a result of nearby ore deposits and mining activities unrelated to the UMTRA Project. The average concentration of molybdenum in the tailings pore fluid $(3.63 \mathrm{mg} / \mathrm{L})$, collected from lysimeters at the UC site, is over an order of magnitude greater than the statistical maximum of background ground water quality in the Dolores River alluvium, indicating that the uranium processing activities have influenced the shallow ground water quality downgradient of the UC processing site.

Net gross alpha - Net gross alpha activities have been reported to exceed the MCL on numerous occasions, as shown in Table 3.30 of Appendix A. The calculated baseline statistical maximum value for net gross alpha $(17.12 \mathrm{pCi} / \mathrm{L})$ slightly exceeds the MCL (15 pCi/L). Elevated net gross alpha activities are probably the result of uranium processing activities at the UC site.

Nitrate-Nitrate concentrations have significantly and regularly exceeded the MCL $(44.0 \mathrm{mg} / \mathrm{L})$, particularly in UC monitor wells 508 and 510 . A nitrate isopleth for the alluvial aquifer is presented in Figure 3.12. The average concentration of nitrate in the tailings pore fluid $(210.0 \mathrm{mg} / \mathrm{L})$ collected from lysimeters at the UC site is three times greater than the $\mathrm{MCL}$ and over an order of magnitude greater than the statistical maximum of alluvial background ground water quality $(2.0 \mathrm{mg} / \mathrm{L})$, indicating that uranium processing activities have influenced the quality of shallow ground water downgradient of the UC processing site.

Ra-226 and -228-Ra-226 and -228 activities slightly exceeded the MCL $(5.0 \mathrm{pCi} / \mathrm{L})$ in three UC alluvial monitor wells $(506,508$, and 509$)$. Not enough tailings pore water was available to measure the activity of Ra-226 and -228 in the lysimeter samples. The background statistical maximum calculated for $\mathrm{Ra}-226$ and $-228(2.52 \mathrm{pCi} / \mathrm{L})$ is within the same range as the baseline statistical maximum (2.70 pCi/L). 


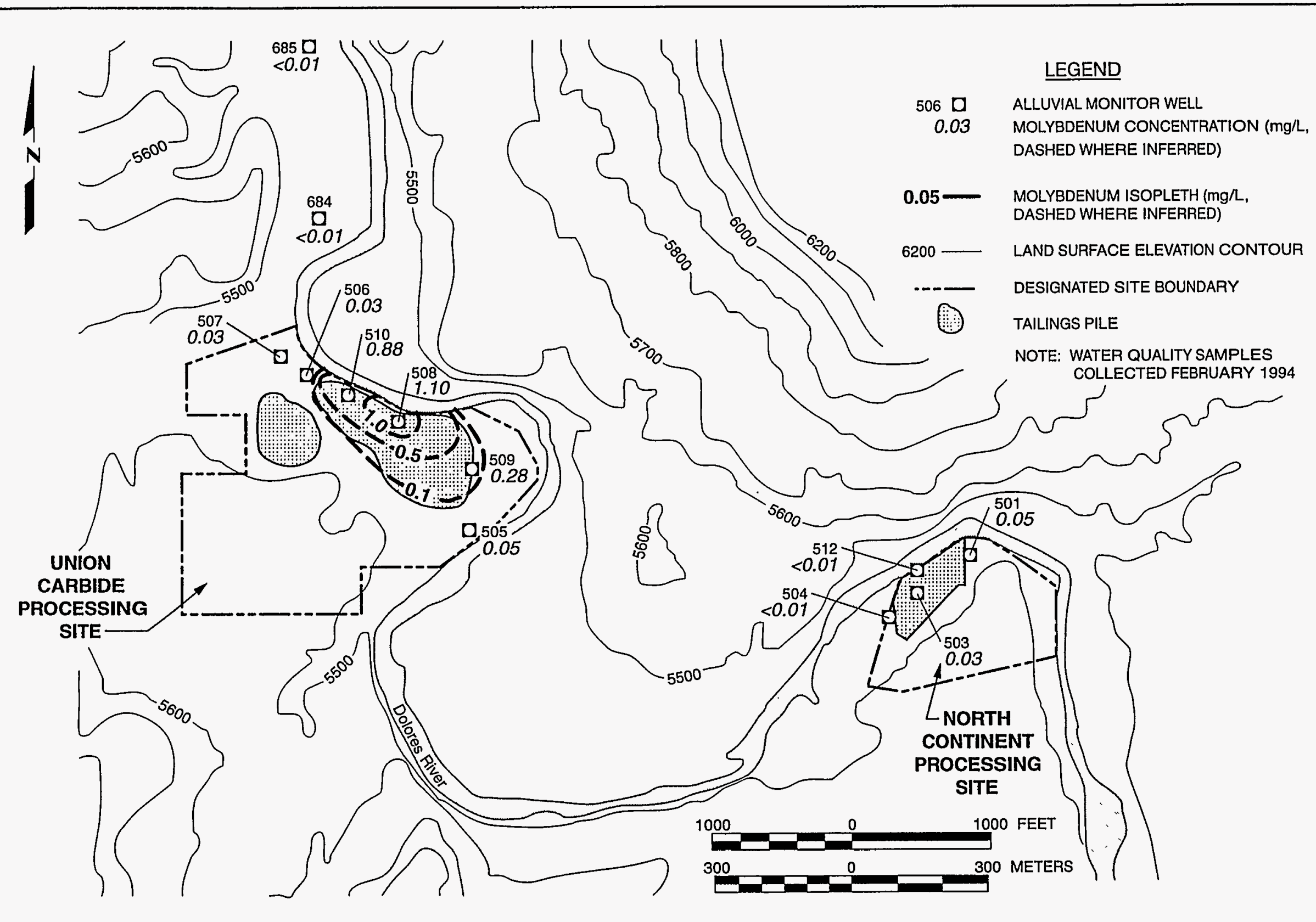

FIGURE 3.11

MOLYBDENUM DISTRIBUTION IN ALLUVIAL GROUND WATER NEAR SLICK ROCK, COLORADO 


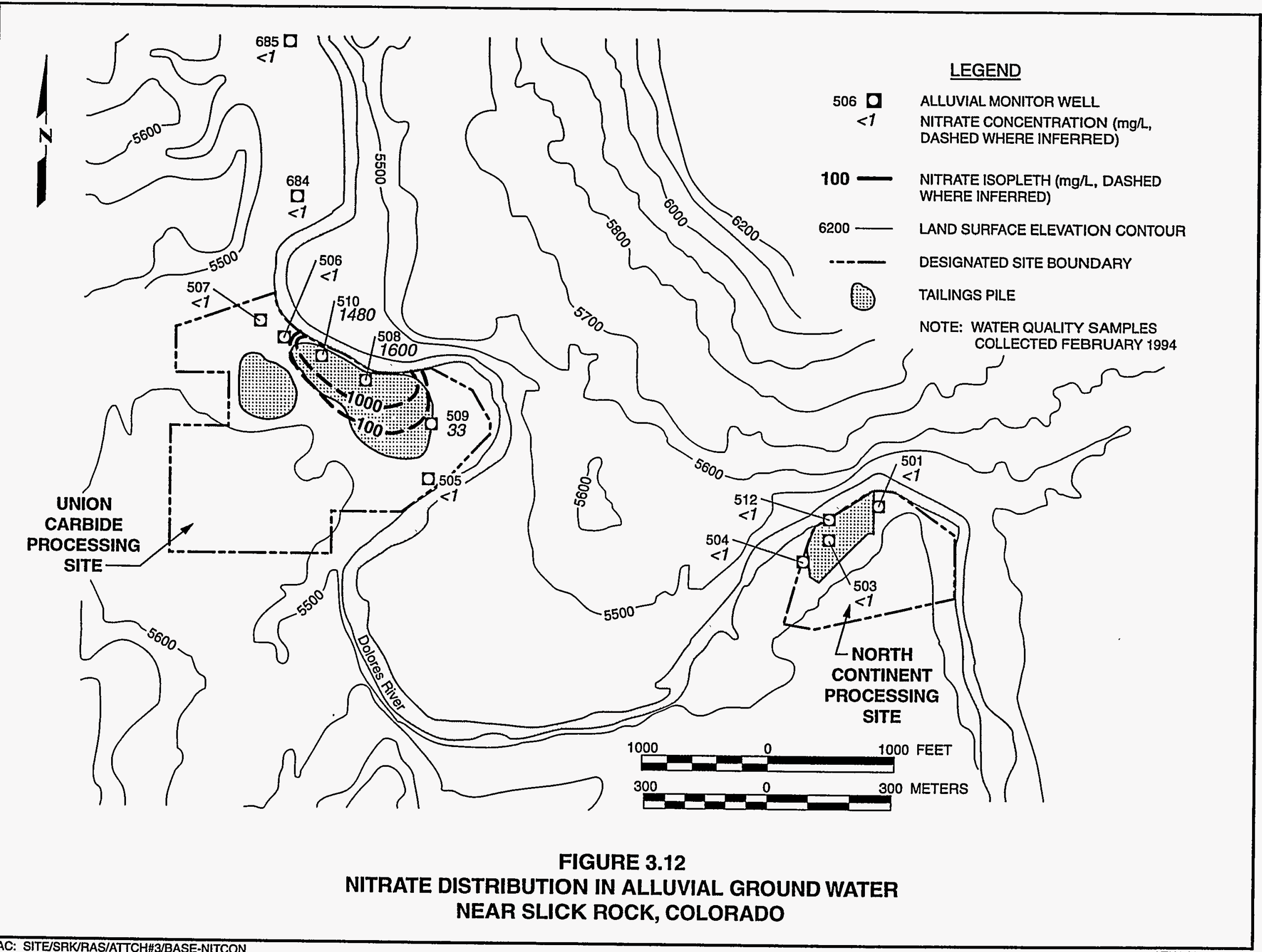


Selenium-Selenium concentrations frequently exceed the MCL in UC baseline monitor wells. The baseline statistical maximum value for selenium $(0.065 \mathrm{mg} / \mathrm{L})$ exceeds the $\mathrm{MCL}(0.01 \mathrm{mg} / \mathrm{L})$ and the calculated statistical maximum for alluvial background ground water quality $(0.007 \mathrm{mg} / \mathrm{L})$. Therefore, elevated concentrations of selenium are expected to result from uranium processing activities at the UC site.

Uranium-Uranium concentrations historically have exceeded the $\mathrm{MCL}$ for uranium $(0.044 \mathrm{mg} / \mathrm{L})$ in the baseline UC alluvial ground water samples. A uranium isopleth for the alluvial aquifer is presented in Figure 3.13. The baseline statistical maximum is $0.095 \mathrm{mg} / \mathrm{L}$, twice the $\mathrm{MCL}$. The background statistical maximum is $0.033 \mathrm{mg} / \mathrm{L}$ for alluvial ground water at the UC site. The average uranium concentration calculated for the NC lysimeter samples $(0.26 \mathrm{mg} / \mathrm{L})$ is also above the $\mathrm{MCL}$ for uranium. Therefore, uranium concentrations in shallow ground water have been affected by on-site uranium processing activities.

Measured maximum concentrations of eight elements listed as hazardous constituents in the final EPA ground water protection standards (60 FR 2854) equaled or exceeded the statistical maximum background values. These are antimony, copper, nickel, sulfide, thallium, tin, vanadium, and zinc. However, only thallium and vanadium have baseline statistical maximum values that are greater than the corresponding background statistical maximum values. Exceedances of these two constituents are discussed below.

Thallium-Thallium has ultraconservative baseline statistical values because the highest reported detection limits, as well as measured values, are included in the statistical calculations. In fact, thallium has never been detected in any of the UC baseline monitor wells. Similarly, thallium has not been detected in the UC tailings pore fluid. Therefore, thallium is not a hazardous constituent of concern.

Vanadium - Vanadium concentrations have exceeded the statistical maximum for background alluvial ground water. The baseline statistical maximum $(0.23 \mathrm{mg} / \mathrm{L})$ is within the same range as the background statistical maximum $(0.24 \mathrm{mg} / \mathrm{L})$. The average concentration of vanadium in the UC tailings pore fluid is $0.18 \mathrm{mg} / \mathrm{L}$, less than the statistical maximum of background. Therefore, the vanadium concentrations may reflect natural variation in background concentrations and may be unrelated to uranium processing activities.

\section{Baseline ground water quality in the Entrada Formation - Union Carbide site}

Baseline ground water quality in the Entrada Formation at the UC site was characterized by monitoring three wells $(554,702$, and 704$)$. Construction information for these three baseline monitor wells, screened and filter packed in the Entrada Formation, is provided in Table 3.2 of Appendix A. Baseline ground water quality data by parameter for on-site and downgradient monitor wells screened in the Entrada Formation are provided in Table 3.33 of Appendix A. A statistical treatment of the baseline ground water quality data is provided for the 
UC processing site in Table 3.34 and summarized in Table 3.35 of Appendix A. None of the NC monitor wells are screened in the Entrada Formation. However, because the UC and NC processing sites are within a mile of each other and have very similar hydrostratigraphic and chemical characteristics, the baseline ground water quality of the Entrada Formation at the UC site is expected to be representative of that at the NC site. Detailed water quality information for the baseline water quality of the Entrada Formation is provided in Calculation No. SRK-05-93-14-11-00 in Appendix C.

The $\mathrm{pH}$ of the baseline ground water flowing through the Entrada Formation ranges from 6.9 to 8.0 . TDS concentrations range from 360 to $2680 \mathrm{mg} / \mathrm{L}$. The on-site and downgradient Entrada ground waters are predominantly calcium bicarbonate and magnesium bicarbonate, although monitor well 554 has a magnesium chloride water.

In five hazardous constituents, measured concentrations or activities exceeded the MCL on one or more occasion: barium, net gross alpha, nitrate, radium-226 and -228 , selenium, and uranium, as shown in Table 3.36 of Appendix A. Of these, only nitrate and selenium have calculated baseline statistical maximum values that exceed the MCLs.

Nitrate-Nitrate concentrations average $84.6 \mathrm{mg} / \mathrm{L}$ in monitor well 702, and routinely exceeded the $\mathrm{MCL}(44.0 \mathrm{mg} / \mathrm{L})$, while concentrations in monitor wells 554 and 704 historically averaged $1.0 \mathrm{mg} / \mathrm{L}$ and $10.0 \mathrm{mg} / \mathrm{L}$. Nitrate concentrations also significantly exceeded the $\mathrm{MCL}$ in samples collected from the lysimeters and alluvial ground water monitor wells. As a result, the elevated concentrations of nitrate detected in monitor well 702 are probably related to uranium processing activities.

Selenium-Selenium routinely exceeded its $\mathrm{MCL}(0.01 \mathrm{mg} / \mathrm{L})$ in samples collected from monitor wells 702 and 704 . The selenium statistical maximum for background ground water quality in the Entrada Formation $(0.013 \mathrm{mg} / \mathrm{L})$ slightly exceeds the MCL. Selenium concentrations also exceeded the MCL in Iysimeter and baseline alluvial ground water samples. As a result, elevated selenium concentrations in the Entrada Formation at the UC processing site may be related to uranium processing activities.

Measured maximum concentrations of five elements listed as hazardous constituents in final EPA ground water protection standards (60 FR 2854) equaled or exceeded the statistical maximum background values: sulfide, thallium, tin, vanadium, and zinc. However, only sulfide, tin, and zinc have baseline statistical maximum values that are greater than the corresponding background statistical maximum values, as shown in Table 3.35 of Appendix A. Exceedances of these three constituents are discussed below.

Sulfide-Sulfide resulting from uranium processing could have seeped into the Entrada Formation while the sulfide remaining in the tailings was oxidized to sulfate; exceedances may be related to processing activities. 
Tin-Tin has baseline statistical values that are ultraconservative because the highest reported detection limits, as well as measured values, are included in the statistical calculations. In fact, tin has never been detected in any of the UC baseline monitor wells. Therefore, tin is not a hazardous constituent of concern.

Zinc-Zinc concentrations slightly exceeded the statistical maximum for background alluvial ground water in baseline monitor wells 702 and 704, on one or more occasions. The baseline statistical maximum $(0.01 \mathrm{mg} / \mathrm{L})$ exceeds the background statistical maximum $(0.005 \mathrm{mg} / \mathrm{L})$.

\section{Baseline ground water quality in the Navajo Sandstone-Union Carbide site}

Baseline ground water quality in the Navajo Sandstone was characterized by monitoring three wells at the UC site $(669,670$, and 688). Monitor well locations are shown in Figure 3.1. Ground water quality data by parameter are provided in Table 3.37 of Appendix $A$ and ground water quality statistics are provided in Table 3.38 of Appendix A. Table 3.39 of Appendix A summarizes regulated constituents in the Navajo Sandstone baseline ground water.

The $\mathrm{pH}$ of ground water measured in baseline monitor wells screened in the Navajo Sandstone ranges from 7.0 to 8.9 at the UC site. TDS concentrations range from $222 \mathrm{mg} / \mathrm{L}$ to $1760 \mathrm{mg} / \mathrm{L}$. Baseline ground water quality in the Navajo Sandstone is characterized as a calcium bicarbonate type.

Three hazardous constituent measurements equaled or exceeded the MCLs in ground water samples collected from the baseline Navajo Sandstone monitor wells, as shown in Table 3.40 of Appendix A. These hazardous constituents include molybdenum, Ra-226 and -228 , and uranium; however, the observed exceedances are infrequent. The summary of regulated constituents provided in Table 3.39 of Appendix A shows that all of these constituents have statistical maximum values below the MCLs.

Measured maximum concentrations of three elements listed as hazardous constituents in final EPA ground water protection standards (60 FR 2854) have equaled or exceeded the statistical maximum background values. These are antimony, vanadium, and zinc. Of these constituents, only zinc has a baseline statistical maximum value greater than the corresponding background statistical maximum value, as shown in Table 3.39 of Appendix A. Concentrations of zinc exceeded Navajo Sandstone background statistical maximum value in each of the three baseline monitor wells on one or more occasions.

\subsubsection{Geochemical conditions}

Geochemical conditions that control the transport of the hazardous constituents from the tailings into ground water and by ground water within the aquifers at the processing site include 1) the chemical composition, $\mathrm{pH}$, and Eh of the tailings pore fluid, soil pore fluid, and ground water; and 2) the reactive mineralogy of the subsoils and aquifer materials. The chemical compositions, $\mathrm{pH}$, and Eh of the various fluids determine the types of 
precipitation/coprecipitation reactions that can occur to control the migration rate of contaminants of concern. The chemical compositions, $\mathrm{pH}$, and Eh of the fluids combined with the reactive mineralogy of the subsoils and aquifer materials determine the types of adsorption reactions that can occur involving contaminants of concern.

Precipitation and coprecipitation reactions can result from 1) acid-neutralization reactions, 2) a general condition of oversaturation in the tailings seepage, and 3) oxidation-reduction reactions. The acid-neutralization reactions occur as a result of the seepage of tailings leachate into subsurface units containing carbonates and other acid-neutralizing phases. Neutralization of acid leachate causes the precipitation of metals originally in the leachate. Because the tailings fluids at the UC and NC sites are near-neutral in pH (5.9 to 7.9), acidneutralization reactions will not be a major retardation mechanism for the contaminants of concern at the processing site.

The tailings pore fluids are generally oversaturated in gypsum, calcite, quartz and, locally, other solid phases. Although such oversaturation eventually leads to precipitation, the precipitation reactions commonly are slow to occur. In general, quartz precipitation rates are much slower than gypsum rates at the same level of oversaturation. Therefore, gypsum tends to precipitate from oversaturated solutions before quartz. As these phases precipitate in the pore spaces of the aquifers, some trace contaminants of concern may coprecipitate with them, depending on the saturation level of the contaminant species. For example, radium could precipitate with gypsum or barite and cadmium and zinc could coprecipitate with calcite.

The oxidation-reduction precipitation reactions are the most important class of precipitation reactions at the processing sites. In many cases, either the oxidized or reduced form of a contaminant or major ion is much more insoluble than the other form. For example, the oxidized form of uranium $\left(U^{+6}\right)$ is much more soluble than the reduced form $\left(U^{+4}\right)$. Conversely, the reduced forms of iron $\left(\mathrm{Fe}^{+2}\right)$ and manganese $\left(\mathrm{Mn}^{+2}\right)$ are much more soluble than the oxidized forms $\left(\mathrm{Fe}^{+3}\right.$ and $\left.\mathrm{Mn}^{+4}\right)$.

The geochemical parameter that gauges whether a given constituent is in an oxidized or reduced form is Eh. The Eh and several related parameters were measured in most wells at the NC and UC sites. In general, the wells in the alluvial aquifers at and immediately downgradient of the tailings piles (i.e., monitor wells 503 and 504 at the NC site and monitor wells 506 and 507 at the UC site) show low to moderately reducing conditions ( 80 to 280 millivolts [mVl). In addition, one monitor well screened in the Entrada Formation downgradient of the mill area at the UC site (well 554) also shows reducing conditions (100 mV). Oxidizing conditions (i.e., $>400 \mathrm{mV}$ ) are found in most of the other wells at both sites.

The reducing conditions in waters immediately downgradient from the NC and UC sites could immobilize selenium and uranium on the aquifer matrix. The reducing conditions will also maintain nitrogen in the form of ammonium instead 
of nitrate or nitrite. On the other hand, the mobility of iron and manganese will be enhanced by the reducing conditions. However, as the reducing ground waters mix with oxidizing waters downgradient, the iron and possibly the manganese will be oxidized and precipitate out of solution. As iron precipitates out of solution, it could cleanse the water of other contaminants through coprecipitation and adsorption reactions.

As the reducing conditions in the alluvial aquifers return to naturally oxidizing conditions, the contaminants immobilized by reduction precipitation reactions may be remobilized, depending on the oxidation potential achieved in the aquifer. For example, any uranium immobilized by reduction will undoubtedly be remobilized. Selenium and nitrogen may or may not be converted to more mobile species, depending on the natural oxidation potential in the aquifer.

Adsorption reactions involve the attachment of simple and complex ions to the exterior surfaces of minerals in the aquifer matrix and/or ion exchange on interior exchange sites. Although the details of the surface attachment reactions are not completely known, it is well known that surfaces of iron and manganese oxides and oxyhydroxides have a high affinity for transition metals and oxyanions such as molybdate. The metals and oxyanions do not all have the same affinity for these oxides and oxyhydroxides. Based on theoretical derivations, the relative affinities cannot be reliably predicted in complex natural systems such as the ground water associated with uranium mill tailings sites. These relative affinities must be measured in a laboratory by either batch or column experiments.

The ion exchange reactions are better understood and largely involve cation exchange. However, even the relative affinities of mineral phases for cationic contaminants such as Ra-226, cadmium, and zinc must be determined experimentally in batch and/or column experiments.

\subsubsection{Ground water use, value, and alternative supplies}

No municipal water supply wells exist at or in the vicinity of Slick Rock, Colorado. The community of Slick Rock consists of a combination restaurant/ general store. About 10 people, including residents of two trailers in the Slick Rock vicinity, live within $10 \mathrm{mi}(16 \mathrm{~km})$ of the UC and NC sites.

A well survey conducted in February 1994 has indicated that 18 private wells exist (currently or historically) within a $2-\mathrm{mi}(3-\mathrm{km})$ radius of the Slick Rock UC and NC processing sites. Fourteen of these wells are registered with the Colorado Division of Water Resources, and the remaining four are nonregistered. Information regarding well permits, sampling dates, well construction, ground water units of completion, well status, and water use is provided in Table 3.41. Approximate locations of these wells are provided in Figure 3.1. Well permit information indicates that the nearby private wells are screened in the alluvium and the Entrada and Navajo Sandstone Formations. The 1994 well survey and follow-up water sampling have indicated that of the 18 private wells, 2 are actively used, 11 existing wells are presumed to be inactive, 3 wells adjacent to 
the site that could not be located in the field are presumed to be sealed, and the status of 2 registered wells located approximately $2 \mathrm{mi}(3 \mathrm{~km})$ east (upgradient of the processing sites) is unknown because of limited roadway access. Three private wells are downgradient of the UC site and are expected to be beyond the reach of the contaminant plume, as evidenced by the water quality in downgradient alluvial DOE monitor wells 684 and 685 . The remainder of the wells are upgradient or crossgradient of the UC site. Of the two active wells, one (well 672) is crossgradient and across the Dolores River from the NC and UC sites. Water quality monitoring conducted in February 1994 indicates that the water quality in well 672 is not affected by the site. A ground water flow boundary appears to follow the course of the Dolores River and is expected to hydrologically separate three wells from the NC tailings, which are on the opposite side of the Dolores River from the private wells. The other active well is upgradient of both sites.

In addition to the 18 private wells, a collector system that taps the Entrada Formation is located along a cliff face approximately $1500 \mathrm{ft}(450 \mathrm{~m})$ west (upgradient) of the UC site. This collector system appears in good shape and is believed to be used for livestock.

Staff from the Bureau of Land Management (BLM) and USGS have reported, as of February 1994, that they are unaware of any additional ground water users within $2 \mathrm{mi}(3 \mathrm{~km})$ of the Slick Rock processing sites.

Surface water from the Dolores River is another potential source of water in the vicinity of the processing site. Water from the Dolores River may be used temporarily to suppress dust, decontaminate vehicles, and compact tailings. Rights to this surface water will be secured prior to surface remedial action construction.

\subsection{DISPOSAL SITE}

\subsubsection{Previous investigations}

Three previous site-specific hydrologic investigations were conducted in the vicinity of the Burro Canyon disposal site. In 1985, preliminary testing was conducted southeast of the current Burro Canyon disposal site location. These initial site characterization activities consisted of excavating eight test pits and three boreholes to determine whether the location was suitable as a relocated disposal site. The area was found to be suitable for tailings disposal (DOE, 1986).

A second detailed site investigation was conducted during 1990 and 1991 at the current Burro Canyon site. During 1990, the DOE installed 14 monitor wells, 4 boreholes, and 13 test pits to characterize lithology, ground water elevations and hydraulic gradients, aquifer properties, and ground water quality at the disposal site. 
Additional testing was conducted in 1991 in response to two issues raised by the Colorado Department of Public Health and Environment (CDPHE): 1) the extent of the mudstone aquitard between the upper and middle sandstone units of the Burro Canyon Formation southeast (downgradient) of the proposed disposal site, and 2) the degree of downgradient saturation in the upper sandstone unit. An exploration core hole was drilled approximately $900 \mathrm{ft}$ $(300 \mathrm{~m})$ from the edge of the disposal cell and to a total depth of $179 \mathrm{ft}$ $(54.6 \mathrm{~m})$ below land surface. The core hole confirmed that the Burro Canyon mudstone and sandstone units were continuous. A monitor well was placed approximately $10 \mathrm{ft}(3 \mathrm{~m})$ north of the exploration core hole and was completed to the base of the upper Burro Canyon sandstone unit for a total depth of $113 \mathrm{ft}$ $(34.4 \mathrm{~m})$. A second monitor well, placed approximately $650 \mathrm{ft}(198 \mathrm{~m})$ southeast of the edge of the proposed disposal cell, was drilled through the upper sandstone unit (from 72 to $101 \mathrm{ft} \mathrm{[22} \mathrm{to} 30.8 \mathrm{~m}]$ ), the mudstone aquitard (from 101 to $169 \mathrm{ft}[30.8$ to $51.5 \mathrm{ml}$ ), and $10 \mathrm{ft}(3 \mathrm{~m})$ into the middle sandstone unit for a total depth of $179 \mathrm{ft}(54.6 \mathrm{~m})$. This well was then backfilled with bentonite and a screen was installed at the base of the upper sandstone unit from 80 to $100 \mathrm{ft}(24$ to $30 \mathrm{~m})$, with filter pack material from 65 to $102 \mathrm{ft}(20$ to $31.1 \mathrm{~m})$. Geophysical logs (natural gamma, gamma-gamma, neutron, and resistivity) were run in the exploratory core hole and five DOE monitor wells.

The locations of the monitor wells and piezometers are shown on Figure 3.14. Monitor well information is presented in Table 3.42 of Appendix A. In the following discussion, all depths recorded are measured from ground surface. Lithologic logs and monitor well construction information are provided in Appendix B to Attachment 3.

The chemical and mineralogical properties of Burro Canyon sediment samples were characterized in 1990 by Pittsburgh Mineral \& Environmental Technology, Inc. (PMET, 1990). Sediment samples were collected from the Dakota Sandstone (sandstones and shales) and from Burro Canyon (mudstones and sandstones). The laboratory work included chemical analyses, polarized light microscopy with modal analyses, and $X$-ray diffraction analyses.

Relatively undisturbed samples were recovered for visual inspection and laboratory tests to determine unsaturated hydraulic conductivity, porosity, and other selected parameters. Five sediment samples were collected from mudstones and claystones of the Burro Canyon Formation. Laboratory analyses were conducted to determine moisture contents, bulk densities, porosities, saturated hydraulic conductivities, soil moisture retention curves, and particle densities (Daniel B. Stephens \& Associates, Inc., 1991).

Ground water elevations were measured to map the potentiometric surface to determine the direction of ground water flow and hydraulic gradients. Bailer recovery tests, aquifer performance tests, and slug injection tests were performed to measure hydraulic parameters of the upper, middle, and lower Burro Canyon sandstone units. Water quality samples were collected from 


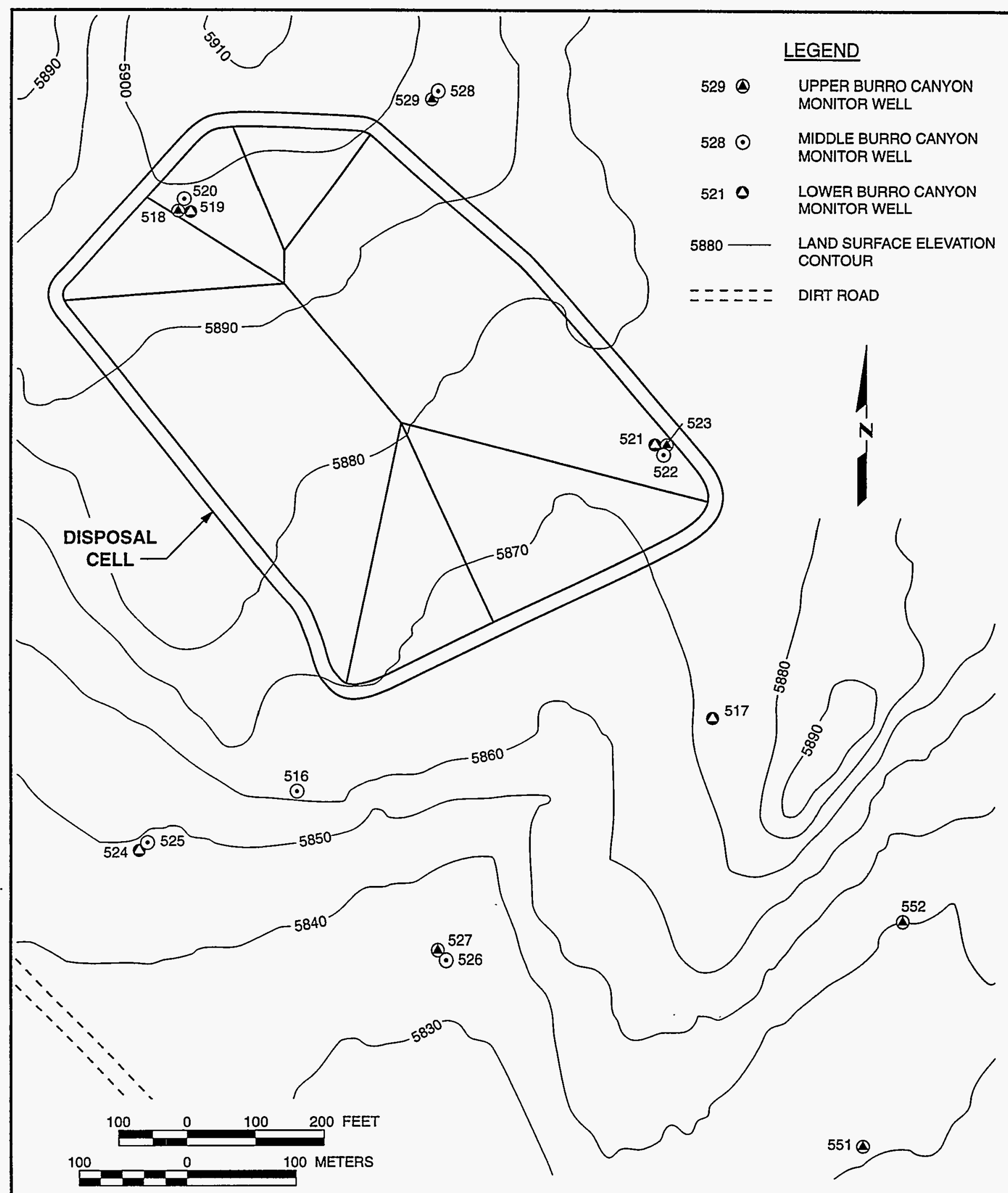

FIGURE 3.14

MONITOR WELL LOCATIONS

BURRO CANYON DISPOSAL SITE NEAR SLICK ROCK, COLORADO 
selected wells in the Burro Canyon sandstone units to establish background water quality at the disposal site.

\subsubsection{Geology and hydrostratigraphy}

To characterize the hydrogeology of the site in the Burro Canyon Formation, the DOE installed six monitor wells in the upper sandstone unit, six wells in the middle sandstone unit, and four wells in the lower sandstone unit. Construction information for these monitor wells is summarized in Table 3.42 of Appendix A. Detailed lithologic logs and construction information are presented in Appendix B.

The Burro Canyon disposal site is on a weathered pediment of Dakota Sandstone that overlies the interbedded mudstones, siltstones, and sandstones of the Burro Canyon Formation. The lowest unit of Dakota Sandstone consists primarily of low-permeability carbonaceous shale and mudstone. Two thin sandstone layers ranging in thickness from 1 to $6 \mathrm{ft}(0.3$ to $2 \mathrm{~m})$ are interbedded with the shales and mudstones in the lower Dakota Sandstone. The Dakota Sandstone is unsaturated in the site vicinity and is therefore not discussed in detail in this report. Ground water beneath the site occurs in the sandstone units of the Burro Canyon Formation.

The Burro Canyon Formation is relatively uniform in thickness in the vicinity of the site (Shawe et al., 1968). The grade of the Burro Canyon Formation is approximately 3 percent, as discussed in Section 3.1 of Attachment 2. Three water-bearing sandstone units lie beneath the disposal cell. The tops of these sandstone units generally are within the Burro Canyon Formation at approximate depths of 100,200 , and $300 \mathrm{ft}(30,60$, and $90 \mathrm{~m})$, and are described as the upper, middle, and lower units, respectively. They are fine- to medium-grained sandstone layers ranging from 25 to $75 \mathrm{ft}(7.6$ to $23 \mathrm{~m})$ in thickness and are separated by thick interbedded claystone, mudstone, and siltstone sequences (hereafter referred to as mudstone), as shown in Figure 3.15. The three sandstone units are hydrogeologically separated from each other, as evidenced by 1) differences in the geologic and hydraulic properties of the sandstone versus the mudstone units, 2) differences in potentiometric surfaces for each unit, and 3) differences in the ground water geochemistry of each unit. The low-permeability mudstone/claystone units above the upper sandstone unit and between the upper, middle, and lower sandstone units are effective aquitards, inhibiting the potential migration of fluids and contaminants from the area of the disposal cell. The presence and movement of ground water is discussed in greater detail in Section 3.2.3.

A geologic northwest-southeast cross section is provided for the disposal site in Figure 3.15. As indicated on this figure, the thicknesses of the units remain relatively uniform. Ground water elevations measured in each monitor well at the Burro Canyon disposal site from February 1990 to November 1992 are provided in Table 3.43 of Appendix $A$. 


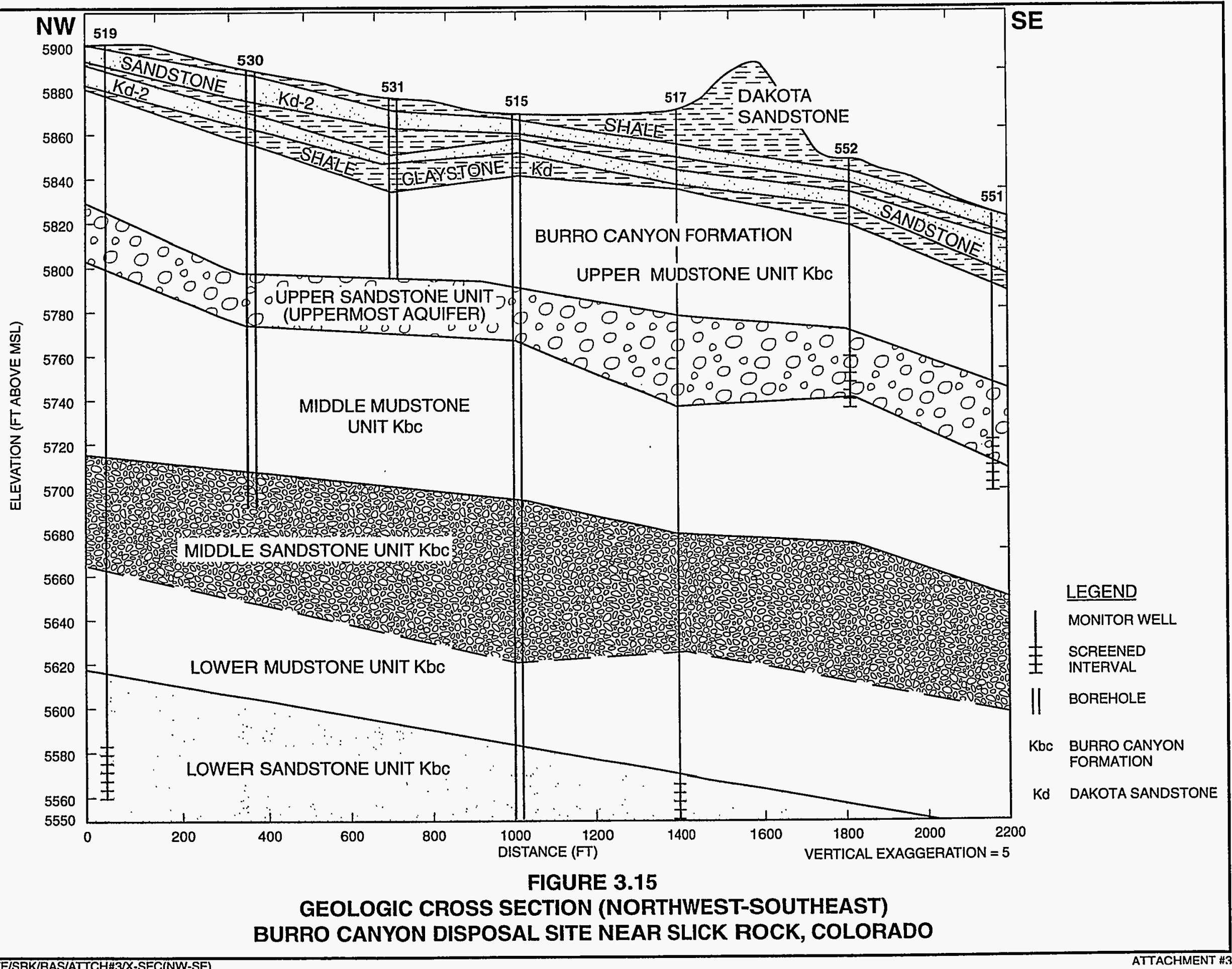




\subsubsection{Presence and movement of ground water}

\section{Burro Canvon upper sandstone unit}

The upper sandstone unit of the Burro Canyon Formation (including some interbedded mudstone layers) ranges from 20 to $40 \mathrm{ft}(6$ to $12 \mathrm{~m}$ ) thick beneath the disposal cell footprint, and underlies approximately $50 \mathrm{ft}(15 \mathrm{~m})$ of mudstone. The Burro Canyon upper sandstone unit is the uppermost aquifer; ground water occurs under unconfined conditions and the yield is very low. Ground water movement is to the southeast, as shown in Figure 3.16. The top of the upper sandstone unit occurs from 50 to $100 \mathrm{ft}(20$ to $30 \mathrm{~m}$ ) below land surface. The depth to the water table ranges from 75 to $110 \mathrm{ft}(23$ to $34 \mathrm{~m}$ ) below land surface in the upper sandstone unit. Figure 3.17 shows that ground water elevations have remained constant. Recharge to the upper sandstone unit is expected to be from infiltrating the surface outcrop (upgradient of the site). Additional hydraulic information for this unit is provided in Section 3.2.4.

\section{Burro Canyon middle sandstone unit}

The middle sandstone unit ranges from 55 to $75 \mathrm{ft}(17$ to $23 \mathrm{~m})$ thick beneath the site and underlies approximately 60 to $70 \mathrm{ft}(18$ to $21 \mathrm{~m})$ of mudstone. The top of the middle sandstone unit occurs at a depth between 140 and $190 \mathrm{ft}$ (42 to $58 \mathrm{~m}$ ) below land surface in the vicinity of the disposal cell footprint. Ground water occurs under confined conditions and has an upward hydraulic gradient; the potentiometric surface is approximately $40 \mathrm{ft}(12 \mathrm{~m})$ above the top of the middle sandstone unit. A potentiometric surface contour map of the middle sandstone unit is provided in Figure 3.18. Ground water flows to the southeast. Ground water elevations have remained constant, as shown in Figure 3.19.

Recharge to the middle sandstone unit occurs upgradient from the disposal cell, approximately 0.25 to $0.75 \mathrm{mi}(0.40$ to $1.2 \mathrm{~km})$ northeast of the site. Sandstone beds outcrop along the east limb of the Disappointment syncline and intercept tributaries to the Nicholas Wash drainage system. Ground water then flows to the south-southeast and eventually dissipates (discharges) into the surrounding geologic strata of the Burro Canyon Formation south of the Burro Canyon disposal site.

\section{Burro Canyon lower sandstone unit}

The lower water-bearing sandstone unit beneath the disposal cell is $39 \mathrm{ft}(12 \mathrm{~m})$ thick, and the top of the unit is approximately 250 to $300 \mathrm{ft}(76$ to $91 \mathrm{~m})$ below land surface. A potentiometric surface contour map of the lower sandstone unit is provided in Figure 3.20. Ground water in this unit is confined by the thick sequence of overlying low-permeability mudstones and siltstones of the Burro Canyon Formation. Ground water has an upward gradient with the potentiometric surface 169 to $240 \mathrm{ft}(51.5 \mathrm{fo} 73 \mathrm{~m})$ above the top of the lower sandstone unit and averaging $52 \mathrm{ft}(16 \mathrm{~m})$ above the middle sandstone unit. The lower sandstone unit has an extremely low velocity and well yield. Ground water elevations have remained constant, as shown in Figure 3.21. Vertical 


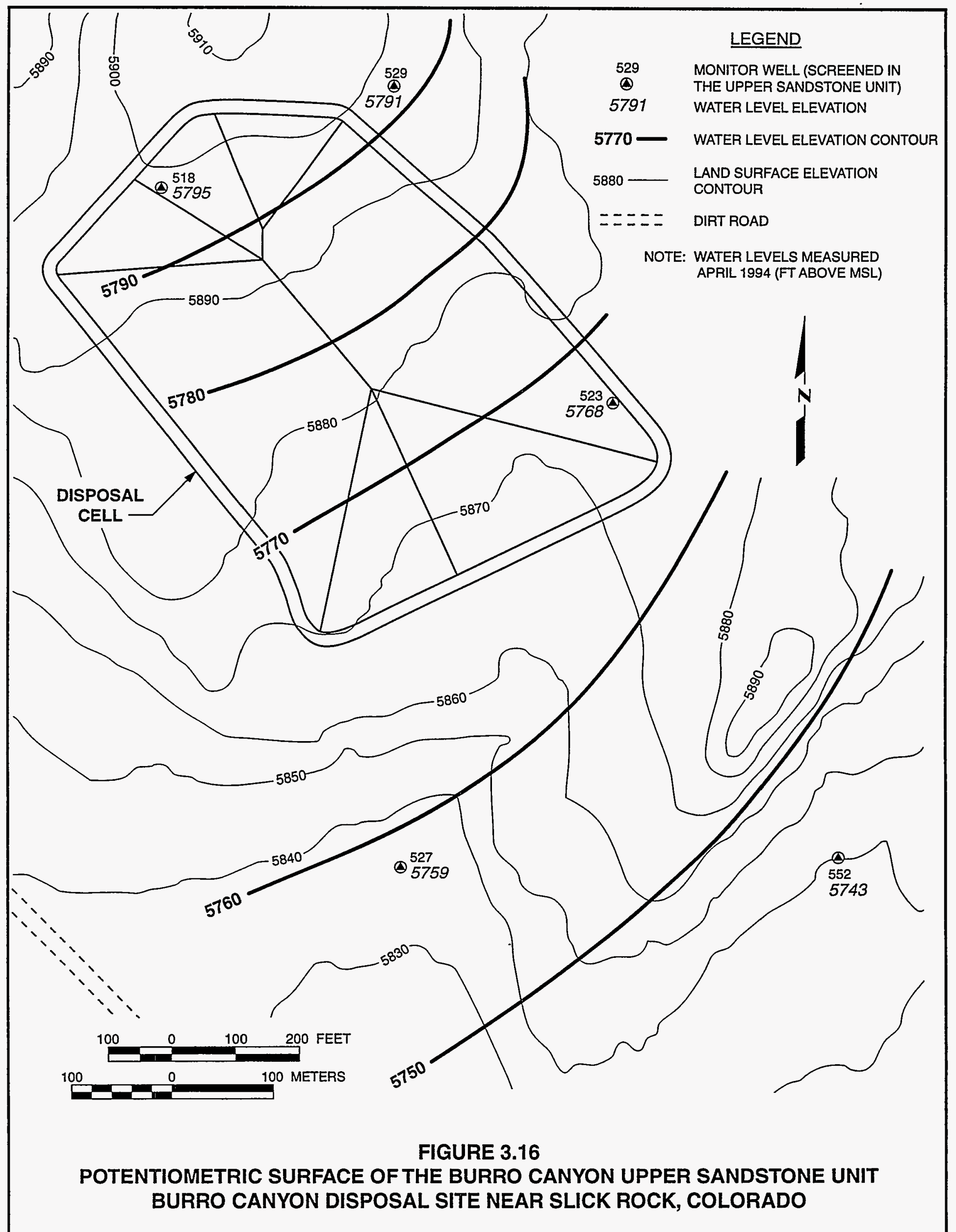




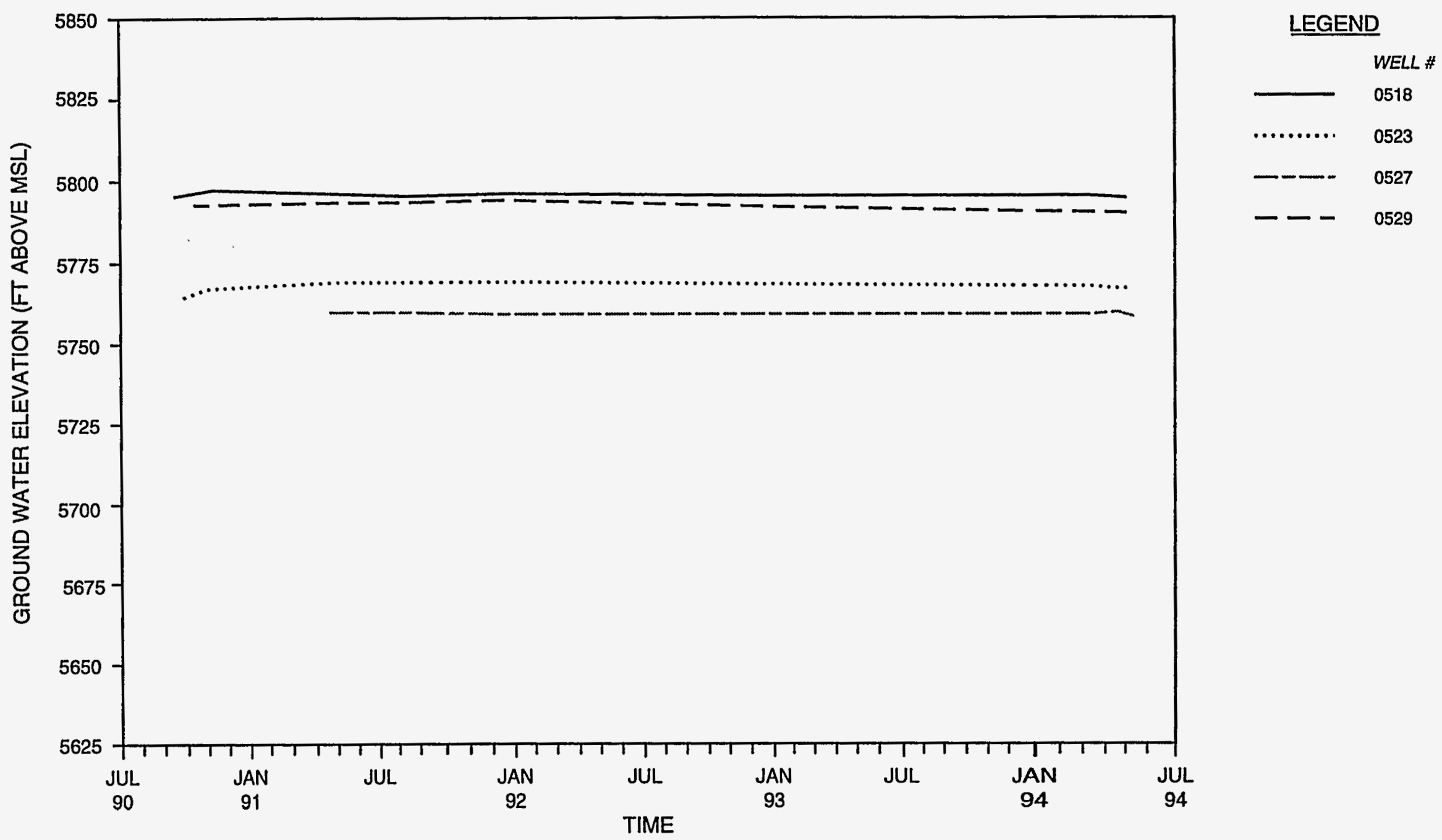

FIGURE 3.17 GROUND WATER HYDROGRAPH OF THE BURRO CANYON UPPER SANDSTONE UNIT BURRO CANYON DISPOSAL SITE NEAR SLICK ROCK, COLORADO 


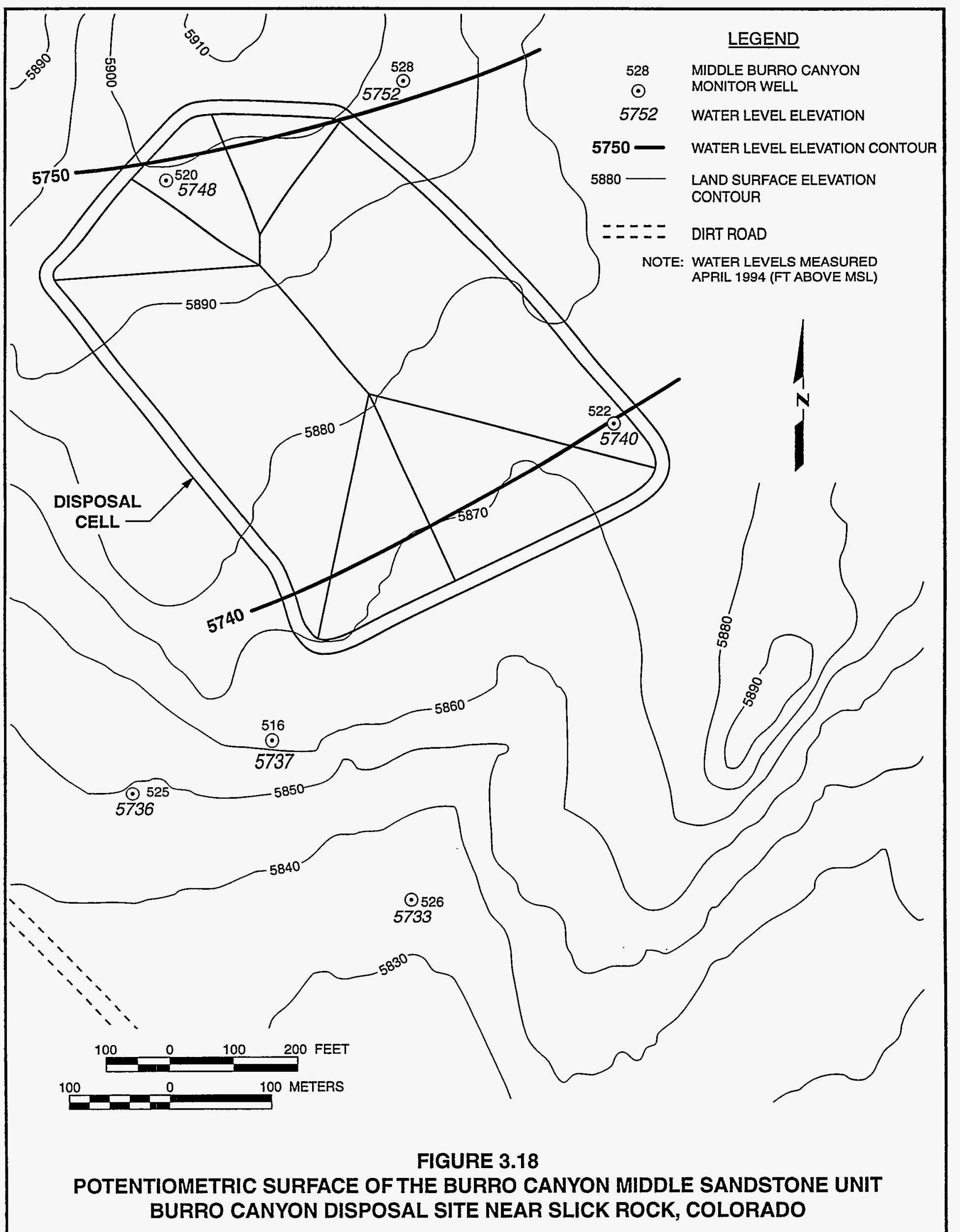




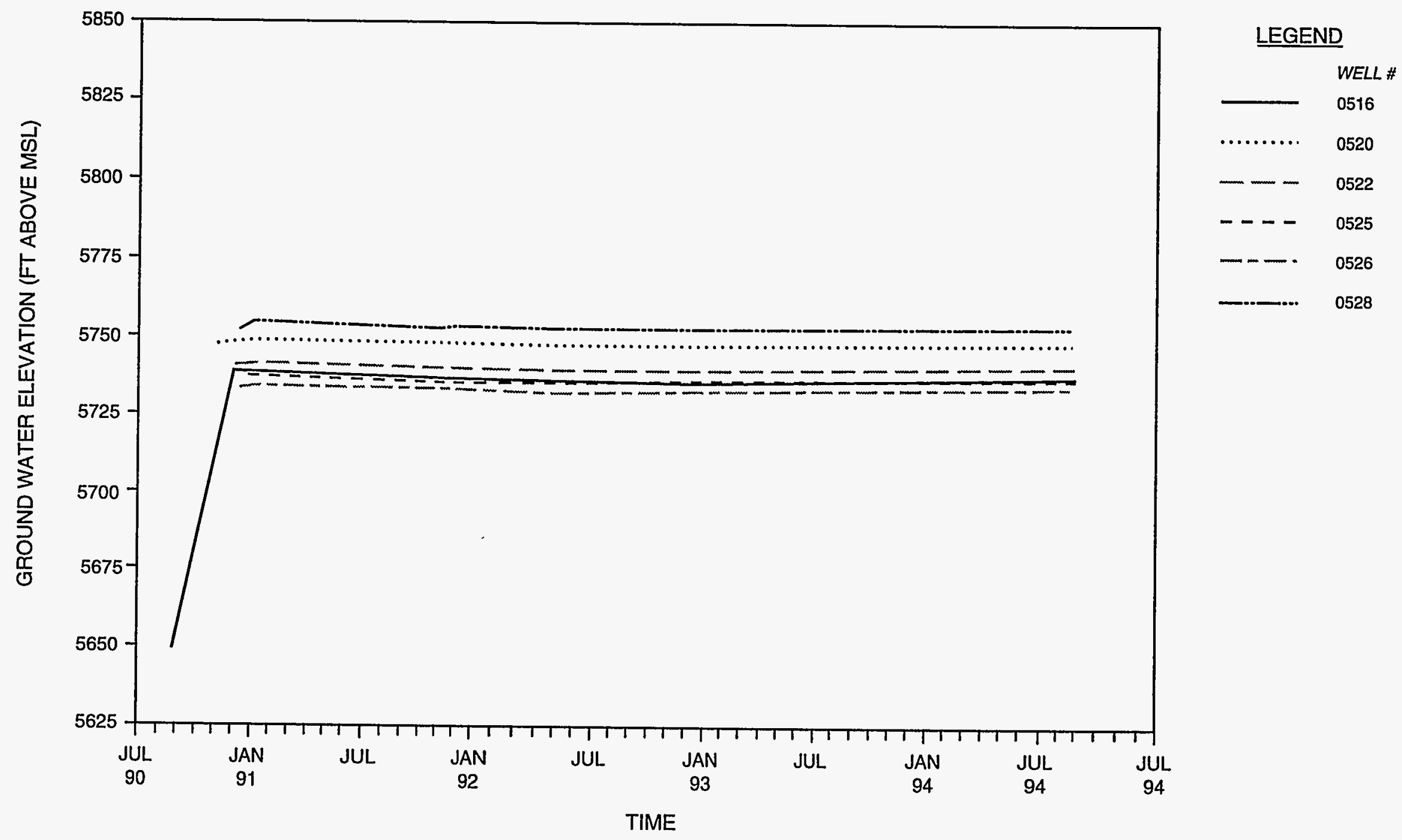

FIGURE 3.19

GROUND WATER HYDROGRAPH OF THE BURRO CANYON MIDDLE SANDSTONE UNIT BURRO CANYON DISPOSAL SITE NEAR SLICK ROCK, COLORADO 


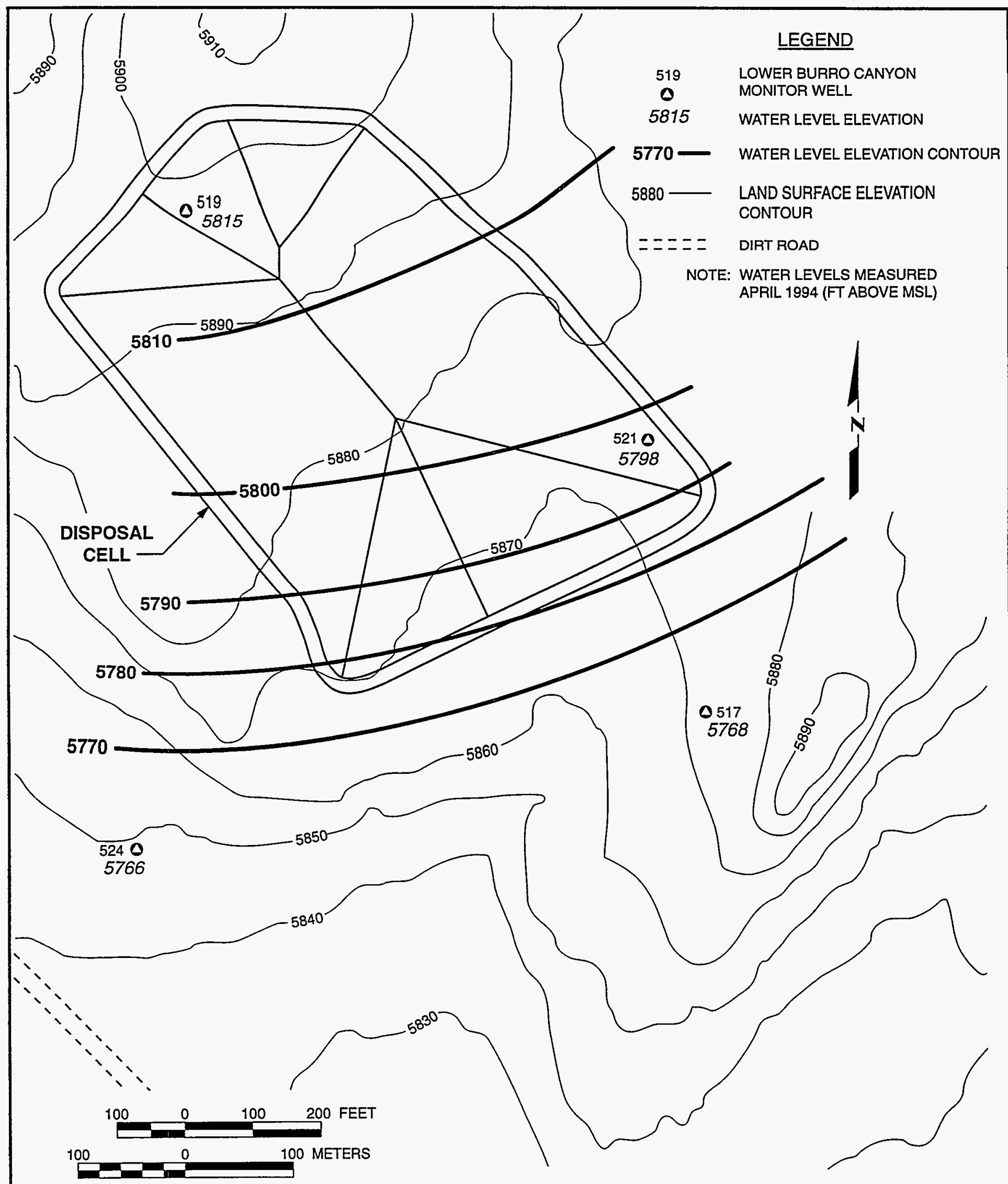

FIGURE 3.20

POTENTIOMETRIC SURFACE OF THE BURRO CANYON LOWER SANDSTONE UNIT BURRO CANYON DISPOSAL SITE NEAR SLICK ROCK, COLORADO 


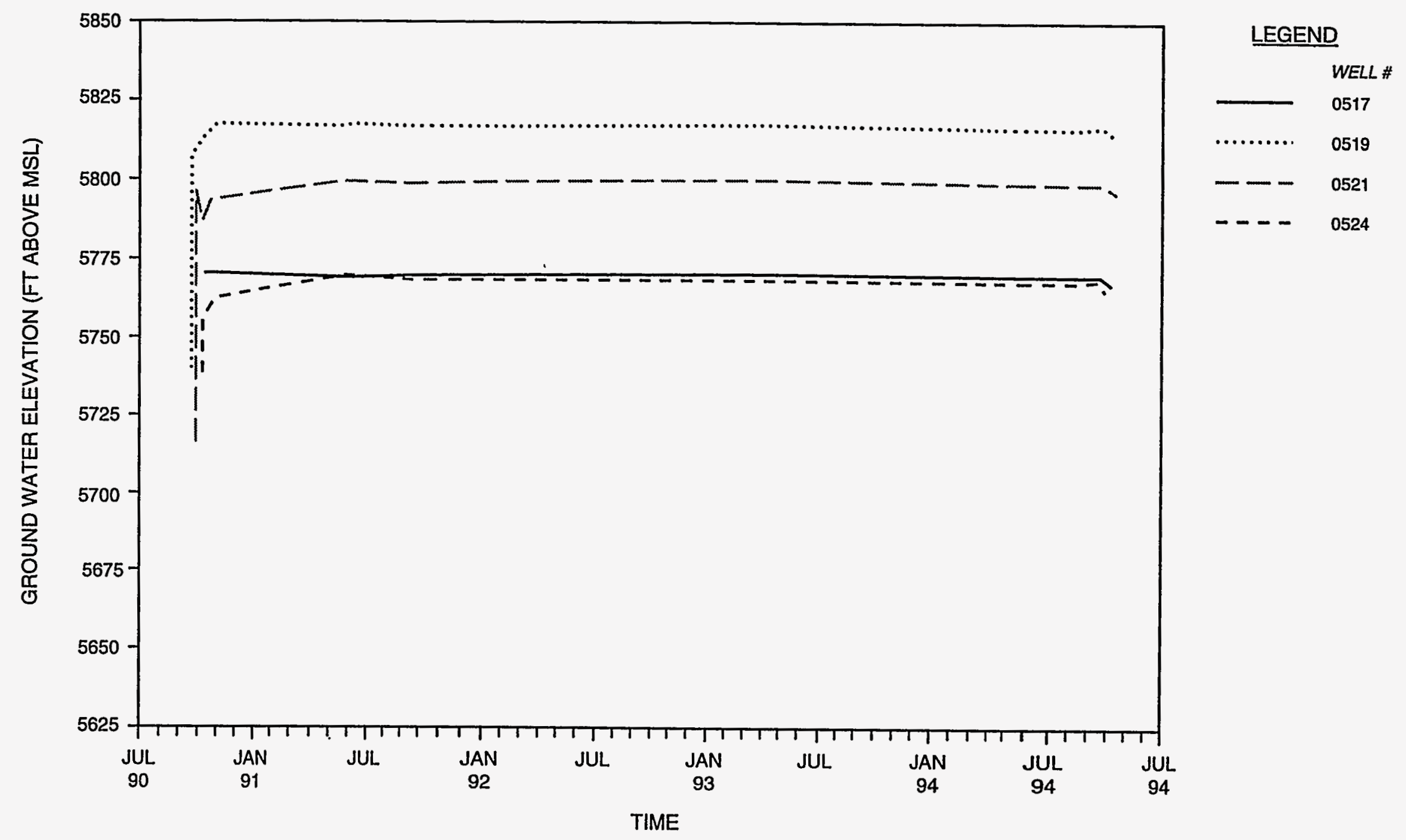

FIGURE 3.21

GROUND WATER HYDROGRAPH OF THE BURRO CANYON LOWER SANDSTONE UNIT BURRO CANYON DISPOSAL SITE NEAR SLICK ROCK, COLORADO 
recharge to and discharge from the lower sandstone unit is restricted because the low-permeability interbedded claystone and siltstone strata impede infiltration.

\subsubsection{Hydraulic characteristics}

Table 3.44 of Appendix A presents the average aquifer parameters and average linear ground water velocities in each water-bearing unit of the Burro Canyon Formation. Calculations of average hydraulic gradients and average ground water velocities are presented in Calculation No. SRK-05-93-14-06-00 in Appendix $C$. Analyses for aquifer performance and slug tests are presented in Calculation No. SRK-06-91-14-03-00 in Appendix C.

\section{Unsaturated Dakota Sandstone and Burro Canyon Formations}

The hydraulic conductivity of the unsaturated Dakota Sandstone bedrock and unsaturated Burro Canyon Formation mudstones was determined by field packer tests. Sixteen packer tests were conducted in three core holes at selected depths to measure the hydraulic conductivity of the bedrock. The tests were analyzed using the approach outlined in the U.S. Bureau of Reclamation's Earth Manual (USBR, 1974), and the results are summarized in Table 3.44 of Appendix A. The average horizontal hydraulic conductivity of the lower Dakota Sandstone Formation was $4 \times 10^{-1} \mathrm{ft} /$ day $\left(1 \times 10^{-4} \mathrm{~cm} / \mathrm{s}\right)$, and the average horizontal hydraulic conductivity of the mudstones in the Burro Canyon Formation was estimated to be $6 \times 10^{-3} \mathrm{ft} / \mathrm{day}\left(2 \times 10^{-6} \mathrm{~cm} / \mathrm{s}\right)$. Packer tests indicate that the saturated horizontal hydraulic conductivity of the sandstone in the Dakota Sandstone is moderate, and is several orders of magnitude greater than that of the Burro Canyon Formation. In addition, the hydraulic conductivity decreases with depth in the Burro Canyon mudstone, reflecting decreased fracture permeability with depth.

\section{Burro Canyon upper sandstone unit}

To determine the hydraulic properties of the upper sandstone unit, low-yield aquifer performance pumping tests were conducted on monitor wells 523 and 529; bailer recovery tests were conducted on monitor wells 518 and 527 . Monitor well 523 was pumped at an average rate of 0.13 gallons per minute (gpm) (the lowest possible pumping rate to approximate $150 \mathrm{gpd}$ ) $\left(8.2 \times 10^{-3} \mathrm{~L} / \mathrm{s}\right)$ for 39 hours. Substantial drawdown $(61$ percent of the available drawdown) occurred during the aquifer performance pumping test. The pumping rate was increased to $0.5 \mathrm{gpm}\left(3.2 \times 10^{-2} \mathrm{~L} / \mathrm{s}\right)$ to determine if the well could support a higher pumping rate; however, the well went dry. In a second pumping test, monitor well 529 was pumped at a rate of $0.13 \mathrm{gpm}$ $\left(8.2 \times 10^{-3} \mathrm{~L} / \mathrm{s}\right)$, and went dry within 2 hours. During both pumping tests, no response was observed in nearby monitor wells completed in the upper and middle sandstone units. Bailer recovery tests conducted on the upper sandstone unit indicated that the transmissivity ranges from $0.02 \mathrm{ft}^{2} /$ day to $1.04 \mathrm{ft}^{2} /$ day $\left(2.2 \times 10^{-8}\right.$ square meters $\left[\mathrm{m}^{2}\right] / \mathrm{s}$ to $\left.1.1 \times 10^{-6} \mathrm{~m}^{2} / \mathrm{s}\right)$, and averages $0.16 \mathrm{ft}^{2} /$ day $\left(1.7 \times 10^{-7} \mathrm{~m}^{2} / \mathrm{s}\right)$. However, borehole storage effects are believed 
to be significant and the aquifer may not have been stressed. The average hydraulic conductivity of the upper sandstone unit is $4 \times 10^{-2} \mathrm{ft} /$ day $\left(1 \times 10^{-5}\right.$ $\mathrm{cm} / \mathrm{s})$. The results of these tests are presented in Calculation No. SRK-06-19-14-03-00 in Appendix C, using the analytical Well Hydraulics Interpretation Program (WHIP).

Darcy's Law was used to calculate the average linear ground water velocity in the upper sandstone unit of the Burro Canyon Formation (Calculation No. SRK-05-93-14-06-00, Appendix C). The average linear ground water velocity in the upper sandstone unit was estimated to be $6 \mathrm{ft} /$ year $\left(6 \times 10^{-6} \mathrm{~cm} / \mathrm{s}\right)$ (Table 3.44 of Appendix A), based on an average hydraulic conductivity of $4 x$ $10^{-2} \mathrm{ft} /$ day $\left(1 \times 10^{-5} \mathrm{~cm} / \mathrm{s}\right)$, a hydraulic gradient of 0.04 , and an effective porosity of 0.10 (Freeze and Cherry, 1979).

The upper sandstone unit has a low transmissivity and an average saturated thickness of $12 \mathrm{ft}(4 \mathrm{~m})$. Drawdown for a hypothetical well completed in the upper sandstone was calculated using an analytical solution of the Theis nonequilibrium well equation. Using a transmissivitiy of $0.8 \mathrm{ft}^{2}$ per day, a storage coefficient of 0.1 , and a well yield of $150 \mathrm{gpd}\left(6.6 \times 10^{-3} \mathrm{~L} / \mathrm{s}\right)$, a drawdown of $21.4 \mathrm{ft}(6.5 \mathrm{~m})$ was calculated for the hypothetical well (Calculation No. SRK-11-94-14-09-00). The calculated drawdown exceeds the maximum observed saturated thickness of $18.9 \mathrm{ft}(5.8 \mathrm{~m})$ in the upper sandstone unit and suggests that this unit cannot sustain a minimum well vield of $150 \mathrm{gpd}\left(6.6 \times 10^{-3} \mathrm{~L} / \mathrm{s}\right)$. The results of the aquifer performance tests and the analytical calculation demonstrate that the uppermost aquifer at the disposal site cannot provide a sustained yield of $150 \mathrm{gpd}\left(6.6 \times 10^{-3} \mathrm{~L} / \mathrm{s}\right)$ because 1) only one out of four wells (the one with the greatest saturated thickness) could sustain a similar pumping rate for over 24 hours; 2) when pumped at the same rate, a well with a saturated thickness of $15 \mathrm{ft}(4.6 \mathrm{~m})$ went dry in less than 2 hours; 3 ) the average saturated thickness of the upper sandstone unit is only $12 \mathrm{ft}(3.7 \mathrm{~m}) ; 4)$ the upper sandstone unit of the Burro Canyon Formation is present only as a cap at the top of the Joe Davis Canyon; and 5) there is no evidence of springs or seeps where the upper sandstone unit crop out. Because of the demonstrated low yield from the aquifer (less than $150 \mathrm{gpd}$ ), ground water is classified as limited use, in accordance with 40 CFR $\$ 192.11(e)$ of the final EPA ground water standards. As a result of the limited quantity of water available, the upper sandstone unit (uppermost aquifer) is not, and never can be, a viable source of water.

\section{Burro Canyon middle sandstone unit}

To determine the aquifer parameters of the middle unit and the degree of hydraulic connection with the upper and lower units, a 72-hour pumping test was conducted on monitor well 522; drawdown and recovery were observed in all six other monitor wells completed in the middle unit. Monitor well 522 was pumped at an average rate of $0.5 \mathrm{gpm}\left(3 \times 10^{-2} \mathrm{~L} / \mathrm{s}\right)$ for the entire duration of the test; a preliminary step test indicated the well could not support a pumping rate of $1 \mathrm{gpm}\left(6 \times 10^{-2} \mathrm{~L} / \mathrm{s}\right)$ because of excessive drawdown. 
The pumping and recovery tests on the middle unit indicated that the transmissivity of the aquifer ranges from 5 to $7 \mathrm{ft}^{2} /$ day $\left(5\right.$ to $\left.7 \times 10^{-6} \mathrm{~m}^{2} / \mathrm{s}\right)$, and averages $6 \mathrm{ft}^{2} /$ day $\left(6 \times 10^{-6} \mathrm{~m}^{2} / \mathrm{s}\right)$ (Table 3.44 of Appendix A). During the 72-hour test, responses were noted in five observation wells screened in the middle sandstone unit. However, no responses were observed in the upper or lower water-bearing units.

The average hydraulic conductivity of the middle sandstone unit is $9 \times 10^{-2} \mathrm{ft} /$ day $\left(3 \times 10^{-5} \mathrm{~cm} / \mathrm{s}\right)$, assuming an average saturated thickness of $65 \mathrm{ft}(20 \mathrm{~m})$. The average linear ground water velocity in the middle sandstone unit is $2 \mathrm{ft} /$ year $\left(2 \times 10^{-6} \mathrm{~cm} / \mathrm{s}\right)$ (Table 3.44 of Appendix $\left.A\right)$, assuming an average hydraulic conductivity of $9 \times 10^{-2} \mathrm{ft} /$ day $\left(3 \times 10^{-5} \mathrm{~cm} / \mathrm{s}\right)$, a hydraulic gradient of 0.02 , and an effective porosity of 0.20 (Freeze and Cherry, 1979).

The confined conditions in this unit cause a substantial upward hydraulic potential. The potentiometric surface of the middle unit averages $42 \mathrm{ft}(13 \mathrm{~m})$ above the top of the sandstone unit. This potentiometric surface, however, is not higher in elevation than the overlying potentiometric surface measured in monitor wells screened in the upper sandstone unit. Calculations are documented in Appendix $C$ (Calculations No. SRK-06-91-14-03-00 and No. SRK-05-93-14-06-00).

\section{Burro Canyon lower sandstone unit}

Slug injection tests conducted on monitor wells 519, 521, and 524 completed in the lower sandstone unit indicate that the unit transmissivity averages $0.1 \mathrm{ft}^{2} /$ day $\left(1 \times 10^{-7} \mathrm{~m}^{2} / \mathrm{s}\right)$ (Table 3.44 of Appendix A). However, borehole effects are likely to be significant. As a result, transmissivity values may be biased by borehole stage effects. The average hydraulic conductivity of the lowermost unit is $5 \times 10^{-3} \mathrm{ft} /$ day $\left(2 \times 10^{-6} \mathrm{~cm} / \mathrm{s}\right)$. The average linear ground water velocity in the lower sandstone unit is $1 \mathrm{ft} /$ year $\left(1 \times 10^{-6} \mathrm{~cm} / \mathrm{s}\right)$, assuming a hydraulic conductivity of $5 \times 10^{-3} \mathrm{ft} /$ day $\left(2 \times 10^{-6} \mathrm{~cm} / \mathrm{s}\right)$, a gradient of 0.06 , and an effective porosity of 0.10 (Table 3.44 of Appendix A). Calculations are documented in Appendix $C$ (Calculations No. SRK-05-93-14-06-00 and No. SRK-06-91-14-03-00).

\subsubsection{Background ground water quality}

Background ground water quality in each hydrostratigraphic unit within the Burro Canyon Formation was determined from analyses of ground water from monitor wells completed in each unit. Ground water quality data were characterized individually for each hydrostratigraphic unit because the units are hydrogeologically separated (Calculation No. SRK-05-93-12-10-00 in Appendix Cl.

In general, ground water $\mathrm{pH}$ is near-neutral, and TDS concentrations tend to decrease with depth. The average TDS concentration is $761 \mathrm{mg} / \mathrm{L}$ in the upper sandstone unit, $555 \mathrm{mg} / \mathrm{L}$ in the middle sandstone unit, and $345 \mathrm{mg} / \mathrm{L}$ in the lower sandstone unit. 


\section{Burro Canyon upper sandstone unit}

Six background ground water monitor wells are screened and filter packed into the upper sandstone unit of the Burro Canyon Formation. These monitor wells are identified as $518,523,527,529,551$, and 552 in Figure 3.16. Ground water quality data by parameter are provided in Table 3.45 of Appendix A. Ground water quality statistics are provided in Table 3.46 and summarized in Table 3.47 of Appendix A.

Ground waters in this unit are sodium sulfate and sodium bicarbonate types. TDS concentrations range from $556 \mathrm{mg} / \mathrm{L}$ to $973 \mathrm{mg} / \mathrm{L}$. Ground water in the upper sandstone unit is neutral to slightly alkaline with $\mathrm{pH}$ ranging from 7.5 to 9.1 .

As shown in Table 3.48 of Appendix A, the activity of Ra-226 and -228 has equaled or slightly exceeded its MCL on one occasion in samples collected from monitor wells 518 and 529. In addition, the concentration of selenium consistently exceeds the MCLs in ground water samples collected from monitor well 518.

\section{Burro Canyon middle sandstone unit}

Six background ground water monitor wells are screened and filter packed into the middle sandstone unit of the Burro Canyon Formation. These monitor wells are identified as $516,520,522,525,526$, and 528 in Figure 3.18. Ground water quality data by parameter are provided in Table 3.49 of Appendix A. Ground water quality statistics are provided in Table 3.50 of Appendix A.

Monitor wells screened in the middle sandstone unit produce ground waters that are characterized as sodium bicarbonate and sodium sulfate types; the $\mathrm{pH}$ ranges from 7.2 to 7.6. TDS concentrations range from 422 to $696 \mathrm{mg} / \mathrm{L}$. The activity of Ra-226 and -228 slightly exceeded its $\mathrm{MCL}$ in one well (516) in a one-time occurrence (Table 3.51 of Appendix A).

\section{Burro Canyon lower sandstone unit}

Four background ground water monitor wells are screened and filter packed into the lower sandstone unit of the Burro Canyon Formation. These monitor wells are identified as 517, 519, 521, and 524 in Figure 3.20. Ground water quality data by parameter are provided in Table 3.52 of Appendix A. Ground water quality statistics are provided in Table 3.53 of Appendix A.

Ground water samples collected from monitor wells screened in the lower sandstone unit are of the sodium bicarbonate type. TDS concentrations range from $256 \mathrm{mg} / \mathrm{L}$ to $485 \mathrm{mg} / \mathrm{L}$. The ground water of the lower sandstone unit is slightly alkaline, with pH ranging from 8.6 to 9.6. All water quality samples collected from monitor wells screened in the lower unit have been below the MCLs for all regulated constituents. 


\section{Geochemical conditions}

Favorable geochemical conditions appear to be present at the Burro Canyon disposal site for attenuation of most hazardous constituents present in the tailings pore fluid. This assessment is based on chemical analyses of the drill cuttings and cores (including chemical analyses, polarized light microscopy with modal analyses, screen analyses, and $X$-ray diffraction), ground water quality analyses, examination of the stratigraphic section of the geologic materials underlying the disposal site, and preliminary laboratory experiments.

Geochemical conditions that control the transport of the hazardous constituents from the tailings into ground water and by ground water within the aquifers at the disposal site are essentially the same as the conditions controlling transport at the processing site. These conditions include 1) the ground water chemical composition, $\mathrm{pH}$, and Eh of the tailings pore fluid, soil pore fluid, and ground water; and 2) the reactive mineralogy of the subsoils and aquifer materials. The chemical compositions, $\mathrm{pH}$, and Eh of the various fluids determine the types of precipitation/coprecipitation reactions that can occur to control the migration rate of contaminants of concern. The chemical compositions, $\mathrm{pH}$, and Eh of the fluids combined with the reactive mineralogy of the subsoils and aquifer materials determine the sorts of adsorption reactions that can involve contaminants of concern.

Precipitation and coprecipitation reactions can result from acid-neutralization reactions, a general condition of oversaturation in the tailings seepage, and oxidation-reduction reactions. The acid-neutralization reactions occur as a result of the tailings leachate seepage into subsurface units that contain carbonates and other acid-neutralizing phases. Neutralization of acid leachate causes the precipitation of alkali earth and transition metals originally in the leachate. Because the tailings fluids at the $U C$ and $N C$ sites are near-neutral in $\mathrm{pH}(6.2$ to 7.8), acid-neutralization reactions will not be a major retardation mechanism for the contaminants of concern at the processing site. However, even if acid conditions were present, the high calcite content (36 tons $\mathrm{CaCO}_{3} / 1000$ tons soil) of the Burro Canyon shale beneath the cell (PMET, 1990) would neutralize the acid.

The tailings pore fluids are generally oversaturated in gypsum, calcite, quartz, and, locally, in other solid phases. Although such oversaturation eventually leads to precipitation, the precipitation reactions are commonly slow to occur. In general, quartz precipitation rates are much slower than gypsum rates at the same level of oversaturation; therefore, gypsum tends to precipitate from oversaturated solutions before quartz. As these phases precipitate in the pore spaces in the tailings within the cell or in the rock units beneath the cell, some trace contaminants of concern may coprecipitate depending on the saturation level of the contaminant species. For example, radium could precipitate with gypsum or barite and cadmium and zinc could coprecipitate with calcite.

The oxidation-reduction induced precipitation reactions are probably the most important class of precipitation reactions at the disposal and processing sites for 
the same reasons. The Eh and several related parameters were measured with a platinum probe in most wells screened in the middle and lower sandstone units at the Burro Canyon disposal site. Wells in the upper sandstone unit did not yield sufficient quantities of water to allow measurement of Eh or related parameters. In general, wells screened in the lower sandstone unit had relatively high Eh values $(400 \mathrm{mV})$ indicative of oxidizing conditions. Wells in the middle sandstone unit showed a range in Eh from 200 to $400 \mathrm{mV}$. Beneath the footprint of the cell, the values ranged from 200 to $330 \mathrm{mV}$ with a average value of $250 \mathrm{mV}$. This value is not sufficiently reducing to convert sulfate to sulfide or $U^{+6}$ to $U^{+4}$. However, it would result in ammonium being the dominant nitrogen species and native selenium being the dominant form of selenium. Ammonium and native selenium are less mobile than their corresponding oxidized forms. The Burro Canyon mudstone unit directly beneath the cell contains finely disseminated pyrite that may locally provide sufficiently reducing conditions to convert $U^{+6}$ to $U^{+4}$, at least on the pyrite grain surfaces.

Adsorption reactions involve the attachment of simple and complex ions to the exterior surfaces of minerals and/or ion exchange on interior exchange sites in ion-exchanging minerals. Although the details of the surface attachment reactions are not completely known, it is well known that surfaces of iron and manganese oxides and oxyhydroxides have high affinities for transition metals and oxyanions at neutral to somewhat acidic conditions. However, the metals and oxyanions do not all have the same affinity for these oxides and oxyhydroxides. On the basis of theoretical derivations, the relative affinities cannot be reliably predicted in complex natural systems such as the ground water systems associated with uranium mill tailings sites. These relative affinities must be measured in a laboratory by either batch or column experiments.

Ion exchange reactions involving cations are better understood. The (cation) ion exchange capacities of the upper Burro Canyon Formation mudstone are relatively high (15 to 16 milliequivalents [meq]/100 grams) with the ion exchange capacity of the upper sandstone unit being somewhat lower at 6.6 meq/100 grams. These data suggest a significant exchange capacity exists in the units directly beneath the disposal cell. Results from three point sorption batch experiments performed with synthetic leachate spiked with cadmium, molybdenum, selenium, and uranium and Burro Canyon Formation fine-grained material were used to calculate partitioning coefficients $\left(K_{d}\right)$, contaminantspecific retardation velocities, and travel times through the subsurface. Partitioning coefficient values for more mobile constituents such as chloride, sulfate, and nitrate have also been derived. These data provide information about migration of cations and anionic species, including oxyanions of redoxsensitive elements (i.e., sulfate, selenate, and molybdate) in the environment beneath the disposal cell.

Furthermore, results from composite column tests constructed to reflect the stratigraphy beneath the site have also been evaluated. Although equilibrium conditions were never attained in the columns, this information provides 
valuable insight into predicting the transport and behavior of individual contaminants in the subsurface.

In summary, the Burro Canyon Formation in the vicinity of the disposal site has been adequately characterized with respect to the attenuation potential of constituents germane to uranium mill tailings leachate. Distribution coefficients $\left(K_{d}\right)$ for select contaminants, including cadmium $\left(K_{d}=800 \mathrm{~mL} / \mathrm{g}\right)$, molybdenum $\left(K_{d}=0.7 \mathrm{~mL} / \mathrm{g}\right)$, selenium $\left(K_{d}=2 \mathrm{~mL} / \mathrm{g}\right)$, and uranium $\left(K_{d}=\right.$ approximately $0.5 \mathrm{~mL} / \mathrm{g})$, indicate that attenuation will occur as tailings leachate migrates beneath the disposal cell. Therefore, because of the relatively high $K_{d}$ values and the presence of $60 \mathrm{ft}(18 \mathrm{~m})$ of low-permeability Burro Canyon Formation mudstone between the base of the cell and the first water-bearing unit, it is unlikely that leachate will adversely affect ground water beneath the disposal cell.

\subsubsection{Ground water use, value, and alternative supplies}

No known registered wells or private wells are actively used within the upper sandstone unit of the Burro Canyon Formation within a $2-\mathrm{mi}(3-\mathrm{km})$ radius of the Burro Canyon disposal site.

Ground water development in the vicinity of the disposal site should not increase over the next $\mathbf{5 0}$ years. The first hydrostratigraphic zone of saturation has a low yield (less than $150 \mathrm{gpd}$ ), and is therefore classified as limited use in accordance with 40 CFR $\$ 192.11(\mathrm{e})$ of the final EPA ground water protection standards. By definition, limited use ground water is not a current or potential source of drinking water. No development is planned adjacent to the Burro Canyon disposal site. Population projections for San Miguel County (Novosad, 1994 ) estimate a 60 percent increase (3682 to 6333 people) in population from 1995 to 2020 . There is no indication about where this increase would occur, but it is reasonable to expect that the largest increase would take place in and around existing population centers (e.g., Telluride). The Burro Canyon disposal site is in a remote location, and the public lands at and around the disposal site are administered by the BLM primarily for livestock grazing. Therefore, it is doubtful that any substantial population increase and corresponding increase in ground water use would occur at or in the vicinity of the disposal site. 


\subsection{REFERENCES}

Cooley et al. (M. E. Cooley, J. W. Hershbarger, J. P. Akers, and W. E. Hardt), 1969. "Regional Hydrogeology of the Navajo and Hopi Indian Reservations, Arizona, New Mexico, and Utah," U.S. Geological Survey Professional Paper 521-A, Washington, D.C.

Daniel B. Stephens \& Associates, Inc., 1991. Laboratory Analysis of Soil Hydraulic Properties of the Burro Canyon Rock Samples, prepared for the U.S. Department of Energy, UMTRA Project Office, Albuquerque Operations Office, Albuquerque, New Mexico.

DOE (U.S. Department of Energy), 1992. Software Program for Environmental Analysis and Reporting (SPEAR) System, U.S. Department of Energy, UMTRA Project Office, Albuquerque Operations Office, Albuquerque, New Mexico.

DOE (U.S. Department of Energy), 1989. Technical Approach Document, UMTRA-DOE/AL-050425.0002, U.S. Department of Energy, UMTRA Project Office, Albuquerque Operations Office, Albuquerque, New Mexico.

DOE (U.S. Department of Energy), 1986. Comparative Analysis of Disposal Site Alternatives Report for the UMTRA Project Slick Rock Sites Located at Slick Rock, Colorado, U.S. Department of Energy, UMTRA Project Office, Albuquerque Operations Office, Albuquerque, New Mexico.

EPA (U.S. Environmental Protection Agency), 1989. Statistical Analysis of Ground-Water Monitoring Data at RCRA Facilities-Interim Final Guidance, EPA/530-SW-89026.

FBDU (Ford, Bacon \& Davis Utah Inc.), 1981. Engineering Assessment of Inactive Uranium Mill Tailings, Slick Rock Sites, Slick Rock, Colorado, DOE/UMT-0115, FBDU 360-07, UC 70, prepared by FBDU, Salt Lake City, Utah, for the U.S. Department of Energy, UMTRA Project Office, Albuquerque Operations Office, Albuquerque, New Mexico.

FBDU (Ford, Bacon \& Davis Utah Inc.), 1977. Engineering Assessment of the Inactive Uranium Mill Tailings, Slick Rock, Colorado, DOE/UMT-0115, prepared by FBDU, Salt Lake City, Utah, for the U.S. Department of Energy, Albuquerque Operations Office, Albuquerque, New Mexico.

Freeze, R. A., and J. A. Cherry, 1979. Ground Water, Prentice-Hall, Inc., Englewood Cliffs, New Jersey.

Merritt, R. C., 1971. The Extractive Metallurgy of Uranium, Colorado School of Mines Research Center, Golden, Colorado. 
Novosad, C., 1994. State of Colorado, Department of Local Affairs, Division of Local Government, Denver, Colorado, personal communication to M. Gawthrop, Jacobs Engineering Group Inc., UPDCC File Location No. 11.16.0, Albuquerque, New Mexico, August 16, 1994.

PMET (Pittsburgh Mineral \& Environmental Technology, Inc.), 1990. Chemical and Mineralogical Characterization of Soil Samples from Slick Rock, Colorado (Burro Canyon), prepared by Wolfgang Baum of PMET for Jacobs Engineering Group Inc., Albuquerque Operations Office, Albuquerque, New Mexico.

Shawe et al. (D. R. Shawe, G. C. Simmons, and N. L. Archibold), 1968. Stratigraphy of Slick Rock District and Vicinity, San Miguel and Dolores Counties, Colorado, U.S. Geological Survey Professional Paper 576-A, Washington, D.C.

USBR (U.S. Bureau of Reclamation), 1974. Earth Manual, second edition, Denver, Colorado.

\section{CODE OF FEDERAL REGULATIONS}

40 CFR Part 61, National Emission Standards for Hazardous Air Pollutants, U.S. Environmental Protection Agency.

40 CFR Part 192, Health and Environmental Protection Standards for Uranium and Thorium Mill Tailings, U.S. Environmental Protection Agency.

\section{FEDERAL REGISTER}

60 FR 2854, Groundwater Standards for Remedial Actions at Inactive Uranium Processing Sites; Final Rule, 11 January 1995.

\section{UNITED STATES CODE}

42 USC $\$ 7901$ et seq., Uranium Mill Tailings Radiation Control Act, November 8, 1978. 
ATTACHMENT 4

WATER RESOURCES PROTECTION STRATEGY 


\section{TABLE OF CONTENTS}

Section

Page

1.0 WATER RESOURCES PROTECTION STRATEGY SUMMARY $\ldots \ldots \ldots \ldots$

2.0 CONCEPTUAL DESIGN CONSIDERATIONS AND FEATURES FOR

WATER RESOURCES PROTECTION .................... 2-1

2.1 Design considerations ....................... 2-1

2.1.1 Climate and infiltration ................. 2-1

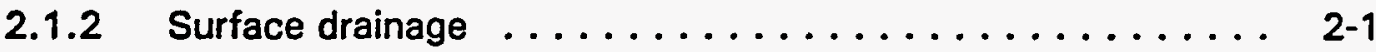

2.1.3 Subsurface drainage .................... $2-2$

2.2 Design features ........................... $2-2$

2.2.1 Disposal cell cover components ................ 2. 2-4

2.2.2 Transient drainage and control of construction water . . . . . 2-4

2.2.3 Subsidence ........................ 2-6

2.2 .4 Disposal cell longevity ................... 2-6

3.0 DISPOSAL AND CONTROL OF RADIOACTIVE MATERIALS AND

NONRADIOACTIVE CONTAMINANTS ................... 3-1

3.1 Ground water protection standard ................... $\ldots \ldots$

3.1.1 Hazardous constituents ................... 3-2

3.1.2 Proposed concentration limits .............. $3-4$

3.1.3 Point of compliance ..................... 3-4

3.2 Narrative supplemental standard .................... $3-5$

3.2.1 Applicability criteria ................... 3-5

3.2.2 Demonstration that remedial action satisfies the proposed supplemental standard .................. 3-6

3.2.3 As low as reasonable under the circumstances ........ 3-6

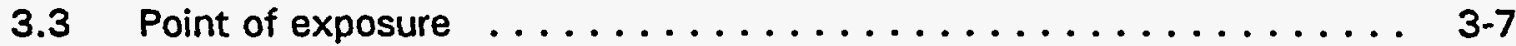

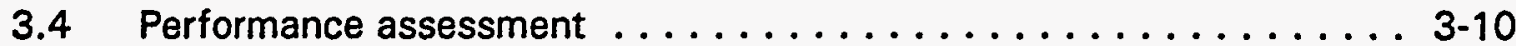

3.5 Closure performance demonstration .................. 3-11

3.6 Ground water monitoring program ................. 3-11

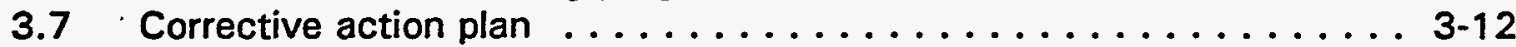

4.0 CLEANUP AND CONTROL OF EXISTING CONTAMINATION $\ldots \ldots \ldots \ldots$

5.0 REFERENCES $\ldots \ldots \ldots \ldots \ldots \ldots \ldots \ldots \ldots \ldots \ldots \ldots \ldots \ldots \ldots \ldots \ldots$ 


\section{LIST OF FIGURES}

Figure

Page

2.1 Disposal cell for Slick Rock tailings near Slick Rock, Colorado . . . . . . . . 2-3

2.2 Cross section of disposal cell, Burro Canyon disposal site near

Slick Rock, Colorado . . . . . . . . . . . . . . . . . . . . . . . . 2-5

3.1 Structural map of upper sandstone unit of Burro Canyon Formation . . . . . 3-8

3.2 Representative diagrammatic section of strata, Burro Canyon Formation ..... 3-9

\section{LIST OF TABLES}

Table

Page

3.1 Summary of hazardous constituents, Slick Rock, Colorado, sites . . . . . . 3-3 


\section{LIST OF ACRONYMS}

Acronvm

DOE

EPA

$\mathrm{MCL}$

NC

NEPA

NRC

POC

RAP

RRM

TAC

UC

UMTRA

\section{Definition}

U.S. Department of Energy

U.S. Environmental Protection Agency maximum concentration limit North Continent National Environmental Policy Act U.S. Nuclear Regulatory Commission point of compliance remedial action plan residual radioactive material Technical Assistance Contractor Union Carbide

Uranium Mill Tailings Remedial Action 


\subsection{WATER RESOURCES PROTECTION STRATEGY SUMMARY}

To achieve compliance with the U.S. Environmental Protection Agency (EPA) ground water protection standards (Subpart A of 40 CFR Part 192), the U.S. Department of Energy (DOE) proposes to apply supplemental standards for limited use ground water. Supplemental standards are appropriate due to the low yield (less than 150 gallons per day [gpd]) $\left(6.6 \times 10^{-3}\right.$ liters per second [L/s]) in the uppermost aquifer (upper sandstone unit of the Burro Canyon Formation). Ground water in this aquifer is not a current nor potential source of drinking water because of the low yield. Therefore, this remedial action will ensure protection of human health and the environment. The principal features of the water resources protection strategy for the Burro Canyon disposal site are summarized below.

- Uranium tailings and associated contaminated materials at the Union Carbide (UC) and North Continent (NC) processing sites will be consolidated and relocated to the Burro Canyon disposal site. These materials will be placed in a partially below-grade disposal cell designed to reduce radon emanation, resist degradation, reduce infiltration, and withstand differential settlement.

- The locations of the site and the disposal cell foundation optimize the site's favorable hydrogeologic and geochemical conditions, as will the multiple-component cover. The design for the disposal embankment cover consists of the following layers, in descending order from the top: 1) riprap to prevent disposal cell erosion by surface water runoff; 2) a sand and gravel bedding layer to prevent displacement of large-diameter rock, protect the underlying frost protection layer from erosion, and drain water laterally; 3) a frost protection layer (fine-grained soil with some sand) to protect the radon/infiltration barrier from the effects of freezing and thawing; and 4) a thick sandy clay radon barrier to inhibit radon emanation and infiltration through the underlying contaminated material.

- The proposed ground water protection compliance strategy applies supplemental standards. Based on aquifer performance (pumping tests), the demonstrated quantity of water available from the uppermost aquifer is less than $150 \mathrm{gpd}\left(6.6 \times 10^{-3} \mathrm{~L} / \mathrm{s}\right)$, and ground water is classified as limited use because it is neither a current nor a potential source of drinking water.

- Ground water in lithologic units underlying the upper sandstone unit of the Burro Canyon Formation (uppermost aquifer) is protected from potential site-related contamination by hydrogeologic isolation. Low-permeability mudstone units and steady-state upward vertical hydraulic gradients in the lower and middle sandstone units of the Burro Canyon Formation inhibit downward migration of water.

Demonstration of cleanup and control of existing processing-related ground water contamination at the UC and NC sites will be addressed under a separate DOE Uranium Mill Tailings Remedial Action (UMTRA) Project, which will include compliance with the National Environmental Policy Act (NEPA). The proposed surface remedial action will not preclude or interfere with active ground water restoration at the processing site, should it be required, because the tailings will be relocated to a remote disposal site. 


\subsection{CONCEPTUAL DESIGN CONSIDERATIONS AND FEATURES FOR WATER RESOURCES PROTECTION}

\section{$2.1 \quad$ DESIGN CONSIDERATIONS}

\subsubsection{Climate and infiltration}

Climate is an important design consideration. It influences the quantity of water available to percolate through the cover of the disposal cell and through stabilized residual radioactive materials (RRM), and it has a potential effect on the migration of hazardous constituents to ground water.

The Burro Canyon site has an arid, continental climate with low precipitation and humidity, large temperature variations, and high evaporation (DOE, 1994). Because of the high plateau of the Dolores anticline immediately overlooking the UC, NC, and Burro Canyon sites from the south and east, the climate is typically drier and warmer than the nearby communities of Egnar, Dove Creek, Monticello, and Cortez that lie on this plateau (Shawe et al., 1968).

High-intensity thunderstorms occur in the Slick Rock area. In the past, these storms have eroded the tailings piles at the UC and NC sites (DOE, 1994). The average annual precipitation is 7 to 10 inches (180 to 250 millimeters [mm]) per year. Thunderstorm activity and precipitation are greatest during August and September. The average wind speed in the Slick Rock area is estimated to be 3.4 miles (mi) (5.5 kilometers [km]) per hour (FBDU, 1981).

\subsubsection{Surface drainage}

The relation of surface topography to disposal cell location and final grading should enhance the ability of the proposed design to divert surface flow around the disposal cell (thereby limiting the quantity of water available for infiltration) by shedding surface flow from the disposal cell.

The average elevation of the Burro Canyon disposal site is 5900 feet ( $\mathrm{ft}$ ) (1800 meters [m]) above mean sea level. The disposal site is on a small mesa that is completely isolated from upland drainages runoff. The drainage north and east of the site is the Nicholas Wash Basin. The disposal site and basins south of the site drain into Joe Davis Canyon. Runoff in the two shallow drainages in the center of the site (which is on the mesa) drains by sheet flow until it reaches the south edge of the mesa. There the flow concentrates into a well-defined gully that incises the rim. Flooding is not considered a hazard at the Burro Canyon disposal site because of its distance from, and elevation above, the closest stream channel. 


\subsubsection{Subsurface drainage}

The ability of the disposal cell foundation to accept transient drainage of excess moisture from the tailings without adversely impacting ground water or surface water resources is an important design consideration.

The saturated and unsaturated hydraulic conductivity characteristics of the subsoils beneath the disposal cell have been evaluated; Attachment 3 presents this evaluation in detail. Figure 3.15 of Attachment 3 provides a cross section of the stratigraphic units underlying the Burro Canyon disposal site. The foundation material consists of low-permeability carbonaceous shale and mudstone of the lowest unit of the Dakota Sandstone and interbedded mudstones, siltstones, and sandstones of the Burro Canyon Formation. These materials are capable of accepting tailings drainage without creating a perched saturated surface in the foundation soils. The unsaturated zone is approximately $50 \mathrm{ft}(15 \mathrm{~m})$ thick below the disposal cell. The average hydraulic conductivity of the Dakota Sandstone is $4 \times 10^{-1}$ feet per day (ft/day) $\left(1 \times 10^{-4}\right.$ centimeters per second [cm/s]), and the average horizontal hydraulic conductivity of the Burro Canyon mudstones is $6 \times 10^{-3} \mathrm{ft} / \mathrm{day}\left(2 \times 10^{-6} \mathrm{~cm} / \mathrm{s}\right)$. The average hydraulic conductivity of the uppermost aquifer (upper sandstone unit of the Burro Canyon Formation) is $4 \times 10^{-2} \mathrm{ft} / \mathrm{day}\left(1 \times 10^{-5} \mathrm{~cm} / \mathrm{s}\right)$ and is comparable to the overlying mudstone.

\subsection{DESIGN FEATURES}

The principal design features of the disposal cell at the Burro Canyon disposal site are described below. These features will ensure compliance and do not rely on active maintenance to ensure adequate long-term performance. Additional details and specifications of the conceptual design are provided in Attachment 1 of this remedial action plan (RAP).

The disposal cell will hoid approximately 621,000 cubic yards $\left(\mathrm{yd}^{3}\right)(475,000$ cubic meters $\left[\mathrm{m}^{3} \mathrm{l}\right)$ of contaminated material. It will cover an area approximately $610 \mathrm{ft}(190 \mathrm{~m})$ wide and $900 \mathrm{ft}(280 \mathrm{~m})$ long along the southwest face of the mesa (Figure 2.1). The height of the cell will range from $30 \mathrm{ft}(9 \mathrm{~m})$ to $50 \mathrm{ft}(15 \mathrm{~m})$ above the existing ground surface. The lowpermeability claystones and mudstones of the Burro Canyon Formation will be excavated to prepare the base of the cell for placement of the contaminated materials. The excavated mudstone/claystone will provide an impermeable layer from the base of the pit to approximately 7 to $39 \mathrm{ft}(2.0$ to $12 \mathrm{~m})$ up the side wall to form a continuous saucer-shaped bottom and side liner. These natural low-permeability mudstones and claystones will prevent seepage from the cell entering the sandstone stringers in the Dakota Sandstone and then leaving the site or developing surface expressions. The estimated conductivity through the cover is expected to be approximately $10^{-7} \mathrm{~cm} / \mathrm{s}$ or less. Some excavated materials will be used as fill along the embankment sides and for various 


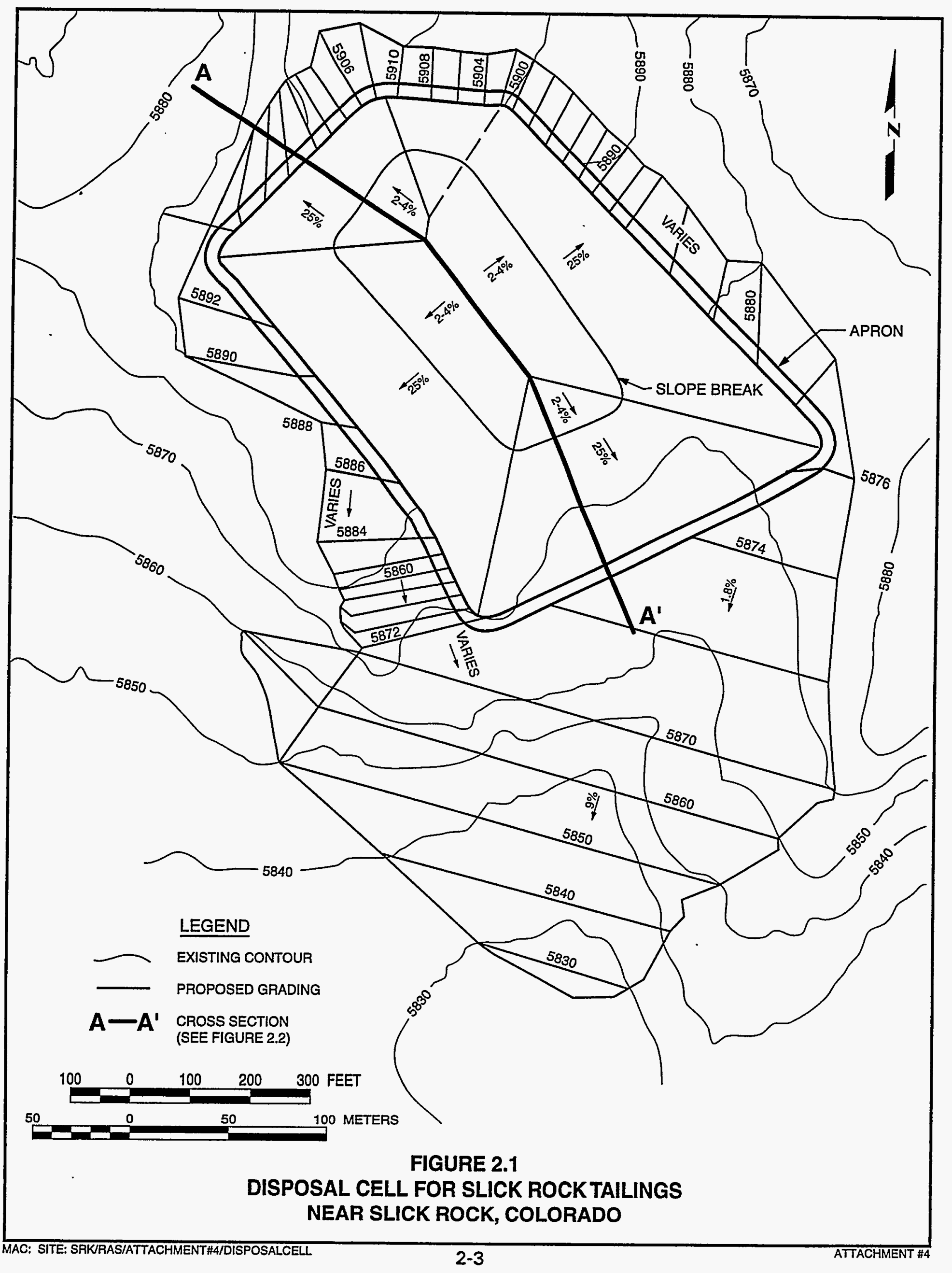


portions of the cover. If any excavated material is not used during disposal cell construction, it will remain on the site.

The completed disposal cell will occupy an area of 12 acres (ac) ( 4.9 hectares [ha]). A buffer area of 32 ac (13 ha) will bring the total to 44 ac (18 ha) removed from future use. The DOE will be responsible for scheduled long-term surveillance of the disposal area.

\subsubsection{Disposal cell cover components}

The disposal cell cover will have a riprap surface layer and additional components below the rock. Figure $\mathbf{2 . 2}$ is a diagrammatic cross section through the disposal cell. A more detailed schematic of the cover is shown in Attachment 1, Drawings Nos. SRK-DS-10-0335 and SRK-DS-10-0336.

The design for the disposal embankment cover consists of the following layers, descending from the top:

- Erosion protection layer. A layer of riprap $(8$ to 12 inches [200 to $300 \mathrm{~mm}$ ] thick) will prevent erosion of the disposal cell by surface water runoff.

- Bedding layer. A 6-inch (150- $\mathrm{mm})$-thick sand/gravel bedding layer will prevent displacement of large-diameter rock, protect the underlying frost protection layer from erosion, and drain water laterally.

- Frost protection layer. A 1.5-ft $(0.45-\mathrm{m})$-thick frost protection layer, consisting of fine-grained soil with some sand, will protect the radon/infiltration barrier from the effects of frost.

- Radon barrier layer. A 2-ft (0.6-m)-thick sandy clay radon barrier will inhibit radon emanation and water infiltration through the underlying contaminated material.

The material properties of and quantities available for the cover materials have been adequately defined in a manner that generally conforms with the applicable provisions of the standard review plan (NRC, 1985). In addition, the performance of the cover system has been evaluated using both state-of-the-art techniques and standard engineering methods. The results show the cover will remain effective for a time period that complies with the final EPA standard for long-term performance (40 CFR §192.02).

\subsubsection{Transient drainage and control of construction water}

Transient drainage of excess moisture from the tailings could result in subsurface drainage. The tailings consist of sand and poorly graded sand with silt. The tailings have a saturated hydraulic conductivity of approximately 140 $\mathrm{ft} /$ day $\left(4.9 \times 10^{-2} \mathrm{~cm} / \mathrm{s}\right)$, which is characteristic of a clean, free-draining sand (Freeze and Cherry, 1979). As a result, the tailings will have a low moisture 


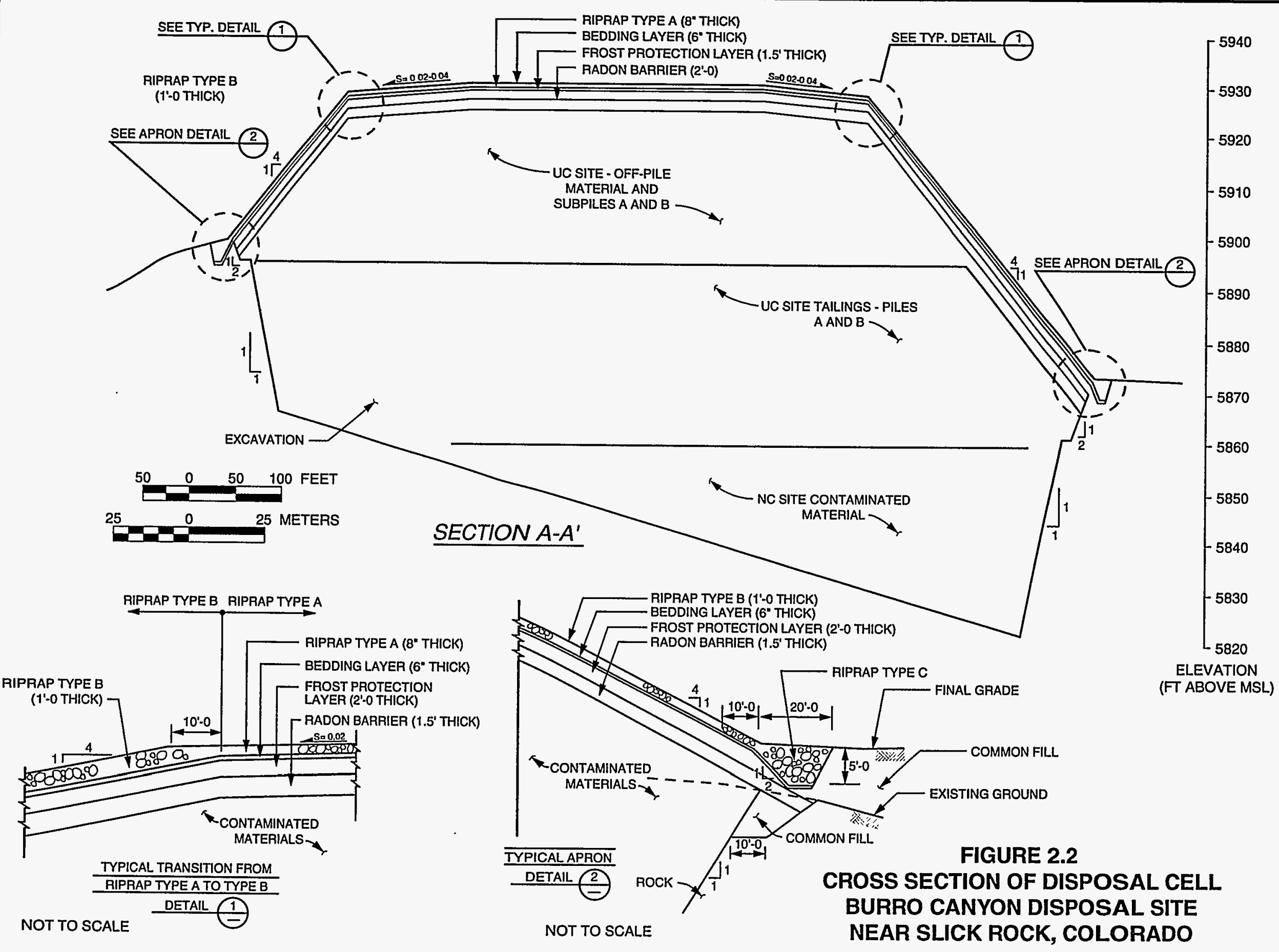


content when they are placed in the disposal cell. Moisture will be added to contaminated materials only to meet environmental dust control requirements. Stand pipes will be installed at the toe of the disposal cell to drain any accumulating water, using sump pumps, during remedial action. A minimum of one piezometer will be installed in the Dakota Sandstone near the toe of the disposal cell to check for the lateral movement of tailings pore fluid. Monitoring details will be provided in the long-term surveillance plan.

An investigation (water balance calculation) was conducted to assess whether contaminated fluid could leach from the disposal cell through the thin sandstone layers of the Dakota Sandstone and form seeps where the layers outcrop at the base of the small mesa. The results of this investigation are documented in Appendix C to Attachment 3 (Calculation No. SRK-09-94-12-01-00). The disposal cell is designed to take advantage of the low-permeability foundation materials. Excavated mudstone and claystone will provide an impermeable layer for a "liner effect," from the base of the pit to a height of 7 to $39 \mathrm{ft}(2.0$ to $12 \mathrm{~m}$ ) up the sidewall. At the site, a geologist will verify the final excavation depth and height of the impermeable layer before tailings placement. Based on the depth of excavation, the results of the water balance, and other factors such as the in situ moisture content of the contaminated materials, the maximum height of the saturated zone will not exceed the height of the natural liner effect.

\subsubsection{Subsidence}

Because mining may take place beneath the Burro Canyon site in the future, the potential exists for subsidence of the foundation soil of the disposal cell footprint. The potential effect on the stability of the disposal cell due to subsidence was assessed in Technical Assistance Contractor (TAC) Calculation No. SRK-04-90-03-03-00 (see appendix to Attachment 2). Previous mining practices in the area and conservative assumptions for analysis indicate future uranium and vanadium mining of the Upper Salt Wash Formation would not adversely affect the long-term stability of the disposal cell at Burro Canyon.

\subsubsection{Disposal cell longevity}

To ensure long-term performance, natural, stable materials are proposed for constructing the Burro Canyon disposal cell. Materials for the rock erosion protection layer have been selected, based on durability, suitability, and size, that will perform adequately over the design life of the disposal cell. The compacted radon barrier material will be protected from erosion by the overlying cover components. 


\subsection{DISPOSAL AND CONTROL OF RADIOACTIVE MATERIALS AND NONRADIOACTIVE CONTAMINANTS}

The final EPA standards in Subparts $A$ and C of 40 CFR Part 192 require information and assessments to demonstrate that RRM disposal complies with ground water protection and performance standards. The required information and assessments can be categorized as follows: the ground water protection standard (Section 3.1), a performance assessment (Section 3.4), a closure performance standard (Section 3.5), and a monitoring and corrective action program (Sections 3.6 and 3.7). The purpose of the ground water protection and performance standards is to establish the minimum acceptable performance of the disposal and control of RRM, so as to prevent or control future releases of hazardous constituents. The performance assessment confirms the adequacy of the disposal cell and describes corrective action that may be necessary if the disposal cell does not perform adequately (NRC, 1989). The following sections detail the four components of these ground water protection and performance standards.

\section{$3.1 \quad$ GROUND WATER PROTECTION STANDARD}

The Burro Canyon disposal cell is designed to control radioactive materials and nonradioactive contaminants as required by the final EPA ground water protection standards in 40 CFR $\$ 192.02(a)(3)$. The proposed ground water protection compliance strategy applies supplemental standards for limited use ground water. Protection of human health and the environment will be achieved because the uppermost aquifer has low yield lless than $150 \mathrm{gpd}\left[6.6 \times 10^{-3}\right.$ $\mathrm{L} / \mathrm{s}]$ ), as demonstrated by on-site aquifer performance tests. No known potable supply wells exist within the uppermost aquifer in a 2-mi (3-km) radius of the disposal site. The uppermost aquifer is hydrogeologically isolated from underlying saturated units by thick (50- to 65-ft [15- to 20-m]) mudstone units and by significant upward vertical hydraulic gradients. Section 3.2 provides a narrative supplemental standard.

The ground water protection standard has three components: 1) a list of hazardous constituents, 2) a corresponding list of concentration limits for the constituents, and 3) a point of compliance (POC) (NRC, 1989). The DOE has identified hazardous constituents in the tailings pore fluids that were measured in lysimeter samples and in shallow alluvial ground water at the processing sites. For this narrative supplemental standard application, no concentration limits or POCs have been established for the identified potentially hazardous constituents because the uppermost aquifer at the Burro Canyon disposal site meets the insufficient-yield criteria of limited use ground water, as defined in 40 CFR \$192.11(e) of the final EPA ground water standards (60 FR 2854). There is no historic or current beneficial use of ground water in the upper sandstone unit of the Burro Canyon Formation. As a result, defining concentration limits and a POC would not further protect human health and the environment (Section 3.1.2). Section 3.2.2 demonstrates that the remedial action is as close as reasonable to meeting the otherwise applicable standard. 


\subsubsection{Hazardous constituents}

Hazardous constituents at the Burro Canyon disposal site were identified from characterization of the tailings materials. Attachment 3 describes the uranium recovery process and evaluates ground water quality data.

Hazardous constituents potentially of concern at the Burro Canyon site were determined, based on two criteria: 1) they must be present in or reasonably expected to be present in, or derived from the RRM to be stabilized at the disposal site; and 2) they must be constituents listed in the final EPA ground water protection standards (60 FR 2854).

Eight inorganic hazardous constituents, for which maximum concentration limits (MCL) have been established, are related to uranium processing activities; their average concentrations or activities exceeded laboratory method detection limits in the lysimeter pore fluid samples from the NC or UC sites. These constituents are arsenic, cadmium, lead, molybdenum, net gross alpha, nitrate, selenium, and uranium. Six additional hazardous constituents, for which MCLs have not been established, exceeded the laboratory method detection limits. These constituents are antimony, copper, thallium, tin, vanadium, and zinc. Table 3.1 lists the hazardous constituents identified at the Slick Rock processing sites.

The ground water at the Slick Rock processing sites was screened for organic hazardous constituents. One organic screening ground water sample was collected from a DOE monitor well at the NC processing site and another was collected from a DOE monitor well at the UC processing site. Organic hazardous constituents were not detected in the monitor well sample collected from the UC processing site. Two organic compounds were detected in the NC ground water sample; however, the concentrations of the detected organic compounds are believed to be the result of laboratory contamination, rather than from the processing operations at the NC processing site (see Section 3.1.6 of Attachment 3).

The DOE has evaluated the potential effects of relocating the tailings to the Burro Canyon disposal site and has determined that, because the uppermost aquifer has a low yield (less than $150 \mathrm{gpd}\left[6.6 \times 10^{-3} \mathrm{~L} / \mathrm{s}\right]$ ) and is not a current or potential source of water, hazardous constituents from the tailings source term will not affect human health and the environment. The disposal cell design will minimize release of the potentially hazardous constituents identified in Table 3.1. Approximately 50 to $65 \mathrm{ft}(15$ to $20 \mathrm{~m})$ of low-permeability $\left(6 \times 10^{-3}\right.$ $\mathrm{ft} /$ day $\left[2 \times 10^{-6} \mathrm{~cm} / \mathrm{s}\right]$ ) interbedded mudstone and siltstone sequences will separate the base of the disposal cell from the uppermost aquifer (upper sandstone unit of the Burro Canyon Formation). The upper sandstone unit is hydrogeologically separated from the middle sandstone unit by another 60 to $70 \mathrm{ft}(18$ to $21 \mathrm{~m})$ of mudstone and by an upward vertical gradient. As a result, if any potentially hazardous constituents are released below the disposal cell foundation, the low-permeability mudstone and siltstone sequences are expected to limit further migration. Therefore, the disposal cell design should 
ensure that human health standards are met in the first potentially usable aquifer beneath the cell (the middle sandstone unit of the Burro Canyon Formation). Section 3.3 details the potential points of exposure. The uppermost aquifer is hydrogeologically isolated from the underlying water-bearing units by low-permeability mudstones and upward vertical gradients, as discussed in Attachment 3.

\subsubsection{Proposed concentration limits}

To achieve compliance with the final EPA ground water protection standards at the disposal site, the DOE proposes to apply a narrative supplemental standard based on limited use ground water due to insufficient yield in the uppermost aquifer. A narrative supplemental standard is reasonable for the Burro Canyon disposal site for the following reasons:

- The quantity of water available is less than $150 \mathrm{gpd}\left(6.6 \times 10^{-3} \mathrm{~L} / \mathrm{s}\right)(40$ CFR $\S 192.11(e)(3))$, as demonstrated by on-site aquifer performance testing.

- There is no historic or existing beneficial use of the ground water in the uppermost aquifer, due to limited yield.

- The disposal cell foundation will be separated from the uppermost aquifer by a thick layer of low-permeability mudstone (50 to $65 \mathrm{ft}$ [15 to $20 \mathrm{~m}$ ).

- Ground water in the sandstone units underlying the uppermost aquifer is protected from potential site-related contamination by the low-permeability mudstone units that inhibit the downward migration of water and steady state upward vertical hydraulic gradients in the lower and middle sandstone units of the Burro Canyon Formation.

- There is no evidence of discharge anywhere in the site vicinity; therefore, there is no point of exposure.

- The proposed remedial action at the Burro Canyon disposal site comes as close to meeting the otherwise applicable standards (40 CFR Part 192) as is reasonable under the circumstances (see Sections 2.1 and 2.2 for a discussion of disposal cell design features for protection of ground water). Section 3.3 discusses how the remedial action at the Burro Canyon disposal site will protect human health and the environment.

\subsubsection{Point of compliance}

A POC has not been established for the proposed Burro Canyon disposal site (see Section 3.1.2). 


\subsection{NARRATIVE SUPPLEMENTAL STANDARD}

The U.S. Nuclear Regulatory Commission (NRC) must consider the following four items before granting supplemental standards (NRC, 1989): 1) the criteria for applicability, 2) description of the supplemental standard, 3) demonstration that the remedial action satisfies the proposed supplemental standard, and 4) demonstration that the supplemental standard is as low as reasonable under the circumstances. Items 1, 3, and 4 are discussed in Sections 3.2.1 through 3.2.3. Item 2 is discussed in Section 3.1 .

\subsubsection{Applicability criteria}

To achieve compliance with the final EPA ground water protection standards (60 FR 2854), the DOE proposes the application of a narrative supplemental standard (Subpart C of 40 CFR Part 192) at the Burro Canyon disposal site. Ground water in the uppermost aquifer meets the definition of limited use $(40$ CFR \$192.11(e)/ based on insufficient yield and ground water use. A detailed analysis follows.

\section{Insufficient vield}

The EPA defines "sufficient yield" as a quantity of water from a well or spring sufficient to meet the long-term needs of an average family (EPA, 1986). The yield must be sustainable into the future. The EPA estimates the lowest quantity that meets this requirement is $150 \mathrm{gpd}\left(6.6 \times 10^{-3} \mathrm{~L} / \mathrm{s}\right)$. Ground water yielding less than this criterion is defined as limited use.

The ground water protection standards in 40 CFR $\$ 192.02$ (a)(3) apply to the uppermost aquifer hydraulically downgradient from the disposal unit. The upper sandstone unit of the Burro Canyon Formation is the uppermost aquifer at the Burro Canyon disposal site. Ground water in this unit occurs under unconfined conditions at constant levels and does not show seasonal fluctuations. The upper sandstone unit is not a current or potential source of drinking water because the quantity of water available is less than $150 \mathrm{gpd}\left(6.6 \times 10^{-3} \mathrm{~L} / \mathrm{s}\right)$, as evidenced by on-site aquifer performance tests. As a result, the ground water in the upper sandstone unit is limited use ground water, as defined in 40 CFR $\$ 192.11$ (e) of the EPA's final ground water standards (60 FR 2854).

Furthermore, the upper sandstone unit is hydrogeologically isolated from the underlying middle and lower sandstone units, as discussed in Section 3.2.3 of Attachment 3.

\section{Ground water use}

No known registered or private wells are actively used within the upper sandstone unit of the Burro Canyon Formation within a $2-\mathrm{mi}(3-\mathrm{km})$ radius of the Burro Canyon disposal site, because of limited yield. 
By definition, limited use ground water is not a current or potential source of drinking water. Currently, development is not planned adjacent to the Burro Canyon disposal site. Furthermore, ground water development in the vicinity of the disposal site should not increase over the next 50 years, because there is not enough water available to support development on any time scale.

3.2.2 Demonstration that remedial action satisfies the proposed supplemental standard

This section describes potential impacts of ground water use to human health and the environment. There are no historic or existing beneficial uses of ground water in the upper sandstone unit of the Burro Canyon Formation, based on the applicability criteria discussed in Section 3.2.1.

Human health and the environment will be protected for the following reasons:

- The quantity of water available is less than $150 \mathrm{gpd}\left(6.6 \times 10^{-3} \mathrm{~L} / \mathrm{s}\right)$ (40 CFR $\$ 192.11(\mathrm{e})(3)$ ), preventing future ground water development and use.

- Ground water in the uppermost aquifer beneath the Burro Canyon disposal site is not a current or potential source of drinking water.

- The disposal cell foundation will be separated from the uppermost aquifer by 50 to $65 \mathrm{ft}(15$ to $20 \mathrm{~m})$ of low-permeability mudstone.

- The first potentially usable aquifer beneath the disposal site, the middle sandstone unit, will meet human health standards because the aquifer is separated from the disposal cell by over $100 \mathrm{ft}(30 \mathrm{~m})$ of mudstone (including the upper and middle mudstone units of the Burro Canyon Formation, collectively). Also, steady-state upward vertical hydraulic gradients in the middle and lower sandstone units will inhibit downward migration of water.

- There is no point of exposure downgradient of the disposal site. Details are provided in Section 3.3.

\subsubsection{As low as reasonable under the circumstances}

The disposal cell design meets the as low as reasonable under the circumstances criterion. The design features, described in Section 2.2, will ensure that human health and the environment are protected. Active maintenance will not be required to ensure long-term performance. The proposed disposal embankment cover will use natural, stable materials to prevent surface erosion, provide protection against freezing and thawing, and inhibit radon emanation and seepage by incorporating design features that are as close to meeting the otherwise applicable standards as are reasonable under the circumstances. 


\subsection{POINT OF EXPOSURE}

Pursuant to 40 CFR Part 192 (60 FR 2854), this section assesses the potential for human and environmental exposure and concludes that the probability of exposure is low enough to prevent adverse impacts from ground water contamination. For this discussion, points of exposure can be divided into two categories: 1) surface expressions where water enters the uppermost aquifer as precipitation and outflows as surficially exposed drainage, and 2) subsurface drainage.

\section{Surface points of exposure}

The upper sandstone unit is recharged by infiltration of water from the surface outcrop upgradient of the site. Sandstone beds outcrop along the east limb of the Disappointment syncline and intercept tributaries to the Nicholas Wash drainage system. Ground water movement in the upper sandstone unit parallels the axis of the Disappointment syncline and eventually dissipates (discharges) into the Burro Canyon Formation southeast of the disposal site (Figure 3.1). The Burro Canyon Formation has a grade of approximately 3 percent. The Joe Davis Canyon is about $1 \mathrm{mi}(2 \mathrm{~km})$ south of the disposal site. In cross section (Figure 3.2), the upper sandstone unit of the Burro Canyon Formation is present only as a cap at the top of Joe Davis Canyon. Any potential seepage into Joe Davis Canyon from the Burro Canyon Formation is expected to come from the middle and/or lower Burro Canyon sandstone units. Furthermore, based on the direction of ground water movement, the Joe Davis Canyon is crossgradient from the Burro Canyon disposal cell. Therefore, any potential leachate from the disposal cell would not reach Joe Davis Canyon.

Additional potential points of exposure include two thin sandstone layers of the Dakota Sandstone that outcrop at the base of the disposal cell mesa within 200 to $300 \mathrm{ft}(60$ to $90 \mathrm{~m})$ of the toe of the disposal cell. As the Dakota Sandstone is incised during disposal cell construction, the lateral migration of contaminated pore fluid through relatively permeable sandstone layers is a potential concern. An investigation was conducted to assess whether contaminated fluid could leach from the disposal cell through the thin sandstone layers of the Dakota Sandstone and form seeps where the layers outcrop at the base of the small mesa (Appendix C to Attachment 3, Calculation No. SRK-09-94-12-01-00). Data collected from the Burro Canyon disposal site, laboratory tests, and measurements reported in the literature were used in this seepage calculation. Details of this investigation are provided in Calculation No. SRK-09-94-12-01-00 and are summarized below:

- Given that the sand tailings are very dry (saturation level is less than 20 percent) and little added water is required to meet either compaction or dust control requirements, almost no water is available to cause lateral or vertical seepage. 


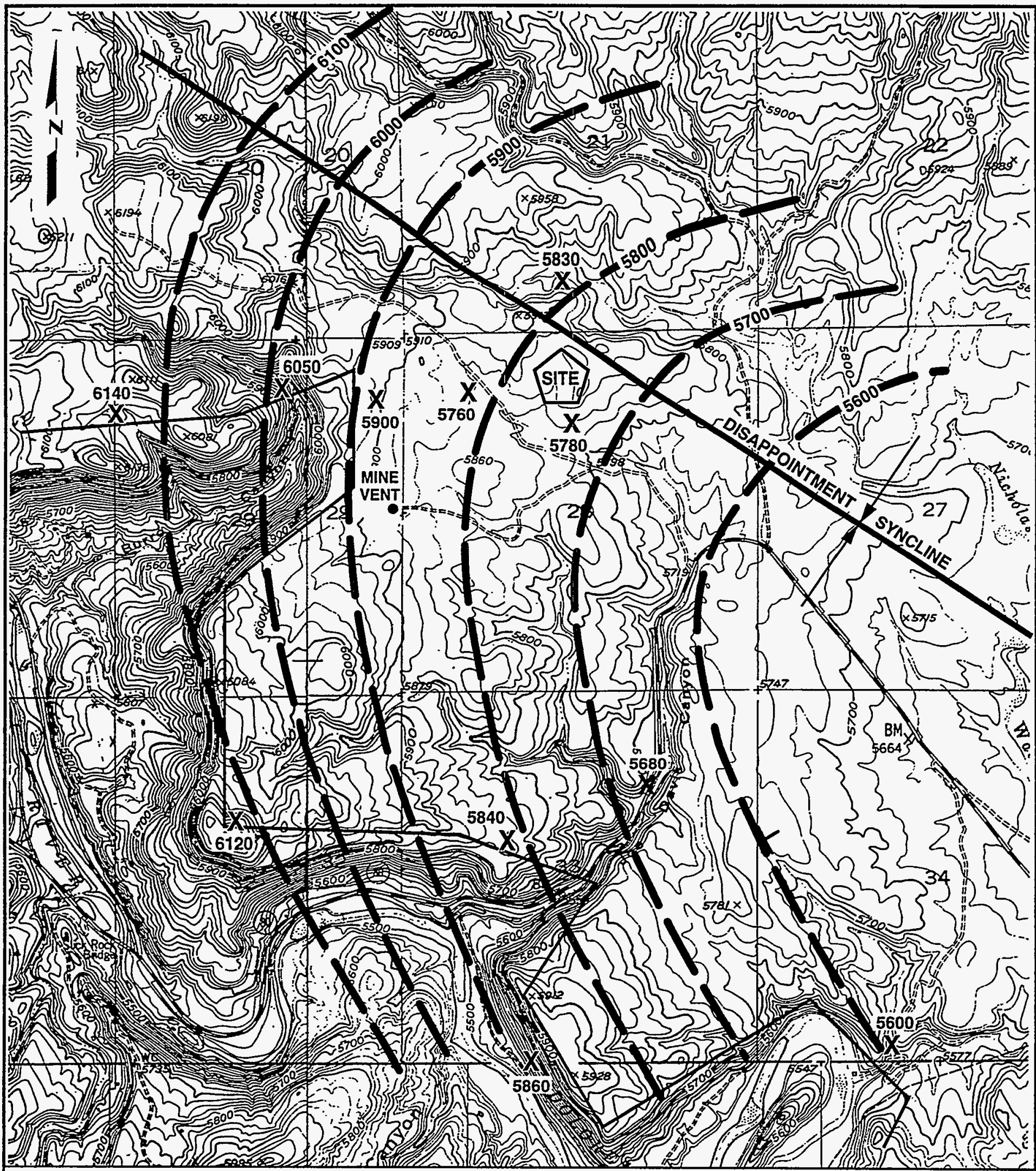

REF: ELEVATION OF STRATA TAKEN FROM SHAWE et al., 1968.

NOTE: CONTOUR APPROXIMATES CENTER OF 20-TO 30-FOOT THICK

2000 SANDSTONE UNIT.

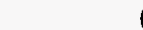

2000 FEET 500 
NOTE: PORTION OF SECTION B-B' SHOWN BELOW ONLOCATIONMAP.
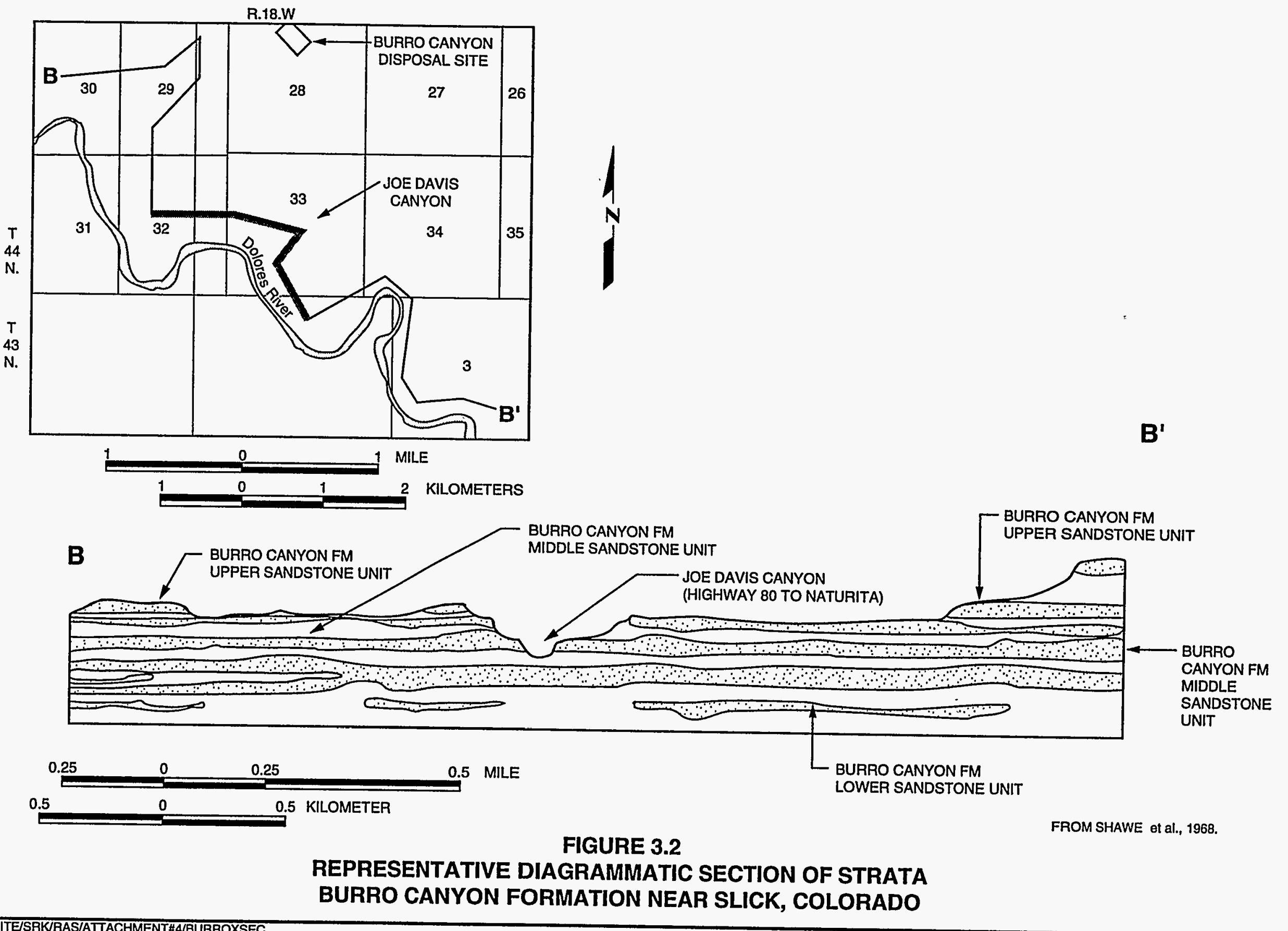
- The disposal cell design calls for excavating approximately 7 to $39 \mathrm{ft}(2.0$ to $12 \mathrm{~m}$ ) into the claystones and mudstones at the base of the Dakota Sandstone and Burro Canyon upper mudstone unit. These natural foundation materials will cut off any potential pathways of seepage and create a "liner effect."

- The excavated mudstone/claystone of the Burro Canyon Formation will provide an impermeable layer from the base of the pit to approximately 7 to $39 \mathrm{ft}(2.0$ to $12 \mathrm{~m})$ up the side wall, effectively forming a continuous saucer-shaped bottom and side liner. The natural low-permeability of these mudstone and claystone materials will further mitigate any potential that a saturation front could move into the sandstone stringers of the Dakota Sandstone.

This investigation demonstrates that the relatively small volume of leachate from the dry sand tailings will not create seeps at the mesa base at the Burro Canyon disposal site.

\section{Subsurface points of exposure}

Subsurface drainage could result from transient drainage of excess moisture from the tailings. The tailings at the Slick Rock sites consist of sand and poorly graded sand with silt. The tailings' saturated hydraulic conductivity is approximately $1.40 \mathrm{ft} /$ day $\left(4.9 \times 10^{-2} \mathrm{~cm} / \mathrm{s}\right)$, which is characteristic of a clean, free-draining sand (Freeze and Cherry, 1979). As a result, the tailings will have a low moisture content when they are placed in the disposal cell. This low moisture content of the RRM, coupled with a $1.5-\mathrm{ft}(0.45-\mathrm{m})$ thick radon barrier, will inhibit radon emanation and water seepage through the underlying contaminated material.

Approximately 50 to $65 \mathrm{ft}(15$ to $20 \mathrm{~m})$ of low-permeability $\left(6 \times 10^{-3} \mathrm{ft} / \mathrm{day}\right.$ $\left.\left[2 \times 10^{-6} \mathrm{~cm} / \mathrm{s}\right]\right)$ interbedded mudstone and siltstone sequences will separate the base of the disposal cell from the upper sandstone unit of the Burro Canyon Formation. Ground water in lithologic units underlying the uppermost aquifer also is protected from potential water seepage from the disposal cell by hydrogeologic isolation, which is provided by 1) the low-permeability Burro Canyon mudstone units that inhibit the downward migration of water, and 2) upward vertical hydraulic gradients in the lower and middle sandstone units of the Burro Canyon Formation.

\subsection{PERFORMANCE ASSESSMENT}

The DOE is required to demonstrate that the performance of the disposal cell will comply with the final EPA ground water protection standards in (40 CFR $\$ 192.02$ (a)(3) (60 FR 2854). To achieve compliance, the DOE proposes to apply supplemental standards, because the uppermost aquifer is not a current or potential source of drinking water due to limited yield. 
Aquifer performance testing has been conducted at the Burro Canyon disposal site to assess the hydraulic properties and amount of interconnection between the saturated units of the Burro Canyon Formation. The results of these and other site-specific hydrogeologic investigations (described in Attachment 3) demonstrate that ground water is protected from potential site-related contamination in the upper sandstone unit of the Burro Canyon Formation (uppermost aquifer) and in the underlying sandstone units. Hydrogeologic isolation is provided by the low-permeability mudstone units above and below the uppermost aquifer and by upward vertical hydraulic gradients in the middle and lower sandstone units of the Burro Canyon Formation.

\subsection{CLOSURE PERFORMANCE DEMONSTRATION}

The DOE has demonstrated that the proposed RAP at the disposal site will comply with Subpart A of 40 CFR Part 192 of the final ground water protection standards (60 FR 2854). The disposal cell will minimize the release of hazardous constituents to ground water and surface water and radon emissions to the atmosphere to the extent necessary to protect human health and the environment (40 CFR \$192.02(a)(4)). Natural, stable materials have been proposed for use in the construction of the disposal cell to ensure long-term performance (see Section 2.2.1). The DOE also has demonstrated that design features necessary for compliance with the ground water protection standards minimize the need for further disposal site maintenance. Because sustainable amounts of ground water are not available from the upper sandstone unit, no existing or potential users are in the area.

\subsection{GROUND WATER MONITORING PROGRAM}

Pursuant to 40 CFR $\$ 192.02$ (a)(4)(b) (60 FR 2854), this section addresses a ground water monitoring plan to be carried out during and after the remedial action period. The DOE has determined that proposing concentration limits and monitoring a POC at the Burro Canyon disposal site would not further protect human health and the environment for the reasons listed in Section 3.1.2. Section 3.3 assesses the potential for human health and environmental exposure, determining that the probability of exposure will be low enough to prevent adverse impacts from ground water contamination. Points of exposure have been divided into two categories: 1) surface expressions where the source of recharge is precipitation and discharge is surficially exposed drainage, and 2) subsurface drainage. Ground water monitoring is not proposed for the Burro Canyon disposal site because it would not be effective (insufficient yield in the uppermost aquifer precludes future use of this ground water). The only point of exposure with the potential to affect human health or the environment would be surface seepage at the base of the disposal cell mesa. Stand pipes will be installed at the toe of the disposal cell to drain any accumulating water, using sump pumps, during remedial action construction. In lieu of ground water monitoring, DOE will conduct long-term surveillance monitoring by conducting inspections to locate surface expressions of seepage at and in the vicinity of the Burro Canyon disposal site. The DOE will monitor the lateral movement of 
tailings pore fluid by installing a minimum of one piezometer in the sandstone layers (Kd1 and Kd2) of the Dakota Sandstone adjacent to the toe of the disposal cell. These visual inspections will include looking for physical evidence of mineralization, phreatophyte vegetation, and the presence of saturated zones at sandstone outcrops. Monitoring details will be provided in the long-term surveillance plan.

\subsection{CORRECTIVE ACTION PLAN}

The DOE is required by 40 CFR $\$ 192.02$ (c) (60 FR 2854) to evaluate alternative corrective actions that could be implemented if the disposal cell monitoring program indicates the unit is not performing adequately. The EPA's standards in 40 CFR Part 192 require that if initial disposal cell performance is not in compliance with those standards, a corrective action program to restore the disposal cell to design requirements will be implemented within 18 months. The DOE will notify the NRC before implementing any significant action that may be required. If evaluative monitoring indicates corrective action is necessary, the NRC will be notified within 1 month. The DOE will prepare and submit a corrective action plan to the NRC for review and approval. A copy of this plan will be transmitted to the state of Colorado. The corrective action plan may include a monitoring program to demonstrate the effectiveness of the corrective action. The DOE will implement corrective action when NRC approval has been granted.

In preparing a corrective action plan, a risk assessment may be conducted to evaluate the potential impact of corrective action on nearby populations or the environment. If the risk assessment demonstrates no potential harm to human health and the environment, the recommended corrective action may consist of "no action" except possible continued evaluative monitoring.

The Burro Canyon disposal cell has been designed and will be constructed to perform for the mandated design life of at least 200 years, and for up to 1000 years to the extent reasonably achievable, as required in 40 CFR Part 192. The cell design incorporates many safety features and therefore should perform for the mandated design life with minimal maintenance. As designed the disposal cell is not expected to fail, because all-natural materials will be used and because the radon barrier will be adequately protected from damage. 


\subsection{CLEANUP AND CONTROL OF EXISTING CONTAMINATION}

The DOE is responsible for demonstrating that cleanup or control of existing processing-related ground water contamination at the Slick Rock sites will comply with the final EPA ground water protection standards in Subparts B and C of 40 CFR Part 192160 FR 2854).

The current level of site characterization is sufficient to address only whether the remedial action (relocation of RRM) will comply with Subpart A of the final EPA ground water protection standards (60 FR 2854). The DOE has decided that ground water cleanup (Subpart B) will be addressed under a separate DOE program, which will comply with NEPA. Additional ground water characterization may be conducted to include water quality, ground water flow, and aquifer properties. A conceptual ground water restoration strategy will be developed. The proposed surface remedial action will not preclude or interfere with any potential ground water remediation activities at the processing sites. 


\subsection{REFERENCES}

DOE (U.S. Department of Energy), 1994. Environmental Assessment of Remedial Action at the Slick Rock Uranium Mill Tailings Site, Slick Rock, Colorado, DOE/EA0339, Rev. 2, prepared by the U.S. Department of Energy, UMTRA Project Office, Albuquerque Operations Office, Albuquerque, New Mexico.

DOE (U.S. Department of Energy), 1989. Technical Approach Document, Revision II, UMTRA DOE/AL-050425.0002, prepared by the U.S. Department of Energy, UMTRA Project Office, Albuquerque Operations Office, Albuquerque, New Mexico.

EPA (U.S. Environmental Protection Agency), 1986. Guidelines for Ground-Water Classification Under the EPA Ground-Water Protection Strategy, final draft, U.S. Environmental Protection Agency, Office of Ground-Water Protection, Office of Water, Washington, D.C.

FBDU (Ford, Bacon \& Davis Utah Inc.), 1981. Engineering Assessment of Inactive Uranium Mill Tailings, Slick Rock Sites, Slick Rock, Colorado, DOE/UMT-0115, FBDU 360-07, UC 70, prepared by FBDU, Salt Lake City, Utah, for the U.S. Department of Energy, UMTRA Project Office, Albuquerque Operations Office, Albuquerque, New Mexico.

Freeze, R. A., and J. A. Cherry, 1979. Ground Water, Prentice-Hall, Inc., Englewood Cliffs, New Jersey.

NRC (U.S. Nuclear Regulatory Commission), 1989. Staff Technical Position Standard Format and Content for Documentation of Remedial Action at Title / Uranium Mill Tailings Sites, February 1989, Division of Low-Level Waste Management and Decommissioning, Office of Nuclear Safety and Safeguards, U.S. Nuclear Regulatory Commission, Washington, D.C.

NRC (U.S. Nuclear Regulatory Commission), 1985. Standard Review Plan for UMTRCA Title I Mill Tailings Remedial Action Plans, October 1985, prepared by the U.S. Nuclear Regulatory Commission, Division of Waste Management, Washington, D.C.

NRC (U.S. Nuclear Regulatory Commission), 1983. Documentation and User's Guide: UNSAT2 - Variably Saturated Flow Model, NUREG/CR-3390, U.S. Nuclear Regulatory Commission, Washington, D.C.

PNL (Pacific Northwest Laboratory), 1980. Model Assessment of Contaminant Seepage From Buried Uranium Mill Tailings, Pacific Northwest Laboratory, Richland, Washington. 
Shawe et al. (D. R. Shawe, G. C. Simmons, and N. L. Archibold), 1968. Stratigraphy of Slick Rock District and Vicinity, San Miguel and Dolores Counties, Colorado, U.S. Geological Survey Professional Paper 576-A, Washington, D.C.

\section{CODE OF FEDERAL REGULATIONS}

40 CFR Part 192, Health and Environmental Protection Standards for Uranium and Thorium Mill Tailings, U.S. Environmental Protection Agency.

\section{FEDERAL REGISTER}

60 FR 2854, Groundwater Standards for Remedial Actions at Inactive Uranium Processing Sites, Final Rule, 11 January 1995. 
NOTICE

Page(s) size did not permit electronic reproduction. Information may be purchased by the general public from the National Technical Information Service, U.S. Department of Commerce, Springfield, VA 22161 (Area Code 703-487-4650). DOE and DOE contractors may purchase information by contacting DOE's Office of Scientific and Technical Information, P.O. Box 62, Oak Ridge, TN 37831, Attn: Information Services (Area Code 423-576-8401). 